RAILWAYS AND

NATIONALISATION

IEWIN A. PRAT'T

\author{
1.ONDDN \\ THU: RNIWAY GAZETTE
}


16 
blust 


\section{RAILWAYS AND \\ NATIONALISATION}

BY

\section{EDWIN A. PRATT,}

Author of Railways and their Rates, Canals and Traders, etc.

TWO SHILLINGS AND SIXPENCE NET.

LONDON :

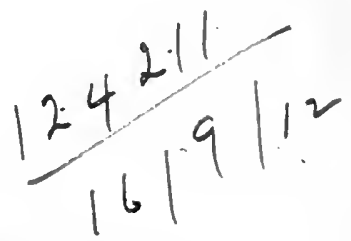

THE RAILWAY GAZETTE, QUEEN ANNE'S CHAMBERS, WESTMINSTER. 
Digitized by the Internet Archive in 2007 with funding from Microsoft Corporation 


\section{PREFATORY NOTE TO PRESENT EDITION.}

THE considerable degree of attention which has been attracted to railway problems of late, and the views held in some quarters that State ownership and operation would provide an effective solution of labour difficulties on British railways, have led me to think that a re-issue of the present work, originally published in 1908, might be of advantage to those who wish to study the question of Railway Nationalisation from the point of view of practical politics rather than from the academical standpoints favoured by debating societies, school parliaments, and the exponents of those socialistic programmes in which railway nationalisation naturally takes a leading position.

In the light of the recent attempt to bring about a general railway strike in this country, the matters dealt with in Chapter VIII., "State Railways and Labour," should, I think, be of special interest at the present moment; 
and the facts given on pages $157-172$, in reference to "A Wages Strike in Hungary," "A 'Sympathy' Strike in Holland," and "Labour $v$. Government in Victoria," might be commended to the attention of the British public in general and to that of railway nationalisation advocates in particular.*

In regard to the railway troubles in Holland, the course of events subsequent to those mentioned on page 165 has been especially significant. The fact that the Dutch Government had undertaken to revise the wages and labour conditions of the railway workers-following on the suppression, by means of troops, of the railway strike in Amsterdam in 1903-led the supporters of railway nationalisation to argue that, as a logical sequence thereto, the State ought to own and operate all the railways itself. In May, I908, the Second Chamber, by fortysix votes against thirty-nine, and after a debate extending over five sittings, rejected a resolution to the effect "that as soon as possible the measures necessary for the operation of railways

* See also the Board of Trade Reports on: "Continental Railway Investigations." [Cd. 5106 and Cd. 4878.] 
by the State should be prepared." A further Commission was, nevertheless, appointed to enquire into the alleged grievances of the railway workers, and this Commission, which has now presented its report (see The Times, August 30, I9II), has, besides dealing with these particular matters (I) rejected by ten votes against five a resolution that State management is desirable; and (2) accepted by eight votes against seven a resolution that management by a single company is desirable (that is, in preference to management by the two companies which now divide between them the operation of the State-owned and the company-owned lines, and are expected to compete actively the one with the other).

Special attention might further be directed to the extracts given on pages $427-430$ from the Report of the Royal Commission of 1865 . in reference to that Act of $\mathrm{I} 844$ which is so generally but so wrongly assumed to have established a basis for the Government purchase of the railways, should such a course be eventually. decided upon. The material fact 
to be borne in mind (although it is almost invariably ignored) is that the "terms of purchase" as laid down in the Act-namely, a sum equal to twenty-five years' purchase of the average profits for the three previous years -referred exclusively to lines constructed by virtue of Acts passed in the Session of 1844 or subsequently thereto, and not to any railways then already existing. By that time, however, the main lines of communication, to the extent of $2,320 \frac{1}{2}$ miles (see pages 429-430 for full list), had already been made; and, if the State should now decide on acquiring the railways, not one of these main lines, or indispensable sections of main lines, as operated to-day, would come within the terms and conditions laid down in the Act of 1844 .

Besides dealing both with the general question of railway nationalisation and with the policy, or the practicability, of applying it to British conditions, the book was further designed to show that State ownership and operation had either been a less conspicuous success in certain other countries than was often 
represented or, alternatively, though applicable to the countries concerned, was not therefore suitable for adoption here; while I further sought to maintain that, as I say on page 396 , "The most practical way in which, if they are allowed, the British railway companies can work out their own salvation will be in a further resort to their policy. of combinations, alliances or agreements." The last of the recommendations which I ventured to offer (see page 426) was "That Parliament, traders, and the public in general should show a more sympathetic attitude towards the railways, which have done so much to promote the national well-being; and should assist rather than retard, exploit and nullify, a rational policy which would secure the best results that could possibly follow from: railway nationalisation, while avoiding the risk of its many attendant evils and disadvantages."

The conclusion I thus sought three years ago to enforce has been abundantly confirmed by the Report of the Departmental Commission on Railway. Agreements and Amalgamations, issued in.May, 191 1 . 
The report is, in effect, not alone a complete abandonment of the traditional State policy of compulsory railway competition, apart from due regard for strictly economic considerations, but is, also, an equally complete justification of the railway policy of combinations and working agreements. The Committee have come to the "unanimous conclusion that the natural lines of development of an improved and more economical railway system lie in the direction of more perfect understandings and co-operation between the various railway companies, which must frequently, although not always, be secured by formal agreements of varying scope and completeness, amounting in some cases to working unions and amalgamations" ; and they add that they have felt it their duty " to refuse to adopt any suggestions or recommendations having for their object to make such arrangements difficult or impossible, and any which would make them so onerous to the railway companies as to deprive them of all the economic advantages of a course of action they might be able to prove would tend towards economy and 
efficiency in carrying out the objects for which they originally received their powers from Parliament."

Here we seem to be offered one practical means of meeting certain of the difficulties that arise in railway operation.

Another is foreshadowed in the undertaking given by the Government, as part of the settlement of the railway strike of August, I9I I, that they will, in I9I2, bring forward legislation providing that any increase in the cost of labour due to improvement of conditions for the staff would be a valid justification for a reasonable general increase of charges within the legal maxima, if challenged under the Act of 1894 .

The effect of this legislation will be to place the railway companies more on a level with ordinary commercial companies in passing on to the "consumer" the increased cost of production; but, though the extension of the principle to rail transport must be regarded as inevitable, one may anticipate much controversy over the question, first, as to the proportions in which the "reasonable general increase of 
charges" should be borne by traders and travellers respectively, and, next, in regard to the traders, by which classes thereof it should be borne in preference to others.

Meanwhile the Socialists are preparing to take advantage of the recent "unrest" in the railway world by starting an agitation in favour of railway nationalisation, the following announcement being made in The Times of September I, I9 I I :-

"Mr. W. C. Anderson, President of the Independent Labour Party, announced yesterday that the party is beginning a campaign in favour of railway nationalisation. It is intended that every meeting arranged by the party during the next few months shall deal with some phase of the railway question, leading up to the purchase of the railway systems of this country by the State."

In these circumstances there is the greater reason why the country should have the fullest opportunity of considering the whole subject in the light, not simply of theory or assumption, but of actual conditions at home and of accomplished facts abroad.

Euwin A. Pratt.

September, I9I I. 


\section{CONTENTS.}

CHAP.

PAGE

I. IN TRODUCTORY . . . . . . I

II. FUNDAMENTAL PRINCIPLES . . . . 5

III. STATE $v$, COMPANY OWNERSHIP . . 12

IV. REASONS FOR STATE OWNERSHIP . . . 20

v. STATE AID TO PRIVATE COMPANIES . . 40

VI. STATE RAILWAY FINANCE . . . . 60

- vil. STATE RAILWAYS AND POLITICS . . . I2I

VIII. STATE RAILWAYS AND LABOUR • . . I44

IX. STATE $\tau$. COMPANY MANAGEMENT . . . I76

X. TRADERS AND THEIR GRIEVANCES . . . 204

XI. CONTINENTAL TRANSPORT CONDITIONS 253

XII. PURCHASE TERMS AND CONDITIONS . . 294

XIII. THE QUESTION OF SAVINGS . . . . 318

XIV. THE IRISH RAILWAYS . . . . . 331

XV. STATE RAILWAYS AND NATIONAL PROSPERITY 357

XVI. BRITISH RAILWAY POSITION TO-DAY . . 370

XVII. SUMMARY AND RECOMMENDATIONS • . 421

APPENDIX : THE ROYAL COMMISSION OF

1865 . . . . . . . . 427

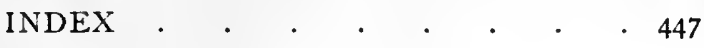





\section{RAILWAYS AND}

\section{NATIONALISATION.}

CHAPTER I.

\section{INTRODUCTORY .}

For many years past it has been usual to associate demands for the nationalisation of British railways mainly with one or other of three classes of the community: (I) Socialists, who advocate as a matter of principle that the State should control all the means of production, distribution and exchange, and seek to nationalise the railways simply because such a step would be in accord with their party propaganda and represent, as Mr. Bruce Glasier has said, "a beginning in bringing the great monopolies into the hands of the public"; (2) representatives of the Labour Party, who believe that nationalisation would lead to higher wages and shorter hours for railway workers, and tend to improve the labour position generally; and (3) certain traders, who think that, under State ownership 
of the railways, they would secure lower rates of transport and better conditions of rail transport in general. The subject has also been a popular one with lecturers, debating societies, and school parliaments; but until, at least, the General Election of 1906, and, also, the railway troubles of 1907 , it remained a matter of academic discussion rather than one likely to be brought within the domain of practical politics.

But the question has recently entered upon a somewhat new phase, because it is clear from some recent utterances of leading members of the Government that their attention is being drawn to the relations of the State to the railways, and that the possibility has been entertained of some fundamental changes being introduced in the railway position, not alone as a panacea for existing transport and economic disadvantages, but, also, as an alternative to a policy of Protection; though it is open to doubt whether any leanings in this connection towards a resort to railway nationalisation for the United Kingdom will still be favoured by responsible authorities when the whole subject has undergone thorough investigation from a practical rather than from a theoretical standpoint. Then, on February II, I908, there was a debate in the House of Commons on a resolution, proposed by Mr. G. A. Hardy, in favour of railway nationalisation; while a still later development has been 
the formation (announced in The Times of May 22, 1908) of a Railway Nationalisation Society, "for the purpose," as the Society itself says, " of educating the public mind on the subject of State ownership;" though the circular issued leaves no room for doubt that the educating process in question is to proceed exclusively along the lines of converting the public mind to the nationalisation idea. The Society in question, I might remark in passing, seems to have politicians rather than traders for its god-fathers.

To-day, therefore, the whole subject of railway nationalisation may be spoken of as being " in the air" to a greater extent, at least, than has been the case before; and it is certainly desirable that all the facts of the case should be set before the country in regard alike to the general principles of railway nationalisation, the results to which they have led elsewhere, and the practicability, or the desirability, of applying them here. It is with these particular aspects of the question I propose to deal in the chapters that follow.

There is the greater reason for the attempt here made to enlighten the public mind in regard to railway nationalisation well in advance of any possible definite action, because political developments of the day have shown that not only are attacks on " capital " much favoured in certain quarters, but that one can no longer feel any certainty that even the most momentous of measures, involving grave questions of 


\section{Railways and Nationalisation.}

finance, of equity, or of national policy, will always receive adequate discussion in the House of Commons, where debates on subjects however important may, as we find, suffer merciless curtailment to suit the exigencies of a Ministerial programme. Some recent precedents, alike in these directions and in the pressing forward of what are, avowedly, merely the beginnings of revolutionary but immature social changes-which chance and the future are to be left to perfect-invest with greater importance than ever the discussion of national questions by the nation itself, and, also, the basing of such discussion, as regards railway nationalisation at least, on that widest possible knowledge of the many and often conflicting factors involved by which alone one can hope to form a right and well-considered judgment. 


\section{CHAPTER II. \\ FUNDAMENTAL PRINCIPLES.}

By the average person the phrase " railway nationalisation" is generally employed as though it represented a single well-established principle, which everyone would understand at once, and stood in need, therefore, of no exact definition.

In effect, the phrase comprises two distinct propositions: (I) State ownership, as the result either of $(a)$ construction or $(b)$ purchase of railways; and (2) State operation thereof. A State can build railways or acquire them; but, having done either, it may prefer to hand them over to a private company to operate. In the latter case they would still be " State-owned," but they would have to be considered from a different standpoint from railways that are both Stateowned and State-operated. Thus "State-ownership" and " railway nationalisation " cannot be regarded as strictly synonymous terms, and although the latter phrase is (in this country) now generally assumed to include both of the 
factors in question, one must bear in mind that this is not necessarily the case.

These considerations are the more important because in various countries where the principle of State-ownership of railways has been-accepted (often for unavoidable reasons, as I shall show in another chapter), that of State-operation has been declined; while in certain instances this attitude has not only quite recently been affirned, but is even being carried still further, -in direct opposition to the theories of the "railway. nationalisation" party in the United Kingdom.

STATE-OWNERSHIP : COMPANY OPERATION.

The Government of the Netherlands, for example, are the actual owners of a considerable proportion of the railway mileage in Holland; but they have divided the operation thereof between two companies,-one specially formed (in I863) for "the Exploitation of the State Railways," and the other, the Holland Iron Railway Company, which owns lines of its own. A most vigorous effort has recently been made by the Liberal-Democratic Party in Holland to induce the Second Chamber of the States-General to pass a resolution expressing the view that a scheme for the operation of the State railways of the country by the Government itself, instead of by the private companies, should be prepared as soon as possible. The debate extended over 
five sittings, and resulted (May 26, 1908) in the motion being rejected by 46 votes to 39 .

In Mexico the Federal Government have, through purchases of stock, now secured control over about 7,000 miles of railway in that $\mathrm{Re}$ public. But the Government have no idea of operating the lines themselves. Instead of attempting to do so, they have (1908) brought about the formation of a private company which, under certain conditions-and subject to the supreme control the State can exercise by reason of its holding the majority of the stock-will work the whole of the railways in question.

India, again, is often pointed to by advocates of the nationalisation principle as a land where the greater part of the railways are owned by the State, and as constituting, therefore, an example for England herself to follow. But, from a Report of the Committee on Indian Railway Finance and Administration, issued in May, 1908, I find that although the State certainly does now own 22,622 miles of railway in India, it has leased 16,458 miles of this total to operating companies, and itself works only 6,164 miles, namely, the North-Western Railway, 3,569 miles; Eastern Bengal, I,27I; Oudh and Rohilkhund, I,292; Jorhat, 32. Concerning these four State-worked systems the Committee say :-

Large capital expenditure for development must be incurred on these lines in the near future, and 
direct working by the State is not without its disadvantages. The consistent policy of the Government of India for many years has been to arrange for the railways of India, while remaining State property, to be leased to companies which work them on behalf of the Government on a profitsharing basis. There is no disposition on the part of the Government to depart from this policy, which has worked satisfactorily. We would, therefore, suggest that one or more of the State lines above mentioned might be leased to companies on the basis above described.

These examples of quite recent date will suffice to show that the " nationalisation of railways" is a phrase capable of different interpretations, and requires to be clearly defined before one can rightly understand what is meant thereby. For present purposes, however, it must be assumed that when advocates of " railway nationalisation" in the United Kingdom sing the praises of "State ownership" of railways, they mean to include therein State operation as well. In fact, it would seem to be the State operation, with its possible advantages for themselves, in which the Labour Party, at least, is mainly concerned.

\section{ACTION OF LOCAL AUTHORITIES.}

Subsidiary to the question as to the active intervention of the State in the provision or the operation of railways, there is the further consideration whether or not local authorities should 
assist in the same direction. In France the departments and communes were authorised in I863-4 to give financial support to local lines; though, as I shall show later on, this authority was, in their case, abused rather than discreetly used. In Denmark a law passed in I 868 enacted that half the cost of the land required for railways built by the State should be refunded by the county councils, who were to raise the required sum by taxes imposed on fields and meadows situate within the limits of the counties through which the lines passed, and also on the inhabitants of market towns. In Norway the communes, in the case of lines owned and operated by the State, have been required to contribute to the capital cost, and to undertake all expenses connected with the acquisition of the necessary land, maintenance of fencing, etc., without receiving any direct return; while in the case of other lines (much greater in extent than those owned by the State alone) they have not only helped to raise the capital, but are joint proprietors of the railways with the State and private individuals. In Canada the municipalities have given considerable financial help to the railways. In Ireland, again, there are lines having "baronial guarantees of interest on capital," any losses sustained falling upon the localities concerned.

Here, therefore, in considering what is meant by the somewhat vague phrase, "railway na- 
tionalisation," the further question arises as to whether the action of the State, exclusively, should be invoked, or whether the co-operation of local authorities should be included as well.

\section{DIFFERENCES IN CONDITIONS.}

It must still further be kept in view that, although a resort to nationalisation, in either form or both, may, for one reason or another, have been abundantly warranted in certain other (and especially " new") countries or colonies, it does not therefore follow that the adoption of a like policy by ourselves, in our own particular circumstances and conditions, would be equally justifiable. Even, therefore, if we were convinced, first, of the soundness of the principles involved, and, secondly, of the absolute wisdom and efficiency with which they have been carried out elsewhere, there would still remain the practical question whether they are really suitable for application to-day to the United Kingdom.

Nor must advocates of the proposal omit to lay down the exact purposes which nationalisation is intended by them to serve. I shall show that different countries owning and operating State railways employ them in very different ways, according to national or colonial conditions, whether from the financial, the economic or the fiscal standpoint; sometimes, for example, looking to them for revenue; sometimes using 
them to develop industries at the cost of the taxpayer; and sometimes operating them as part of the political machinery for ensuring the efficacy of "Protection." Once more, therefore, exact definitions are necessary; and, in pointing to all that other countries have done in the matter of railway nationalisation, would-be reformers here should say definitely which of these particular countries-differing as they do so materially among themselves-they would have us take as our pattern and example. 
CHAPTER III.

\section{STATE $v$. COMPANY OWNERSHIP.}

ONE of the stock arguments advanced by the nationalisation party is that private ownership of railways is to-day found in only " two or three countries," and that England, therefore, is quite behind the times in adhering to so out-of-date a system. But no one, so far as I am aware, has yet attempted to show the real extent to which the railways of the world are owned by States and companies respectively.

To my own mind it has seemed desirable that some definite figures should be given on this particular aspect of the controversy, and, as the result of a considerable amount of research, correspondence and personal inquiry, I have compiled two tables, giving the said figures for (I) the United Kingdom and foreign countries, and (2) British Colonies, Possessions and Protectorates. It has not been possible to obtain absolutely complete returns, and, in the case of many of the countries, no more recent statistics than those for 1905 were available. But the details I give may, I think, be regarded as approximately correct, while, eren allowing for possible addi- 
tions or corrections, the excess of companyowned lines over State-owned lines, as shown in the summary at the end of the tables, is so substantial that the broad results of the comparison are not likely to be materially altered.

It should be noted that the figures relate to ownership, and not to actual operation, there being not only company-operation of Stateowned lines, but State-operation of companyowned lines. (See foot-notes to Holland, Austria, Hungary, Mexico, Peru, China and Newfoundland.) Another important consideration is that the figures represent route miles, or length of line, and not length of track, one mile of line having two, three, four or more sets of metals still counting as only one mile. This method of reckoning is to the disadvantage of the United Kingdom, where sections of railway having up to nineteen separate tracks lying side by side are to be found (see foot-note to United Kingdom), while in a large proportion of foreign countries and British Colonies, the lines, except in the immediate neighbourhood of towns, are mainly single track.

The tables are as follows :-

\section{UNITED KINGDOM aND FOREIGN COUNTRIES.}

Country.

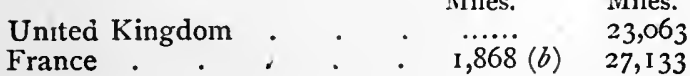

RAILWAYS OWNED BY State. Companies. Miles. Miles. 


\section{Country.}

German Empire :

Prussia-Hesse

Alsace-Lorraine Bavaria

Saxony

Würtemberg

Baden

Mecklenburg

Oldenburg (c)

Belgium .

Holland .

Russia in Europe (e)

Finland . Asia.

Norway.

Sweden

Denmark

Switzerland

Portugal .

Spain

Italy

Austria

Hungary .

Bulgaria

Servia

Roumania

Turkey in Europe

Egypt

Greece

Algeria

Tunis

United States

Mexico

Argentine Republic

Brazil

Uruguay

Chile

Peru

Bolivia.

Cuba

Honduras

China

RAILWAYS OWNED BY STATE.

Miles.

Companies.

Miles.

$$
\begin{aligned}
& 2 \text { I, } 130 \\
& \text { I,067 } \\
& 3,968 \\
& \text { 2,019 } \\
& \text { I, } 219 \\
& \text { I,036 } \\
& \text { I, } 092 \\
& 505 \\
& 2,5 \text { I } 4 \\
& \text { I, I07 (d) } \\
& 19,726 \\
& 5,216 \\
& \text { I, } 885 \\
& \text { I,354 }(f) \\
& 2,605 \\
& 1,137 \\
& \text { I, } 488 \text { (i) } \\
& 540 \\
& \text { 8,2 } 1 \text { I } 6(j) \\
& 5,158 \\
& 4,828 \\
& 736 \\
& 336 \\
& \text { I,968 } \\
& \text { I, } 434 \\
& \text {...... } \\
& \text {....... } \\
& \text {...... } \\
& \text {...... } \\
& \text { …... } \\
& \text { I,72 I } \\
& 4,294 \\
& \text {...... } \\
& \text { I,592 } \\
& 918(q) \\
& \text { I6 }(r) \\
& \text { 1, } 197 \\
& 17 \\
& 715 \\
& 3 \\
& \text { I } 31 \\
& \text { I9 } \\
& 43 \\
& 330 \\
& 992 \\
& 12,657 \\
& 168 \\
& 219(g) \\
& 5,095(h) \\
& 855 \\
& \text { I, } 103 \\
& 866 \\
& 8,961 \\
& \text { I,956 (k) } \\
& 7,8 \mathrm{I} 8(l) \\
& 6,448(m) \\
& 235 \\
& 49 \\
& \text { I } 7 \\
& \text { I, } 238 \\
& 830(n) \\
& 1,940 \\
& 428 \\
& \text { 2I8, IOI }(o) \\
& 13,905(p) \\
& \text { I I, } 047 \\
& \text { 6,299 } \\
& \text { I, } 210 \\
& \text { I, } 525 \\
& 242 \\
& 378(s) \\
& \text { I, } 500 \\
& 673(t) \\
& 3,027(u)
\end{aligned}
$$


Country.

RAILWAYS OWNED BY State. Companies.

\begin{tabular}{|c|c|c|c|c|c|}
\hline Japan & ' & - & - & $\begin{array}{l}\text { Miles. } \\
4,572(v)\end{array}$ & $\begin{array}{r}\text { Miles. } \\
442\end{array}$ \\
\hline Siam . & . & . & . & 356 & 39 \\
\hline Nicaragua & . & . & . & $171(w)$ & ....... \\
\hline Guatemala & . & . & . & $\ldots \ldots$ & 4151 \\
\hline & tals & • & - & - 108,577 & 362,620 \\
\hline
\end{tabular}

\section{NOTES.}

(a) These figures are for 1906 . The track mileage at the same date was as follows:-Ist track, 23,063 miles; 2nd, 12,934; 3rd, I,363; 4th, I,O9I ; 5th, I86; 6th, II I ; 7th, 47 ; 8 th, 29 ; 9 th, 17 ; 1oth, IO ; I I th, 6 ; I 2 th, 4 ; 1 3 th, 3 ; I 4 th to I 9 th, I mile each ; total length of track, 38,872 miles; length of sidings (reduced to single track), 14,032 miles; total length (including sidings), 52,902 miles.

(b) Purchased by State, owing mainly to the financial embarrassment of a group of small companies which had constructed the lines. Bill passed through both Houses, 1908, for purchase of Western of France railway by the State.

(c) Totals for German Empire : State-owned lines, 3I,430 miles ; lines owned by 76 companies (as shown by statistics issued by the Reichs-Eisenbahn-Amt), 2,469 miles, though the figures in the table account for only 2,125. One of these private lines, the Pfalzbahn, will be incorporated in the State system of Bavaria on January 1, 1909.

(d) Operated by two private companies, which pay the State a rent for the use of the lines.

(e) Exclusive of Finland.

$(f)$ The purely State lines have a length of 313 miles: but the State also operates I,04I miles of lines owned jointly by itself, communes, and private individuals.

(g) The private railways in Norway have all been subsidised by the State, and only one of them pays a dividend on ordinary shares.

(h) Includes I,7 I 5 miles of narrow-gauge lines.

(i) Originally consțructed by private companies. Purchased by State as result of Referendum in 1898. Other sections also to be taken over.

(j) The Italian railway system was constructed partly by 
the Government and partly by companies, to whom concessions had been granted, though the State afterwards acquired possession of the chief lines. In 1885 the administration of all the railways in Italy was left to private enterprise; but in I 905 the State assumed administration of its own lines, and resolved on nationalisation of others. In this instance the figure 8,2 I 6 represents mileage worked by the State (June 30, I907), viz.: Owned by State, 7,784 miles; belonging entirely or in part to private companies or foreign administrations, 318 ; lines temporarily worked by the State, I 14 miles.

(k) Secondary lines. Not to be nationalised.

(l) Includes 2,784 miles operated by the State railways administration. Since these returns were made the Ferdinands-Nordbahn, 819 miles, has been added to the State system. Lines of five other companies, with total of about I,860 miles, are also to be acquired by the Government.

(m) Includes 4,855 miles operated by the State railways administration.

(n) Figures for 1904 .

(o) This total is for June 30,1905 , and covers "single track railway mileage." The aggregate mileage, including tracks of all kinds, for which substantially complete returns had then been received by the Interstate Commerce Commission, was $306,796^{\circ} 74$ miles, classified as follows :-Single track, 216,973.61 miles (less therefore, than the known total); second track, 17,056.30 miles; third, 1,609.63; fourth, $1,215^{\circ} 53$; yard track and sidings, $69,941^{\circ} 67$ miles. The railway corporations included in the returns number 2,167 , and of these 1,169 are classed as "operating roads."

$(p)$ Created and operated by companies. In 1907 the Federal Government who, through purchases of stock, already controlled 3,633 miles, obtained control also over the Mexican Central (2,818 miles) and various small lines, in order to check the designs of foreign financiers. Their total was thus increased to 7,585 miles, the operation of which has now been transferred to a new (Mexican) company, formed under Government auspices.

(q) Figures for 1908. Though State-owned, these lines are operated by an English Company, the Peruvian Corpora tion, to whom they have been leased for a long term of years.

(r) Leased to the Peruvian Government.

(s) Figures for 1906. Include 304 miles owned and 
operated by an English company, the Antofagasta (Chile) and Bolivia Railway Company, Ltd.

( $t$ ) Imperial Railways of North China. These were begun as a private enterprise, but difficulties were experienced in the raising of capital. The scheme was then taken up and completed by $\mathrm{Li}$ Hung Chang as a Government undertaking ; though the system was constructed under the supervision of British engineers, and is operated by them under Chinese control.

(u) Built by foreign syndicates employing British, German, Russian, Belgian, American, Japanese, and Chinese capital.

(v) Figures for 1908. Include 2,806 miles of companies' lines purchased by the Japanese Government under the nationalisation scheme of 1906.

(w) Leased to a company for 35 per cent. of gross earnings.

$(x)$ Originally constructed by Government. Transferred to a company on their undertaking to carry out certain extensions.

British Colonies, Possessions and Protectorates.

Colony, \&c.

Canada

Newfoundland

New South Wales

Victoria

South Australia

Western Australia

Oueensland . .

Tasmania

New Zealand . . . .

India $(e)$. . . .

Ceylon

Cape of Good Hope

Natal

Orange River Colony \& Transvaal

Rhodesia.

British Central $\cdot$

British East Africa. .

Northern Nigeria . .

Southern Nigeria . .
RAILWAXS OWNED BY

Government. Companies.

Miles.

Miles.

$\mathbf{I}, 877(a) \quad$ I $8,702(b)$

$645(c) \quad 21$

$3,28 \mathrm{I}$

$8 \mathrm{I}$

3,380

I,892 (d)

1,605

3, I I 4

462

2,407

25,990

562

2,987

$797(f)$

I,685 (h)

I, 440

50

3,989

403

$50(g)$

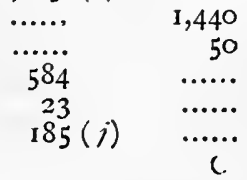


Colony, \&c.

Gold Coast

Sierra Leone

Federated Malay States.

Straits Settlements

Jamaica .

Barbadoes

Trinidad .

British Guiana

Mauritius

Cyprus

Malta
RAILIVAYS OWNED BY

Government. Companies Miles. Miles.

I 68

227

396

I 5

185

8 I

......

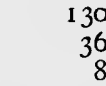

52,722
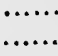

IO

25

95

36

Totals

\section{NOTES.}

(a) Figures for I906. Total made up thus : Inter-Colonial Railway, 1,478 miles; Prince Edward Island Railway, 26I ; Temiskaming and Northern Ontario Railway (a provincial Government line), 138.

(b) Miles of double track in Canada (Government and Companies' lines), 838. Railway lines, 194.

(c) Leased to a company, which is to work and develop the property, bearing loss or taking profit. . In I905-6 expenditure exceeded revenue by $£ 26,700$.

(d) Including 146 miles in the Northern Territory.

(e) These figures, which do not include foreign lines, are for 1907 . The total length of railways open in India at the end of that year was 30,053 miles, classified as follows: State lines, 22,53 I miles; Native State lines, 3,459 miles; assisted and unassisted companies, 3,052 miles ; guaranteed companies, 937 miles ; foreign lines, 74 miles.

$(f)$. Figures for I906. Natal Government also own 88 miles of railway in the Orange River Colony, and (by arrangement with the Intercolonial Council) operate a further 88 miles there.

(g) Owned by Natal-Zululand Railway Company, but operated by the Natal Government on a percentage basis.

(h) Acquired by the Imperial Government on the occupation of the new colonies. One part of the Orange Free State railways had been constructed by the previous Government 
out of revenue, and was therefore taken over without payment. The lines of the Netherlands Railway Company in the Transvaal were seized by right of conquest on the occupation of the Transvaal, on the ground that the company had taken an active part in the war on behalf of the South African Republic ; but the debenture-holders were paid out by the Imperial Government.

(i) Figures for 1907. Lines owned as follows :- Mashonaland Railway Company, 547 miles; Rhodesia Railways, Limited, 884; Rhodes' Trust, 9 . The Rhodesia Railways, Limited, also own 112 miles of line in Cape Colony, and 394 miles in the Bechuanaland Protectorate.

$(j)$ Figures for 1906.

\section{SUMMARY.}

COMPANY-OWNED RALLWAYS :

United Kingdom and foreign countries 362,620

Colonies, Possessions, \&c. $\quad \ldots \quad \ldots \quad \quad 25,928$

Miles.

STATE OR GOVERNMENT-OWNED :

Foreign Countries $\quad \ldots \quad \ldots \quad \ldots \quad 108,522$

Colonies, Possessions, etc. $\quad \ldots \quad \ldots \quad 52,722$

388,548

61,244

EXCESS OF COMPANY-OWNED OVER STATEOWNED

Estimated total of world's railways * $\quad \ldots \quad \ldots \quad 562,436$ $\begin{array}{llllll}\text { Included in above figures } & \ldots & \ldots & \ldots & \ldots & 549,792\end{array}$

Mileage not accounted for $\quad \ldots \quad \ldots \quad \ldots \quad \ldots \quad \ldots \quad 12,644$

Percentage of company-owned to world's total $\quad . . \quad$. $69^{\cdot 1}$

\begin{tabular}{lllr}
$" \quad$ "State-owned to world's total... & $\ldots$ & $28 \cdot 7$ \\
$" \quad$ "mileage not accounted for & $\ldots$ & $\ldots$ & $2 \cdot 2$ \\
& & & $100^{\circ} 0$ \\
\hline
\end{tabular}

Proportion of company-owned to State-owned ... 2.4 to 1

* As given in the "Archiv fiir Eisenbahnwesen." 


\section{CHAPTER IV.}

\section{REASONS FOR STATE OWNERSHIP.}

I come next to the important considerationgenerally overlooked by railway nationalisation advocates - as to the reasons which have led in other countries to an adoption of the principle of State-ownership of railways, with or without State operation. We are constantly being told of what has been done elsewhere; but is there any real similarity between the conditions of these other countries and our own? Have we ourselves been warranted in maintaining company-ownership instead of doing the same as these other lands have done? Have they, further, always resorted to State railways from a deliberate conviction that that is the better system, or have they not, rather, often been forced to adopt this expedient because, in their particular circumstances, they had no alternative?

\section{GERMANY .}

To begin with Germany, where the railway nationalisation principle has attained its highest and most successful development, the policy of State purchase of company-owned lines, initiated 
by Prince Bismarck, was due to various causes. Military considerations are assumed to have been paramount. Situated as Prussia was, geographically, and in view of European political conditions in general, it was thought in the highest degree desirable, in the interests of that kingdom-if not also of the prospective future Empire-that there should be lines of railway which, though not necessarily remunerative from a commercial standpoint, would allow of a rapid concentration or distribution of troops; and, for the same reason, it was no less needful that the State should be able to command, also, the use of all the main lines of existing railway. There were, however, other considerations besides; and in this connection the Financial Times of February 20, I908, says :-

Prussian railway history, which yet remains to be written, also shows how the investor may fare at the hands of a State with designs on his property. It is generally accepted that Prussia took over its railways for military purposes, but strategic considerations appear to have only been indirect factors in determining the ownership of the entire system. In brief, the development of the nationalisation idea was somewhat as follows. The Government constructed a military line, which was a success so far as its purpose was concerned. Subsequently Parliamentary sanction was refused to further extensions on the ground of cost. Then arose the brilliant idea that if all the existing railways were once vested in the Government, the consent of Parliament to authorise additional expenditure would be immaterial, provided that sufficient funds were 
available out of the secret reserves obtained from the operation of lines in being. The result of this scheme was a strangling and starving campaign under the Bismarck régime, by which traffic was diverted from the private companies, stock secretly bought on Government account, and public opinion worked up in favour of State control. These tactics naturally depreciated values, and the Government's eventual purchase was at a cheap rate. The facts here outlined are old enough to be new to the present generation, and may be commended to the notice of Home Railway stockholders.

Among the further reasons for the acquisition of the entire system by the State were the following :-

Prince Bismarck aimed at establishing a policy of Protection in Prussia; but he found it would be useless for the Government to impose hostile tariffs on foreign imports if the railway companies then operating were able to nullify those tariffs (as they showed a tendency to do) by conceding exceptionally low rates on the carriage of foreign commodities from the ports to inland centres. With State ownership of the railways, the Government would be in a position to impose such high rates as they pleased on foreign imports, and to give correspondingly low rates for the encouragement of exports, thus completing the Protection of the native producer, and converting the railways into part of the fiscal machinery of the kingdom.

Certain important financial considerations presented themselves to the Chancellor's mind. $\mathrm{He}$ 
was experiencing difficulty, from time to time, in securing from the Prussian Parliament all the supplies he wanted for the achievement of his various schemes; but, provided he could effect the nationalisation of the railway system, and thus control, not alone the operation of the lines, but also the finances thereof, he would be rendered independent of Parliamentary votes to the extent at least of the net railway profits, which, after the meeting of all claims, would thus pass into the Treasury to be made use of by the Government for general State purposes.

Prince Bismarck further aimed, on the conclusion of the Franco-German War, at the creation of an Imperial system of State Railways for the whole of the German Empire, with Prussia at the head thereof. From a transport point of view there was much to be said in favour of such a scheme. But no injustice would be done to Prince Bismarck's memory if one assumed that he was further inspired by thoughts of giving greater power and prestige to Prussia.

By this time various of the German States had Government railways of their own. In both Würtemberg and Bavaria the State had had to take over and complete certain main lines started by private companies which speedily got into financial difficulties. In Baden no capitalists could be found to.build a line from Mannheim to Heidelberg, and the State was obliged to under- 
take the enterprise itself. In Saxony the Government offered practical encouragement to railway companies by subscribing for their shares, and guaranteeing payment of interest on capital; but when, in 1845 , the construction of a line from Dresden to the Austrian frontier was found necessary, there was no prospect of such a line being built until the Government took the work in hand. In Prussia itself the dimensions of the State system, prior to complete nationalisation there, had been swollen by the Government purchase of lines from companies which had become bankrupt, especially following on the financial crisis of 1848 .

In most of the German States the prevalent system was more or less "mixed"; that is to say, some lines belonged to the Government and some to private companies. But when the States in Southern Germany realised the extent of Prince Bismarck's aspirations, they proceeded to check his idea of an "Imperial" system of railways - with Prussia at the head-by nationalising the lines in their own individual territories, thus rendering it impossible for the Prince-as they rather feared he might do-to buy up the companies operating in those territories, on his finding the Governments themselves indisposed to endorse his plans. In the result, independent systems of State railways are to be found to-day in Prussia and Hesse (combined), Bavaria, Saxony, Würtemberg, Baden and Oldenburg, 
while the Mecklenburg Friedrich-Franz Railway is also State-owned, the only lines thus far constituting an "Imperial" system in the German Empire being those in Alsace-Lorraine.

Wè have here a set of conditions, leading to State ownership and operation of railways, which cannot be paralleled by any conditions past or present in the United Kingdom; and I would submit that to this extent, at least, any reasons for a change of policy on our own part must be sought elsewhere than in the example offered by Germany.

\section{BELGIUM.}

Instigated thereto by Leopold I., Belgium began with State lines, and had 200 miles in operation by the year i 840 . But the severity of the water competition made the railways so unremunerative that when the Government proposed to build still more, the Chambers refused their assent at the time, though more State lines were built subsequently. Private companies were allowed to take up the work, and, although some of these failed, and had to be bought out by the Government, the successful ones showed so much energy, foresight and enterprise that they became powerful competitors of the State system. "Rate wars" followed, and the grave disadvantages of the dual system were abundantly manifested. But the more immediate reason for the decision, arrived at in 
I 870 , that the State should acquire control over all the main routes of railway in the kingdom, was a fear (for which there seems to have been good ground) that German speculators might buy up the private lines, or, at least, get command over them, and operate them to the advantage mainly of German interests-political and economic. Such a procedure might well have proved disastrous for Belgium; and, however much the actual operation of her railways by the State may be open to criticism, it is certain that, in the circumstances, their purchase by the State was abundantly justified.

\section{HOLLAND.}

In Holland the water competition is still more severe than in Belgium, and when, following on the recommendations of a commission appointed by him in 1836 , William I. sought to induce the States General to build a line of railway from Amsterdam to Arnheim, as the first link in a chain of rail communication with Germany, they refused, and left him to start a railway company on his own account. He lost $f 100,000$ by giving to this company a personal guarantee of payment of interest, and for many years private enterprise in railway construction had a desperate struggle for existence in Holland. In fact it became evident by I860 that State action was essential to the provision of a network of railways sufficient to safeguard Holland's economic. 
interests in regard especially to her relations with neighbouring countries. Hence the creation of a State system of railways alongside of a system created, and still being extended, by private enterprise; though, as already explained, the operation of the State lines was entrusted to companies instead of being undertaken by the Government themselves. The State has added to its own system by purchase from time to time; but there are still considerable sections of company-owned lines in Holland which the Government prefer not to take over.

\section{DENMARK.}

Private enterprise, with State guarantees of interest, started railway construction in Denmark. But the pioneer lines paid badly, and the arrangements between the companies and the Government were such that the former became disinclined to run the risk of providing railways not likely to yield a fair return. So the earliest lines got transferred to the State, and; though the offer of State subsidies, together with State purchase of shares, led other companies to construct still further lines, the plan did not always work satisfactorily. More and more of the companyowned lines thus passed over to the State, which, meanwhile, had also built on its own account. Between, however, I894 and I905 the State system in Denmark increased only from $\mathrm{I}, 0.34$ miles to $\mathrm{I}, \mathrm{I} 37$, while the private railways 
increased from 337 miles to 855. The expansion, therefore, has been with the latter rather than the former, this fact being accounted for by the large subsidies which the State gives to the companies to encourage them to build lines of their own, in preference to undertaking the work on its own account.

\section{FRANCE.}

As shown by the table given in Chapter III., the State Railways in France comprise only I,868 miles, while those belonging to companies have a total of 27,133 miles. In effect, the State system was originally a collection of more or less disconnected lines belonging to a group of impoverished if not actually bankrupt companies. Failing the possibility of making satisfactory arrangements with the great companies to take over the lines in question, it was enacted by the law of May, 1878 , that the State should acquire them and operate them itself; though such decision was spoken of in the Chamber at the time as an "acte de bienfaisance et de générosite extrême," the majority of the shareholders being "small" people who had invested most of their savings in the companies in question. There were, in addition, other lines which the Government constructed themselves because the companies declined to undertake them on the ground that there was no prospect of making them pay. 
The purchase of the Western of France Railway, agreed to (1908) by both Chambers, has been a political move designed, in part, as a "sop " to the anti-Clerical or anti-Conservative party, whose interests the deal will advance in Normandy and Brittany, where Clericalism and Conservatism are in especially strong force. One argument advanced in support of the scheme was that the State railways system would acquire outright the St. Lazare and Montparnasse stations; "but, of course," a well-informed American friend in Paris writes to me, "whatever have been put forward as the reasons, the real dominating reason is that the politicians, keen after 'soft-snaps,' wish to get possession of the line and run and control it." Purchase was opposed by trade associations, Chambers of Commerce, and other public bodies, and go per cent. of the Senate, it is said, were against it individually; but political considerations carried the day.

ITALY.

Of the railways in Italy the Board of Trade Return, "Railways (Foreign Countries and British Possessions)," issued I908, says :-

It must be borne in mind that at different periods of railway development in Italy huge sums have been spent in the construction of lines which were never expected to pay, but the existence of which was a political necessity, and without which the unification of the country could never have been accomplished. 
Under the system of concessions granted for a certain period, and not likely, as it was seen, to be renewed, the companies taking over the operation of the railways had no great interest in maintaining them in a state of complete efficiency towards the end of such period; but operation by the State has been further hampered because the railway workers; with powers of appeal to protecting deputies, refuse to submit to discipline.

\section{SIVITZERI.AND.}

The nationalisation of the Swiss railways, as the result of a referendum to the people of the country, in 1897 , was advocated at the time as a purely economic measure, having for its objects a less costly management, a lowering of the tariffs, an improvement in the condition of the staff, and the paying off of the capital; though in reality (as stated in an article published in the Tribune de Genève in May, Igo8), it was the result of a political move, a message issued by the Federal Council laying down the principle that the chief railways should be acquired by the State. The movement was further strengthened, on the one hand, by the fact that it was thought undesirable that a large proportion of the railway shares should remain in the hands of foreigners; and, on the other, by an expectation on the part of Labour that its own interests would be promoted by State ownership and operation. To 
the results of the adoption of this principle I shall allude in Chapter VI.

\section{JAPAN.}

Japan's reasons for carrying out her nationalisation scheme of 1906 were founded in part on military and in part on economic considerations. In 1905 there were in Japan 38 private companies owning and operating 3,268 miles of railway, while the State owned and operated I,46r miles. The dual system of ownership, with all its disadvantages, being thus in full force, the State resolved to take over i 7 of the chief lines belonging to the companies, and, adding them to its own, operate the whole as a State system, with what success I shall show later on.

\section{MEXICO.}

The reasons why the Federal Government of Mexico were, as mentioned in Chapter II., led to acquire so extensive a control over the railways in that Republic are explained by $\mathrm{Mr}$. Charles Edward Russell in an article published in the issue of the American magazine, Cosmopolitan, for July, 1907. The railway policy of the Mexican Government has been founded on the principle of giving concessions to private companies to build and operate the railways, though imposing on the said companies exceptionally severe regulations, in order, among 
other things, to safeguard the interests of traders and the public in general, and especially (as it would seem) to check the advent into Mexico of such abuses as had crept into railway operation in the United States of America. A very considerable network of railways was brought into existence, under these conditions, though the greater part of the capital of the different companies had been provided by American investors. A good deal of the stock was, indeed, held by certain prominent financiers, of whom $\mathrm{Mr}$. Russell goes on to say :-

The seven kings of our railroad system looked down to Mexico, and it found favour in their sight. They said it was a good thing, and they would push it along. They owned shares in many lines; they were building and planning many others. ... How fine it would be if they were to combine their interests and possess all the country !.... The Rock Island planned to carry its system southward from E1 Paso through Mexico to the Pacific coast, to the Isthmus of Panama, to regions beyond. It was a gigantic scheme and certain to have a glorious success.

Maps were made out showing how Mexico would be parcelled out by the harmonious combination of the kings. The Rockefeller lines reached here, and the Harriman lines there, and the Morgan lines over yonder, and when the combination had been effected there would be nothing left for anybody else, and nothing for the combining gentlemen to do but exploit the people and draw dividends. It was a grand conception. From time to time in the summer of 1906 the American newspapers reported its cheery progress. Everything was going well indeed; the interests were being 
brought together, the necessary controls were being secured, and in a few months the combination would be perfected and fully launched to do the Mexicans good and run their affairs for them.

But it seems that these very clever gentlemen had reckoned without another who was cleverer still, and that was Porfirio Diaz, President of the Mexican Republic. While they were elaborating their schemes with more or less publicity, the President had taken measures of defence in secret. In ways so carefully concealed, Mr. Russell says, that the "seven Kings" never heard of the matter, the President "had been buying stocks. Emissaries had moved noiselessly around France, Belgium, Germany, England and the United States, picking up what they could find;" and they picked up so much that early in December, 1906, it was announced that "there would be no consolidation of the Rockefeller, Morgan and Harriman interests in Mexico because the Mexican Government held a majority of the stock in each of the railroads these gentlemen thought they owned."

\section{BRAZIL.}

In Brazil the company owning and operating the West of Minas Railway, one of the first constructed there, drifted into financial difficulties, and eventually became bankrupt. They put up their lines to auction in 1903 and the Federal Government were the purchasers; but, although 
at present the railway is being worked by the Government, it will eventually be leased to a company.

BRITISH COLONIES.

In regard to British Colonies, Possessions and Protectorates, it will have been noticed from the table given under this heading in Chapter III. that the proportion of Government-owned lines is more than double that of the company-owned lines. But this fact is in no way surprising, inasmuch as in new colonies, where population and capital were originally alike limited, and railways were wanted even more for the purpose of opening up country to future settlement than for the supply of existing wants, the provision of transport facilities might well devolve upon the responsible Governments, rather than be undertaken by companies operating mainly on commercial lines, and in the expectation of getting a fair return, not unduly postponed, on their investments.

From this point of view I consider that adoption of the principle of State-ownership of railways may be not only abundantly warranted but practically unavoidable in Colonies and countries of the type here in question; and, to this extent, while reserving criticism on the further material detail of State operation, I am prepared frankly to admit that sweeping assertions in respect to railway nationalisation in general should not be 
made either on one side or the other, each country or Colony being, rather, regarded from the standpoint of its own particular conditions and circumstances.

\section{Australia.}

In Australia railway construction was begun both in New South Wales and in Victoria by companies; but in each instance private enterprise broke down (in New South Wales because the railway workers caught the gold fever and went off to the diggings), and in each Colony the Government were compelled to take over the uncompleted enterprises - with this result, among others : that thenceforward it was generally considered that so costly a business as the provision of railways must necessarily be left to Governments, which could raise capital more easily than companies, and need not be so anxious in regard to financial results. 'There was the consideration, again, that New South Wales, Victoria, and Queensland, especially, could not hope for full development until they had lines of railway crossing the chains of mountains that rise to heights of 3,000 or 4,000 feet a short distance from the coastal fringe, the railways being wanted to open up to settlement the plains on the other side.

Pioneer work of this kind, mainly in the interests of colonial expansion, but absolutely essential thereto, seemed to devolve much more 
upon the Colonial Governments than upon either colonial or British investors, and one cannot wonder that, in the first instance, at least, it was mainly left to the former to undertake. Later on, as the Colonies advanced in population and prosperity, the financial difficulties in the way of private enterprise would have been less acute. But by that time there were political and labour considerations which, even to the extent of creating very grave abuses, favoured both State construction and State operation of the railways; and, although the abuses have since been greatly modified, the joint principle in question has still been maintained. In the circumstances, however, it is difficult to see in what way the course adopted by Australia, under conditions so very different from our own, can possibly be offered as an example for the Mother Country.

\section{INDIA.}

In India, again, railway construction was begun by private companies under Government guarantees of payment of interest on capital ; but for many years (as mentioned in the " Report of the Committee on Indian Railway Finance and Administration "), "the earnings of the companies fell short of the interest guaranteed, and the deficit was a charge on the revenues of India." If only for this reason it is not surprising that the Government of India should have preferred to take the railways in hand them- 
selves; though, as already shown, they are now more than ever disposed to transfer the actual operation of them to companies, and to encourage the latter to raise capital on their own account to facilitate further railway expansion.

\section{SOUTH AFRICA.}

In South Africa State ownership of the railways by the Colonial Governments was brought about partly owing to the financial difficulties experienced, or likely to be experienced, by private companies (especially in carrying railway lines over vast stretches of unsettled country in order to link up the different Colonies or States), and partly because the said Governments, in the comparative absence of industries and enterprises which could be taxed, looked to the railways as a source of revenue.

To illustrate the conditions of railway pioneering in South Africa, I might mention that the first railway constructed there was a line only two miles in length connecting the harbour and the town of Durban. The company which built it could not, at the start, afford more than two locomotives; and when these broke down simultaneously the officials had to resort to the expedient of employing a gang of natives to push the wagons along on the rails. The financial resources of the company were, in fact, so limited that the staff occasionally had to accept, in lieu of hard cash, orders on tradesmen for groceries 
and other goods, or else await the return of the company's debt-collector with, possibly, sufficient funds to pay them their wages. After a time the company were able to extend their lines from a length of two miles to ten. But thereupon the Natal Government either concluded that this would be a slow process of providing the colony-to say nothing of the African Continent-with railways, or, alternatively, they thought that if there were money in the enterprise they might as well have it for colonial purposes. In any case, they began to construct railways on their own account, and the little line on which the natives used to push was taken over, to become the nucleus of what is now the considerable network of railways owned and operated by the Natal Government.

Of the railways in Cape Colony, Mr. J. W. Jagger says in the "South African Railway Magazine " for December, 1907 :-

In this colony the first lines, i.e., those to Wynberg and Wellington, were built by private enterprise, the Government, however, rendering some assistance by way of guarantee of interest, and, at the same time, taking sub-guarantees from the various districts, which arrangement was not satisfactory. In 1873 Government took over the lines; otherwise there is no doubt railways would not have been greatly extended in the Cape Colony for some years after that . . . . The railways never paid full interest until 1887 , when the traffic to the gold-fields brought prospenity. In this country we have not consciously adopted State 
ownership and management. It has been thrust upon us owing to the want of private enterprise. Had the State not taken it up, even to-day, hundreds of miles of line now in existence would not have been built, and the development of the country could not have been pushed ahead . . . The State has invested thirty millions of borrowed money in our railways, and any deficiency incurred is a first charge on the taxpayer, whether he can meet his own obligations or not.

\section{HOME CONDITIONS.}

Speaking generally, and admitting the possibility of a few exceptions, the reasons-political, military, fiscal, economic, and more especially financial-which have led, or have even, in many instances, forced other countries to adopt the principle of State ownership, are such as would not apply to the very different conditions of the United Kingdom, where railways have not yet been converted into part of the political machinery of the land; where, in our island home, the same military considerations do not arise as on the Continent; where railways are operated independently of fiscal conditions; where we have a teeming population, and few or no districts now requiring to be "opened up "; and where, until certain parties in the State began to make their persistent attacks on "capital," there has been no suggestion of any difficulty on the part of private enterprise in raising all the money wanted for either the building or the adequate extension of our railway system. 
CHAPTER V.

\section{STATE AID TO PRIVATE COMPANIES.}

Without always going to the length-voluntarily or necessarily-of building or acquiring railways in the name of the State, the Governments of many different countries have rendered important assistance to private companies in order to encourage and facilitate the provision by them of lines where such Governments might otherwise have had to take upon themselves the full responsibility of creating adequate transport facilities. This practice may be regarded as an alternative to actual nationalisation, and sometimes it has been only a possible, if not even a recognised, preliminary thereto; but so far has it prevailed throughout the world that there is hardly any country outside Great Britain (and exclusive of Ireland) in which, where railways have been built at all by private companies, practical help in some shape or form has not been given either by the State or by the local governing authorities.

Here, once more, we meet with conditions which are invariably ignored by nationalisation advocates who compare British with foreign railways, and seek to draw therefrom conclusions 
unfavourable to the former. I have already briefly indicated one or two instances in which State aid has been given to railway companies abroad; but this aspect of the question requires to be examined in somewhat greater detail.

\section{FRANCE.}

It is in France that the principle of State aid to railway companies has undergone the fullest development. In the early days of railway history the French Chambers had so little faith in the new means of transport that when, in I838, the Government brought forward a scheme for the building and operation of seven great trunk lines by the State, they refused their assent. It was, in fact, left for Englishmen to take up the task of railway pioneering in France. Following on the refusal in question, Mr. (afterwards Sir) Edward Blount, an English banker settled in Paris, undertook to raise money in England for the construction of a line between Paris and Rouen, if the Government would grant him a concession. The Government promised that, if he would raise one-third $(£ 600,000)$ of the required capital in France, and another third in England, they would give him the concession and advance to him the remainder of the capital at three per cent. interest. So, with Mr. Thomas Brassey as the contractor, and a gang of British navvies as workers, the 
line was made, and, when it was ready, an Englishman was appointed as locomotive superintendent, and fifty English drivers in the service of the London and North-IVestern Railway Company were, by arrangement with that company, appointed to take charge of the locomotives.

The principle of State aid, thus introduced into France, underwent a further development when, following on the financial troubles of 1839 , the Government agreed with a company which had obtained a concession for a line between Paris and Orleans to guarantee payment of interest on its capital, four per cent. to be paid to the State in respect to any advances thus made. With a State guarantee of interest, the company naturally found it easier to induce the otherwise reluctant French peasant to invest his savings in their enterprise.

But, even under these conditions, railway construction seemed likely to be very slow in a country where many lines were required, and in I 842 a law was passed to facilitate the construction of nine main lines of railway in France under the following conditions:-The State was to acquire the necessary land, level the ground and execute all earthworks, build bridges and stations, etc., while the companies were to lay down the permanent way, provide rolling stock, and operate the lines for the term of their concession, at the end of which period the railways 
would revert to the State, the rolling stock, etc., provided by the companies being taken over at a valuation. There was a further financial crisis in 1847 , when the Government again came to the help of the companies, and conferred on them additional advantages, even annulling various obligations which were pressing somewhat heavily upon them.

In view of the controversies of to-day, the fact may be recalled that the Republican Government of 1847 seriously considered the question of acquiring all the railways then existing in France, and working them as a State system; but the project was abandoned in favour of a continuance of private enterprise, supplemented by increased State aid.: This, indeed, was given on such a scale that of the $£ 60$,ooo,ooo expended on the lines down to the end of 185 I the State had.itself contributed two-fifths.

Following on the amalgamation policy of $185^{2-7}$, the six great companies which then came into existence were required by the Government to. undertake, without subvention or guarantee of interest, the construction - of 1,500 miles of secondary lines. Grave financial troubles resulted from their attempts to raise the money in order to comply with this requirement (railway shares depreciating rapidly, owing to the prospect of $\mathcal{E} \mathrm{i} 60,000,000$ of new railway stock being issued in the course of a few years), and in 1859 the Government agreed with 
the companies to guarantee payment of interest in respect to these new lines, the sums paid to be, as before, advances only, bearing interest at four per cent. Subsequently very large sums were paid over to different companies in accordance with the guarantee in question.

Even State guarantee of interest, however, was not found sufficient to lead to the provision of all the lines desired, and the Government then resorted to the expedient of making direct subventions in respect to local branches which the companies did not care to touch on any other terms. In this way the Government, prior to 1863 , made a contribution of over $£ 9,000,000$ to the cost of building these particular lines, independently of the guarantee of interest on others. Still more Government grants followed, and departments and communes, also, were authorised to contribute from a quarter to half the necessary capital for building secondary lines in their districts, - a power of which they availed themselves with so much zeal and so little discretion that there was brought into existence a considerable number of lines which seemed unlikely to be able to earn enough to cover even their working expenses. It was mainly a group of these lines that the Government had to take over, in 1878 , and convert into a State system of railways.

In 1879 the Government, adopting what is known as the "Freycinet programme," resolved 


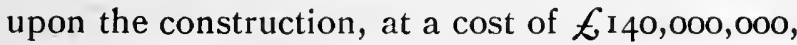
of some r8o new lines; but they soon found they had undertaken too much, and it was now their turn to seek the help of the companies. Hence the conventions of $\mathrm{I}_{8} 8_{3}$, under which, among other things, the companies assumed fresh obligations in return for a considerable extension of the "guarantee of interest" principle.

Altogether, the amount expended by successive French Governments on the construction, completion, or purchase of railway lines has been no less than $f_{192}$,ooo,ooo, of which sum only $\notin 7,000,000$ is to be put to the account of the Chemin de Fer de 1'Etat, the remainder being in respect to lines conceded to and operated by private companies. In addition, there was still owing to the State, at the end of 1907 , a sum of $\mathcal{E}_{4} 8$,000,000, of which $\ell_{34}$,000,000 was on account of advances made, and $\mathcal{E}_{14}, 000,000$ for unpaid interest on advances, under the State guarantees to the companies.

Another interesting fact which might be mentioned in connection with the French railways is that under a law passed in November, 1897, departments, municipalities and Chambers of Commerce are authorised to raise loans "for the purpose of constructing, altering, or improving any public railway station or stopping place," the amounts thus advanced being repaid, at fixed intervals within a period of not exceeding fifty years, by means of extra charges imposed on 
passenger and goods traffic moving in or out of such station, a special accisunt thereof being kept in the books of the railway administration concerned. This law applies alike to State and company-owned lines, and has already been taken advantage of in the case of various railway stations, including those at La Rochelle, Nantes and Tonnay-Charente, Nice, Bourg and Manthes.

In England not only do local authorities refrain from offering any assistance to railway companies in the building or improvement of their stations, but any material alterations made are at once taken advantage of as an excuse for raising the assessment, even though the alterations may be solely in the public interests, and not bring any extra return whatever to the railway company. This fact has, in some instances, led to railway companies having to decline to carry out station improvements they would otherwise willingly have made.

Under the French practice it would have been possible for the local authorities or for the London Chamber of Commerce to raise a loan and advance money to the London, Brighton and South Coast Railway Company towards the expenditure of considerably over $\notin \mathrm{I}, 000,000$ by that company on the reconstruction of their Victoria Station, and on the street widenings and public improvements connected therewith, the loan being repaid out of extra fares and charges which the company would be authorised to 
impose on passenger and goods traffic going into or coming out of the station. Under the British practice the company themselves pay the very substantial costs incurred, and get no contribution from the local authorities even in respect to the widening of a portion of Buckingham Palace Road and the approaches to and the roads over the Eccleston and Elizabeth bridges, although if these improvements had been carried out under a County Council tramway scheme the cost would have fallen in part upon the local rates.

\section{GUARANTEE OF INTEREST.}

The principle of a State guarantec of railway companies' interest is one that has been adopted in various other countries besides France. It helped to smooth the path of several German railway companies before the advent of nationalisation. It was resorted to by the Belgian Government when some of the pioneer railway companies there got into financial difficulties. It encouraged private companies in Denmark to persevere in their efforts. In Brazil the Government, in granting concessions to private companies, originally guaranteed a percentagegenerally from five to seven per cent.--on a fixed capital outlay; but in that Republic the system was, as stated in the Board of Trade Return, "Railways (Foreign Countries and British Possessions)," " not found on the whole to work 
satisfactorily, for though some of the lines did so well as to make no call on the Government guarantee, many were constructed with the apparent intention of living upon it entirely."

\section{DENMAR K.}

The early railway companies in Denmark received State aid in various forms. In some instances the Government guaranteed interest at the rate of four per cent.; in others they subscribed to the share capital. The latter procedure subsequently led to a system under which the State gave the companies a fixed amount, generally $£ 950$ a mile, with the right to take over the lines under certain conditions; though this arrangement was not found to work well, and the State eventually bought up several of the lines which had been so constructed.

\section{I.UXEMBURG .}

In Luxemburg the companies constructing secondary and cantonal (local) railways have received from the State (by way of practical encouragement and assistance) mining concessions according to the importance and extent of the lines. One company, which has built i I 7 miles of railway, has had successively about I,494 acres of mining concessions; another, providing 25 miles, was given 350 acres of such concessions; and still another, whose line is 27 miles 
long, was awarded 380 acres. In the case of the Northern line (the Guillaume-Luxembourg), the concession for which was given in 1856 , the Government granted a subsidy towards the cost of construction.

\section{SPAIN.}

Concerning Spain the Board of Trade Return, " Railways (Foreign Countries and British Possessions)" says :-.

There are no State railways in Spain, but the State is at present assisting in the construction of a line between Betanzos and Ferrol, levelling the ground and making the bridges, while the concessionaires will lay the rails, build the stations, and finally work the lines, the amount to be thus expended, i.e., 7,193,919 pesetas (£266,441) counting as a subvention to the company. There are also other companies in receipt of subvention, amounting in all to $8,000,000$ pesetas $(£ 296,296)$, in amounts varying from 25 to 50 per cent. of the cost of building one line. A recent Act likewise guarantees 4 per cent. interest on lines with a capital of not less than 50,00o pesetas per kilometre ( 2,980 per mile) of line; but this law has not yet come into force.

In return for these subventions the State has certain advantages, and will, also, become sole proprietor of the railways at the end of 99 years from the date of the original concessions.

\section{GREECE.}

Of the position in Greece the Board of Trade Return says :-

There are in Greece no State railways, properly 
so called; that is to say, none of the railways have been either wholly or partly acquired by the State. But the State has an interest in most of the railways, in some cases a large interest, having spent considerable sums in the construction of the lines and receiving a certain share of the profits. There are thirteen lines now working and administered by companies. For all but three of these the State has incurred expenditure in the form of either loans, grants, or expropriations.

An appended table shows that the State expenditure on railways in Greece, under the three heads just mentioned, amounted at the end of I 904 to $f_{3}, 627,991$, and the direct receipts by the State from all the companies during the course of that year were $\mathcal{E} 8,06 \mathrm{I}$; though, adding indirect revenues in the form of taxes, dues, stamps, etc., the total receipts of the State from the railways in 1904 came to about $\mathcal{E}_{45}, 450$.

\section{INDIA.}

In India every company which has constructed a railway has, the Committee on Indian Railway Finance and Administration state, "received more or less assistance from the Government, varying from a guarantee of interest to a free grant of land only." The latter practice has been so general that the Committee say concerning the modern companies that "in practically every case they have been provided with land free of cost." 
CANADA.

Aid to railways in Canada has comprised: (I) Money grants by (a) the Federal Parliament, (b) Provincial Legislatures, (c) municipalities; (2) loans ; (3) Government guarantee of interest ; (4) Government issue of debentures by way of loan to railway companies; (5) Government guarantee of railway bonds; (6) direct issue of Government bonds to railways with a first mortgage on the companies' properties; (7) Imperial Government guarantee of capital; (8) share capital locally distributed; (9) land grants; (Io) release of Government loans by placing them behind other loans; (I I) composition of Government claims; (12) assumption by Government. of liabilities incurred by municipalities; direct construction by Government; (I4) combined land and money grants; (15) construction in part by Government and part by company, the latter leasing the Government-built road.

The amount of public money invested in the construction of steam railways in Canada to June 3oth, 1906, is shown by the following table, the figures for which I take from The Canada.Year Book, 1906 :-

Dominion Government Aid :-

$$
\begin{aligned}
& \text { Loans ... } \quad . . \quad \ldots \quad \$ 15,664,533 \\
& \text { Bonuses . ... ... } 182,562,95 \text { I } \\
& \text { Subscriptions to shares } \\
& \text { or bonds } \\
& \text { Paid up } \ldots . \quad \ldots . \quad \ldots \quad \ldots \quad \$ 194,188,584
\end{aligned}
$$




$$
\begin{aligned}
& \text { Brought forward } \ldots \quad \ldots \quad \ldots \quad \ldots \quad \$ 194,188,584 \\
& \text { Provincial Government All :- } \\
& \text { Loans ... } \quad \ldots \quad \ldots \quad \$ 4,648,956 \\
& \text { Bonuses } \quad \ldots \quad \ldots \quad 39,877,676 \\
& \text { Subscriptions to shares } \\
& \begin{array}{ccccc}
\text { or bonds } & \ldots & \multicolumn{3}{c}{300,000} \\
\text { Paid up } \ldots & \ldots & \ldots & \ldots & \$ 43,278,022
\end{array}
\end{aligned}
$$

\begin{tabular}{lcccc} 
Loans $\ldots$ & $\ldots$ & $\ldots$ & $\$ 4,066,854$ \\
Bonuses & $\ldots$ & $\ldots$ & $12,371,994$ \\
Subscriptions to shares \\
$\begin{array}{r}\text { or bonds } \\
\text { Paid up }\end{array}$ & $\ldots$ & $\ldots$ & $2,610,000$ & \\
$\therefore$ & $\ldots$ & $\ldots$ & $\ldots$ & $\$ 17,125,164$ \\
Total paid up & $\ldots$ & $\ldots$ & $\ldots$ & $\$ 254,591,770$ \\
\hline
\end{tabular}

The figures under the head of "Dominion Government Aid" include costs of construction of Government-owned railways (Inter-Colonial Railway and Prince Edward Island Railway). Excluding these items, the amount paid by the Dominion Government for other than Government railways, to 1906 , was $\$ 118,474,316$.

In addition to direct financial assistance, Canadian railways have been aided by extensive grants of land given, not alone for the building of their lines, but also to enable the companies to raise more capital by selling off such land to their own advantage, and especially as it increased in value, following on the construction of the railway. In the case of the Canadian Pacific Railway, which a private company undertook and completed after successive Governments had shown themselves hopelessly incompetent to accomplish the task; the terms agreed 
to included a subsidy to the company of $\$ 25,000,000$; a grant of $25,000,000$ acres of land (of which 7,000,000 acres were afterwards taken back at \$I.5o per acre); and the transfer to the company when completed of the 700 miles of line included in sections already under construction.

\section{NEWFOUNDLAND.}

Newfoundland is mainly indebted for her railway system to the late Sir Robert Gillespie Reid, a Scotsman who, after doing much important work in the building of railway bridges in the United States and Canada, proceeded to Newfoundland, and secured a contract to construct and operate for ro years a trans-insular railroad and telegraph system, in return for a grant of 5 ,ooo acres of land, in alternate sections, for each mile of railway built. The line was completed to the extent of 600 miles in 1897 . In the following year he made a further contract with the Government to operate all trunk and branch lines in the island for 50 years, paying $\$ \mathrm{I}, 000,000$ for the reversion of the whole at the end of that period, and receiving additional land concessions amounting to about 5,500,000 acres. Under a subsequent agreement the colony was given the option of recovering the railway system at the end of the 5o years by paying back the $\$ 1,000,000$ with interest and a further sum for betterments. Mr. Reid, who died in June, 
54 Railways and Nationalisation.

I908, was known as one of the largest landowners in the world.

\section{UNITED STATES.}

Pioneer railway companies in the United States of America got assistance in the form of land grants, supplemented in some instances by direct financial aid. Mr. J. M. Trout says in his book on "The Railways of Canada" that the Pacific Railways Company had grants of public lands amounting altogether to $35,000,000$ acres, in addition to which the United States Government issued $\$ 6_{3}, 616$, ooo in six per cent. currency bonds in aid of the undertaking. The Northern Pacific Company had the right to take alternate sections to the total extent of over 74,000 square miles. Very large grants of land were also made by the United States Congress to the different States in order that these, in turn, could effect a free transfer of them to the railway companies, whose finances, also, they materially assisted by direct contributions, by guarantees of interest (Alabama, for instance, guaranteed eight per cent. interest on one of her railways to the amount of $\$ 16,000$ per mile of completed and equipped railway), or in other ways. The companies were aided, also, by being exempted from taxation for a certain term of years, and by being allowed to construct the initial lines in the most primitive fashion, with a view to supplying immediate wants, the understanding being that 
betterments would follow as the traffic grew and the companies had more money.

In 1870 it was estimated that public bonds to the extent of $\$ 185,000,000$ and grants of $215,000,000$ acres of land had been given to various railroad corporations up to that time by the United States Government and municipalities.

In later years, and especially in the neighbourhood of large cities, American railway companies have had to pay heavily for the land they wanted for new lines or widenings. But the practical assistance given in the earlier days was of enormous advantage both in promoting the work of railway construction and in allowing of economical operation; and these factors in the situation have a distinct bearing on present-day transport conditions in the United States.

EXPERIENCES OF BRITISH RAILWAYS.

I have selected these examples from countries of various types, in different parts of the world, in order to illustrate the kind of help which States in general have either found it necessary, or thought it desirable, to extend to private companies undertaking the responsible and costly work of railway construction. When; from this survey, we pass on to ask what successive British Governments have done to render financial or other practical assistance to private companies 
in the construction and operation of railways in Great Britain (as distinct from Ireland) the reply is-Nothing whatever! There has been no guarantee of interest; there have been no loans, subsidies, bonuses, or free grants of land for railway purposes, by either Imperial or local authorities; there has not even been any lightening of the railway burdens and requirements in directions in which sympathetic help and encouragement could have been given without either encroaching on the public funds or making any pretence of generosity.

In Great Britain the State stood passively by whilst land-owners raised endless difficulties in the way of railway construction and practised the most shameless extortion on railway companies, from whom the uttermost farthing was wrung before they could get the land on which their lines were to be built. The State has sanctioned and encouraged a system of Parliamentary procedure, in regard to the granting of railway companies' powers, so costly that a competent authority once estimated the expenditure on this account alone at an average of $\mathcal{E}_{4}, 000$ per mile of line actually constructed. The State enforces on the companies principles of railway construction based on absolute completeness from the start-principles excellent for the public, but much more costly than the system adopted in countries where economy has been allowed at first, with betterment to follow. The 
State has fostered a competition, and has imposed restrictions, regulations and conditions in regard to safety appliances, hours of labour, unremunerative workmen's trains, etc., which, however justifiable-should that always have been really the case-have added materially to the working expenses. The State, also, itself levies on the railways $\mathscr{\ell} 350$,000 a year for passenger tax, and $£ 2,000,000$ a year for Income Tax, and tolerates the policy followed by those local authorities throughout the land to whom the railways have long been a milch cow for the purposes of local taxation, the sum total of such taxation imposed on the railway companies of the United Kingdom being now close on $£ 5,000,000$ a year.

State Control of Rates and Charges.

Not only, therefore, has there been no State aid to railway companies in Great Britain, as in other countries, but our own State policy has led to the financial obligations devolving on railway companies being greater than they should be, and greater far than the corresponding obligations resting on railway companies elsewhere. The enormous expenditure thus involved could be met only by the rates, fares and charges to be paid by users of railways built under these particular conditions. Yet even here the State has thought it understood the intricacies of rail transportation better than the railway experts, 
and, while showing little regard for investors who have found the money for building and operating the lines, thus saving the State from the trouble and financial complications that a system of Government railways might have involved, has aimed at keeping these rates, fares and charges down to the lowest possible proportions.

To this end there have been Acts of Parliament, commissions, joint committees, and departmental committees without end. Traders throughout the land have been encouraged to send in every conceivable complaint, however trivial; the railway companies, besides incurring serious dislocation of their business in attending inquiries and meeting such complaints, have been involved in an expenditure which, in the aggregate, might have allowed of the reduction of not a few of the rates complained of ; and assertions by traders having votes have carried far greater weight with politicians in office-and desirous of staying there-than the protests and explanations of companies with no votes at all.

The whole position is supremely illogical. To the average person, who views the matter without prejudice, it must appear that the railway companies have sinned less than they have been sinned against, and that State and people must accept some, at least, of the responsibility for present-day developments of past policy.

Admitting that certain of these developments 
are not only open to criticism but capable of reform, it may still be argued that a complete transfer of the railways of the United Kingdom to the State, with all the consequences such transfer would involve, should not be undertaken without the most absolute proof of the need and the desirability of so revolutionary a change. 


\section{CHAPTER VI.}

\section{STATE RAILWAY FINANCE.}

WHEN the advocates of State ownership attempt to deal with the financial results of nationalised railways, they have a twofold argument which, from their particular points of view, may be applied satisfactorily to either profits or losses. Should the railways in question show, or claim, a profit, it is said, "See what an advantage it is to the State to control all that money instead of allowing it to go into the pockets of private speculators." Should there be no profit, or a loss, their plea is, "Railways ought to be run in the interests of the community, and not with any idea of making a profit at all.",

As a rule, however, the said advocates do endeavour to show that State operation of a unified railway system is more economical, and leads to better financial results, than the company operation of different lines. Lord Brassey, for example, in speaking on railway nationalisation at the Autumn meeting of the Association of Chambers of Commerce in September, 1907, said: "In Germany and Russia, 
in Belgium, and more recently in Italy, railways have become the property of the State. The requirements of the public are fully considered; the results to the Exchequer have been satisfactory." Sir John Gorst, when advocating nationalisation in his Liverpool speech on March 7, 1908, is reported to have spoken of "the great surpluses of the German, Belgian, Swiss, and Australian State railways as proof of the financial success of national ownership;" and Mr. Chiozza Money, M.P., and others have had much to say to the same effect. I propose, by looking into the results of State railways in general, to let the reader judge whether or not their financial success really has been so great as the nationalisation party assume.

The usual way of showing a "profit" on the operation of a State railway is to set down the gross receipts and working expenditure for the year, and to represent as "profit" the difference between the former and the latter, without making any allowance for payment of interest on capital expenditure, etc.; although, when the fixed charges are added to the figures, the balance may at once be turned into a deficit. There is also a disposition to ignore other inconvenient items; to mix up the railway accounts with the national or colonial debt; and to manipulate the figures generally in such a way as to give an impression that the financial position of the State lines may be regarded with 
complete satisfaction. Examples alike of these tendencies and of unremunerative working of Government-owned lines, whether with or without an unduly favourable presentation of the accounts, are especially afforded by the railways of Australasia.

\section{NEW SOUTH WALES.}

In his "Wealth and Progress of New South Wales," for I894, Mr. T. A. Coghlan said concerning the railways of that Colony :-

The cost of the lines opened for traffic on June 30 , I895, was $£ 36,611,366$. Of this amount $£ 903,565$ has been provided out of the Consolidated Revenue of the Colony, and debentures to the amount of $E_{1,266,146}$ have been finally paid off. The socalled reduction of the railway debt is purely imaginary, seeing that the bulk of debentures retired were renewed out of fresh loans, and the sum paid from revenue to redeem loans was not furnished by railway profits.

The same authority, in his "Statistical Account of Australia and New Zealand, I903-4," said :-

In establishing the financial results of the working of the lines, it is the practice of the railway authorities to compare the net returns with the nominal rate of interest payable on the railway loans outstanding, ignoring the fact that many loans were floated below par, and that the nominal is not the actual rate of interest. A true comparison, of course, is afforded by taking the rate of interest payable on the actual sum obtained by the State 
for its outstanding loans . . . . The rate of return on capital represents the interest on the gross cost of lines. In some cases the nominal amount.of outstanding debentures is less than the actual expenditure, owing to the fact that some loans have been redeemed; but as the redemption has been effected by means of fresh loans charged to general service, or by payments from the general revenue, and not out of railway earnings, no allowance on this account can reasonably be claimed.

Then in the report of the New South Wales Government railways and tramways for the year ending June 30, I905, " the result of the year's working " in regard to the railways was given thus :-

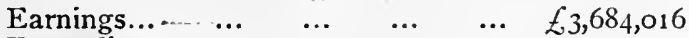

$\begin{array}{llllll}\text { Expenditure } & \ldots & \ldots & \ldots & \ldots & 2,192,147\end{array}$

Balance after paying working $\begin{array}{llllll}\operatorname{expenses} \ldots & \cdots & \cdots & \cdots & £ 1,491,869\end{array}$

To the casual observer this looked as if the said balance represented profit. But on referring to the "general remarks" in the report one finds that the interest due on the capital invested, calculated at 3.582 per cent., amounted to $\mathcal{E} 1,526,948$, or $£ 35,079$ in excess of the abovementioned balance, which thus represented a deficit. One also learns, from the same " general remarks," that on the recommendation of a Special Committee appointed by the Government a sum of $£ 600,000$ advanced by the Government about twenty-five years ago for the purchase of material and general stores had been 
64 Rallways and Nationalisation.

added to the capital account "for the first time," while the committee further recommended that a sum of $£ 456,639$ ( $£ 434,184$ for railways and $£ 22,455$ for tramways), having been defrayed from the Consolidated Revenue, and therefore not a debit against the State, should he regarded as "non-interest bearing capital.",

It was found possible to claim a real surplus for $1905-6$, for which year, accordingly, the figures were set forth thus :-

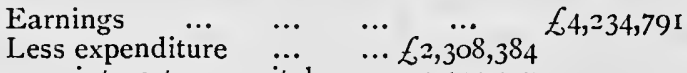

$$
\begin{aligned}
& " \text { interest on capital ... } \quad 1,541,427 \\
& \text { Surplus } \quad \ldots \quad \ldots \quad \ldots \quad \longdiv { £ 3 8 4 , 9 8 0 }
\end{aligned}
$$

In the Chief Railway Commissioner's report for I906-7 the surplus, after payment of interest on capital, is given as $\mathcal{E}_{610,955}$. The same report shows that $£ 508,7$ or of the total amount expended on construction and equipment of railways had been "paid from the Consolidated Revenue," and, it is added, " no interest is payable thereon."

Between a "balance after paying working expenses" and an actual "surplus" there is, of course, a very material difference; but while, in the former case, the "interest on capital " is not mentioned in the summary, or until the " general remarks" are reached, there is no longer any 
reluctance to give due prominence to so substantial an item when a real surplus can at last be shown. It is further obvious that the controllers of a Colonial Grovernment railway have an advantage over a private company in being able both to use public money for twenty-five years without having to regard it as " capital," and to get from the Consolidated Revenue, as "capital," substantial sums which are not to bear any interest.

Nor must one ignore the fact that there are in New South Wales a score or so of unremunerative lines on which, as the Chief Railway Commissioner's reports show, the losses in the four years, 1903-1906, after providing for working expenses and interest, amounted to $\ell^{1,393,974}$.

For an example of independent Australian opinion I turn to the Pastoralists' Review (Melbourne) for October 15,1907 , where I find the following remarks in reference to a proposal for the establishment of a Government line of steamers, the chief argument advanced in support of such project having been the alleged success of the Colonial railways :-

The fact is that not a single Government has made a success of its railways. They have always really been bankrupt, and get deeper and deeper into the mire every year, besides which in some of the States they are years behind the times. If the lines were run by private companies with no general taxpayer to draw upon, they would have been wound up years ago. The fact is that enormous 
sums have been procured from the general taxpay? to make good the deficits extending over many years, and to purcliase railway material. These have never been debited to the railway accounts as they should have been, and would be in any business undertaking. Take the New South Wales railwavs, alone, for example. Their accumulated deficit is over $\mathcal{E}^{25}$,000,000 already, and this sum gets larger every year. The railways would be hopelessly insolvent if it were not for the taxpayer keeping them solvent every year. . . Government undertakings never paid interest on cost yet, nor will they ever do so. They only exist on subsidies from the taxpayers.

\section{VICTORIA.}

When, on February 16, 1907, delivering a speech in which he made an exhaustive review of his own administration, Mr. Bent, Premier for Victoria, said concerning the railways of the Colony : " We have practically $\mathscr{E}_{40}$,000,000 loan money employed in the railways, and a few years ago we were losing $\ell_{1}$, ,oo a day on them, and the rolling stock had got almost to danger point." He took credit for the later improvements, and for reductions in freights conceded in I906; yet even the surpluses of the last few years would seem to be due to special advantages available in the case of a Government-owned Colonial railway, though impracticable in that of company-owned railways in the old world, while if, in addition to the surpluses now being claimed, one takes into account previous deficits, 
the financial results as a whole are shown in a very unsatisfactory light.

The deficits admitted in 1901-2 and 1902-3, after payment of working expenses, special expenditures, and interest charges, were $£_{197,227}$ and $\mathcal{E}_{365,254}$ respectively.

(I shall refer later on to the earlier results.) Since then the surpluses claimed, after making the same allowances, have been : $\mathcal{E}_{519}$ in 1903-4; $\notin 649$ in I904-5; $\mathcal{E}_{198,965}$ in $1905-6$; and $\mathscr{E}_{279,132}$ in 1906-7. But the report of the Railway Commissioners for the last-mentioned financial year further mentions that the " amount provided out of Consolidated Revenue for the construction, equipment, stores, etc., of the railways, and on which no interest is charged," stood on the 3 oth June, 1907, at $\ell_{13}, 849,939$, an increase during this year of $£ 91,959$, made up as follows: Amount expended under Surplus Revenue Acts and debited to sundry works of construction, etc., $\ell_{74,580}$; amount expended under appropriations and votes, and debited to sundry works of construction, etc., $\notin 17,379$. It is obvious that if interest had been allowed for in respect to these items, the financial results of the year's operations would appear in a very different light from that in which they are presented.

Then the working expenses of the Victorian railways are lightened by the omission from them of any allowance in respect to pensions and 
gratuities. Thus the Commissioners' report for 1906-7 says :-

The amounts paid in pensions and gratuities, which are not included in the working expenses, were $£, 94,926$ and $\mathcal{E}_{15}, 955$ respectively, a total of Eiro,881, as compared with $£ 92,994$ and $£ 6,643$ respectively, a total of $£ \cdot 99,637$, in the previois year.

Another material point to bear in mind is that under "An Act to further amend the law relating to the Victorian railways," passed in 1896, it was enacted (Section 14) that-

In the following cases (that is to say):-

(a) Where Parliament makes any alteration in the law which occasions any increase of expenditure by the Commissioner or any decrease of the railway's revenue; or

(b) Where Parliament or the Governor in Council directs the Commissioner to carrv out any system or matter of policy which occasions or results in any increase of expenditure by the Commissioner, or any decrease of the railway's revenue; or

(c) Where Parliament authorises the execution of any new line of railway which when vested in the Commissioner does not produce sufficient revenue to cover the interest on its cost of construction, and the expense of its maintenance-

the annual amount of the increase of expenditure or decrease of revenue or of the loss resulting from such new line of railway shall be from time to time notified in writing by the Commissioner to the Commissioners of Audit, and if certified by them, shall 
be provided by Parliament in the annual Appropriation Act and paid to the Commissioner.

In the report of the Railway Commissioners for $1905-6$ it was stated that the amounts received from the State Treasury under Section 14 of the Act of 1896 , and included in the gross revenue, were: For decrease in the revenue due to the carriage at reduced rates of agricultural products, $£_{41,787}$; of Victorian coal, $£ 5,676$; on account of enhanced cost of Victorian coals purchased during the year owing to a direction of the Governor-in-Council fixing the prices to be paid, $£ 5$, I 35 .

The Commissioners recommended, however, that in view of the improved position and prospects of the railways, the allowance to be provided by Parliament for the carriage of agricultural produce at reduced rates should, in the ensuing year, be reduced to one-half of what was actually being paid, or one quarter of the amount that might be asked for under the Act of 1896 . This further reduction was made in 1906-7, the Parliamentary allowance on the item in question being, for that year, $£_{25}$, 000. The Commissioners then announced that, owing to the continued improvement in the railway revenue, no further payments on account of the carriage of agricultural produce would be applied for from the Treasury; which I take to mean that whilst agricultural products are still being carried at unremunerative rates, the railways are 
now able to bear the loss themselves, without asking Parliament for a subsidy from the general finances of the Colony. In making their announcement, however, in their report for I go6-7, the Railway Commissioners added :-

The reductions which have been made during the last five years in these payments [i.e., payments from the Treasury], together with the reductions made during that period in the rates on agricultural produce, represent on this account alone a decrease in the net revenue of, approximately, $£$ ioo,ooo per annum.

The State Treasury allowance to the railways in 1906-7 for decrease in the revenue due to the carriage of Victorian coal at reduced rates was $f_{7,40}$; while in the same year the amount which the Treasury re-imbursed to the railways in respect to the enhanced cost of Victorian coal for locomotive purposes owing to a direction of the Governor-in-Council fixing the price to be paid for such coal was $\ell_{3}, 893$.

The amount of money either actually wasted or, presumably, proposed, at some time or other, to be wasted in Victoria on the building of unnecessary lines is shown by a table given in the report for $1906-7$ under the heading of " Capital expenditure incurred in respect of lines now closed for traffic, and surveys of lines, not constructed, on which interest is charged against the railways." Seven lines, one learns, of a total length of 46 miles, and constructed at an 
approximate capital cost of $£_{3} 87,424$, have been closed for traffic, two of these (including one 15 miles long) being lines which had been dismantled. The approximate cost of lines surveyed but not constructed is given as $\mathscr{L} 3 \mathrm{I} 6,46 \mathrm{I}$.

The following remarks made by the Victorian Railway Commissioners in their report for 1905-6 as to the disposal of the surplus for that year throw a further light on the financial conditions under which Government railways may be operated :-

It is to be regretted that the revenue of the railways for the year in excess of the working expenses and interest charges has not been made available to entirely liquidate the extraordinary liabilities appearing in our balance-sheet, amounting at $3^{\text {oth }}$

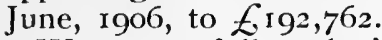

We respectfully submit and strongly recommend that the surplus revenue of the railways, that is, the revenue in excess of the working expenses and interest charges in full on the Railway Debt of the State, should be devoted

First-To the liquidation of liabilities chargeabic to revenue, thus eliminating from the balance-shes: such objectionabie items as "Deficiency in Rolling Stock, E. $54,4^{1} 3$," and " Expenditure on Renewals of way and works, and replacement of rolling stock tcmporarily charged to capital, remaining to lie. repaid out of revenue $£ .38,349$."

Second-Towards providing the funds required for such additions and improvements of existing lines and for additional rolling stock as may te sanctioned by Parliament, thus to that extent obviating the borrowing of additional money by the State for such purposes, thereby increasing the debt of the State. 
Third-Towards building up a revenue reserve fund, so that in a year or in years during which, by reason of unfavourable seasons or other causes, the net revenue of the railways is not sufficient to pay in full the interest charges on the Railway Debt of the State, the deficiency may be made good out of this Reserve Fund instead of out of the Consolidated Revenue, as in the past.

The net result of the operation of the Victorian railways is thus described in an article on "The Failure of State-Owned Railways," which appeared in the Melbourne publication, Liberty and Progress, for February 25, 1908 :-

The Victorian deficit to date is, as far as can le ascertained from the very imperfect accounts published before the present Commissioners took office, $E 7,75^{8}, 15^{2}$; and, though in the last four years the Commissioners have paid surpluses amounting to E.478,866 into the Treasury, yet as they have not charged themselves with the pensions paid duriag those four years to employés and officers of the department, which amount to $f 413,7 \mathrm{IO}$, that surplus is reduced at a stroke to $\AA_{65}, 1_{5} 6$. Moreover, I,986 persons are now ranked as being entitled to pensions or compensation, and the list, which last year entailed a charge of $\oint_{\mathrm{I}} \mathrm{I}$ I0,88I, continually increases. Indeed, since 1889 it has grown from $£ 81,284$ to $£$ I10,88I, an increase of $£ 29,597$.

In a later issue (that for April 25, 1908) the same periodical, quoting from the Victorian Railway Commissioners' “ General comparative statement for 15 years, from July I, I892, to June 30, 1907," shows that the total dead loss on the Victorian railways was not $\not .7,75^{8,152}$, as

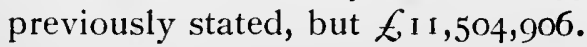




\section{QUEENSLAND.}

The figures just quoted in regard to Victoria suggest how inadequate annual reports are for the purpose of affording a comprehensive survey of a Colonial railway's finances as a whole. In dealing, therefore, with the Government railways in Queensland, I think it better to turn at once to such a comprehensive survey of them as I find in Liberty and Progress for March 25, I 908 .

Nothing, apparently, should be easier, that journal remarks, than to find out the revenue of the Queensland railways and the return they make upon the capital invested, inasmuch as the Commissioner of Railways issues an annual report which is full of information. But his details do not agree with the still fuller and more explicit account given by the RegistrarGeneral in " Annual Statistics of Queensland," while further divergencies are found in an "Official Year Book," edited by Mr. Hughes, of the Statistician's Department, and another by Mr. Thornhill Weedon, who also holds official rank as a statistician. "None of these," says the writer of the article, "agree with the others, nor does Mr. Coghlan's examination agree with any of them. None of them covers the entire ground except the Registrar-General, who annually accounts for every sixpence of the receipts and expenditure of the State, and he 
frankly acknowledges the manner in which the earlier accounts were what might be called 'cooked,' though 'favourably presented' is, perhaps, the politer term."

As an example of this tendency it is shown that in the official return of working expenses in I 868 it was not thought necessary to include under this head the salaries of the Railway Commissioner, of the engineer, or of their respective staffs.

Another important factor in the situation is that when Queensland decided to have her railways her population was very small, her credit was low, and the investment was not popular with financiers. In the result all those of her railways that were constructed before 1872 were made with money which had cost over 6 per cent. Construction began in 1865 , and the result of the first five years' working was a loss of $£ 403,266$, without taking into account the omitted salaries. For the ten years from 1870 to 1879 the figures of the various conflicting official reports leave no room for doubt that there was a loss of

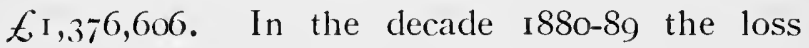
amounted to $\mathcal{L} 2,418,658$, making a total loss to that date of $\mathcal{E}_{4}, 198,530$. For the period $1890-99$ the shortage was $\mathcal{E}_{3}, 284,057$, raising the total deficit to $\mathcal{E} 7,482,587$. The writer of the article concludes :-

The end of the century gave little hope of improvement. The official Year-Book tersely says the 
total capital cost to the year I900 was $\ell_{21}$ r,495,916. The Registrar-General, however, appears to have adopted the lower figures of the Commissioner, who, in his last Report, treats a sum of $f \mathrm{I}, 418,784$ as being a suspense account. The total expended, acording to the Commisioner, is $E_{21,839,081}$ on opened lines, and $\pm 816,439$ on unopened lines, making together $\mathbb{E}_{22}, 725,520$. But the total amount charged against the railways in the statement of the public debt is $\mathcal{E}_{24}, \mathrm{I}_{44}, 3 \mathrm{O}_{5}$, and that is the sum on which the State pays interest. The magnitude of the amount, the imperfection of the accounts in earlier years, and the general desire to minimise, as far as possible, the disastrous results of governmental arrangement of an enterprise left in older countries to commercial people who unde:stand it, may be inferred from the fact that no two accounts agree, and also from the silence of the experts as to the actual yearly burden. The nat earnings and net losses are given only in percentage, excepting by the Registrar-General, and there is a difference of $\mathcal{E} 1,618,542$ between his estimate of the total cost to the year 1900 and that of tine official Year-Book. Mr. Coghlan, agreeing with neither, gives a third estimate, putting the cost at E.205,468 less than that named by the RegistrarGeneral, from whose office he must, presumablv. have obtained his infornation.

The seven years, I900-1906, added $f, 2,532,874$ to the previous deficit, thus increasing it to a total of $\mathcal{E}_{\mathrm{i}}$ o,or5,46r. These figures, however, it is explained, are only approximate, the lowest official return being accepted, even when it leaves large sums to the so-called "suspense account" of close on $E_{\mathrm{I}}, 500,000$. "The net result," the writer pertinently says, "is that up- 
wards of ten millions has been lost in a vain attempt to manage a business in which, from first to last, little more than twice that sum has been involved."

Further examination of the Queensland accounts shows that in only three out of the 45 years over which they extend has the balance available for payment of interest and all other purposes, after covering working expenses, amounted to over 4 per cent.; in seven years it has been between 3 per cent. and 4 per cent.; in ten it has ranged between I per cent. and 2 per cent.; and in six it has been less than I per cent.

\section{SOUTH AUSTRALIA.}

Thanks to what is described as a "splendid season" in the year ending June 30, 1906, the South Australian railways, on which the capital outlay has been $\mathcal{E}_{13}, 610,520$, were able to show "working results" for that year as follows :-

$$
\begin{aligned}
& \begin{array}{lllllll}
\text { Earnings } & \ldots & \ldots & \ldots & \ldots & £ 1,349,165
\end{array} \\
& \begin{array}{lllll}
\text { Expenditure } & \ldots & \ldots & \ldots & \ldots 764,385
\end{array} \\
& \text { Interest on Loans } \quad \ldots \quad \ldots \quad 474,955 \\
& \text { Surplus } \quad \ldots \quad \ldots \quad \ldots \quad \quad £_{1110,425}
\end{aligned}
$$

" Such surplus revenue should, in future," says the Railway Commissioner in his report to the Government, "be carried to a reserve account to meet deficiencies in unprofitable years and replacements as found necessary." 
But one finds once more how misleading it may be to judge of a Colonial railway on the basis of a single recent report without reference to what has gone before. Turning to the merciless critic in Liberty and Progress, I read:-

The South Australian lines, since their beginning, cost in working expenditure $\mathcal{E}_{1} \mathrm{1}, 803,079$, and in interest on the sum invested in them $£_{12}, 851,507$, a total of $£ 30,654,586$. Their yross receipts for the entire time have been $£ 29,144$, I 5 , so that the net loss has been $£ 1,5^{10}, 43^{6}$.

To this must be added the loss on the Northern Territory lines, which from their beginning to Junc 30 last amounted to $£ 939,760$. Consequently, without counting anything for the depreciation of the plant, which certainly cannot now be worth the E. $14,904,686$ expended upon it, the total loss to South Australia is nearly two and a half millions$£ 2,450,196$.

\section{TASMANIA,}

Concerning the Tasmanian railways, the Melbourne journal reproduces balance-sheets for the years 1886 , 1896 , and 1906 , and says :-

The pith of the matter is that Tasmania has expended $£ 3,927,714$ in the construction of railways which may or may not now be worth their prime cost. In thirty years these railways have earned a gross income of $\&_{3}, 678,047$, at a cost of $£_{2}, 892,886$, leaving the comparatively trivial balance of $E_{i} 78,161$ to set against the enormous interest charge of $\mathcal{E}_{3}, 112,599$, and saddling her with a net loss of $£ 2,327,43^{8}$.

For I905 the net loss on the Tasmanian rail- 
ways, after allowing for interest on capital, was $£ 75,612$, and in 1906 it stood at $£ 79,676$.

\section{WESTERN AUSTRALIA.}

The one colony in Australia which is able to show a net profit on its Government railways, not only for the past few years, but on the whole operation, is Western Australia, where the net return on total earnings from the start, in 1879 , to present date, after allowing for working expenses and interest, has been E.431,692.

But the Western Australian railways have points of interest which are especially instructive in showing the basis on which a Governmentowned system may be operated, and the special purposes it may be expected to serve, apart from affording facilities for transport.

The Commissioner of Railways in the Colony, Mr. William J. George, appears to be strongly prejudiced in favour of the idea that, even when a railway is owned by a Government, it should be operated in accordance with the ordinary principles of commercial finance, and apart altogether from questions of sentiment. The Colonial Government are free from such prejudices, with the result that there have been differences of opinion between themselves and the Railway Commissioner on the subject, more especially, of coal and water.

The Government are anxious to develop the 
Collie coal industry in Western Australia, and to this end they want to have a preference given to Collie coal for locomotive purposes on the Government railways. The railway officials, on the other hand, declare that the coal from Newcastle, New South Wales, not only produces much better results than the Collie coal, but, though costing more to buy, is cheaper to use over a considerable portion of the system because of a saving in haulage. The chief mechanical engineer reported in 1905 that "the working expenses of the Department through using Collie coal at places where Newcastle was the cheaper were increased by $£ 29,100 "$; while, taking what he calls the "equitable value" of the Collie coal for actual locomotive purposes, and comparing this with the contract price which the Government persist in paying, the Railway Commissioner calculates, in his report for 1906, that an annual bonus or subsidy of $\mathcal{E}_{16,250}$ is paid to the Collie coal industry through the expenses of the Railway Department. The matter has been placed exhaustively before the Government, and the representations made as to the inferior quality of the Collie coal compared with that from Newcastle have been fully confirmed by scientific tests; but the Government have decided that, "as a matter of policy"--that is to say, in the interests of the Colonial coal fields - the course hitherto adopted must continue. 
On the subject of water, the Railway Commissioner says, in his 1906 report :-

The Railway Department has purchased $65,536,000$ gallons of water from the Goldfields Water Supply Administration, and has paid 6s. 3d. per $\mathrm{I}$, ooo. On every calculation that can be employed the "equitable value" of this water to this department should be not more than 35 . per I, oon gallons-a price which is actually quoted to manv small consumers. The actual payment included in the accounts submitted with this report amounts to E:20,480. At the "equitable value" named above this payment would be $£ 9,830$, and the difference, E 10,650 , represents a credit to the Goldfields Water Supply Administration which may be considered as a bonus to the Scheme at the expense of the Railway Department.

We revert here to the question of principle as to whether, when a Government-owned railway is, in the interests of State or Colonial policy, compelled to operate on non-commercial and unremunerative lines, the losses it thus incurs should or should not be made good out of the general finances. I have shown that this has been provided for in the case of Victoria; but in Western Australia the burden falls on the railway itself, and it is to the credit of the Railway Commissioner there that, in the circumstances, he can show such good results as he does. But this commendably outspoken official says, in his report for 1906 :-

If the working railways have (I) to pay more for both coal and water than it is considered is the 
value equivalent; (2) the freight rates reduced considerably; (3) not. to take advantage of the wages rates as laid down in the award of the Arbitration Court; (4) to pay an ever-increasing interest bill$£ 348,467$ for $1905-6$, as against $£_{22} 2,891$ for r $901-1902 ;(5)$ the running of spur lines for the development of agriculture, but which for some time can scarcely be expected to return revenue in excess of the expenditure, and so must become, for a time at any rate, a charge on the more developed branches of the railway system, and tend to increase the ratio of working costs; it is quite evident that a surplus cannot be long maintained.

Still another suggestive item given in the same report, and further bearing on financial results, is the following :-

Payments under the Workers' Compensation Act are being heavily felt by the Department. During the year no less than $£ 4,5967 \mathrm{~s}$. 8d. was paid to employés injured, or to the representatives of employés killed during the course of their employment,

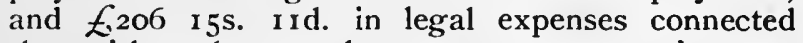
therewith, the total expenses amounting to $E_{4}, 803$ 3s. 7d.

The operation of the Act is so very comprehensive that the sum paid greatly exceeds what would be due under the Employers' Liability Act. That is to say, payment is not confined to compensating employés for injury done by defect of the Department's machinery or other negligence, but the Act requires that even where the injury is due to the neglect or default of the employé, unless absolute proof of wilful and serious misconduct can be advanced, payment must be made.

The effect is that employés are provided with a free insurance of $£ 400$ in case of death, and up to $£ 300$ in case of disablement. 


\section{NEW ZEALAND.}

The position of the railways in New Ztaland was described in somewhat glowing terms before the Viceregal Commission on Irish Railways by the Premier of the Colony, Sir Joseph Ward, and other witnesses; but there is another side of the story, and this is very well brought out in some trenchant criticisms on "New Zealand Railway Finance" by Professor James Edward L.e Rossignol, contributed by him to an American publication, Moody's Magazine, for August, 1907 .

Sir Joseph Ward "said in his evidence :"Our rates are fixed on the basis of a return of about $3 \frac{1}{2}$ per cent." But Professor Le Rossignol shows that this return of $3 \frac{1}{2}$ per cent. is merely the difference between total earnings and total expenditure for the year, and leaves out of account any payment of interest on the railway debt. He quotes as follows from Sir Joseph Ward's Railway Statement for I906 :-

The results may be summarised thus :-

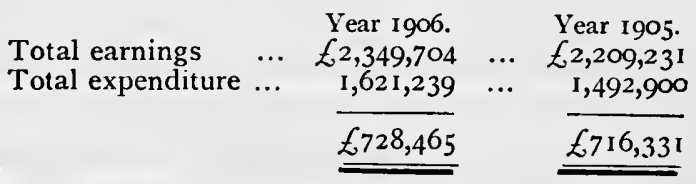

The net revenue, $f_{i} 7_{2} S, 465$, is equal to a return of $3^{.24}$ per cent. upon the capital invested in the open 
lines, and $3^{\circ} 02$ per cent. on the capital of $\mathcal{E}_{24}, 092,085$ invested in opened and unopened lines.

On this Professor Le Rossignol remarks :-

The Railway Statement, which few people read, does not state that the interest on the railway debt, estimated at the average rate of 3.75 per cent., amounted to $E .903,453$, so that the so-called " net profit on working " of $\ell_{12} 28,46_{5}$, when applied to the payment of interest, becomes a net loss of E. 174,988 , as compared with a deficit of $£ 146,377$ for the previous year.

For the year 1906-7, I may here state, the difference between gross revenue and working expenses, called "profit on working," was f8r2,II8; but, allowing the same amount of interest on the railway debt as before, namely, $£ 903,453$, the so-called profit once more becomes a deficit, of $\mathcal{E} 9 \mathrm{I}, 335$, making a total deficit for the three years of $\mathcal{E}_{412}, 63 \%$.

The Board of Trade return already referred to says in reference to the New Zealand railways: "No capital charges have been repaid out of revenue. The capital cost of the railways forms part of the National Debt of the Colony, and the whole of the profits accruing from the working of the railways of the Colony are paid into the Consolidated Revenue." From this it would appear that the item of interest on capital expenditure is conveniently omitted from the railway accounts altogether.

Professor Le Rossignol admits that from the New Zealand standpoint cheap transit is pre- 
ferred to revenue, and he quotes Mr. Henry G. Ell as having said, in a recent debate in the House: "I do not regard with alarm the fact that the railways are not paying interest by some $£ 200$,000 a year." The Professor suggests, however, that while cheap transit is, doubtless, highly beneficial to a community, "it does not seem unreasonable to demand that the users of the railways should pay at least the cost of the service. To ask the tax-payers, as such, to make up a railway deficit is," he rightly points out, " to ask many people who do not enjoy the benefits of railway transporation to pay for those who do, and is a direct encouragement to extravagance and inefficiency in the public service."

In addition to the very considerable net loss that has been sustained on the operation of the Australasian State railways as a whole, there must be reckoned the absence of that substantial sum in rates and taxes which would have been contributed to the Colonial finances had the railways been in the hands of private companies. In his book on "The Labour Movement in Australasia," Mr. Victor S. Clark estimates the further loss thus sustained at $£ 800,000$ a year.

CAPE COLONY.

How difficult it is to arrive at definite conclusions as to the financial results of the Govern- 
ment railways at the Cape is shown by the following remarks which $I$ find in the third report of a Commission appointed in 1904 by the Governor of Cape Colony to inquire into and report upon the public service there :-

No intelligible balance-sheet or profit-and-loss account appears in any of the annual reports that deal with the railway, and it would puzzle anyone but a skilled accountant to collect the necessary information from the published sources. It is true that the general manager's report gives in detail the cost of each line, and the revenue and expenditure under a variety of heads for each line and system; but the materials are not brought together in a form which readily shows whether or not the railway, as a whole, is a paying concern-whether, in other words, it would pay a dividend if it were the property of a private company. The available figures, moreover, require to be reconciled and modified . . . before they can be made the basis of any satisfactory calculation.

Criticising, from this point of view, the general manager's report for I903, the Commissioners show that, allowing for various items in respect to interest and outstanding charges, which they think should have been included, the loss on working in that year may be taken to

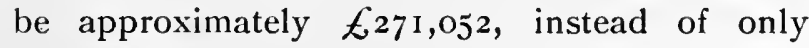
$\mathcal{E}$ I 40,669 , as calculated by the general manager; and similarly the profit on working in 1902 would be only $\mathcal{E}^{1} 3,079$, instead of $\mathcal{E}^{\prime} 3_{22,516}$. They think that the general revenue is fairly entitled, as "revenue re-imbursements," to in- 
terest on the railway floating debt, which is at present about $£ 5$, 000,00o; and they also mention the fact that "while the charges incurred in raising railway loans (including the discount on loans) have since 1883 been debited as part of the cost of construction of railways, no charge has ever been made previous to I904-5 for commission on the payment of interest or repayment of capital; and no pensions, or contributions from the general revenue to pension funds, have ever been charged to the railways. On the other hand, the railway service has never been credited with premiums on loans, etc. It is obvious therefore," the Commissioners add, "that, in order to ascertain the exact financial position of the railway at the present moment an elaborate investigation into the accounts would be necessary."

The Commissioners further make some remarks on the subject of unremunerative services which throw light on the caluses that may lead to Government-owned railways, largely influenced by political considerations, showing such poor results as they do. The report says on this point :-

In considering the working of the railway from the financial aspect, the Commission has been gravely impressed by the extent to which the expenditure is swollen by causes which are, more or less, outside the control of the railway management. Several lines are worked at a considerable loss, and without apparently any prospect of ever making a 
fair return on the capital invested in their construction. Between Cape Town and Simonstown several thousands per annum are expended by the Department in the employment of a staff whose numbers could be greatly reduced if the passenger traffic was under greater control and a system of single exits and entrances introduced at the stations. Another example of what the Commission has in view is the class of coal used on certain sections of the railwav. A loss estimated by the chief storekeeper at not less than $E_{3} \circ$,ooo per annum is borne by the Department owing to the use of Indwe coal, in place of Welsh, at East London, and the use of Colonial coal at other centres entails a loss which would largely enhance the above estimate. Again, certain classes of traffic are carried at rates which entail a considerable annual loss to the Department. In addition to these matters, and involving a greater loss than anything hitherto related, is the fact that the railway is confessedly overmanned in most of its branches. It is difficult to estimate with any accuracy the extent of the financial burden thus borne by the Department, for it is not merely confined to the loss entailed in the employment of men for whom no remunerative labour can be found (though this loss in itself is very considerable, and is estimated by the assistant general manager to amount to the sum of $\notin$ ioo,ooo per annum), but many other considerations are involved, since en excess of staff over the legitimate requirements of the Department must inevitably tend to a waste in materials, inefficiency in work, slackness in discipline, and general habits of extravagance.

Later on in their report the Commissioners refer to the construction of unprofitable lines, and say :-

The Commission considers that the information 
laid before Parliament in connection with schemes for new lines has in the past been often quite inadequate, and that Parliament has frequently been moved to sanction such schemes without a clear appreciation of the burden that will thus be thrown on the taxpayer.

On the subject of unnecessary clerical labour the Commissioners state :-

There seems to be, in the Railway Department, the same tendency to duplicate clerical work which the Commission condemned in its report on the Public Works Department. Between the chief officers stationed at headquarters something like 80,000 communications passed during the year 1904, and many of these might have been avoided by personal communications between the officers concerned. It is no doubt necessary and desirable to place on record for future reference matters of importance, but the number of useless letters that are written to each other by clerks in the same department calls for severe curtailment. The system of correspondence generally seems to be unwieldy; in one case which incidentally came before the Commission no less than fifty-eight communications (on five separate files) were written in connection with the raising of a wooden partition in a booking-office, a work which cost about $\mathscr{E}$ io.

Reference to the 1906 report of the general manager of the Cape Colony Government railways shows that, deducting merely total expenditure from total earnings for the year, the accounts certainly yield, on the whole, a good credit balance; but against this must be put interest due to the Treasury on capital expenditure, and the full amount of capital entitled to 
such interest in 1906 was $£_{30}, 642,000$. On deducting these interest charges, the operation of very few of the various sections leaves a balance, and the final outcome is a substantial deficit. In 1906, of the three main lines, only one-the Midland (400 miles) - made a profit on working, viz., $\mathcal{E}_{\mathrm{I} 12,134}$. The loss on the two others, the Western (80o miles) and the Eastern (288) was $£ 75,334$, leaving a net main-line profit of $\AA_{3} 6,800$. Of the twenty-two branch lines (, 414 miles) on which main-lines rates are charged, only two made profits, amounting to $\mathcal{E}_{4,405}$, the remaining twenty having losses, which came altogether to $£ 356,305$; while five branch lines ( 278 miles) on which special branchline rates are charged, made losses to the extent of $\ell_{27,424}$. The total net loss on the whole system in 1906 was thus $\mathcal{E}_{342}, 5^{24}$, as against one of $f_{104,581}$ in 1905 , and $t_{567}, 080$ in 1904 .

In his report for 1905 the general manager referred to the decrease in the deficit for that year, as compared with 1904, and stated that, while there was a reduction of $\mathbf{2} \cdot 34$ per cent. in the revenue for the year there was also one of $17^{\circ} 28$ per cent. in the expenditure; and he added :-

It is hardly necessary to say that retrenchment is an unpleasant undertaking; but in order to place the railways on a sound commercial footing, and inspire public confidence in further railway development, it became absolutely necessary to show that, 
by abandoning the policy of "waiting for better times," it was possible to make our railways contribute largely towards the payment of working expenses and interest on the large capital already invested.

\section{NATAL.}

I have already, in Chapter IV., made some references to the origin of the Natal Government railways. To the facts there mentioned I may add that the construction of these railways was attended by great engineering difficulties. From the sea level at Durban to Charlestown, on the Transvaal frontier, a distance of 307 miles, the line takes the form of a switchback. It rises to various successive heights, ranging from 2,000 to 5,520 feet, the aggregate ascent in the distance mentioned being equal to nearly $2 \frac{1}{2}$ miles of a vertical elevation. $U p$ to a few years ago the greatest weight the heaviest locomotives then employed in Natal could haul up the steepest inclines in the direction of the Transvaal was 137 tons gross, or 80 tons net paying traffic. There was also a tendency to assume that, because the cost of construction was to be defrayed out of the Colonial funds, everything should be perfect from the start, the policy of the railway pioneers in the United States being discarded in Natal even in the case of purely agricultural lines opening up virgin land to what were then extremely limited markets.

Conditions such as these have naturally 
affected not only the cost of constructon, which works out at an average of $£_{15}, 296$ per mile, but also the earning powers of the lines. In 1906 the net surplus of earnings over working expenses, betterments, interest, and sinking fund charges (all, in the case of this Colony, clearly shown and allowed for in the accounts), was $\$ 62,368$, as compared with $\mathcal{E}_{295,147}$ in 1905, and $\mathcal{E}_{17,515}$ in 1904. These net returns on a capital expenditure of $\mathcal{E}_{1}, 3,536$,ooo are not especially brilliant, and the fluctuations in the yield are a matter of some concern in a Colony which is the more disposed to look to the Government railways as a material source of revenue because of the difficulties experienced in inducing the Colonial Parliament to face what has been described as "the distasteful expedient of adequate taxation."

It is, however, an essential characteristic of the Natal as of the other Government railways in South Africa that their rates are arranged on a strictly preferential basis. There are, in fact, two distinct types of rates - special rates for Colonial products and class rates for imports, all being fixed on a mileage principle. The "South African produce rates," as they are called, are so low that they are admittedly non-productive. They do not even cover working expenses. Imports, on the other hand, pay rates which are generally twice, and sometimes three times higher; and it is the receipts from this source 
that are expected not only to enable the Government lines to pay their way, but, also, to contribute more or less to the Colonial exchequer. From the latter point of view, the railway rates on imports form part of the fiscal policy of each Colony, supplementing the direct charges already levied by the customs at the ports. So far does this system prevail that at the annual meeting of the Durban Chamber of Commerce in March, 1go8, the chairman, Mr. Henderson, in speaking of the Colonial finances said:- "The unsatisfactory feature of the position was the serious falling off in the import trade, which was, after all, the mainstay of their financial prosperity. It was from this trade that the Customs, harbours, and railways derived the bulk of their revenue and profit. It was this trade which" (among other things) " even enabled their country brethren to maintain their roads and bridges and branch lines of railway."

THE CENTRAL SOUTH AFRICAN RAILWAYS.

The system known as the Central South African Railways comprises the railways of the Transvaal and the Orange Free State, taken over and operated as Government lines, under the supreme control of the High Commissioner for South Africa, as one result of the Transvaal War. Their organisation and administration have been made the subject of very careful in- 
quiry by a Commission appointed by the High Commissioner, and the report of this Commission, dated Johannesburg, March 14, I908, gives some interesting facts as to the financial basis on which the lines are worked. It says, on this particular point :-

Besides finding a sufficient sum to meet the estimated depreciation of the railway assets, the administration, apart from other burdens, is also providing a sinking fund of one per cent. upon its capital liabilities, which represent the portion of the guaranteed loan of $£ 35$,000,000 that has been expended in the acquisition and construction of the railways. This provision is practically sufficient to pay off the whole of the capital liabilities in something between forty and fifty years. The Government's policy in redeeming its capital liabilities is not a question before the Commission, nor, indeed, is it an open question at all, in view of the terms of the Guaranteed Loan Ordinance of 1903; but, as a theoretical proposition, the Commission do not think it correct that the railways should contribute to such repayments. They know of no other railway which thus provides for the redemption of its whole capital; and, from a railway point of view, the wiser course would be to utilise the sum of $\mathcal{E}$ r88,694 now allotted annually for redemption purposes in reducing rates or in providing better facilities of transport. They recognise, however, that any recommendation upon the point must be of an academic nature; as a matter of fact the railway profits are at present used to relieve the revenues of the two Colonies of the whole charges on account of the interest and the sinking fund for the entire loan, and not only for that fraction of it which represents railway capital expenditure; nor is there, pending urification or federation of the South African 
Colonies, any practical prospect of relieving the railways from their extraordinary burden, still less of releasing them from the discharge of those liabilities which more properly belong to them. Nevertheless, if the day comes when it is no longer necessary to utilise the railway system as an instrument of taxation, the change should certainly be made. The railways should be enıancipated from the burden of the loan, and should be free to work out their development on commercial lines.

\section{CANADA.}

The financial results of the Intercolonial Rail way in Canada, which has been vested in and is controlled by the Dominion Government, are set out as follows in the Board of Trade Return, "Railways (Foreign Countries and Possessions)" :-

\begin{tabular}{|c|c|c|c|}
\hline $\begin{array}{ll}\text { Miles in operation } & \ldots \\
\text { Earnings } \quad \ldots & \ldots \\
\text { Working expenses } & \ldots\end{array}$ & $\begin{array}{cc} & 1904-5 . \\
\ldots & 1,414 \cdot 67 \\
\cdots & £ 1,394,391 \\
\cdots & £ 1,749,037\end{array}$ & $\begin{array}{l}\cdots \\
\cdots \\
\cdots\end{array}$ & $\begin{array}{c}1905-6 . \\
1,44492 \\
.1,1,571,232 \\
\delta 1,55^{\circ}, 505\end{array}$ \\
\hline Net loss $(-)$ or profit $(+)$ & $-£_{3} 6_{4}, 845$ & & $+£ 12,727$ \\
\hline
\end{tabular}

It will be seen that no allowance whatever is made here for interest on capital expenditure, the sum total of which amounted on June 30 , I906, to $\mathcal{E}$ r6,699,00o. Yet those of the colonists who do not trouble to look into the accounts are led to believe that in $1905-6$ the lines actually yielded a "profit" of $t$ i 2,700 .

In an article published in the Toronto Mail and Empire, in 1907, criticising the Inter- 
colonial Railway, it was asserted that, while revenue was duly credited to the railway, rails, locomotives and cars were paid for by the Dominion; and, also, that while not one cent had been devoted to the payment of interest upon the investment, the system had nevertheless made a loss in four years of $\mathscr{E} 800,000$. Whereas, again, the operation of each mile of the Canadian Pacific costs 68 per cent. of its earnings per mile, and the Grand Trunk a fraction less, the operation of each mile of the Intercolonial costs 125 per cent. of the earnings per mile. As regards political influences the same authority? said:"The entire railway is treated as patronage, and every politician on the right side is entitled to milk it."

Then the Montreal Gazette, in commenting in its issue of May 27, 1907, on certain reports concerning railway frauds in Russia, gave a list of various scandals of a similar nature in the Dominion, declaring that every job alleged against the Russian Autocracy had been paralleled in Canada. "First," it said-

There is the awful example of the Intercolonial Railway, probably as to construction the most costly single track system in North America, serving a good traffic-bearing country, with little or no competition during much of the year, and in connection with much of its length no competition at all; but so mishandled that one of its managers, giving up his job in disgust, said it was run like a comic opera.

Some years it does not earn enough to pay the 
cost of operation and maintenance, and every year it needs a grant of one, two, three or four million dollars out of the Treasury to keep it in condition to do at a loss the business that comes to it.

When land is to be bought for the road, somebody who knows what is intended obtains possession of it, and turns it over to the Government at 40,50 anci 100 per cent. advance. This is established by the records of Parliament and the Courts of the land.

INDIA.

As already explained (page 7), the Government of India prefer to leave their State-owned railways to be operated, as far as possible, by private companies, and in 1906-7, according to the report of the Committee on Indian Railway Finance and Administration, "the real net profit to the State, after meeting all charges properly attributable to revenue," was upwards of $E_{3}, 000,000$. So far, therefore, as actual financial results are concerned, it cannot be suggested that the Government railways of India are otherwise than a success.

But the Committee further say :-

The justification of the programme system is that the Government, although it allocates to railways in cach year the full amount that it expects to be able to provide consistently with financial prudence, is, nevertheless, unable in any year to provide funds for all the expenditure that would be profitable and advantageous. ...

Notwithstanding the large expenditure incurred since 1900 in increasing the facilities for traffic on 
open lines, the commercial and railway witnesses were practically unanimous in their opinion that in the years 1906 and 1907 the railways failed to deal satisfactorily with the traffic offering, and we are satisfied that this was the case. The chief complaint has been regarding the inadequacy of the supply of rolling stock; but the necessity for improving the lines by the addition of crossing stations, sidings, etc., in order to fit them for the employment of additional stock has also been represented as pressing. ...

There is wide scope for the construction of new lines. .... We are convinced that there will be fruitful fields for large reproductive expenditure on railways in the country for many years to come. . . But at the same time we recognise the financial difficulties that may be experienced when the Government commits itself to new and expensive schemes on a large scale.

So the Committee recommend that, in addition to the supply of increased funds for railway purposes by the Government, the working companies should not only have more of the State lines transferred to them, but should be encouraged to raise money for railway purposes by the issue of guaranteed debenture stock and share capital, with a share of surplus profits, as " a useful alternative to direct borrowing by the Government."

These various considerations detract somewhat from the satisfaction with which a " real net profit" of $£ 3,000,000$ a year might otherwise be regarded; and they show, also, that even a State may think it desirable to seek the assist- 
ance of private enterprise, not alone in operating its lines, but also in raising the capital required for general railway purposes.

\section{BELGIUM.}

The financial position of the State railways in Belgium has long been the subject of misapprehension because of the unsatisfactory, if not the wholly misleading, nature of the accounts, the main purpose of which seemed to be to conceal the real facts from the Belgian people, and lead them to assume that the State system was really in a most flourishing condition. Advocates of nationalisation in England have also readily adopted this view without any attempt at independent inquiry, and they have pointed to Belgium as affording an example of State wisdom, foresight, and enterprise which we should not hesitate to follow. The actual position of the lines, however, is now being more clearly understood. Ministers and politicians are rising in Belgium who insist on the old fictions and concealments being abandoned, and to-day it is the critics rather than the supporters of railway nationalisation theories who will turn to Belgium for arguments in support of their contentions.

From the report of the Belgian Minister of Railways for 1906, I find that if the balances shown during the period of operation are alone 
taken into account, there is a total of $\ell_{\mathrm{I}}, 768,720$ to the good. But, in making up these balances, no allowance has been made for interest to the Treasury for large sums advanced to the State railways in years of deficit, and the report considers that when the Treasury acts as banker to the State railway, interest on borrowed money should be allowed as in the case of a commercial company borrowing from a private banker. Taking these items into account, the report shows that the net result, instead of a balance of $\mathcal{E}, \mathrm{r}, 700,000$, has been a deficit of $£ 2,87$ I,000. The report concludes by suggesting that Belgium is evidently still far from realising the fiction that the State railways, by reason of their large yield, are "the milch cow of the Treasury."

The story is carried further by the report made by M. Hubert, representing the Central Section, on the Railway Budget for I9o8. He therein calls, as he says, "the very serious attention" of the Chamber to the actual results of operation as shown for 1907 and estiniated for 1908 . The Budget demanded for the State railways a vote L 879,000 in excess of that for the previous year (when it was $£ 6,500,000$ ), and M. Hubert says, "This is the greatest increase in expenses we have ever had to record." Already, he states, the proportion of total expenditure to net receipts has increased from $60^{\circ} 03$ in 1904 to $62^{\circ} 60$ in $1905,64.07$ in 1906, and, approximately, to 
$68.7 \mathrm{I}$ in 1907 . With the increase in expenditure proposed by the new Budget, there is, he finds, no indication of any stop in this ascending scale. While, in fact, the Budget contained supplementary estimates for $\mathcal{E} 920,000$, it provided for an estimated increase in the receipts amounting

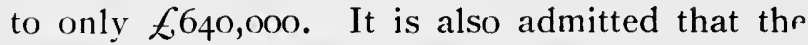
net revenue in the past from the railways taken over by the Government has been lower than the estimated profits. M. Hubert continues: "We have here a very grave situation, for if a change is not brought about we shall find ourselves in this position : either we shall have to cover by taxation a deficit more and more serious in a public service, or we shall have to raise the rates, a procedure which, in the actual situation, might be dangerous for industry, and, consequently, for the working classes."

\section{AUSTRIA.}

In Austria the State owns 5,000 miles of railway, and operates 2,700 miles of companies' lines. Of these it is now acquiring 1,860 miles, thus adding $\mathcal{E}, \mathrm{r}, 500$, 00o to the annual charge for interest. The State had already spent

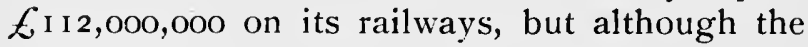
official accounts show " net profits on working" of $\mathcal{E}_{2,289,000}$ in 1904 , and $\mathcal{E} 2,976$,000 in 1905, the Board of Trade return says :-

No allowance is made in the above statement of 
expenditure for the repayment of capital. As, however, the rate of interest paid by the State on the loans raised for railway purposes is much higher than the rate of profit earned, the net profit has always to be supplemented by a large sum provided by the Rudget. The estimates for 1907 were :-

Amount payable by State for interest, )

$\left.\begin{array}{llcc}\text { amortisation, \&c., on } & \text { capital } & \text { for } \\ \text { State railways } & \ldots & \ldots & \ldots\end{array}\right\}$

Less profit on working... $\quad \ldots \quad \ldots \quad \ldots \quad 2,827,132$

$\begin{array}{ccccc}\begin{array}{c}\text { Estimated deficit to be provided by } \\ \text { the Budget }\end{array} & \ldots & \ldots & \ldots & \ldots 2,667,424\end{array}$

RIYSSIA.

Russia has been exceptionally unfortunate, from a financial point of view, in the operation of her State railways. In Europe she has 19 different lines, with a total length of 19,113 miles, and of these only nine showed, in 1902 (the last year for which full figures are available), a net profit after allowing for charges in respect to interest and sinking fund, the net loss for the year being $\mathcal{E}_{753}, 059$. On five separate lines in Asia the Government made losses amounting to $\notin 2,736,725$, the total loss in 1902 on the entire State system in Europe and Asia (excluding, however, Finland, the figures for which are not include(l in the Board of Trade return) being thus no less than $£_{3}, 489,784$.

\section{DENMARK.}

Denmark has definitely laid down the prin- 
ciple that her State lines must pay their way, and not be a burden on the taxpayers; but they are not to be operated in order to produce revenue for the Government " at the expense of users of the lines." Fares, rates, and charges are fixed on this basis, with the further stipulation, under a law passed in 1903 , that, from any balance left after meeting working expenses and standing charges, bonuses shall be paid to members of the staff, who thus have an incentive to operate the lines with a due regard to efficiency and economy. The accounts for 1906-7 show :-

\begin{tabular}{|c|c|c|}
\hline $\begin{array}{l}\text { Receipts } \ldots \\
\text { Expenditure }\end{array}$ & $\begin{array}{ll}\ldots & \ldots \\
\ldots & \ldots\end{array}$ & $\begin{array}{r}£ 2,182,514 \\
1,733,324\end{array}$ \\
\hline $\begin{array}{c}\text { Balance } \ldots \\
\text { Interest on capital } \\
(f 11,414,399) \quad \ldots\end{array}$ & $\left.\begin{array}{cc}\ldots & \ldots \\
\text { expenditure } \\
\ldots & \ldots\end{array}\right\}$ & $\begin{array}{l}£ 449,190 \\
£ 386,043\end{array}$ \\
\hline Bonuses to staff & $\ldots$ & $£ 63,147$ \\
\hline
\end{tabular}

SWITZERLAND.

Concerning the Swiss railways, the Board of Trade return says :--

The financial results of the purchase of the railways are described as satisfactory. Till the present time the revenue has been sufficient (I) to cover working expenses; (2) to pay interest on the purchase money; and (3) to pay for sinking fund on the debt incurred on the purchase.

This, presumably, is the official view. The unoficial criticism in the Tribune de Geneve- 
to which I have already referred (page 3o) in giving the reasons for the nationalisation of the lines-shows that since the State took over possession and operation the working day of the railway staff has been reduced from twelve hours to eleven; salaries and wages have gone up; more or longer holidays have been given; a considerable addition has been made to the number of officials-and there was an increase in the working expenses by 35 per cent. between 1903 and 1907 , while the receipts increased in the same period by only 28 per cent.

\section{ITALY'.}

Of the Italian State railways the Board of Trade Return, already mentioned, says that the net profits $\left(£_{2}, 030,824\right)$ paid into the Treasury for the year 1906-7 represent " rather less than I per cent. on the capital sum of $£ 226,254,000$ expended on the construction of the lines and purchase of rolling stock." (See, however, in this connection the reference to the Italian railways on page 29.)

\section{SERVIA.}

The receipts on the Servian State lines failed to meet the interest on the railway debt by $£ 92,300$ in $1903, £_{57}, 200$ in 1904 , and $£_{92,700}$ in 1905 . 


\section{HONDURAS.}

Honduras has a Government railway, for the building of which loans to the nominal amount of $\mathcal{E} 6,000,000$ were issued in London and Paris between 1867 and 1870 ; but even now not more than 57 miles have been completed. "It is impossible," says the Board of Trade Return, "to estimate the amount of money squandered on the construction of this railway."

\section{BRAZIL.}

In regard to the State railways in Brazil, the Return says :-

It is only during the last few years that the Central Railway [I,004 miles] has shown any profit at all, and that profit is so out of proportion to the cost of construction it may be inferred that no portion of the cost has been repaid.

\section{CHILE.}

The receipts in 1906 from the State railways in Chile failed to cover the expenditure by $\notin \mathrm{i} 77,258$. In his report on the trade of Chile for 1907 , the British Consul-General at Valparaiso says :--

The railways owned by the Government of Chile give no profit; in fact, they have latterly been worked at a loss. It may be strange that this should be so, seeing that the trunk system runs 
through splendid country that produces largely and promises to become much more fertile in future years. For there can be little doubt that, run on business lines, the railways could be made to pay, with properly trained officials, a revision of tariffs, and a greatly improved service. ...

The most important part of the broad gauge State railways is that between Valparaiso and Santiago, a distance of I 6 miles. All merchandise imported for Santiago is landed at Valparaiso.

Of these 116 miles of $5 \mathrm{ft}$. 6 in. gauge, only $8 \frac{1}{2}$ miles, from Valparaiso to El Salto, has a double line. The congestion of traffic at this point would be entirely relieved were this track doubled for the entire distance, and [this] would obviate the necessity of great expenditure on harbour works, such as are proposed. ...

The main line ... is suffering from inattention. Neither ballast nor sleepers have been renewed, and great damage has in consequence been done to the rails, and many accidents have resulted. The rolling stock is equally imperfect. Large numbers of German engines have failed to come up to expectations, and heavy steel wagons from Belgium have shown up in a surprising manner the weakness of the older wooden wagons.

The Consul-General's comments on the failure of the State lines to produce a profit are the more striking because the company-owned lines in Chile are fairly successful. Comparing the two systems, the Mining Journal declares that the position of the State lines affords "the most palpable evidence of incompetent management and careless administration, and the inevitable consequence of political influence." 


\section{JAPAN .}

The Railway Nationalisation Law carried in Japan in 1906 involved the purchase by the State of 17 lines of railway at a cost of about E50,000,000, and has been a material factor in the financial problems which have recently been engaging the very grave consideration of Japanese statesmen. The payment of the E.50,000,000 is found to be only part of the trouble. Those who inspired the scheme did not stop to consider that in addition to buying the existing lines, for the price mentioned, the State would require to spend a large sum of money alike on their betterment and on the provision of new lines, some of which are very much needed.

In regard to the new lines, at least, the Government find a difficulty in raising funds, and so we get this curious result : that within two years of the apparent triumph of nationalisation ideas in Japan, the Government have been proposing to revert to private enterprise, in order to secure the provision of additional transport facilities. It is even contemplated that the new lines shall not only be worked by electricity, but, in some instances, run parallel to the Government " steam " lines in order to " supplement" them -presumably, to render unnecessary a heavy expenditure on their widening or improvement:

Actual results are further indicated by the following extract from the report on the trade of 
Japan for the year 1907 , by Mr. E. F. Crowe, commercial attaché to his Majesty's Embassy, Tokio :-

The nationalisation of the railways of Japan was completed in 1907. The last of the seventeen principal private railways which were to be acquired by the State was taken over in October, so that it is now possible to obtain some idea of the working of the railways under the new system. Throughout the year there have been bitter complaints both in the native and foreign press about the railway service. One of the principal motives of the nationalisation of private railways was to remove the impediments and correct the confusion arising out of multiple ownership and divided administration. The critics, however, complain that the number of accidents has increased, that the delays in the transportation of goods are still excessive, and that on some lines unpunctuality is the rule and not the exception as it was in the days prior to nationalisation.

Mr. Crowe refers to a report issued by the Imperial Government Railway Bureau dealing with some of these complaints. It accounts for the shortcomings on such grounds as " not yet time to bring into force all the suggested improvements "; " rains and floods "; and " movement of troops during manœuvres "; and pleads, as extenuating circumstances, certain reductions in rates and fares; whereon $\mathrm{Mr}$. Crowe remarks :-

From the above figurcs it will be seen that the nationalisation has in some ways been successful, but the country as a whole seems to have expected more. 


\section{PRUSSIA.}

The country in the world which claims the best financial return on the operation of her State railways is Prussia, although the results even there are not really so great as the average nationalisation advocate represents. It has been said often enough in print or in public in this country that the Prussian State railways show a "profit" of about $\$ 30,000,000$ a year. Mr. L. G. Chiozza Money, M.P., for example, in an article published in May, 1908, sought to show how, under State administration, "profit arose unsought" on the railways in Prussia, and proceeded :- -

Thus, in 1904, while the receipts were $f_{7} 8,663,330$, the expenses were only $£ .47,553,497$, showing a net profit of $£ 31,109,833$, or $7^{\circ} 19$ per cent. on the capital employed. In 1905 the figures were even better. The receipts came to $t_{5}, 021,612$, while the expenses amounted to $\therefore 51,541,802$, showing a net profit of $f_{23}, 479,810$, or 7.54 per cent. on the capital employed.

A full translation which has been prepared of the "Accounts of the Railway Administration" gives Mr. Money's items thus :-

$\begin{array}{ccccccc}\text { Year. } & & \text { Receipts. } & & \text { Fxpenditure. } & & \text { Balance. } \\ 1904 & \ldots & £ 78,588,970 & \ldots & £ 48,487,696 & \ldots & £ 30,101,274 \\ 1905 & \ldots & £ 84,933,970 & \ldots & £ 52,530,490 & \ldots & £ 32,403,480\end{array}$

The variations in the two sets of figures are, however, a matter of detail. The essential point is that Mr. Money falls into the common error 
of regarding the difference between receipts and expenditure as " net profit," without making any allowance whatever for interest on capital debt and other standing charges.

The accounts themselves are given in the official report in such abundance, though with such lack of clearness, that they perplex the mind rather than present the financial situation of the State lines in a way that can be readily understood. The statement of accounts mentioned above comprises nineteen distinct columns of figures, going back year by year to 1882 ; but it will suffice to look at the items for 1905 .

Taking the balance of receipts over expenditure in that year as $\mathcal{E}_{32,403,480}$, there is deducted a sum. of $£ 5,332,598$ " for interest on the railway capital debt." This leaves (column 8) a net balance of $£ 27,070,882$. Then column Io says that "According to Sec. 4 of the Act of 27th March, I882, the original capital debt is to be written off by taking from this net balance (column 8) to the extent of $\frac{3}{4}$ per cent. on the capital debt," which stood at the end of 1905 at $£ 146,422,353$. The item given under this heading for 1905 is $£_{3}, 182,941$, and column il shows that "the net balance (column 8) after writing off this $\frac{3}{4}$ per cent. for sinking fund (column Io)" is $£ 23,887,941$. But the remaining columns proceed to allocate the "net balance" shown in column 8 with- 
out regard to the apparent subtraction therefrom of the sinking fund item of $63,182,000$ shown in column Io. The allocation of the said " net balance." is given in these later columns as follows :-

According to sect. 4 , sub-sect. 3 , No. I, of the Act of 27th March, I882, for the gradual extinction of railway debts taken over by the State previous to 1879 , and also contracted since then

For the reimbursement of $\ldots$ general $\begin{array}{llllll}\text { State expenditure } & \ldots & \ldots & \ldots & £ 23,205,049\end{array}$

For the formation or completion of a $£ 115,441$ reserve fund to be used for railway administrative purposes

Extraordinary Sinking Fund for State debts or for redemption of sanc-

tioned loans $\ldots \ldots \ldots$
For the formation or completion of $\ldots$ equalisation fund for the railway administration

$$
\begin{array}{cccc}
\cdots & \cdots & \cdots & \frac{£ 2,262,990}{£} \\
\cdots & \ldots & \cdots & £ 27,070,882
\end{array}
$$

Total

However all these figures are to be explained, one fact which may, I think, be regarded as certain is that the item of $\ell_{23}, 205,049$ is the amount which the Prussian Government secured from the railways in 1905 for general State purposes (" zur Deckung anderweiter etatsmässiger Staatsausgaben "). How this net gain for the Treasury was expended there is nothing in the accounts to show; but the item in question, though substantially less than the " net profit" spoken of by Mr. Money, is certainly, in itself, a substantial contribution to the State funds. 
Mr. Money is, however, again hopelessly wrong in suggesting that the "profit" from the Prussian State railways comes "unsought." I will not now stop to go into details; but my own inquiries into the operation of the Prussian State railways have led me to the conviction that they are designed to serve three main interests, stated in the following order : the raising of revenue as the first and most important object of all; political, commercial and fiscal considerations second; and the welfare of the individual trader as a very bad third.

One must further remember that if the railways in Germany were owned by companies instead of by the States, a considerably greater sum would be raised in the way of taxation. In Prussia the local taxes paid by the State railways amount to only $£ .750,000$ a year, whereas our own railways-having approximately the same length-contribute nearly $£ 5$, 00o, ooo a year. If the Prussian State railways administration paid local taxation on the same basis as the railway companies in the United Kingdom, the net profits shown would have to be reduced proportionately. As it is, the taxation which the Prussian State Railways avoid falls upon the ordinary taxpayer, who must set that item, among others, against his possibly lower rates for rail haulage.

Admitting, however, on the basis of the figures given, that, from the standpoint of financial 
results, the State railways of Prussia are a brilliant set-off to those of State railways-or the majority thereof-in other parts of the world, there still remains the consideration whether the Prussian Government have or have not been unduly anxious to keep up to a high figure the net railway returns coming into their treasury, with the result that they have refrained in the past from incurring all the capital expenditure necessary to enable the State railway system to meet adequately the growing needs of the trading community. In other words, have they, for the sake of immediate profits, neglected necessary developments in the interests of the future? If so, then the fact should not be ignored by those who would nationalise the railways of the United Kingdom in order that the State-that is to say, the Government of the day-may have the disposal of the "profits" thereof for old age pensions, or any other purpose that may appear to them desirable.

When the Prussian Government proposed to assume control of the railways of that kingdom, the representatives of commerce and industry wanted an assurance that the surplus from operation would be used for the lowering of the rates, for effective maintenance and development of the system, and for other such purposes, rather than for revenue purposes. The assurance was duly given, but in 1809 the Minister of Finance (Von Miguel) called 
attention to the amount which could be devoted from the railway balance to general State purposes, and said :-

We do not care about the increase in receipts; we only look at the net profit; and therefore we have every reason to deal carefully with the treasure we possess in our railways, and cannot afford to allow any decrease through a reduction in rates or an increase in expenditure.

Replying to those who criticised this policy, the same authority said:--

You talk about surplus. There is no surplus. It is all absorbed in permanent expenses. If these profits are not used for general purposes it will mean increasing the taxes by more than 100 per cent., and that is wanted by nobody. You had better leave us our treasure. This one will have cheaper fares; another will have better carriages and more room; a third will have new lines, even though they should be unremunerative. This one, again, wants better and finer stations; that one improvement of the road; another lower rates . . . In all this lies a danger to the State,- -at least, there would be if the Government were not strong enough to oppose, occasionally, the desires of those interested . . . . I assume that we Prussians will always have as strong an administration.

So the Government kept their treasure, practised economy, lowered rates mainly when it served purposes of State so to do, and saw the amount available from the railway revenue for general State purposes increase on the "leaps and bounds" principle year by year. Mean- 
while, what was the position in regard to the lines themselves?

Ten years ago the British Consul at Duisseldorf, Mr. T. R. Mulvany, in a report to the Foreign Office on the "Coal Industry in the Rhenish-Westphalian Provinces," wrote that the requirements of the Prussian State railways in respect to rolling stock had been much neglected; and he dealt, also, with the urgent need for the reconstruction of the permanent way, saying that associations of engineers had repeatedly drawn the attention of the State railway authorities to the fact that the rails in use were not able to stand the strain of the much heavier loads and the accelerated traffic of that day, the result being that, as he said, "were it not for the discipline and good management of traffic officials, the number of accidents would be far more alarming than they are." Mr. Mulvany further made the following remarks, which are especially significant in the light of subsequent events :-

Many years ago a man who was an authority on industrial and railway matters, foreseeing the development of which the country was capable, advocated the laying down, at least on through-going routes, of four lines of rails--two for goods and two for passengers - so that the fast and slow traffic might be kept separate and distinct. Of course, the adoption of this system, under the greatly increased value of land, buildings, and building sites, would now involve the expenditure of a much larger amount of capital than would have been at the time necessary; but unless canals are constructed to 
relieve the railways of the heavier portion of the goods traffic, it must doubtless sooner or later be done.

For a time the Prussian Government hoped that their policy of improving river navigation and building fresh canals would render unnecessary the very heavy expenditure on railway betterment that otherwise seemed to be inevitable, and that railway companies in the United Kingdom or the United States would probably have undertaken as a matter of course. But the inadequacy of the State lines remained, so that in a report on."Agriculture in the Rhenish Province," which Mr. Mulvany's successor at Duisseldorf, Dr. F. P. Koenig, presented to the Foreign Office in 1906 , one reads :-

It is a matter of fact that the German State rail" ays are no longer able to cope with the increasing amount of goods transport, and that something will have to be done to alleviate the pressure on the railroads, especially so on those of the Westphalian coal and iron districts, and on those of the Rhenish province, great industrial centres.

The grievances in question were due, not alone to an insufficiency of railway lines, but, also, to a chronic shortage of railway trucks. Turning once more to official authority, I read in the Report to the Foreign Office on the "Trade of the Consular District of Frankfort " for 1906, by Mr. Oppenheimer, British Consul-General there :-

For years there have been complaints concerning 
the insufficient number of trucks at the disposal of the commerce of the land, and more especially of the coal industry; and this scarcity at times becomes (especially in the autumn, when there is an increased demand for coals) a real calamity. This scarcity not only compels the mines to reduce the output, but also affects the workmen by forcing them at times to work in intermittent shifts only. Industry at large complains that in consequence of this scarcity it is put to great inconvenience because the delivery of coal has ceased to be punctual. The scarcity of coal and coke trucks was particularly acute last autumn [1906]. The highest figure for the Ruhr district was reached in the month of November, when, of the wagons needed, I $2 \cdot 2$ per cent. failed (against 6.9 per cent. in 1905); in the Upper Silesian district the record was reached in October, when 1 3.6 per cent. failed (against ro per cent. in I905). . . Quite recently the railway administrations have been approached by the leading mines and the coal syndicate for permission to allow the construction of private trucks of 20 tons each to facilitate the carriage trom mines to foundries generally.

The Chamber of Commerce of Mannheim, which is the most important river port in the South of Germany, complained that the scarcity of rolling stock was unprecedented. During the month of September there was an average scarcity amounting to 28.8 per cent. of covered wagons, and 36 per cent. of open wagons; during the last week of September the figures amounted even to 36.5 per cent. and 40 per cent. respectively.

Comparing recent State railway balances with the wagon shortages for the same years (as given in Mr. Oppenheimer's report), one gets the following significant table:- 


\begin{tabular}{|c|c|c|c|c|c|}
\hline & & & & $\begin{array}{l}\text { Balance of Prussian } \\
\text { State Railway } \\
\text { Surplus Available }\end{array}$ & $\begin{array}{c}\text { Shortage of } \\
\text { Wagons on } \\
\text { Prussian State }\end{array}$ \\
\hline I 896 & $\ldots$ & $\ldots$ & $\ldots$ & $\stackrel{\ell}{\stackrel{f}{6} 6,176}$ & $\begin{array}{r}\text { Number. } \\
36,109\end{array}$ \\
\hline 1897 & $\ldots$ & $\ldots$ & $\ldots$ & $10,013,235$ & 91,950 \\
\hline 1898 & $\ldots$ & $\ldots$ & $\ldots$ & $11,723,676$ & 43,39 I \\
\hline 1899 & $\ldots$ & ... & $\ldots$ & 13, I 40,980 & 67,553 \\
\hline 1900 & $\ldots$ & $\ldots$ & $\ldots$ & $14,500,980$ & 31,900 \\
\hline 1901 & $\ldots$ & $\ldots$ & $\ldots$ & I $6,01 \mathrm{I}, 667$ & 346 \\
\hline 1902 & $\ldots$ & $\ldots$ & $\ldots$ & $16,709,578$ & I, I 92 \\
\hline 1903 & $\ldots$ & $\ldots$ & $\ldots$ & $18,15 \mathrm{I}, 9 \mathrm{I} 2$ & 16,456 \\
\hline 1904 & $\ldots$ & $\ldots$ & $\ldots$ & $21,065,147$ & 38,350 \\
\hline
\end{tabular}

In 1905 the available balance went up to the figure already stated- $\mathfrak{E}, 23,205,049$, and in 1906 it rose still further, to $\mathcal{E}_{26} 6,043,922$. How the wagon shortage on the State railways stood in the same years in different coal districts is shown by the following figures, taken from $\mathrm{Mr}$. Oppenheimer's report :

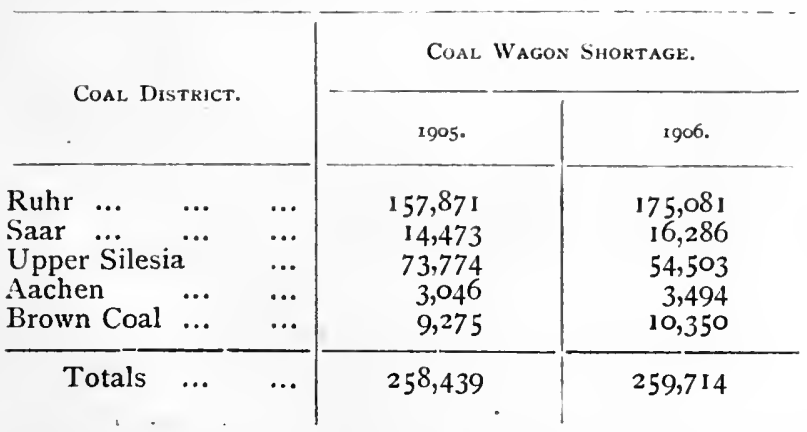

In the result we have the eventuality foreseen 
so long ago by Mr. Mulvany's “ authority on industrial matters ": that is to say, the Prussian Government find themselves compelled, at last, to expend on their State railways a sum far in excess of what would have been necessary had they provided for inevitable future developments at a time when land and building sites were of less value, instead of devoting their efforts mainly to securing a maximum of possible railway profits for the State treasury. In March, 19o8, the Prussian Parliament approved a railway programne which will involve an expenditure of no less than $\mathscr{E} 21,700,000$. This amount is to be spent on the building of new main, branch or narrow gauge lines; the provision of second, third, and fourth tracks for existing lines; the general betterment of various sections; the supply of additional rolling stock, and other purposes. The criticism that the extensions, at least, would have been less costly had provision been made for them in the past is undoubtedly just; and it is strengthened by this further consideration: that the sum thus required by the Prussian Government for railway purposes was included in a loan, floated in April, 1908, for which they then found it necessary to pay 4 per cent.

I would suggest that the very fact of a scheme of railway betterment, involving an outlay of

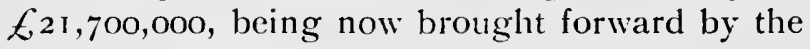
Prussian Government, fully substantiates the 
complaints as to undue economy in the past, and shows, too, what may happen when a Government learns to look upon railway operation as an important source of revenue, independently of Parliamentary votes. Railway nationalisation may get rid of the assumed disadvantage of private companies operating lines in the interests of dividends ; but if, for this, it should substitute a Government still more keen, and still more unyielding, in operating the railways as a revenueproducing machine, any possible benefit to the community would certainly not be without its drawbacks.

\section{WOLLD NATIONALISATION PAY?}

Looking at the whole matter from no higher standpoint than that of a purely business proposition, the general experience of other countries, apart from Prussia (allowing, however, for the attendant drawbacks experienced there), does not suggest that a financial gain to the community through the nationalisation of railways in the United Kingdom is to be regarded as a matter of course. Granting, freely, that in certain of the countries and colonies passed under review the State may have felt obliged to undertake either the provision or the control of the railways, and that in the case of our own colonies, especially, great benefits have resulted from the opening up of new country. to settlement, there is still no proof that State management, as 


\section{Railivays and Nationalisation.}

a whole, is more efficient, more economical, and more business-like than company management; neither, looking at the general results, is there any ground for concluding therefrom that State operation here would lead to such striking monetary benefit for the nation as might compensate for that disturbance with the finances of the country which nationalisation would inevitably involve. 


\section{CHAPTER VII.}

\section{STATE RAILWAYS AND POLITICS.}

ApART from those practical questions of State railway finance which I have already discussed, the question of railway nationalisation gives rise to serious considerations of policy in regard to the possible introduction of political influences which may operate to the disadvantage alike of the railways themselves, of the national or colonial Parliament, and of the public interests in general. Experience has shown that these influences may develop more especially in the following directions:-(I) Electoral pressure on railway ministers with a view to secure the construction of what are known as " political " lines, designed to serve the particular interests of individuals or of specially favoured localities, or, alternatively, to provide employment for electors; (2) the creation of a large body of State servants who might seek to induce their representatives to use their influence in Parliament to secure for them exceptionally favourable conditions of labour, at the expense, if necessary, of the general community; (3) the development 
of a tendency among politicians of all parties to promise these advantages as a means of securing the support of the employé-electors, even when the latter refrained from bringing pressure to bear on them in the directions stated; (4) the possibility of the time and attention of Parliament being unduly taken up by discussions on the grievances of traders or of railway servants which, though concerning matters of detail or discipline that should properly be left with the railway managers, could not be avoided by the Government in power for fear of the political consequences to themselves; and (5) the bringing of electoral pressure to bear on a Government to force them either to concede non-remunerative rates to certain industries or to refuse concessions to certain competing districts.

Political influences of these and other kinds have been brought to bear on the building or the operation of Government railways alike in British colonies and in foreign countries, and it is, to a certain extent, because of the possibilities of abuse of the system afforded by State ownership and State operation that these principles have been, and still are, regarded with so much favour in certain quarters.

\section{AUSTRALIA.}

Such abuse was certainly notorious enough in the early days of the Australian railways. I have referred, on page 70 , to certain lines in 
Victoria which had been either closed or dismantled because of the cost of working and the insignificance of the revenue. In effect these represent a type of railway constructed because the Railway Ministers were unable to resist the pressure either of certain political supporters to whom, personally, such lines would be useful, though they were not required by the community; or, possibly, of electors who wished to be empioyed to lay down the lines, and were not likely to be averse to further employment if asked to $\mathrm{p}^{\cdot}$.11 them up again a few years later. Owing, again, to like influences, the railway staffs became unnecessarily large, and the members thereof got liberal pay for doing " the Government stroke" during a generously-restricted number of hours.

The financial results to the railways were deplorable. The working expenses rose $5^{\circ}$ per cent., while the receipts remained about the same; repairs and the betterment of lines and rolling stock were neglected in order that money might be saved to meet the outlay on wages and unremunerative branches; while the undue interference of politicians rendered impossible the proper administration of the lines.

It was sought to overcome these various difficulties by the appointment of Railway Commissioners, who were (theoretically) to have almost unlimited powers of management and control. $V$ ictoria set the example in $188_{3}$, and South 
Australia, Queensland and New South Wales subsequently adopted a like policy. At first these Railway Commissioners were able to make their influence felt in checking the abuses which had crept in; but the Parliaments which voted the necessary supplies controlled the situation, and the pressure of the politicians, though exercised less openly than before, still made itself felt to such an extent that some of the Commissioners found their position hopeless, and gave up an apparently futile struggle against superior forces.

To show that the pressure of the politicians continued, notwithstanding the appointment of the Railway Commissioners, I may allude to what happened in New South Wales in 1902, or I 4 years after Sir Henry Parkes had, by adopting the policy in question, sought to check the abuses due to the subjection of railway management to political influences. The Labour party, who then held the balance of power in the Colonial Parliament, secured the passing of an Act which forced the Railway Commissioners to make concessions to the "running" staff at an estimated cost of $\mathcal{E} 60$, o0o a year, the most important of the new regulations being that the men were to work eight hours a day instead of nine. On the other hand, they considered that $\mathcal{E} 6$, ooo a year was too much to divide between the three Railway Commissioners, although these gentlemen were discharging duties which 
here fall more or less upon the boards of directors and the chief executive officers of the railways. They desired to economise in this respect by dispensing with the services of the Commissioners and having, instead, a general manager at the lowest possible salary, more money being thus made available for the wages of the "running staff," in whose welfare the Labour party were mainly concerned. This, however, will be found to be the invariable attitude when "Labour" gets a controlling or even an influential voice in the management of publicly-owned enterprises. From the point of view of the average labour representative the responsible officers are always paid too much and the rank and file too little.

As further illustrating the conditions which may exist in regard to colonial railway operation under a régime of Government control, I would refer tc an inquiry held in Victoria in Igor by a Select Committee on the Management of the Railway Department (Appointments and Promotions). The department, it seems, had been invested with power to make permanent appointments to the Railway Service, but, " through lack of perception or neglect" (as the Select Committee reported) in making application for a sufficient number of permanent employés, so-called " temporary" employés had been put on by the higher officials in the various branches to such an extent that these "supernumeraries" represented, in 
126 Railways and Nationalisation.

I9OI, no less than 34 per cent. of the staff3,037 out of a total of 11,956 . The Committee found that " in making these appointments official patronage was freely exercised, the officials responsible being, apparently, influenced in their choice by personal or other considerations." There was an official register of applicants, but the officer in charge of it admitted to the Committee that " his list was practically a farce, and that supernumeraries were appointed irrespective of it." Under the Act dealing with such appointments no person was to be employed as a supernumerary for a longer period than six months in any one year; but the Committee say :-

This provision is frequently set at defiance. Many supernumeraries who come within the category of those prohibited by the Act from being employed for more than six months have been kept continually employed for years, their retention apparently being, in most instances, the outcome of personal favouritism. Some of these, among them the sons and relatives of officials, applied and were appointed as supernumerary repairers, and were entered in the staff register as such, but were immediately given elerical work to perform. After years of constant employment as supernumeraries, when applications for permanent appointments were invited, these men applied and were permanently appointed as repairers, but have ever since been engaged at clerical duties. Many of the supernumeraries have, by reason of their continuous employment for ten or twelve years, virtually become permanent employés. 
The Committee further say in their report :-

Regarding the medical examination to test the colour-sense and visual efficiency of candidates and employés, your Committee is surprised to find that the experts and the higher officials are not more in accord in their determination of what degree of efficiency is essential to the safety of the general public. In numerous instances the certificates of the medical gentlemen have been over-ridden by the opinions of officers in the various branches of the Department. Employés performing duties of great responsibility have been allowed what is called a practical vision test by the Department, and kept in their positions despite the fact that they were previously unconditionally rejected by the medical men. Cases are on record where engine-drivers rejected by doctors for defective vision have been employed until cven the so-called practical test was beyond their ability to pass.

One can scarcely conceive the possibility of conditions such as these coming into existence in the case of any company-owned railway in the United Kingdom. It may be pleaded that they have since been-reformed in Victoria and in the other colonies where they may have developed. But the fact that they should have been found at all does not confirm the suggestion as to the superiority of Government over company management.

Even to-day there are politicians in Australia who seek to gain the favour of electors by advocating extensions of the railways regardless of any considerations, either of railway policy or of that colonial credit for which the railways 
constitute the chief asset. In the recent elections in Queensland, as told by the Australian correspondent of the Economist, in the issue of that journal for April I \&, 1908, one political leader advocated the construction of a number of railway branches, the cost of which would be very great, while another leader, not to be outbidden by his rival, promised to support many more.

\section{NEW ZEALAND.}

Reverting to Professor Le Rossignol's comments on the position of the Government railways in New Zealand, it is significant to find that he considers their "financial failure" (as he calls it) to be largely due to political influences. This American authority says :-

Politics have had altogether too much to do with the construction of roads, the appointment and promotion of officials, the frequency of service, the fixing of rates, and the departmental administration in general. Railways have frequently been built for the sake of securing votes rather than traffic, and business has been so often subordinated to polities that it is no wonder that the net returns are political rather than financial in their character.

He thinks, however, that even now, under efficient management, the system could be made to pay. "It is," he suggests, " altogether probable that a private company could so operate the roads as to pay interest on the capital cost, taxes on its property, and moderate but increasing dividends 
on its stock, and, at the same time, reduce rather than increase the charges for passengers and freight. From a mere financial point of view," he adds, "it would pay the Government to sell the railways to a private corporation, which, like the railway companies of the United States, would do much to develop the varied resources of the country."

\section{CAPE COLONY.}

Dealing with the subject of "The Nationalisation of Railways" from the point of view of his experiences on the Cape Government railways, on which he has been engaged for some years, Mr. William Ben Edwards said, in the course of an article published in The Nineteenth Century for March, I908 :-

As the combined railways of the country would form one of the greatest spending and earning Government departments in the world, it is obvious that the head of the department would have to be a Cabinet Minister, with a seat in the House of Commons, and answerable to the House for all the details of the business over which he presided. He would at all times be liable to be questioned on any and every trivial matter connected with the railways, and, if he failed to satisfy his inquirer, the latter could move the adjournment of the House to discuss the matter, provided he received the support of forty other members. . . . The author can remember a case at the Cape when the Minister for Crown Lands and Public Works was questioned about the overcrowding of a compartment in which his interrogator had travelled to Cape Town. In another case 
a member asked the Minister why he had not been allowed to pass a barrier at the terminus to see someone off when he had no ticket.

The ordinary Parliamentary procedure at the Cape may be briefly described as follows: Suppose notice of a question was given to-night, the Minister at once communicated with the General Manager of Railways, who, the first thing in the morning, would transmit the wording of the question to the head of the sub-department concerned, say to the engineer-in-chief, who would at once telegraph for particulars from his local subordinate on the spot, commencing his inquiry "Parliamentary." 'The local officer would reply with the necessary information as quickly as possible, which would be sent on to the Minister, who would, perhaps, to-morrow night rise in his place in the House and answer his inquirer in the words of the message sent by the lecal official away up the country. It should be understood that at the commencement of each Session all chief district officers received strict instructions that ary message commencing "Parliamentary" "was to have precedence of all ordinary business except the safety of the trains and public.

It is also evident that the whole of the legislative machinery would be liable to be upset by a defeat of the Government on a railway question. Would the country be prepared to pass through a Cabinet crisis, or even a general election, because a branch line to some almost unknown spot was rejected?and this would only be the logical result if the Government failed to carry their measure. The Cape Government in 1890 went out of power on being refused money for branch lines.

To this I may add that in 1907 the Governor of Cape Colony appointed a Commission to enquire into the question of railway management and 
the construction of new railways, and this Commission, in its report (which recommended the establishment of a Railway Board to advise the Minister of Railways in all important matters of policy) said :-

It is impressed with the necessity of removing, a: far as possible, the management of the railways fom the influence of party politics without, at the same time, lessening the legitimate right of control which must be exercised by Parliament as the representative of the taxpayers.

\section{NATAL.}

The colony of Natal has its " political " lines, these having been built to serve the interests of certain agricultural communities in localities where there could be little or no hope of working expenses being covered under ordinary conditions. On the other hand, the existence of these very lines was of invaluable strategic advantage in the eventful period of the Boer War, from 1899 to 1902 ; they were of a still more marked benefit during the native rebellion of I906; and they also conferred an incalculable advantage, not only on Natal, but on South Africa in general, in 1907, by allowing of the rapid manipulation and quick distribution of troops from the branch line termini at the time of the threatened rising in Zululand. In these respects, therefore, the building of the lines in question has, in this in- 
132 Railivays and Nationalisation.

stance, been abundantly justified by unforeseen results.

Another fact, not to be ignored, is that South African legislators have a personal reason for preferring Government to private ownership of railways, inasmuch as, on being elected, each of them receives a free pass entitling him to travel over the Government lines, not only in his own colony, but in all the other British colonies in South Africa as well. Such pass is available during the full period of his membership, whether the "House" to which he belongs is in session or not. Should the member be a business or professional man, requiring to go pretty frequently between, say, Durban and Pretoriaa journey of 5 I I miles, for which an ordinary first-class return ticket costs $£ 8$ s. 7 d., and a second-class return $\&_{6} 3 \mathrm{~s}$. 4 d.- the privilege of being able to travel as a Parliamentary " deadhead" whenever he pleases must be a valuable perquisite; though the general manager of the Natal railways, in his report for 1906 , bewails the fact that the issue of so many free annual passes involves a "heavy loss of revenue" to the railway department.

CENTRAL, SOITH AFRICAN RAILIVAYS.

The Commission appointed in 1907 to inquire into the organisation and administration of the Central South African Railways (Transvaal and Orange Free State) spoke very emphatically of 
the dangers that might result from the exercise of undue political influence in the operation of the lines. They said on this subject :-

The Commission have been impressed by the earnest warning which has been addressed to them by several witnesses and informants against the danger of allowing political influences to intrude upon questions of railway construction and management. Such influences may affect both matters of domestic and matters of foreign policy. In the former case they may have such consequences as the censtruction of unremunerative lines, or granting of unremunerative rates, or local purchase of supplies without sufficient justification; or even the employment of unnecessary hands, or payment of unnecessarily high salaries or wages, or appointment of unsuitable officers. Other colonies in South Africa and elsewhere have experienced some or all of these evils. . . From such consequences the Central South African Railways have fortunately been free, and it is most important that their freedom should continue. In this view the arrangement made by Lord Milner, which placed their administration in the control of a body not responsible at first hand to the popular electorate, was happily devised. A joint administration, such as the Railway Committee has been, has the great advantage that it minimises, so far as may be, the mischief of political interference. Whatever changes are made in future, the Commission would not welcome any step which would render such interference easier.

There is the question, again, as to how far a Government-owned railway should be concerned in the general policy of the State or Colony in 
134 Ralliways and Nationalisation.

which it operates. On this the Commission said

The remaining aspect of the question, which concerns what may be called the foreign policy of the railways, is of even greater importance. In this respect the Central South African railways share a disability common to all the railways in South Africa, which, from the days of their construction, have been the pivot of South African inter-colonial politics, and are likely to remain so until some definite steps towards their amalgamation are taken. So long as this state of things lasts, it is obvious that the larger questions of railway policy must be determined by the Colonial Governments and Parliaments which have so vital an interest in the issues of which the railways are one battlefield. But the unhappy results which have ensued, particularly in the matter of the through rates from the ports, are notorious throughout South Africa. The railways are neither run as a commercial concern nor allowed to play their legitimate part in promoting the derelopment of the country. . . . As matters now stand, not only does the financial equilibrium of the respective colonies depend largely on their railway rcrenue, and consequently on their power of attracting and holding as large a sharc as possible of the total South African traffic, but there is a tendency to make an illegitimate use of the railways for the purpose of creating trade and manufactures in violation of the spirit of the existing Customs Union.

There can be no doubt that in an undertaking. of such magnitude as a large railway it is unsound to attempt to combine diplomatic and executive functions. - . . They do not feel sure that any satisfactory solution can be found, short of the amal- 
gamation of all South African railways, and their extraction from the slough of politics once for all.

\section{BRAZIL.}

A well-recognised form of political corruption in Brazil, in the days when railways were more extensively owned by the State, was the employment of a considerable number of extra workers on the Government lines prior to or pending a General Election.

\section{BELGIUM.}

The extent to which political influences are brought to bear on the operation of the Belgian State railways is fully shown by the translation of M. Marcel Peschaud's articles in the Revue Politique et Parlementaire which I have given in my book on "State Railways." Here it may suffice to mention that $M$. Peschaud quoted the following remarks made by $M$. Hubert so far back as 1889 :-

Every instant some member rises, demanding improvements in the service, the creation of new stations, the arranging of more stoppages, or the cencession of tariffs of greater advantage to industries in which he is interested. Then, for improving the position of the officers, officials, and labourers, notwithstanding the sums already expended under this head, what complaints and demands are not put forward. Here we have an evil inherent to exploitation by the States : money that belongs to everybody belongs to nobody. 
In 1904, M. Peschaud further stated, the Belgian Minister of Railways said that the sum total of the expenditure involved in carrying out the amendments proposed by a single deputy would be $£ 90,400$; and in 1905 he further calculated that the amount concerned in the amendments proposed for improving the position of the personnel represented an increase in the salaries and wages paid of 40 per cent.

Added to this, the grievances of the railway servants are made the subject of almost interminable debates, while Parliamentary candidates openly bid for the votes of the railway electors by promising them better conditions and assuring them they have nothing to hope for in this respect "from the other side."

\section{GERMANY .}

There is much less suggestion of the exercise of political pressure by railway men or their Parliamentary friends in Prussia, partly because the Government are in a much stronger position than is the case in Belgium or in the British . colonies, and partly because the working classes, as a whole, have but a very slight representation in the Prussian Diet.

Yet Social Democrats in the Imperial Diet do not hesitate to bring forward the grievances of their comrades on the State railways, alleging that the hours of service are too long and that 
accidents are the result. When, however, these representations were once more advanced early in 1908, the President of the Railway Bureau, Dr. Schulz, showed that the larger number of accidents occurred early in the day, when the men were fresh, and not later on when they might be supposed to be fatigued.

In Baden a Social Democrat was discharged from the service of the State railways on his being elected a member of the city council, and protests were raised in the Parliament there by the Social Democrats; though the dismisal was defended by the Prime Minister on the ground that the Social Democratic party regards strikes as one of the most important means of obtaining its ends, and the State railway authorities could not run any risk of interruption of so important a public service.

On the other hand, there has been a considerable tendency in Germany to bring political pressure to bear on the Government to prevent the concession to one set of traders, or to one particular district, of lower rates or advantages that might possibly operate to the disadvantage of other traders or other districts. Whereas a railway company need consider only the people served by its own lines, a Minister controlling a network of State railways extending over the whole country must balance as far as he can the interests of one locality against those of another; and, where there is conflict between these 


\section{Railways and Nationalisation.}

different interests, he may be forced to withhold or to withdraw otherwise desirable concessions, for fear of possibly undesirable political consequences. As I have already dealt with this branch of the subject in the chapter on "The Railways of Germany" in my book on "Railways and their Rates," I will here do no more than refer to the example, given on page $26 \mathrm{I}$ of that book, showing how the Governments of Saxony, Baden and Würtemberg, by threatening Prussia with the opposition of their representatives in the Reichstag and the Bundesrath to the Imperial Bill authorising a commercial treaty with Russia, compelled the Prussian Government to cancel certain reductions of grain rates which placed the traders in the three States in question at a disadvantage.

\section{FRANCE.}

Nuch of the trouble experienced with the railways in France has been clue to the fact that deputies, yielding to the pressure of their constituents, themselves brought pressure to bear on successive Ministries to construct or effect the construction of small lines which may have been of local convenience, but were doomed to be financial failures owing to the insufficiency of the traffic. It was mainly through inducing the great companies either to build or to take over lines of this description that the French 
Government had to enter into, with them, those financial complications that came within the range of " guarantee of interest."

As regards State servants in France a law passed in 1884 forbade State employés to form trades unions; and even so thorough-going a Radical as M. Clemenceau has persisted, in spite of all protests, in his refusal to allow them to become members of the Confederation du Travail, and has spoken most vigorously in defence of the position he has thus taken up. The main difficulty felt by successive Ministers in France, in the way of modifying the law, is the drawing of the line between the right to form a trade union and the right to strike.

\section{IIOLI.AND.}

Fear of possible political disadvantages was one of the reasons why, in May, I9o8, the Second Chamber of the States-General in Holland rejected (after five days' debate) a resolution in favour of a scheme for the operation of the State railways there by the Government themselves, instead of by a private company as at present. Dealing with this point in an article on the subject which, following on a visit to Holland, I contributed to the Railway News of June 6, 1908, I wrote :-

If, it was argued, the Government of a small country like Holland, owning and operating all its cwn railways, had to negotiate on questions of 
through traffic with the Government of a powerful neighbour, also owning its own railways, there would be much more risk of delicate diplomatic situations arising than if such negotiations were carried on by private companies. One member, Mr. Plate (late president of the Rotterdam Chamber of Commerce), mentioned, without going into details, that Belgium had been obliged to make certain concessions to Germany in railway matters from what were obviously political considerations.

It was held, also, that domestic as well as international politics might be involved. The SocialDemocrats had shown a special interest in the possibility of getting better wages and conditions for the railway workers; but the more cautious members did not like the prospect of 30,000 railwaymen being directly employed by the State, especially as the Dutch railways could not give higher wages than at present, and still pay their way. Fears were, again, very frankly expressed that there would be a repetition in Holland of the conditions experienced in Belgium, where, it was pointed out, Deputies bid for the votes of railway electors by promising them increased pay or other advantages, and compromise the railway situation by trying to force the Government to carry out the promises thus made.

In other directions there have already been tendencies to introduce political or social considerations into railway working in Holland. A certain member of the Second Chamber actually induced the responsible Minister to compel the Holland Railway Company to stop the Paris-Amsterdam express at Haarlem, because he would then be enabled to reach his home by dinner time after the sittings of the Chamber; and the express has been locally known by his name ever since. When, therefore, in the course of the debate, a Social-Democrat member, Mr. Schaper, said, "Why do you fear political interference with the railways? We have already got 
the Hugenholtz express. What could be worse than that?" there was a roar of laughter in the House. In another instance, the Minister himself trièd to induce the Holland Company to put on a new and confessedly non-remunerative train so that the children in a certain district could get to school in time; but, as he would not either guarantee the company against loss, or allow them to withdraw arother train instead, they declined, on this occasion, to comply with his wishes.

\section{VIEWS OF A DUTCH AUTHORITY.}

In a conversation I had with the late president of the Rotterdam Chamber of Commerce during my visit to Holland, Mr. Plate made some observations so thoroughly to the point that I venture to reproduce them. He said :-

There is no system which in itself is absolutely perfect, but there is more to be said against the operation of railways by the State than in its favour. Much depends on national wants and conditions, and, also, on the mutual relations of Government and Parliament. In Prussia you have a strong Government and a weak Parliament. In Holland we have general elections every four years, so that there might be a continuous change in railway. policy, the more so as even the details of railway operation would-in our country-be made subjects of Parliamentary debate. In England the general elections are less frequent, and the railway policy might be more permanent; but you still have a Parliament which is much stronger than the one in Prussia. In the one case, th refore, the Government can control the railways as they please, Parliament having little or nothing to say; whereas both in Holland and in England Parliament would have everything to say, and would readily 
impose its will on the Government. I remember that an ex-Prussian Minister, who took part in the negotiations for the purchase of the railways there by the State, once said to me: "That Prussia should have taken over her railways was quite right; but the adoption of a like policy in your country-that's another matter. State railways are only possible where you have a strong Government, or where larliament does not want to interfere, and the operation can be carried on without Parliament being consulted."

In Holland there would be two strong arguments against State operation: (I) From the moment the Government themselves undertook to work the railways attempts would certainly be made to bring influence to bear on Parliament in order to secure increases of wages for the employés. It would not be merely a question of the Labour Party doing this out of sympathy with their friends outside. Members of all parties would think it desirable to secure the electoral support of a large body of Government workers. (2) Under a system of State operation, people living in outlying districts-in the North of Holland, for instance-where the passenger traffic is small, would demand of the Government that they should have a larger number of trains, and be placed more on a footing of equality with the residents in central districts, where the traffic is large. In each of these two instances you would get Parliamentary interference and an increase in working expenses.

Then it is easier for a private company than it is for a Government to put the right man in the right place in the operation of a railway system. If a private company thinks fit to pay a good salary in order to secure the services of an excèptionally capable man, it can do so. On a State railway it might, in these circumstances, be necessary to get a Parliamentary vote, and you would find there were 
members who, though keenly alive to the need of good pay for the ordinary workers, would resent the giving of a substantial amount to the occupant even of a highly responsible post.

A railway company, again, in making an appointment, is in a position to consider efficiency only; while a Railway Minister will be expected, in making his appointments, to satisfy his political supporters and not to offend his political opponents. He may thus be influenced by personal considerations, and by a desire to be regarded as impartial, rather than by the question of efficiency alone.

One must remember, also, that both private companies and Governments make mistakes in their choice of men. But whereas a private company can easily get rid of, or transfer to another post, a person found to be not the right man for the place, it is much more difficult for a Government to make a change which may involve questions and unpleasant debates in Parliament. So the tendency would be for an inefficient, though not absolutely incompetent, State official to remain in his post, when once appointed, and the service might suffer in consequence.

Besides the certainty of wages questions being raised in Parliament, there would be the prospect of railway men's grievances being frequently brought forward for discussion. In Holland petitions from public servants with complaints to make are already freely presented and debated on at considerable length. What would be the position when we had 30,000 more State servants, as railway workers? Is it not likely, also, that heads of departments would hesitate to discharge undesirable men if they had to run the risk of all the unpleasantness which Parliamentary intervention might involve? Do you not think the whole tendency of such conditions would be to weaken the discipline which ought especially to be maintained in the operation of so important an undertaking as a railway? 


\section{CHAPTER VIII.}

\section{STATE RAILWAYS AND LABOUR.}

"WE most emphatically express the opinion," declared a resolution passed, with only two dissentients, at the Middlesbrough Congress of the Amalgamated Society of Railway Servants in October, 1907, "that State ownership is the only practical solution that will confer permanent benefit upon railway workers and all other sections of the community."

Labour's point of view on the nationalisation controversy is essentially one of self-interest. The words, " and all other sections of the community," were probably added to the foregoing resolution for the sake of appearances; but the very slight regard that was shown for the interests of these other sections in the threats of a railway strike in the United Kingdom in the autumn of 1907 , as well as in railway troubles elsewhere, strengthens the impression that the one great attraction which State ownership has for the railway man who believes in it is the possibility of his getting from the State shorter hours and higher pay. Provided that he could secure these results, the other sections of the 
community would have to take their chance, and even, it may be, suffer in order that he may gain.

Sir John Gorst has assured railway men that, with State ownërship, shorter hours and higher pay would accrue to them; and it would certainly be contrary to all precedent if, on the advent of nationalisation, the railway men did not bring to bear on the Government all the pressure they could, political or industrial, in order to secure the fulfilment of their aspirations. But, unless the cost is to fall on the community, any really material betterment of the railway men's position under State ownership and operation would be dependent mainly on the possibility of effecting the much-talked-of economies. These, according to the nationalisers, are to be secured mainly through abolishing the railway directors, getting rid of duplicate railway services, etc. But any saving on the fees of the former would probably go to paying the staff of State officials taking over the duties of supervision, and would not, probably, be available for the ordinary rank and file; and any substantial reduction in the number of trains run would mean that fewer men would be wanted, so that many of the present staff, instead of having their conditions improved, would have to join the unemployed.

\section{DECREASED STAFFS.}

During the debate on the resolution from which I have already quoted the unpleasant 
prospect of a decrease, under nationalisation, in the number of railway men employed was pointed out by Mr. Richard Bell, M.P., general secretary of the Amalgamated Society of Railway Servants. Amid cries of "Question!" he said :-

He had listened to the speeches, and it was with pleasure he recognised how ready and anxious and willing every one of the speakers was to make sacrifices in the interest of the public benefit. . . . But what he wished to say was just by way of recording the fact that, when the time for the nationalisation of railways came, many thousands of railwaymen would have to suffer. . . . There was no question about it. There was a quantity of surplus labour now which would be increased if all competition were done away with and the railways were put under one company or one body. They must not forget the fact.

\section{CLERICAL STAFFS.}

One of the stock arguments of the nationalisers is that, with a single State system the services of "about 3,000 clerks" in the Clearing House could be dispensed with, and economies secured in this direction. "All this labour," says one writer on the subject, " is pure waste, necessitated by competition." Incidentally he does not stop to consider that this competition has been deliberately fostered by successive Governments, supported by public opinion, since the earliest period of railway history. Be that as it may, it seems to be thought that the salaries of about 
3, ooo clerks would be useful for increasing the wages of drivers, firemen, platelayers and others. Perhaps so. But it would also mean the throwing of another 3 , ooo persons on the unemployed list.

While, however, manual workers are ready enough to demand that every possible consideration must be shown for their own interests, they are apt to ignore any right to equal consideration on the part of clerks, accountants, bookkeepers and others who may also have a pardonable desire to live, and move, and have their being.

\section{RF-ABSORPTION IN OTHER INDUSTRIES.}

When giving an address on the nationalisation of British railways at the Wardle Free Library in January, 1908, the Rev. H. V. Mills, of Kendal, said, "If the railways were nationalised, 40,000 men would be rendered temporarily idle; but such an impetus would be given to trade in other directions that employment would soon be found for them."

Mr.'Mills' assurance would probably not be regarded by the 40,000 men as particularly reassuring. It is the same sort of argument that socalled" "temperance" reformers use when advocating the wiping out of the liquor industry. Unfortunately, industrial revolutions are not recovered from quite so easily.. There is the personal difficulty in the way of men brought up 
to one particular class of work adapting themselves readily to another; and there is the commercial difficulty in the absorption of unemployed persons by industries already fully supplied with men, and not likely, in the case in point, to undergo further expansion simply because the State had acquired the railways under conditions which must, in themselves, have a considerable effect on the money market. In the end railway men would see brought about in the railway world an industrial upset from which few of them could hope to gain, and many would be certain to lose.

\section{NUMBER OF RAILWAY WORKEIRS.}

A return issued by the Board of Trade shows that the total number of railway servants, in all grades, at the end of 1907 , was $621,34 \mathrm{I}$, classified as follows :-

Enginedrivers \& mo-

tor men ... ... 28, I 4 I

Firemen $\quad \ldots \quad \ldots .25,714$

Goods guards and

$\begin{array}{lll}\text { brakesmen } & \ldots & 16,786\end{array}$

Passenger guards ... 8,474

$\begin{array}{lll}\text { Signalmen ... } & \ldots & \mathbf{2 8 , 6 5 8}\end{array}$

Pointsmen $\ldots . \quad \ldots \quad 745$

Shunters $\ldots . \quad \ldots \quad 13,158$

Permanent way men 67,184

Permanent way inspectors ... $\quad \ldots \quad$ I, I 45

Other inspectors $\quad \ldots \quad 8,084$

Ticket collectors and examiners
Stationmasters $\quad \ldots \quad 8,688$

*Porters . ... ... 56,402

Policemen ... $\quad \ldots \quad 2,127$

*Engine cleaners ... $21,45^{8}$

* Carmen and vanguards, etc. $\quad \ldots \quad 24,256$

* Carriage cleaners and examiners ... $\quad 10,720$ Men and women clerks $\ldots \ldots \quad \ldots \quad 58,503$

Boy and girl clerks (under 18) $\quad \ldots \quad 10,672$ *Labourers ... ... 59,812

* Mechanics \&artisans 93,797 * Miscellaneous ... 33,083

* Including persons under eighteen years of age. 
THE LABOUR VOTE AND INTEREST.

Even if all the railway men now employed were kept on, and whether they secured any increase in wages and decrease in hours or not, some very material changes might have to be brought about in their general position. As employés of the State they would have to be regarded from a different standpoint from that of employés of commercial companies.

I have shown in an earlier chapter the sort of political pressure which railwaymen in other countries have, under State ownership, brought to bear on their Governments in order to promote their own advantage. It is too much to assume that there is no probability of similar difficulties arising here. What the position is already was shown in some remarks made by Lord Joicey on the occasion of the annual meeting of the Newcastle Chamber of Commerce in May, 1908, when he is reported to have said, in regard to railway nationalisation :-

He should always oppose such proposals, for Government control would be neither as economical nor as effective as private enterprise. A great danger would also lie in political power given by such nationalisation, a matter in which they had an object-lesson in dockyard members, whose aim seemed to be the betterment of their constituents at the expense of the nation. 
THE EXAMPLE OF THE POST OFFICE SERVANTS.

The possibilities of the situation have been further indicated by the action from time to time of the organised forces of Post Office servants. The Spectator stated the position in this respect very clearly in its issue of July I , 1908, when it said concerning the Post Office employés :-

These men possess a powerful organisation, which is admittedly devoted to the sole purpose of improving the financial position of the postal servants at the expense of the taxpayer. With this object in view, the organisation brings pressure to bear at every contested election, and Members of l'arliament are induced to make promises which can only be redeemed at the cost of the Exchequer, solely to obtain the votes of a body of men who are indifferent to ordinary political issues. Already many politicians are gravely regretting that the House of Commons did not support Mr. Gladstone and Mr. Disraeli when they had the foresight to join in proposing that Civil servants should be disfranchised. It is impossible to contemplate without the gravest alarm the prospect of a vast new body of State employés directing their votes on the same cynically selfish principles as actuate the postal servants.

How the organised pressure here spoken of operates in actual practice was shown in the House of Commons on July 16, 1908, when, after the Postmaster-General had made his annual statement - in the course of which he showed that the advances in the rates of pay, to meet the recommendations of the Hobhouse 
Committee, would result in an ultimate increase of $\mathcal{E}_{\mathrm{I}}$, ooo, ooo a year in the cost of workingone member after another rose to bring forward complaints from Post Office servants, mainly in his particular constituency, six hours of the sitting being thus taken up, apart from the time the Postmaster-General had occupied with his opening statement. Mr. Stuart (Sunderland) spoke of it as " a remarkable debate," and it is certainly doubtful if $M$. Peschaud could find anything more remarkable in the records even of the Belgian Chamber in regard to the State railway servants of that country. The Postmaster-General himself raised a mild protest, for in winding up the debate he asked the members " to look at the scheme as a whole, and not to think so much about constituents as about the service generally." The Globe of July i 7, 1908, was in no way too severe in its comments on so deplorable an exhibition when it said :-

It is high time that this form of log-rolling and axe-grinding should cease. It is as derogatory to Parliament as it is damaging to the public service that members of the House of Commons should permit themselves to become mere delegates and mouthpieces of certain sections of their constitutents who happen to be highly organised bodies, able and prepared to visit their displeasure upon a recalcitrant member at the next election. There can be no question that the votes of Post Office servants at the polls in 1906 were largely cast against the late Government because they had not seen their way, in the interests of economical 
administration, to sanction all the demands made upon them. This suited Mr. Buxton's party very well then, and they profited by it, but now that he is Postmaster-General he finds even his complacency must have its limits, if the profits from the postal service are not to be reduced to a vanishing point in obedience to the clamorous demands of Radical members pressed very largely in support of their own election interests.

RAILWAY MEN AS STATE SERVANTS.

But the question which really concerns me here is:-Looking at the example offered by the Post Office servants and the influence they can bring to bear on M.P.'s in furthering their own purely personal advantages, what would be the position when we had a body of over 600,000 State railway servants, including a very large proportion of electors, able to exercise alike on indiridual members, on Ministers, and on Parliament itself a degree of pressure probably far in excess even of that of the Post Office servants themselves?

Under our present system of representative government, the railway electors-especially in what are known as railway towns-would be able alike to return more men of their own class as M.P.'s; to influence candidates or members anxious to secure or retain their support; and, either through them or in other ways, to exercise considerable influence on a British Government doine all it can to please the electorate and make 
its own position secure. The strength of the railway men's position in having the right to elect, or, at least, to vote for their employers, would also be increased by the weakness of the Government in having to depend for their continuance in power on the favour of Parliament-a position not recognised in Prussia, a country whose State railway system is always held up to us as an example to follow.

Such possibilities as those here indicated would be, indeed, a source of danger to the interests of the nation, and it would become a matter for very serious consideration whether a resort to nationalisation would not have to be accompanied by some change in our electoral system, or, at least, by some interference with the degree of freedom with which railway men in the United Kingdom can, under existing conditions, take part in political questions.

VIEWS OF MR. WINSTON CHURCHILL.

As bearing on this point I would recall the fact that in January, 1907, Mr. Richard Bell wrote to Mr. Winston Churchill, who was then Colonial Under-Secretary, expressing the apprehension of members of the Amalgamated Society of Railway Servants on account of a circular issued by Lord Selborne to the Government railway workers in the Transvaal, prohibiting them from participating actively in 
154 Rail.wais and Nationalisation.

electioneering, or from standing as candidates for the Legislature. In his reply to this communication Mr. Churchill said :-

It is very natural, and, in my opinion, very proper, that British railway men should watch with vigilance over the interests of their comrades in similar employment in South Africa. There is, however, no ground for anxiety.

It must be remembered, first of all, that the Transvaal railways-unlike. British railways-are owned and worked by the Government, and that those who are employed upon them are not the servants of private companies but of the State. It has long been held undesirable that regular Government servants should conspicuously take sides in party politics, and, in consequence, the railway servants in both the neighbouring self-governing colonies of Natal and the Cape are expressly forbidden to do so. Indeed, the circular which Lord Selborne has issued makes rules which are less stringent than those enforced in these two colonies; for whereas in the Cape and in Natal Government railway servants are not allowed to join any political association, they will, in the Transvaal, under the circular, be allowed not only to do so, but even to sign requisitions to candidates. It is only prominent political activities that are denied them so long as they continue as Government servants to draw Government pay; and I think that such a restriction is at least as much in their own interests as in those of the public service generally.

Wherever State servants take an active part in the warfare of political parties there is always the danger that triumphant political parties will try to job their own supporters into positions of profit and trust and to exclude their opponents. Such a system has $b \in \in n$ found everywhere to be fatal to good government, and we should certainly not be justified in 
doing anything to introduce it into those new colonies for whose fair start we are responsible.

Granting that there is "no ground for anxiety" on the part of British railway men at present, the question is whether the conditions referred to by $\mathrm{Mr}$. Winston Churchill, now President of the Board of Trade, would not arise when the employés of the railway companies became " regular Government servants," and whether precautionary measures of the type in question would not be as excusable, if not as necessary, here as Mr. Churchill shows them to be in South Africa.

\section{TRADE-UNIONISM AND STRIKES.}

There are other directions, besides, in which the liberties of railway men might have to be curtailed on their becoming State servants.

In referring, at Liverpool, to the railway controversies in the autumn of $190 \overline{7}$, Sir John Gorst said, " Nothing but the energetic interference of Mr. Lloyd-George prevented a national railway strike because the railway directors were so foolish as to attempt to run a tilt against trade unions." Are we to assume from this that if the policy of nationalisation which Sir John Gorst recommends were carried out, the Government would themselves refrain. from any such attempt, and would give to railway men's trade unions, on their threatening to strike, all the " recognition" 
i56 Railiways and Nationalisation.

and power of intervention and control they wanted?

I will not stay here to discuss the certainly debatable point whether the policy of bluff and intimidation adopted by the Amalgamated Society of Railway Servants in their 1907 campaign would really have led to a strike of grave proportions, had it not been for the intervention of the Board of Trade, as Sir John Gorst quite gratuitously assumes. But let us take it, for the sake of argument, that the position was precisely as Sir John describes. IVe get then the fact that, whereas the President of the Board of Trade was able to intervene between the railway companies and a dissatisfied section of their servants, there would have been no one in a corresponding official, but independent, position able to intervene had such a dispute arisen on British railways owned and operated by the State. The Government, as one of the parties concerned, could not have assumed the rôle of arbitrator or mutual friend; and although, it is understood, the railway companies themselves were fully prepared, in 1907, to risk the threats of an extremely problematical strike, and to meet any possible contingencies, rather than make the surrender demanded of them, it is very doubtful if the Government, having regard to the exigencies of the political situation, would have been equally firm had the railways been State-owned and State-operated. In any case, it is most undesir- 
able that the Government of the country should have to run the risk of drifting into so anomalous a position.

To illustrate the situation in which Governments and the community may alike find themselves placed on the occurrence of an actual strike of railway men, I would offer three typical examples, drawn from Hungary, Holland and Australia respectively.

A WAGES STRIKE IN HUNGARY.

The State railways in Hungary have a personnel of about 60,000 officials and employés, and among these there existed in the early part of 1904 considerable dissatisfaction on the subject of salaries and wages, the discontented including not only drivers, firemen, platelayers, etc., but stationmasters, telegraphists and others. The Government brought forward a measure for increases to a total of about $\mathcal{E}_{\mathrm{I}} \mathrm{oo}, \mathrm{ooo}$ a year; but the prime movers in the agitation declared that for the lower ranks this amount would allow of an advance of only about eighteen shillings a year, and the offer must, they said, be rejected. They summoned a meeting of railway men to be held in Buda-Pesth, and, on the authorities prohibiting the gathering, a strike was threatened by the two chief leaders, stationmasters near the capital. These two were suspended, and on the evening of April ig they retaliated by de- 
claring a strike of all State railway employés in Hungary.

The order thus given met with an instant and widespread response. The telegraphists circulated the command, and then went home. From that moment, wherever news of the declaration of war was received signalmen left their boxes, engine drivers and firemen-mostly at midnightgot down from the locomotives of trains which had not yet reached their destination, the other grades left off work, and hundreds of passengers found themselves stranded at wayside stations, with no chance either of getting further that night or of communicating with anxious relatives and friends. The disregard of public interests was absolute, and this, too, although the railway men in the State service had, on appointment, taken an oath not to absent themselves from work without permission, while, under Article 480 of the Criminal Code, they were liable to three years' imprisonment for leaving the service without giving notice.

The only trains allowed to pass on the 19th were the up and the down Orient Express. When the driver of one goods train approaching Buda-Pesth showed an inclination to proceed in spite of the strikers, several hundred of them lay down on the rails, and declared that the train could only pass over their bodies. Thereupon the driver gave way. On the 2oth a few trains were run with the help of some retired railway 
veterans and others; and on the 21 st the Prime Minister said in Parliament:-

It is a pity that our sense of humanity is against meting out due punishment to those who were unfaithful to their oaths and to their duties, or, at least, to the ringleaders, who are well-salaried men, and ought to have known better; but we have adopted the principle of full pardon for all, provided the strike is immediately ended. In order to facilitate this we have allowed a meeting of men to take place to-day at Buda-Pesth, and shall allow the formation of a union of State railway men, with as many branches as they like to have. Should legitimate objections then be raised against the Bill now before the House, they will be duly considered. But the men must not think that we are forced to give way. We can resume traffic without them, and we have thousands willing to fill the places of those misguided men.

The negotiations thus opened broke down on the $23 \mathrm{rd}$, when the strikers presented an ultimatum declaring that their full demands as to pay and conditions-involving an increase in the working expenses of $£ 440,000$ a year-must be conceded within 24 hours. The strikers evidently regarded themselves as masters of the situation, and there seemed to be some reason for their impression. Not even milk and meat trains could get through, and the price of provisions in BudaPesth had already increased by from 25 to 50 per cent. Valuable racehorses had been left to themselves "somewhere down the line"; 300 wagons loaded with meat for export remained at 
Belgrade, unable to get away, while passive developed into active resistance when malicious damage was done to such an extent, in certain districts, in the way of tearing up lines, cutting telegraph wires, and rendering instruments unworkable, that, according to the director of the State railways, it would take six weeks to do the necessary repairs. The fact should be mentioned, also, that throughout the dispute the strikers received direct encouragement from the sympathetic attitude of the Opposition parties in Parliament, and especially of the Clericals.

In Hungary, however, the Army forces include a "Railway Regiment" of about 2,00o men, and on April 23 and 24 travellers in Hungary saw military officers in uniform acting as stationmasters, and soldiers in uniform doing the work of engine drivers, guards, pointsmen, telegraphists and even porters. The Government, too, were able to play a master stroke which brought the whole trouble to a somewhat dramatic close.

In the " camp" which had been formed by the strikers there were a large number of reservists who had joined the railway service after leaving the Army, and the Government threw a bombshell among them in the form of an Army. Order calling up all these reservists, so as to compel them to perform under a military régime the work they would not do as civilians. Disobedience to such a summons constituted an offence against military discipline punishable with imprisonment 
up to ro years; and violent resistance to superiors engaged in carrying out the Order would be an offence punishable with-death, by shooting!

So those of the strikers who were reservists had no chance left; and when, as the Army Order was read to them, they saw their camp entirely surrounded by military and police, they did not want to resist, or even to disobey. 'They returned at once to their duties, the camp was broken up, and on the $25^{\text {th }}$ the railway strike was practically at an end; though the Socialists tried for some days longer to foment a general strike of all industries throughout Hungary in revenge for the Army Order, which, they declared, " trampled on the freedom of the workmen."

British railway men will see from the story here briefly told that State ownership does not necessarily mean satisfactory conditions for the workers, while there is a suggestion that "all grades" really were affected in the troubles in question, considering that even stationmasters played the rôle of ringleaders. British traders and travellers, in turn, will see that a railway strike may just as readily occur under State as under company ownership. They can also speculate on what would happen in the event of such a strike as the one in Hungary being declared under conditions of State ownership of railways in the United Kingdom, where the final expedient so successfully resorted to by the Hungarian Government would not be possible. 
Would our own Government at least form a "Railway Regiment" in connection with British State railways? This is done not only in Hungary but in France, where (although the proportion of State-owned to company-owned lines is so small), a certain section of the State system is operated exclusively by a constant succession of military officers and soldiers, who thus acquire a practical knowledge of railway working, and to-day represent, in the aggregate, a considerable force of railway reservists available in case of need.

\section{A “ SYMPATHY STRIKE" IN HOLLAND.}

The strike of railway men in Amsterdam in January, 1903, causing an entire suspension of the railway traffic there for one day, was due, not to any personal grievance of the railway employés themselves, but to their "sympathy" for another body of men, namely, the dock labourers. The latter had already gone out on strike, and, finding that their places were being filled up by outsiders, they made overtures to the Railway Employés Union to help them. Thereupon this Union approached the managing directors of the Dutch Railway Company and called upon them not to convey by trâin any goods which had been handled in the port of Amsterdam by non-union labour. The Company for the Exploitation of the State Railways 
were also concerned in the matter. The two companies approached the Minister of Commerce at The Hague, and pointed out to him that compliance on their part with the demands of the men's leaders would involve a breach of one of the main conditions of their own agreement with the Government, namely, that the companies were bound to accept goods for transport by whomsoever offered. They therefore asked the Minister whether, if they surrendered to the men, and thus avoided a possible dislocation in the railway service, he would free them from responsibility for default of their agreement. The Minister replied that he was unable so to do, and that, inasmuch as they were private companies, they would have to accept full responsibility for whatever they did.

At first, therefore, the companies refused to give way to the men, who, carrying out their threat, struck work in Amsterdam on January 30 , and were joined by the large body of municipal workers employed on the various enterprises owned by the city. The companies then said to the Government, "If you will strengthen our hands with police and troops, we will attempt to go on." But there were not sufficient troops at once available; the merchants and traders began to give notice that they should hold the companies responsible for all delays in delivery, and, in the result, the companies surrendered to the strikers on the 3 Ist, agreeing to boycott the 
i64 Railiways and Nationalisation.

traders who had had the temerity to employ nonunion labour.

The Government realised the gravity of the position thus brought about, and in the following April they introduced into the Second Chamber of the States General an Anti-Strike Bill which, among other things, made it unlawful for any railway employé so to act towards another as to interfere with the working of the lines, and provided for the punishment of railway men going out on strike. The main purpose of the measure, as explained by Dr. Loeff, Minister of Justice, was " to separate evilly-disposed workers from the loyal section, in order to prevent the recurrence of strike agitations based on Anarchist movements."

The introduction of the Bill led the body known as "The Committee of Defence" to proclaim a general strike throughout Holland, not alone of railway men, but of workers in all trades and industries. The bakers, especially, were called on to show their "sympathy" with the railway men, just as the latter had already given a proof of their sympathy with the dock labourers; the diamond workers did respond, and so did some of the gas workers. On the other hand the power of the strikers to interfere with the railway operation was now decreased by the fact that all the railway stations were occupied by troops, while sufficient of the railway men remained loyal to allow of a restricted 
service of trains being run, though every train carried a military escort, by way of precaution.

The Second Chamber passed the Anti-Strike Bill on April 9. It then went through the First Chamber and became law within two days; but the railway men had, in the meantime, abandoned their own strike and the Defence Committee their general strike. As a set-off to the very stringent enactments of the measure, the Government undertook to revise the wages and labour conditions of the railway workers, complaints in relation thereto having been made in connection with the second series of troubles. But a still further event which happened-and one that is especially noteworthy in view of what I have already said concerning the strike in Hungary-was that during the debate on the Anti-Strike Bill, the Second Chamber authorised the Government to establish, in connection with the Army, a Railway Brigade which would be able to operate the railways in the event of any further strikes occurring.

\section{LABOUR $\%$. GOVERNMENT IN VICTORIA}

Wages and general conditions of employment had no direct concern with the strike of railway servants that occurred at Melbourne, Victoria, in May, 1903. The event was, rather, a struggle for supremacy waged against the Government, through the instrumentality of the 
railway employés, with the design of enabling organised labour to become the dominating factor in Victorian politics. It was, in part, a case where State servants were made use of for promoting what the Premier, Mr. Irvine, described as " a long-meditated revolt against established authority," and the issue of which, in his opinion, concerned " not only Victoria but every other country.'”

The political organisation of labour in Victoria had been steadily proceeding for some years prior to 1903 , as, indeed, had been the case in other Australian colonies besides. At the same time the public services were becoming more and more overmanned, each succeeding Ministry, as it came into power, having to distribute jobs among crowds of supporters expectant of rewards for services rendered. The public expenditure was advancing rapidly, and it began to look as if the railways, especially, were to be operated in the interests far less of the colonists than of the actual or prospective railway workers. Attempts were made in Victoria to secure a more economical system of operation, but they were frustrated by the organised forces of the railway men, who, in turn, had the powerful support both of the Labour Members in the colonial Parliament and of the "Melbourne Trades Hall," a federation of the labour unions of the colony with which the railwaymen's societies were in close alliance. Not only 
were all attempts at retrenchment in railway operation frustrated, but the railway men, with their influential backers, sought practically to fix their own conditions of service. There was, also, the danger that if the association between the Trades Hall and the railwaymen's unions continued, the latter might be called upon (as, I have shown, actually happened in Holland) to take part in some dispute with which they had no direct concern. The aims of the Trades Hall itself were avowedly as much political as they were economic, and the whole position constituted a source of no little danger to the political and economic interests of the colony.

In the result the Railway Minister informed the railway men that, while he did not object to their having unions of their own, they must sever their connection with the Trades Hall. They refused, and thereupon the Prime Minister assumed the lead, and gave notice that unless the four railway unions affiliated with the Trades Hall withdrew therefrom on or before the 12 th of May, the whole of their executive officers would be suspended. At the same time he summoned the State Parliament to meet to deal with the threatened emergency. The men replied, on May 8 , that unless by five o'clock that day the Premier withdrew his demand, the engine drivers and firemen would go on strike at miclnight. The Premier did not withdraw, and the strike began at the hour stated. 
To fight the battle thus proclaimed the railway unions had $£ 70$,ooo of their own, and they were able to rely on obtaining a further $£ 30,000$ from other unions. But what they mainly depended on was the great amount of inconvenience and loss to which the public in general would be put through a complete cessation of railway communication in and around Melbourne. For some days practically no trains-certainly no goods trains-ran, and communication with suburban and country districts ceased. The mail services were disorganised, factories and business places had to close, thousands of workers were thrown idle, and food and other necessaries rose to famine prices. But the very completeness of the strike was the undoing of the strikers.

The citizens rose almost as one man against those who had not only shown no consideration for the public interests, but had abused the power placed in their hands, had committed a breach of trust, and had even sought to exploit the public inconvenience to serve their own personal ends. So another battle cry now arose, and that was one of "No surrender to the strikers!" Retired railway servants, with work still left in them, turned up in hundreds; drivers of mining engines offered their services; 800 artisans skilled in machinery wanted to know if they could help; mining students at the Melbourne University entered upon the duties of locomotive firemen with all the energy and enthu- 
siasm of youth; other of the students became special constables; merchants, tradesmen, clerks and others volunteered to act as foremen, or in other capacities; while the citizens generally kept in the best possible spirits, and were prepared to tolerate anything rather than let the railway men win. "Never," said the Melbourne correspondent of the Standard, writing at the time, "was so universal and almost instantaneous a demonstration made against a revolt." The strikers certainly did their best. They removed engine fittings; they greased the rails; they tampered with the points; they threw soap into the boilers and oil on the locomotive water, and they adopted other little devices besides. But it soon became evident they were playing a losing game.

Parliament met on May 13, when the Premier introduced a most drastic Anti-Strike Bill. Railway men leaving their work without giving fourteen days' notice were made liable to a fine of $£$ Ioo, or one year's imprisonment; they were, also, to lose their pensions, and be disqualified for future employment by the State. The Bill further empowered the Railway Minister to fill up the places of the strikers, by appointing other men under a two-years' engagement, and to take measures for the protection of the new hands; it imposed penalties on persons who interfered in any way with railway workers; the collection or the distribution of funds for the strikers was 
declared illegal; the police were authorised to destroy all printed documents in support of the strike; and they were to disperse any assembly of strikers attended by more than four persons.

Severe in the extreme as the proposals of the Bill were, appearances showed that the measure was certain to pass, more especially as it was to be operative only so long as the strike lasted. An overwhelming determination prevailed both inside and outside the House that the Government must be supported. But there was no need for the Bill to go actually through. On the evening of the second day after the introduction of the measure the strikers were assembled at one of their nightly entertainments, listening to speeches by leaders who assured them they were "winning all along the line," and to songs by leaders' wives who sought to keep them in good spirits, when some one came in and announced the fact that, a complete surrender to the Government having just been made by the leaders-inchief, "the strike was off." And so, for that night, was the harmony.

Following on this outcome of the trouble, the colonial Parliament passed a Constitution Act Amendment Act which, among other things, deprived railway servants of the right to vote for any province or district; required that they should be included in a separate and distinct register; and authorised them to elect from such register one person to represent them on the 
Legislative Council, and two as their representatives on the Legislative Assembly. A later Act, passed in 1906, repealed the separate representation of railway servants thus set up, and substituted a provision to the following effect :-

4. (I.) In order that all officers may be enabled to render loyal and efficient service to the State, it is hereby enacted that no persons or class of persons employed in any capacity (whether permanently or temporarily) in the public service (including the Railway Service, the Police Force, the State Rivers and Water Supply Department, and the Lunacy Department) shall either directly or indirectly take any part whatsoever in or in relation to elections of members of the Legislative Council or the Legislative Assiembly, or directly or indirectly in any way take part in the political affairs of the State of Victoria otherwise than by recording a vote at a Parliamentary election; and no person or class of persons so employed shall directly or indirectly use or attempt to use any influence in respect to any matter affecting the remuneration or position in the public service of either himself or any other person.

(2.) If any person so employed is guilty of any contravention of this section, then on proof thereof to the satisfaction of the Public Service Commissioner, the Commissioners of Railways, the Chief Commissioner of Police, or the State Rivers and Water Supply Commissioners, or the Inspector-General of Insane (as the case may be), such person may, by the said authority, be fined any sum not exceeding ten pounds, and may be reduced in class, subdivision, grade, or status and salary, or he may be dismissed, or his services may be dispensed with, provided that such person shall not be dismissed or have his services dispensed with for any con- 
travention of this section without the consent of the Governor in Council.

FURTHER POSSIBILITIES.

Reverting to the conditions in the United Kingdom, I would suggest that there are still wider possibilities here of labour troubles for the Government in the event of their undertaking a policy of State-ownership and Stateoperation of the railways than have yet been suggested.

"Manufacturer," writing to the "Engineering Supplement" of The Times of May 3, 1908, criticised the policy of English railway companies in manufacturing their own requirements, and, alluding to the "huge establishments like Crewe and Swindon," continued : "I feel that the capture of these establishments is at the bottom of the Radical or Socialistic cry for the nationalisation of the railways." Such capture would certainly be another step forward in the nationalisation of "all the means of production;" but for the labour unions it would mean something more. The president of the Newcastle-upon-Tyne Association of Students of the Institution of Civil Engineers, Mr. J. D. Twinberrow, in his address at the opening of the 1907-8 session, referred incidentally to the nationalisation of British railways, which he spoke of as " a means towards securing a cheaper and better service for the public and increased 
remuneration (with less labour) for the railwayman," and added :-

The spokesmen of Labour welcome nationalisation as a means to check the introduction of laboursaving devices, and to prevent the adoption of machinery of greater earning capacity, the skill of the workman being defined as a constant quantity not susceptible to improvement by the experience of each succeeding generation.

It might be, therefore, that the policy of capture spoken of by "Manufacturer" would have to be considered in conjunction with a policy of checking and restriction, if these two authorities are both correct in their anticipations.

We do, at least, get this undeniable position : If the Government bought out the railway companies, the "huge establishments" in question would have to be included in the deal; and if the Government decided to retain them, and carry on the processes of manufacture there, as before, they would be brought into direct relations with the unions, not alone of the regular railway servants, but of the engineers, the boiler makers and the many other branches of labour which the establishments in question comprise. Even, therefore, if the Government avoided complications with the Amalgamated Society of Railway Servants, they might still be concerned in disputes with some of these other labour unions, or, through them, be involved in "sympathy" strikes arising out of troubles in industries with which they had no concern whatever. 
i74 Railivays and Nationalisation.

Nor do we get to the end of the story even here, for one may further ask,-If the Government had already taken over the railways, would they have been quite so ready as they were to yield to political pressure in that matter of the Miners' Eight Hours Bill? How the railways are concerned therein is shown by a statement issued by Mr. W. Temple Franks, secretary of the Railway Companies' Association, and published in the Railway News, from which I learn that in 1907 the railway companies consumed I6, IOI,000 tons of coal (including I 2,093,890 tons used for locomotive purposes), and that even a is. rise in price per ton on the former figure would amount to about f.800,000 per annum.

It is significant that when $\mathrm{Mr}$. Gladstone moved the second reading of the Bill, on June 22, I908, and, in the course of his speech, asked "What was the reason for this Bill?" there were responsive cries of "Votes!" Personally, I am disposed to agree with the interruptions; though it was really a matter not only of getting votes, but of securing them at the expense of the railway companies and others. One may, however, doubt very much indeed if Mr. Gladstone would have had so free a hand if the railways, whose working expenses may thus be increased by at least $f, 800,000$ a year as the result of the measure, had been owned and operated by the State, under the watchful eye of the Chancellor 
of the Exchequer. In this instance nationalisation might have taught the Government a useful lesson. But, politically, it would have made their position still more complicated.

So, from the point of view alike of the railway workers, of the Government, and of the public, the complicated labour problems involved must be regarded as constituting a very important phase indeed of the whole nationalisation controversy. The nationalisers are disposed to make light of them, and Sir John Brunner, in a letter to The Times of May 25, 1908, even went so far as to say: "A general railway strike ought to be made, must be made, an impossible thing. Through nationalisation it can be made as impossible as a general strike of the Territorial Army." To what extent this latter assertion agrees with actual facts may be judged by the reader himself on the basis of the stories told in the present chapter. 
i 7 Railuays and Nationalisation.

\section{CHAPTER IX.}

\section{STATE v. COMPANY MANAGEMENT.}

Are there any special merits in State management which render it superior to management by commercial companies, and have the public reason for expecting really substantial benefits through substituting the one for the other?

Here, in the first place, I think it only right to combat the suggestion so of ten advanced by the nationalisers that railway companies consist of representatives of private enterprise who are free to exploit the requirements and the convenience of the public solely in the interests of dividends. Do railways really come within the definition of " private enterprise?" They are certainly created and operated with the money of private individuals, and the loss, if any, falls upon the investors; but, apart from this material consideration, British railways are subject to the most thorough-going public control, in the public interests, without having, in return, any of the possible advantages of public ownership.

\section{STATE CONTROL.}

In one sense railway companies are traders, since they provide, and sell at a profit-when 
they can-a certain commodity, known as transport. But they occupy a position entirely different from that of any other body of traders. They cannot construct their lines until Parliament sanctions their schemes and approves their proposed routes, after having given an opportunity to everyone interested to raise objections, should he think fit. The lines, when completed, must in turn be approved by the Board of Trade, which body requires that everything shall be perfect from the start in every possible detail. The Board of Trade, again, has very wide and almost drastic powers of supervision and control in regard to safety appliances, operation of the lines, hours of railway men, etc.

Parliament itself fixes the maximum rates a railway company may charge, and if a company should increase any rate-even though the amount to which it is raised remains well within the Parliamentary maximum-the company may be called upon to justify such increase to the Board of Trade, or, if necessary, before the Railway and Canal Commissioners.

On this subject of State control I might recall some observations in the report of the "Railway Conmission" appointed in I865, with the Duke of Devonshire as chairman :-

It is of no slight importance to the public that railway companies should be compelled to apply to Parliament for its sanction to every alteration of, or addition to, their undertakings, and that any 
other railway company or person affected by the change should have the liberty of being heard in opposition.

The railway companies being thus continually before Parliamentary committees, either to defend their interests against invasion or to obtain further concessions from Parliament, an opportunity is afforded to the public of bringing forward any grievances from which they may suffer, and to Par. liament of imposing such fresh regulations as the public interests may require, as a condition of the new concession.

Thus Parliament becomes an arbitrator between the railway companies and the public, and the railway companies voluntarily accept its decisions to promote their own objects or interests. This operates as a powerful inducement to the companies to remove any grievances of which the traders in their different districts might complain.

The position to-day is stiil the same. The State can exercise absolute control without experiencing the disadvantages and financial risks attendant on actual ownership, and the public have the benefit of such control without any fear that if the railways do not pay the taxpayers will have to make up the deficit. It is the railway shareholders who stand to lose by reason of the control from which the community benefit.

\section{RAILWAY ACCIDENTS.}

Should any accident occur on the railways, a most searching investigation is made by Government officers appointed for that purpose, and the public have an absolute guarantee that every 
possible inquiry will be made, or step taken, that may bring to light either careless operation or hidden dangers.

Would there be, under a system of State ownership and operation-when one Government official might have to sit in judgment on another - the same guarantee of safety for the public that there is under the rigid control and supervision enforced by the State against the railway companies? Would there not rather be a tendency for this control and supervision to be at least weakened when the railways passed over to the State, and might not the result be an actual increase in accidents rather than a reduction below their already comparatively small proportions?

There is certainly not much encouragement in this direction to be derived from the experiences of State ownership and operation in Belgium. In a despatch published in The Times of June 14, 1908, the Brussels correspondent of that journal, referring to an interpellation to be addressed to the Government on the subject of recent railway accidents in Belgium, said:--

Since May 19, I find, by collating various reports, that no fewer than fifty-six persons have been killer and 356 injured. No doubt these figures are exceptional, for they include the Contich collision, in which forty persons lost their lives and, as it now appears, 230 were more or less seriously hurt; and the failure of a train to stop before reaching the buffers in the Midi Station, whereby about forty 
workmen were injured. But, making every allowarice for human stupidity, and without attempting to prejudge the result of inquiries still proceeding, there is clearly ground for demanding a serious investigation into the causes of the incessant rain of ninor accidents with which the State railways have been afflicted. . . . Regulations, however perfect, will not prevent the failure of a brake or brain to act; but the question is whether the State administration spends the necessary money and takes the necessary pains to secure that degree of intelligence among its cmployés without which the finest regulations ever framed merely produce a false feeling of safety.

Nationalisers in the United Kingdom rarely fail, in their speeches or writings, to point to the low fares at which one can travel in Belgium as a striking proof of the blessings of State ownership and operation of railways. But, judging from what The Times correspondent says, there is another side to the question as well.

THE ALLEGED " CONFLICT OF INTEREST."

In the circular issued announcing the formation of the Railway Nationalisation Society, it was said :

In some countries the law prescribes that the railways shall subserve the common interest. In this country they are frankly run for private profit. The result is a conflict of interest between the railway proprietors and the public.

Many other enterprises in this country besides railways are frankly run for private profit. 
Steamship companies work for private profit. So do the companies operating iron and steel works. So do manufacturers, tradesmen, agriculturists and market-gardeners who supply us with out daily wants. So do theatre lessees, actors and musicians who provide us with recreation. None of these are subject to a State control anything like so rigid as that which is applied to railways; yet who suggests that there is a conflict of interest between all these persons and the public simply because of this element of private profit? 'The existence of this very element is only a direct incentive to study, anticipate, and provide for the wants and wishes of the public in order that the desired profit may be secured.

Instead of a conflict of interest there is a community of interest; and what is true of these traders and others here in question is equally true of railway companies themselves - but with this difference, that the railway companies are rigidly bound down to study the public interests to an extent unsurpassed in any other undertaking; while, unlike other traders, they are not free to raise the price of the commodity they sell, however high the cost of production (in the shape of working expenses) may go up, or whatever may be the exactions made upon them by Imperial or local authorities. 
ENGLISH AND FOREIGN LINES COMPARED.

I Iad the alleged conflict of interests between the railway proprietors and the public really existed, the former would have failed to show adequate enterprise and foresight in making provision for the requirements of traders and travellers. Ilave there been shortcomings in this respect on the part of railway companies here, as compared with State railways abroad?

For an answer I turn to some remarks made by Sir Robert Perks during the course of the debate in the Ilouse of Commons on Mr. Hardy's nationalisation resolution. He said, among other things :-

Neither of the two underground railways in London had a single penny of watered stock in their capital, and one of them had carried more than the entire population of the globe in the last thirty vears without any return whatever to the ordinary jroprietor. That might not show much sense on the part of the proprictors, but it certainly showed the sacrifice that had been made for the benefit of London. . . . If our privately managed railways were compared, in the matter of passenger scrvice, with State-controlled railways abroad, it would be found that the foreign railways were slower, dearer, and afforded fewer comforts and facilities, especially with regard to third class passengers, who constitute go per cent. of the travelling public in this country. Let them take, for instance, the lines between London and Edinburgh. We had twenty trains a day running between London and Edinburgh, and third-class passengers travelled by every train. An Hon. Member below the gangway 
wanted to go even further, and provide third class sleeping carriages. There were only seven express trains which ran between Paris and Marseilles, as compared with twenty running between London and lidinburgh. There were fifty express trains a day going out of Paris in all directions-to Germany, Belgium, Austria, Italy, and various other places, and there were only four of these which carried third class passengers, whereas our trains carried third class by almost every train. Then, let them mark the very slow delivery of goods on the Continent compared with the rapid delivery here. The arrangements for through rates and transit were most insatisfactory on the foreign lines. There were many works in Alsace-Lorraine which could not get their coal and ore simply because the State railways refused to make through quotations. There were railways in this country which had made unfortunate speculations in connection with the outlay of huge sums of money. For example, out of f, 16,000,000 or $\mathcal{E}_{17}, 000,000$ recently expended on the underground lines of London, at least tis,000,000 were at present wholly unremunerative. That was one of the risks which the nation ought not, and, probably, would not undertake, and the result would be that necessary lines would not be built. Another great railway had spent f,6,00o,ooo or $\notin 7,000,000$ in giving a new competitive service to London. Nearly the whole of that capital was unremunerative.

Here we get absolute proof that company ownership of the railways has indeed sought to "subserve the common interest," even though it may not have always succeeded in furthering its own. That the State would have done more for the public, or would even have 
184 Rail.ways and Nationalisation.

done as much, is distinctly doubtful; while if the State were substituted for the companies there would be two interests involved just the same as at present. Should the State turn trader, that is, become a dealer in transport, it must necessarily demand payment for that which it sells. It will still be to the interest of the Government (especially if operating on Prussian principles) to get as good a return from the railways as they can; and it will still be to the interest of the trader to try to get transport from them at as low a price as he can. To this extent, therefore, and so long as there are two parties to a bargain, the "conflict of interest" in a matter of buying and selling will not be got rid of merely by a change of proprietor; and it is open to serious consideration whether a Chancellor of the Exchequer might not be quite as keen after railway profits to add to his Budget as any of the existing companies could be for dividends to pay to their shareholders.

\section{INITIATIVE AND ENTERPRISE.}

It may be doubted, also, whether a State railways department, operating the entire railway system of the United Kingdom, would show quite the same degree of initiative, energy and enterprise in catering for traffic as is displayed by the existing railway companies in competing for traffic so actively as they do one with another. 
The essence of State management is routine; the fundamental principle of commercial management is enterprise. The State official with a fixed salary and a secure position does the work that comes before him; but as a rule he has no particular inducement to show initiative in suggesting improvements, to display exceptional energy in getting through his work, or to put himself to any personal inconvenience in the interests of individuals or of the community. These qualities of initiative, energy and consideration are far more likely to be found in the servants of a commercial undertaking where every department must be kept in a condition of the highest efficiency to meet the competition of rivals, to cater for the requirements of the public, and to secure for the shareholders a fair return on the money they have invested.

So one might reasonably expect to find that when the State controlled all the railways there would be not alone an attempted economy in the matter of working expenses, when rail competition ceased and the Government could do as they pleased, but there would be also a pronounced falling off in that initiative and enterprise which, under a company régime, have done so much to improve the railway system, and have so greatly and in so many different ways afforded increased facilities to traders and travellers. 
TRAFFIC PRORLEMS AND THEIR SOLUTION.

Would State officials, again, be better qualified than the officers of the existing railways to deal with the problems that arise in the fixing of railway rates; and would traders find it preferable to deal with the former rather than the latter?

Some very pertinent observations on these distinctly practical points are made by Mr. W. A. Robertson, of the New York bar, in "An argument against Government Railroads in the Inited States," published in "The Annals of the American Academy of Political and Social Science" for March, 1907. Mr. Robertson said, among other things :-

To one who has never considered the subject, the intricacies of rate-making will prove a painful and rexatious surprise. There are so many different and discordant elements entering into the conditions that an exact solution is impossible. . . As observed by the Industrial Commission, in its report to Congress, "The conditions are highly complex, and no simple and general rules can be made to govern in all instances. The very complexity of the problem emphasises the necessity for general direction!'

The problem which a freight agent or traffic manager has to meet is so different from that which the public supposes, that it is hard to explain it in a few words. The picture that seems vividly portrayed upon the minds of most men in that of the general freight agent arbitrarily deciding upon whatever rate he deenus sufficient to pay for the " cost of service" (the cost of actually moving a ton 
of freight a certain distance), together with enough to cover the Company's taxes and the interest on the bonded indebtedness (which is generally. assumed to be needlessly and culpably large), and to pay dividends on an artificial and imaginary capitalisation. In reality, this sort of reasoning is putting the cart before the horse. The rate is really dependent upon conditions in the world of trade, the character of the commodity to be moved, the extent of competition from other carriers, either rail or water, and the possibilities of the development of a line of business or a section of country.

When the rate has once been made and the revenue earned, the next problem is the prosaic one -very familiar to every housekeeper-of adjusting expenses to income. The name of these expenses i; legion: The wages of labour and the cost of fuel and innumerable supplies are elements in the cost of conducting transportation. The maintenance of the roadbed and stations, and of the terminal facilities in great cities-these are elcments in the maintenance of the physical property of the road. New engines and cars and the repair of old ones make up the account called maintenance of equipment. The taxes due the State, and the interest on the bonded debt of the company, make up the company's fixed charges; charges which must be met if the corporation is to remain solvent. Then there is still the need of setting aside funds against the depreciation of the property, the maintenance of a surplus against hard times, and unlooked for expenses and emergencies; and, lastly, the raising of a net revenue for dividends, so that those who own the road may receive some return on their investment. All these varied expenses enter into the financial side of railroad management.

It is idle to imagine that officials or clerks in a Government burcau will be able to handle such 
questions as we have mentioned better than the trained, experienced and well-paid officers of a railroad. Nay, it is difficult to think of their being intelligently, speedily, and satisfactorily disposed of at all by any Government department. Whoever has had dealings with a great Government office knows the truth of these words.

Enthusiastic reformers cheat themselves into the belief that the weight of an enlightened public sentiment-the travelling and shipping public being brought in daily contact with the railroad-would compel an improvement in the conditions we have pictured. Has the weight of public sentiment ever permanently cured the lesser diseases of the body politic? Has it brought effectiveness, economy, and high character into the police, street, and water departments of our great cities? How often is a State capitol built within the appropriation? Have the taxpayers of New York ever checked extravagance and corruption on the Erie Canal, or taken that formerly useful artery of travel out of "politics?"

Even assuming that the tone of the public service can be made equal to that of an ordinary business hcuse, the question still remains why Government officials will be able to solve transportation problems better than private individuals. There is no magic in wearing the livery of Government, and no private fund of knowledge is at the disposal of its officials. They have no peculiar facilities for reaching correct conclusions. The problems will not be a whit simplified by placing the carriers in the hands of a Government bureau. The difficulties that now hang about the subject of freight rates are inherent and rest in the very nature of the service to be performed. Unless freight rates are to be prescribed on a blind, arbitary, and unreasonable basis, without regard to the real and ever-changing conditions of the business world, the same difficulties that now 
puzzle traffic managers, vex merchants, and assail railroad commissions and courts, will be present as surely and as potently under public service as under private ownership.

But to the mercantile community the transfer of ownership would be a change fraught with unending and incalculable mischief. If there is one desideratum for the shipping community and the world of trade it is a system of freight rates that shall be flexible and adaptable to the thousand and one varying conditions of business. We have lately heard so much about "stability of rates" and "maintenance of the published tariffs"-necessary and proper as these are-that we have almost forgotten that flexibility is as essential as uniformity. It is the glory as well as the weakness of our transportation system that it is peculiarly American, tıuly a plant of native growth, and that it has, on the whole, adapted itself marvellously well to the dcvelopment and unprecedented expansion of our country. This has resulted from a remarkable power of adjustment to local needs in a land where growth and change have been abnormally rapid. . . .

If in place of a management of this kind, at once both sympathetic and self-interested, the merchants had been obliged to meet the stolidity of a government bureau, its circuity of operation, the desire to postpone action till " after election," how different must have been their experience. Or, if they had bcen forced to deal with Congress, they might have seen the measure succeed in one House or before one Committee, only to be indefinitely delayed in the other House or in Committee of the whole, or played off against other interests in far-away sections of the country whose representatives demanded some quid pro quo for their support. They would then have realised the profound truth contained in the observation of a great modern historian, that the people's representatives and lawmakers have rarely 
accorded any great public privilege except under strong pressure.

Under present conditions, the aggrieved merchant rray always appcal from the railroad company itself to Government aid in some form. State and Federal commissions stand ready to adjust ratessometimes, indeed, with "a strong hand and a n!tultitude of people "- - and behind the Commissioners are the courts. Everybody is ready and willing to move against a railroad corporation. But let the Government once become the supreme monopolistic owner of the mightiest railroad in the world, and how feeble and helpless will be the shipper who pleads before some Government department for relief in freight rates, having nothing but the merits of his case to invoke in his behalf.

In confirmation of the views here expressed, I would further point to the report of the Commission appointed to enquire into the organisation and administration of the Central South African Railways, where it is said :-

The Commission have not inquired into the rates in force on the Central South African Railways, but there is evidence that these suffer from a rigidity common upon all State railways. Governments can never act with the same freedom as private individuals; but they can at least entrust the immonsely difficult business of rate making to experts, and leave them as far as possible unfettered.

\section{GOVERNMENT ROLTINE IN FR.INCE.}

For examples of Government routine in regard to requests from traders for modifications in railway rates, I shall content myself with references 
to two countries only, France and Prussia; and I invite British traders to make their own comparisons between the stories of circumlocution I shall narrate and their personal experiences in dealing with railway companies at home on like occasions.

In France the Minister of Public Works exercises an absolute control over railway rates and charges, whether on the State system (which is $I$, 800 miles in extent) or on the systems (having a total mileage of 23,800 ) operated by private companies. This control applies not only to any increase in rates, as against the trader, but also to any decrease proposed in his favour. The Minister of Public Works is, in fact, influenced by a two-fold consideration. In the first place he desires that the welfare of trade and commerce shall be safeguarded. In the second place he has to remember that successive French Governments have advanced a very large amount of the capital required for the construction and the maintenance of the railways, and that these are to become the property of the nation when the periods for which the concessions are granted expire. This will be between the years 1950 and 1960. It is, therefore, considered desirable that, in the meanwhile, nothing should be done which would depreciate the earning powers of the lines the State is eventually to take over, especially as the Government guarantee of interest might conceivably lead the companies to make 
experiments, in the way of rate reductions, from which they would refrain were they entirely dependent on the results of operation.

For this dual reason there is a most elaborate machinery which has to be set in motion before any changes in regard to domestic railway rates can be effected in France. Briefly stated, the process gone through is as follows :-

I. The traders concerned send a statement of their case to the railway company.

2. The statement is duly considered by the leading officials of the company.

3. Should the company consider that the claim made has been substantiated, they forward it to the Minister of Public Works, setting out the reasons for their own approval.

4. The Minister of Public Works directs that copies shall be forwarded to $(a)$ the Commercial Control Department for report; and $(b)$ to the prefect of each and every district through which the section of line to be affected by the proposed change runs; while notice of the proposal must also be given in the Journal Officiel, lest other districts interested in the matter may be desirous of expressing their views.

5. Each prefect is required to acquaint the local Chambers of Commerce with the proposal, and give them the opportunity of making their observations thereon.

6. Having been considered by the Chambers of Commerce, the proposal, with their observa- 
tions attached, passes on to the Inspecteur de l'Exploitation Commerciale de la Conscription, who next sends it to the Contrôleur Général, who in turn refers it to the official representatives of any maritime ports, navigable waterways, o1 mining districts affected.

$i$. From these individuals the proposal goes to the Inspecteur Général du Réseau; and it is gratifying to know that the real consideration of the matter is now about to begin.

8. With the observations of the various authorities through whose hands it has already passed, the proposal is submitted to the Comité Consultatif des Chemins de Fer, one of four such advisory committees operating in connection with the Ministry of Public Works.

9. The proposal is considered either by an individual member of the committee or, where the matter is of special importance, by a subcommittee appointed for that purpose, such subcommittee holding an inquiry of its own, should it think fit, and examining representatives either of the railways or of the traders on the points at issur.

Io. A report on the results of such consideration or inquiry is made to the Advisory Committee.

II. The Advisory Committee forwards the documents with a recommendation of their own to the Minister of Public Worlis.

I2. The Minister of Public Works now looks 
into the matter, and decides for himself whether or not the recommendation of the Advisory Committee shall be carried out, and the desired concession granted or rejected.

Questions relating to export freights may be settled in five days, while new rates for transit traffic whch might go through Holland or Belgium, and thus be lost to France, unless an immediate decision were arrived at, may be conceded within twenty-four hours. But in regard to domestic consignments by rail, a change in rates desired by the traders, and endorsed by the railway companies themselves-such a matter, in fact, as a deputation of traders might bring before a general manager here, and get disposed of in a twenty-minutes' interview, or thereaboutstravels in France through all this official routine, and it does so at a rate of speed which is essentially petite vitesse. The simplest matters will take several months to go the round, and I heard recently of a case where the securing of official approval of an alteration desired by certain traders, and favoured by the railway company concerned, took no less a period than two years.

\section{GOVERNMENT ROUTINE IN PRUSSIA.}

In Prussia, also, the Minister of Public Works is the final authority, whose approval must be obtained for all new rates or alterations of old ones. But, since 1895 , when the system then 
existing was reorganised, the responsibility of actually fixing and adjusting the rates-both for goods and for passengers-falls, together with administrative questions in general, on the twenty-one State railway directorates which divide between them, in clearly-defined areas, the 21,000 miles of the Prussian State railways. These directorates, however, are bound by law to consult a Circuit Advisory Council in regard to all questions of rate alterations. The Circuit Councils, of which there are nine, are composed of representatives alike of the railways, of the Chambers of Commerce and trade or agriculture organisations, and of the local commercial and industrial interests in general. Each has a standing committee which first subjects to an exhaustive examination any petition, request or complaint sent in by traders, and advises the Council thereon. The Circuit Council makes a recommendation, in turn, to the railway directorate, and this body is required to give careful consideration to whatever the Circuit Council may suggest, though it is not bound to concur therein. The directorate can also ask for the advice of the Circuit Council in regard to other questions in which the interest or operation of railways and traders are mutually concerned.

In addition to these Circuit Councils there is in Prussia a National Council which "advises" the Minister of Public Works in the same way that the Circuit Councils advise the directorates. 


\section{ig6 Rallways and Nationalisation.}

The National Council consists of forty members, of whom ten are appointed by the various Prussian State Ministers, and thirty are elected by the Circuit Councils, which choose for the purpose leading representatives of the various commercial and trading interests of their districts. Each member holds office for three years. The National Council deals with general questions or matters of policy in regard, not only to rates, but freight classification, budget proposals, etc., reporting thereon both to the Minister of Public Works and to the Prussian Parliament.

The routine gone through in Prussia in dealing with traders' petitions would appear to be less formidable than in France; but in practice considerable time is occupied by the deliberateness so characteristic of all State departments, and more especially marked in the case of a State railway, where, beyond the merits or demerits of any question as between the railways and the traders directly concerned, a variety of other conflicting problems arise, such as whether or not the State finances will permit of concessions otherwise perfectly warranted and desirable in themselves; and the balancing of either one set of political considerations against another, or the mutual claims of rival sections of the country all looking to one and the same authority for the furthering or the preservation of their interests. It is quite possible that on some such grounds as these a concession which 
would be readily granted by a railway company may have to be refused by a State railway.

The great advantages claimed for the systems in operation in France and Prussia are (I) that the railway officials and the traders are brought into closer relations, each being enabled to understand better the wants of the other; and (2) that traders have at their back official bodies which can exercise influence in support of their claims.

Applying these particular factors, however, to conditions in the United Kingdom, one finds :-

(I) That traders here have no difficulty in gaining access to the leading officers of a railway company whenever they have any propositions to advance, and that it is a matter of ordinary daily business with the railway officials to study the various conditions of trade, and to consider how far the railway, if only in its own interest, can meet them.

(2) 'That there is no need to set up elaborate machinery to compel the railway companies to do in these directions what they are already willing to do without compulsion.

(3) That, in effect, the greater elasticity of the company system secures to traders many more concessions, which, also, are granted and rendered operative in far less time, than is possible under a rigid system of State operation. 
RAILWAYS AND Nationalisation.

THE ANALOGY OF THE POST OFFICE.

The proposer of a resolution in favour of railway nationalisation, discussed at a meeting of the West Yorkshire Federated Chamber of Trade, held at Keighley in November, I907, said : "When they thought of the excellence of the State postal service . . he could not see why on earth the railways should not be equally well managed."

Between the Post Office and the railways no real comparison can be made. The Post Office was built up by the State on virgin soil, and, except in the case of the telegraphs, the organisation of it involved no capital expenditure in the buying up of vested interests. Even including purchase of the telegraphs there have been no such financial complications as would arise now if the State began to devise a scheme for acquiring the railways and all they represent. Then the principles of a postal service, based on a unified system for the whole country, are altogether different from those of a railway service, with its necessary regard for local conditions, its unavoidable variations in rates, and the competition it meets with from sea, river, and canal. The one service is comparatively simple, and is mainly a matter of good organisation; in the other there are endless complexities and technical details, only to be dealt with effectively by men 
who are railway experts, and have spent their life at the work.

Is it certain, too, that the Post Office has been so brilliant an example of successful management as many people represent? It does, indeed, yield a return of $£ 3,750,000$ a year. But no institution so sure of universal patronage, and enjoying so absolute a monopoly as the Post Office, could very well have been a complete failure; while, on looking into details, we find that concessions and public advantages have ever been extorted from the Post Office rather than spontaneously conceded by State officials, whose natural tendency it is to resent innovations, to get alarmed at the risk and trouble of new departures, and to act generally on the principle of working in accord with old lines and established precedents. The trouble that Rowland Hill went through before he could dispel the fears of the Post Office in regard to penny postage is a matter of history; and the trouble that the present persecutor-in - chief of the Postmaster-General, Mr. Henniker Heaton, gives himself to secure further concessions from a department difficult to move, is a matter of common knowledge. Is it not a reflection on State management that the greatest advances made by the Post Office have been due to the persistency of outside and far-seeing reformers

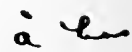
en rather than to the postal officials themselves?

It may be that the Post Office is not solely to 
blame for these tendencies. Behind the Postmaster-General there is the Chancellor of the Exchequer; and whenever the question arises of making a concession which might diminish the profits, if only for a time, the Chancellor of the Exchequer may veto the proposal.

The assumption that State enterprises are run solely in the interests of the general community is no more true in the case of the British Post Office than it is in that of the Prussian State railways-unless the making of profits to pour into the State Treasury be regarded as the main object at which a Government should aim.

Nor has the Post Office attained a success in any way complete. Mr. C. F. Parr, chairman of Parr's Bank, has pointed out that-

Its subsidiary departments, its Savings Bank and its Telegraphs, are both run at a heavy loss. Both must have closed their doors long ago had they been private enterprises, though in their case their close connection with the Post Office gives them special facilities for economical working.

Under competition or private effort, we should long ago have rejoiced in those improvements which Mr. Henniker Heaton presses year after year unavailingly on the authorities. And, after all, it is the excellence of the private carrying companies, railways and others, which makes the postal service what it is.

When the telegraph companies were bought out by the State in I869, the Government predicted that there would be a large annual profit- 
just as the nationalisers to-day are prophesying that the purchase of the railways would yield a good return to the State. In fact the return on the telegraphs was to be sufficient to repay the whole of the purchase money within twenty-nine years." What actually occurred has been thus stated by the Spectator (July I I, I908) :-

As a matter of fact, the profits which the companies had been earning disappeared altogether within two years of the transference of their property to the State. Since that date there has year by year been a loss upon the undertaking. If compound interest be allowed on these losses, as is only reasonable, the aggregate loss to the Exchequer in the thirty-eight years of State ownership will be found to be well in excess of $£ 30,000,000$, and the present annual loss to exceed $£$ I, 000,000.

The Postmaster-General himself said in his annual statement on July 16, I908:--

The principal, in fact the only profitable head of revenue we have now left in the postal system is the penny stamp. That is really the sheet-anchor of our postal revenue. . . . I I do not think I need dwell on the disastrous history of our telegraph system. It was over-capitalised to start with; then came the reduction to sixpenny telegrams, and now it is carried on at a very great annual loss to the Exchequer.

Yet it is, indeed, with the Telegraph Department rather than with the Post Office as a whole that the comparison for present purposes should be made, because in the former case there was an actual "purchase" of established interests, as 
there would be with the railways but as there was not in the collection and delivery of letters. In acquiring the railways, also, the Government would have the question of over-capitalisation " to start with," and that of reductions of rates -with increased expenses-to follow. Would the "very great annual loss" again be very far behind?

Whatever the real success of the Post Office, one could not say that equally good results-so far as the public are concerned-might not have been obtained if the various services rendered had been left open to competition, instead of becoming a State monopoly. Nor has the success attained been such as to warrant in itself the undertaking by the State of a far greater and far more complicated business proposition, in the form of the purchase and operation of the railways.

THE WAR OFFICE.

No resolutions, so far as I am aware, have yet been passed representing the War Office as a paragon of efficient State management, and as affording proof of the capacity of the State to take charge of the railways as well. On the contrary, Commercial Intelligence, in its issue of February 26, I908, claimed to remember that " at the time of the South African War it was freely urged that any of our great railway administrators could have managed the campaign infi- 
nitely better than the War Office, and the Government itself showed its opinion of the capacity of the railway world by appointing a railway man as a commissioner to inquire into the management of the war. Now," the journal continues, "we are asked to substitute for the railway official, as we know him, the Government official."

Is it not a fact, also, that when, in March, 1905, a succession to the Earl of Selborne as First Lord of the Admiralty, was wanted, the choice fell upon the Earl of Cawdor, whose appointment was especially approved because of the experience he had gained and the capacity he had shown as chairman of the Great Western Railway Company? 
204 RaIlways and Nationalisation.

CHAPTER $\mathrm{X}$.

\section{TRADERS AND THEIR GRIEVANCES.}

When one comes to look into the reasons advanced in support of railway nationalisationthat is to say, leaving out of account the question of party policy in its advocacy as a set-off to the movement for tariff reform-one finds that the chief grievances alleged by traders against the railway companies fall under the head of (I) unduly high rates and (2) undue preference to foreign produce; while it is argued that there is little hope of the railway companies themselves affording relief in respect to either of these conditions, the conclusion thus arrived at being that the only real remedy could be secured if the State should take over the whole of the railways, and, by operating them as a single system, effect such economies that there would be ample funds available alike for reductions in. rates and for an improvement in the position of the railway servants. Other allegations and theories are advanced in addition; but the main issue may, I think, be regarded as fairly described in the brief statement of the case just given.

With regard to the rates charged by British 
railway companies it is, in the first place, essential to a full and fair understanding of the question at issue to consider the particular conditions under which the railways were constructed, inasmuch as, in the absence of State aid in any shape or form, a railway company, when recouping itself for the expenditure it has incurred, is necessarily dependent on the fares, rates and charges imposed on those by whom the lines are used.

\section{" A STORY OF SCANDAlOUS FILlage."}

The real position was put very fairly by Mr. Lloyd-George in the course of the debate on the resolution proposed in the House of Commons, on February I I, 1908, by Mr. G. A. Hardy, in favour of State purchase of the railways. Mr. Lloyd-George said :-

He agreed with the Hon. Member for Paddington that there was a good deal of "water" in the capital, but not sufficient appreciably to affect the argument. He would remind his hon. friend that the real difficulty was not so much water as the land. If his hon. friend wanted to see the reason why railway rates were so much cheaper on the Continent than here, he must not place the responsibility altogether upon the railway directors and inanagers, nor even upon stockbrokers, because the House of Commons was largely responsible - he was not sure that it was not entirely responsible. Before they were allowed to get any privileges for the development of their lines, railway companies 
had to go to a gigantic expense and spend huge sums upon experts and others before they could get a Bill through Parliament. Having, perhaps, after a third try, got their Bill through, they were allowed to go down into the country to buy a piece of land. What happened? The persons whose property was developed and whose property was enhanced in value by the transaction got ten times as much value out of it as the railway companies. It was a story of scandalous pillage from beginning to end. The extravagant costs of the land and the heavy expenses were sometimes increased by ludicrous conditions. The London and NorthWestern expresses had to slow down in passing a certain village to three miles an hour simply because that condition had been inserted by some landowner. These circumstances and conditions had so hampered our railways that it was no wonder they could not compete with the railways of Germany and other countries. The matter was a purely business proposition, a proposition for the nation to go into, and to mix it up with questions of prejudice against railway directors was, in his opinion, a mistake. It was quite unnecessary, and created bitterness in the examination of a problem which was a business one.

EARLY DAYS OF BRITISH RAILIVAYS.

To illustrate the conditions under which the earlier railways in the United Kingdom were actually constructed, I cannot do better than give some extracts from a work on "Our Iron Roads," written by Mr. F. S. Williams; and published in $185^{2}$, when the facts he states were still fresh in the public mind. After describing 
the initial steps taken in the promotion of a scheme for a new railway, he proceeds :-

While the arguments and evidence have thus been advanced within the Committee rooms, great efforts have been made "out of doors" by the friends of the Bill. Witnesses have been collected wherever they could be useful, and without regard to expense. If possible, the landowners whose estates the line will traverse have been induced to concur in the scheme, and to signify their assent and consent thereto before the honourable and select Committee. Merchants, manufacturers, and tradesmen have been brought from the towns through which it is intended that the line should pass, to express their opinon in its favour. Objectors to the railroad are conciliated, to effect which all practicable means are rendered available, if they are men of note or influence. The system of "buying off " opposition has, indeed, been carried on to a prodigious extent. When landowners have been asked by the Company whether they approved or not the general design of the proposed railway, they have frequently answered in the negative, although they have openly avowed their anxiety that the railway should be formed, as it would not only be a matter of great personal convenience to them, but that they hoped to gain a "good picking" from it; and they have admitted that their sole object in thus opposing the line was to obtain from the Company a larger sum of money for their land. Of the style in which opposition was carried on in the Committee rooms, some illustrations may be given :-

Often a proprietor, who owned perhaps half an acre, was brought forward by those who were interested in opposing the measure, and counsel, agents, and witnesses were supplied him, without regard to expense, till every means had been exhausted of 
thus producing, through him, an adverse feeling in regard to the project. Some one else was then advanced for the same purpose; and though it was known to every one in the Committee room that these were only the agents of a rival line or interest, yet on the same day the same questions were raised, the same arguments enforced, the same sort of evidence given, to show that all railways were injurious, in perhaps twenty different rooms.

One noble lord had an estate near a proposed line of railway, and on this estate was a beautiful mansion. Naturally averse to the desecration of his home and its neighbourhood, he gave his most uncompromising opposition to the Bill, and found, in the Committees of both Houses, sympathising listeners. Little did it aid the projectors that they urged that the line did not pass within six miles of that princely domain; that the high road was much closer to his dwelling; and that, as the spot nearest the house would be passed by means of a tunnel, no unsightliness would arise. But, no; no worldly consideration affected the decision of the proprietor; and, arguments failing, it was found that an appeal must be made to other means. His opposition was ultimately bought off for twentyeight thousand pounds, to be paid when the railway reached his neighbourhood. Time wore on, funds became scarce, and the Company found that it would be best to stop short at a particular portion of their line, long before they reached the estate of the noble lord who had so violently opposed their Bill, and whose aid they felt themselves sure of obtaining for their second Bill, by which they sought to be released from the obligation of constructing the line which had been so obnoxious to him. What was their surprise at finding this very man their chief opponent, and then fresh means had to be adopted of silencing his objections !

Other instances may be given. A line had to be 
brought near to the property of a certain member of Parliament. It threatened no injury to the estate, either by affecting its appearance or its intrinsic worth; and, on the other hand, it afforded him a cheap, convenient, and expeditious means of communication with the metropolis. But the proprietor, being a legislator, had power at headquarters, and by his influence he nearly turned the line of railway aside; and this deviation would have cost the projectors the sum of sixty thousand pounds. Now it so happened that the house of this honourable member, who had thus insisted on such costly deference to his peculiar feelings respecting his property, was afflicted with the dry rot, and threatened every hour to fall upon the head of its owner. To pull down and rebuild it would require the sum of thirty thousand pounds. The idea of a compromise, beneficial to both parties, suggested itself. If the railway company rebuilt the house, or paid $£ 3^{\circ}$,ooo to the owner of the estate, and were allowed to pursue their original line, it was clear that they would be $£ 3^{\circ}$,ooo the richer, as the enforced deviation would cost E.6o, ooo; and, on the other hand, the owner of the estate would obtain a secure house, or receive $£ 30,000$ in money. The proposed bargain was struck, and $£ 3^{\circ}$,ooo was paid by the Company. "How can you live in that house," said some friend to him afterwards, "with the railroad coming so near?" "Had it not done so," was the reply, "I could not have lived in it at all."

One rather original character sold some land to the London and Birmingham Company, and was loud and long in his outcries for compensation, expatiating on the damages which the formation of the line would inevitably bring to his property. His complaints were only stopped by the payment of his demands. A few months afterwards a little additional land was required from the same individual, 
when he actually demanded a much larger price for the new land then was given him before; and, on surprise being expressed at the charge for that which he had declared would inevitably be greatly deteriorated in value from the proximity of the railway, he coolly replied: " $\mathrm{Oh}$, I made a mistake then, in thinking the railway would injure my property; it has increased its value, and of course you must pay me an increased price for it." Thus it is that in dealing with individuals, men have distinct ideas of justice; while in dealing with the abstraction called a railway proprietary, many seem to think themselves entitled to overreach and to cheat without either restraint or dishonesty.

On one occasion, a trial occurred in which an eminent land-valuer was put into the vitness-box to swell the amount of damages, and he proceeded to expatiate on the injury committed by railroads in general, and especially by the one in question, in cutting up the properties they invaded. When he had finished the delivery of this weighty piece of evidence, the counsel for the company put a newspaper into his hand, and asked him whether he had not inserted a certain advertisement therein. That fact was undeniable, and on being read aloud, it proved to be a declaration by the land-valuer himself, that the approach of the railway which he had come there to oppose, would prove exceedingly beneficial to some property in its immediate vicinity, then on sale.

An illustration of the difference between the exorbitant demands made by parties for compensation, and the real value of the property, may be mentioned. The first claim made by the Directors of the Glasgow Lunatic Asylum on the Edinburgh and Glasgow Railway is stated to have been no less than $\$ 44$,ooo. Before the trial came on this sum was reduced to $\mathcal{E}_{\mathrm{I}} \mathrm{o}, 0 \mathrm{oo}$; the amount awarded by the jury was $\mathcal{E}^{873}$. The opposition thus made, 
whether feigned or real, it was always advisable to remove, and the money paid for this purpose, though ostensibly in the purchase of the ground, has been on many occasions immense. Sums of $£ 35,000$, $E_{40}, 000, E_{50}, 000, E_{100}, 000$, and $£_{120}, 000$ have thus been paid; while various ingenious plans have been adopted of removing the opposition of influential men. An honourable member is said to have received $£ 30,000$ to withdraw his opposition to a Bill before the House; and " not far off the celebrated year 1845, a lady of title, so gossips talk, asked a certain nobleman to support a certain Bill, stating that, if he did, she had the authority of the secretary of a great company to inform him that fifty shares in a certain railway, then at a considerable premium, would be at his disposal. This, of course, is no bribery; but we wonder whether it explains the reason of some people having so many friends in Parliament." Exceptions there have been-we hope there have been many-to this spirit of self-aggrandisement. It was of such that Sir Robert Peel spoke, when, on turning the first sod of the Trent Valley line, he said to its Directors : "I assure them there are many persons in this neighbourhood who have not scrupled to sacrifice private feeling and comfort, by consenting to their land being appropriated to the Trent Valley Railway. They have given that consent from a conviction that this undertaking was one conducive to the public benefit, and that considerations of private interest should not obstruct the great one of the public good. But they have given their consent also in the confidence that this is not one of the ephemeral schemes proposed for mere gambling speculations, or from mere cupidity oi gain. They have given their consent in the confidence a.s $l$ belief that the Directors of tris railroad are men influenced by the honourable ambition of conferring a public benefit on the district with which they are imme- 
diately connected, and that they look for reward, not so much to immediate pecuniary gain, as to the grateful acknowledgments of their fellow citizens for a service rendered to them. On these grounds there has been accorded a willing assent to the passage of the railway through this locality."

One pleasing circumstance, however, highly honourable to the gentleman concerned, must not be omitted. The late Mr. Labouchere had made an agreement with the Eastern Counties Company for a passage through his estate, near Chelmsford. for the price of $£ 35$,ooo; his son and successor, the Right Hon. Henry Labouchere, finding that the property was not deteriorated to the anticipated extent, voluntarily returned $\&_{5}$, 000 .

The cost of purchasing land, and for compensation, has been stated by Mr. Laing, in a paper appended to the evidence given by him before a Select Parliamentary Committee on Railways, as follows :- .

Newcastle and Carlisle Railway ... £2,200 per mile.

Grand Junction $\quad \ldots \quad \ldots \quad \ldots \quad 3,000 \quad$ "

$\begin{array}{llllll}\text { South-Western } & \ldots & \ldots & \ldots & 4,000 \quad,\end{array}$

Manchester and Leeds ... ... 6,150 ",

London and Birmingham and

$\begin{array}{llllll}\text { Great Western } & \ldots & \ldots & \ldots & 6,300 \quad,\end{array}$

while, on three lines, the expenditure has averaged E 14 ,ooo per mile! Mr. Laing estimated that the positive waste of capital which had been incurred in this country, under the head of land and compensation (up to 1850 ), amounted to more than two millions and a half sterling-a sum which has been immensely augmented since that return was made.

The expenditure incurred in procuring legislative authority to construct railways has been, in many cases, scarcely credible. While the Parliamentary, surveying, and engineering costs of the Kendal and Windermere Company amounted to little more than 
2 per cent. on the total outlay of the railway, we are assured that the Parliamentary costs of the-

Brighton Railway averaged

Manchester and Birmingham

Blackwall
... $£ 4,806$ per mile.

$$
\text { ... 5,190 , }
$$

... 14,414 ,

The Brighton line had to contend with three or four other companies during two successive sessions, and when the Bill was before the Committee, the expense of counsel and witnesses was stated at $£ \mathrm{r}$, ooo daily, extending over fifty days. The London and Birmingham line escaped much of this cost by coming earlier into the field; but the Parliamentary and surveyors' expenses even then amounted to $£ 72,000$, which must be regarded as a reproach on the system of legislation which thus permits impediments to be thrown in the way of works of great and acknowledged usefulness. It is also affirmed that " the solicitor's bill of South-Eastern Railway contained ro,00o folios, occupied twelve months in taxation before the Master, and amounted to f240,000. One company had to fight so hard for their Bill that they found, when at length they reached the last stage - that of receiving the Royal Assent-that their preliminary undertakings had cost nearly half a million of money-a sum which had been expended in merely acquiring the privilege of making a railway, and the interest of which has now to be paid by the passengers and goods that travel thereon. Without opposition, the same bill would tave been passed into an Act at a cost not worth mentioning, in comparison with the real expenditure.

The waste of capital, directly and indirectly, in the formation of railways was (in 1852) estimated at not less than $£, 12,000,000$, apart from the loss which has been incurred in the support of unsuccessful bills and the maintenance of unsuccessful opposition. This sum would have been sufficient 
to construct a railway 600 miles long, at the rate of $£ 20,000$ a mile; while the interest which has to be paid by the public in the increased cost of existing lines, amounts, at 5 per cent., to $£ 600,000$. Of the costs of the projects which were ultimately unsuccessful, a single illustration may be given. In the celebrated battle of the Stone and Rugby Railway, the inquiry continued during sixty-six sitting-days, from February to August, I839, and, having been renewed in the following year, the Bill was finally defeated at an expense to its promoters of $E_{14} 46$,ooo.

The total expense per mile of some of the English railways was as follows :-

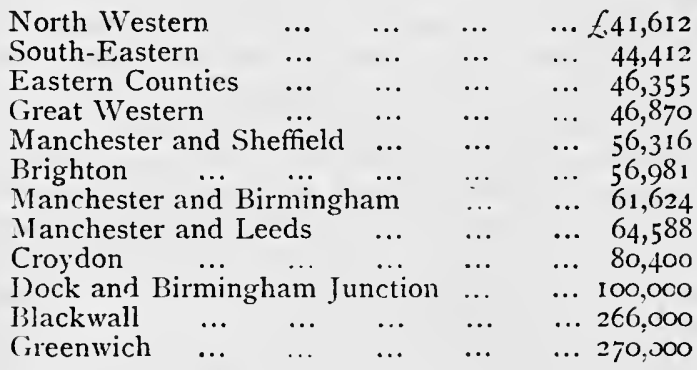

Omitting the three lines last mentioned, which it would not be right to include in computing the arerage, the expense of the remainder is about $£ 5^{6,9} 5$ per mile.

In addition, however, to the cost of the land and the heavy Parliamentary expenses, one must remember that Great. Britain. was the pioneer of railways, and had to pay for costly experiments of which countries starting later in the work of railway construction were able to take full advantage. 


\section{STATE RAILWAY PROMOTION.}

To a certain extent the traders of to-day are necessarily paying for the greed and extortion of a past generation. Yet no scruple is shown by the railway critics in comparing rates and charges in force on lines built under these adverse conditions with such lines as those in Germany, where, as I shall explain in Chapter XI., the promotion of a new railway by a State department is, as regards procedure, little more than a matter of office routine, with an appeal to arbitration should any difficulty arise as to the price to be paid for the land required.

The nationalisers may adduce these conditions as a strong argument in favour of State railways. It certainly would be if the question of the moment were one of providing railways for a country which had either none at all, or not sufficient. In our own case, however, the extortion has already been practised and the mischief done. With comparatively few exceptions, we have now practically all the lines of railway that we require; and the question to be considered is, not the State construction, de novo, of a net-work of railways for the country under a new and economical system, but the State purchase of existing railways, constructed under an old and, as regards the expenditure involved, extremely disadvantageous system. It is no longer a matter of studying ideals. It is a matter of accepting 
the logic of established facts and dealing witt, them as best we can.

COST OF CONSTRUCTION : COMPARATIVE TABLES.

How the cost of construction of railways in the United Kingdom compares with that of railways in other countries throughout the globe is shown by a table published in the "Bulletin of the International Railway Congress Association " for September, 1907. One gathers therefrom that British railways have been by far the most costly to construct of any in the world; but I think it only fair to say that the table must be accepted with a certain reservation, and one that makes the position not quite so bad as the figures would suggest. The table gives " construction capital per mile." But this means route miles, and not track miles; and, as I have shown in introducing the tables given in Chapter III., the railways of the United Kingdom include a good deal of mileage with two, three, four, five or more tracks, whereas a large proportion of colonial and foreign (especially American) railway mileage is single track only. Even, however, allowing for this material consideration, I am disposed to think that the British railways may still be regarded as having been " the most costly to construct of any in the world." The table is as follows :- 


\begin{tabular}{|c|c|c|c|c|}
\hline \multirow{2}{*}{$\begin{array}{l}\text { CoUNTRIFS AND RAILWAY } \\
\text { SYSTEMS. }\end{array}$} & YEAR & MiLEAGE & \multicolumn{2}{|c|}{ Construction Capital. } \\
\hline & \multicolumn{2}{|c|}{$\begin{array}{l}\text { To which the data as to } \\
\text { the cost apply. }\end{array}$} & Total. & $\begin{array}{c}\text { Per } \\
\text { mile. }\end{array}$ \\
\hline EUROPE. & & Miles. & 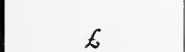 & 6 \\
\hline $\begin{array}{l}\text { Great Britain and Ireland: } \\
\text { The entire system } \\
\text { Germany : }\end{array}$ & 1903 & $22,430 \cdot 6$ & $1,245.050,000$ & 55,506 \\
\hline $\begin{array}{l}\text { The entire system } \\
\text { Austria-Hungary ; } \\
\text { Austria, the entire }\end{array}$ & 1905 & $34,124 \cdot 5$ & $718,950,000$ & 21,322 \\
\hline $\begin{array}{l}\text { system } \\
\text { Hungary, the entire }\end{array}$ & 1905 & $13,00^{\circ} 3$ & $295,300,000$ & 22,628 \\
\hline \begin{tabular}{llrr} 
& & \multicolumn{2}{r}{ system } \\
France & $\ldots$ & $\ldots$ & $\ldots$
\end{tabular} & $\begin{array}{c}\text { Dec. 3I, I905 } \\
1903\end{array}$ & $\begin{array}{l}\text { II } 1,297 \cdot 3 \\
28,091 \cdot 6\end{array}$ & $\begin{array}{l}150,450,000 \\
716,350,000\end{array}$ & $\begin{array}{l}13.360 \\
25,497\end{array}$ \\
\hline $\begin{array}{l}\text { Belgium : } \\
\text { Belgian State } \ldots \\
\text { Netherlands : }\end{array}$ & 1904 & 2,4837 & $\S_{5,950,000}$ & 34,602 \\
\hline $\begin{array}{l}\text { The entire system } \\
\text { Denmark: }\end{array}$ & 1897 & $1,653^{\circ} 5$ & $28,700,000$ & $17,35^{\circ}$ \\
\hline $\begin{array}{l}\text { State railways ... } \\
\text { Norway : }\end{array}$ & I905-1906 & $\mathrm{I}, \mathrm{I} 64^{\circ} 5$ & $11,550,000$ & 9,925 \\
\hline $\begin{array}{l}\text { The entire system } \quad \ldots \\
\text { Sweden : }\end{array}$ & $1905-1506$ & $1,396^{\circ} 2$ & $11,950,000$ & $8,54^{8}$ \\
\hline $\begin{array}{l}\text { State railways } \\
\text { Private Conpanies } \\
\text { Russia (without Finland) }\end{array}$ & $\begin{array}{l}1905 \\
1903\end{array}$ & $\begin{array}{l}2,609 \cdot 2 \\
5,060^{\circ} 5\end{array}$ & $\begin{array}{l}25,100,000 \\
24,300,000\end{array}$ & $\begin{array}{l}9,6 \mathrm{I} 7 \\
4,8 \mathrm{OI}\end{array}$ \\
\hline $\begin{array}{l}\text { The entire system } \\
\text { Finland, State railways }\end{array}$ & $\begin{array}{l}1903 \\
1905\end{array}$ & $\begin{array}{r}36,683 \cdot 9 \\
1,892 \cdot 7\end{array}$ & $\begin{array}{r}612,100,000 \\
13,200,000\end{array}$ & $\begin{array}{r}16,685 \\
6,978\end{array}$ \\
\hline $\begin{array}{l}\text { Roumania: } \\
\text { The entire system }\end{array}$ & & & & \\
\hline $\begin{array}{l}\text { The entire system } \\
\text { Servia : }\end{array}$ & $1904-1905$ & $\mathrm{I}, 975^{\circ} 4$ & $35,450,000$ & 17,953 \\
\hline $\begin{array}{l}\text { State railways ... } \\
\text { Bulgaria : }\end{array}$ & 1904 & $336 \cdot 2$ & $4,250,000$ & 12,712 \\
\hline $\begin{array}{l}\text { State railways ... } \\
\text { Italy : }\end{array}$ & 1904 & $75^{1 \cdot 2}$ & $6,200,000$ & 8,567 \\
\hline $\begin{array}{l}\text { The entire system } \\
\text { Switzerland : }\end{array}$ & 1903 & $10,022 \cdot 3$ & $228,800,000$ & 21,041 \\
\hline $\begin{array}{l}\text { The entire system } \\
\text { Spain : }\end{array}$ & 1904 & $2,603^{*} 6$ & $55,750,000$ & 21,807 \\
\hline Northern railway & 1903 & $2,271 \cdot 8$ & $46,200,000$ & 20,345 \\
\hline $\left.\begin{array}{ccc}\text { Total and } & \text { average } & \text { for } \\
\text { Europe } & \ldots & \ldots\end{array}\right\}$ & & $179,902^{\circ} \circ$ & $4,315,600,000$ & 23,979 \\
\hline
\end{tabular}




\section{I8 Rail.ways and Nationalisation.}

\begin{tabular}{|c|c|c|c|c|}
\hline \multirow{2}{*}{$\begin{array}{l}\text { Countries and Railway } \\
\text { Systems. }\end{array}$} & \multirow{2}{*}{\multicolumn{2}{|c|}{\begin{tabular}{c|c} 
YEAR & Mileage \\
To which the data as to \\
the cost apply.
\end{tabular}}} & \multicolumn{2}{|c|}{ Construction Capital. } \\
\hline & & & Total. & $\begin{array}{l}\text { Per } \\
\text { mile. }\end{array}$ \\
\hline $\begin{array}{l}\text { OTHER PARTS OF THE } \\
\text { GLOBE. }\end{array}$ & & Miles. & $\mathcal{L}$ & $\mathcal{L}$ \\
\hline United States of America & June 30, I 904 & $213,862 \cdot 4$ & $2,774,750,000$ & I 3,498 \\
\hline Canada $\quad . \quad \ldots \quad \ldots$ & June 30,1905 & $20,597^{\circ}$ & 262,20 & I $2,7,31$ \\
\hline Cuba $\quad \ldots$ & 1905 & $\mathrm{I}, 533^{\circ} 6$ & $13,650,000$ & 8,932 \\
\hline Uruguay $\ldots . \quad \ldots$ & I898-I899 & $997^{\circ} 3$ & I I , 050,000 & I 1,089 \\
\hline Chili : State railways & Dec. $3 \mathrm{I}, \mathrm{I} 898$ & $\mathbf{I}, 375^{\circ} \mathbf{I}$ & I $5,800,000$ & I 1,302 \\
\hline Argentine Republic & 1904 & $12, \mathrm{C}$ & I I $7,700,0$ & 9,753 \\
\hline British India $\quad \ldots$ & Dec. 3I, I905 & $28,289 \cdot 7$ & 243,70 & 8,6 I 5 \\
\hline Japan $\quad \cdots$ & Mar. 3I, I905 & $4,693 \cdot 3$ & $41,300,000$ & 8,795 \\
\hline Siam & $1905-1906$ & $3 \cdot 5$ & 1,45 & $5,54^{8}$ \\
\hline Java $\quad \ldots \quad \ldots$ & 1893 & $7 \cdot 1$ & $0, \infty 00$ & 10,921 \\
\hline Algiers and Tunis & Dec. 3I, I9O2 & $2,269^{\circ} 9$ & $27,300,000$ & I 1,863 \\
\hline Cape Colony $\quad$... & Dec. 3I, 1905 & $2,986^{\circ} 4$ & $30,550,000$ & 10,237 \\
\hline Natal $\quad \ldots$ & Dec. $3 \mathrm{I}$, I9O5 & $817 \cdot 7$ & I 3,20 & 17,177 \\
\hline ierra-Leone & 1903 & $221 \cdot 8$ & 1,0 & 4,313 \\
\hline Gold Coast & 190 & 2 & 1,80 & 10,300 \\
\hline Lagos $\quad \ldots \quad \ldots \quad \ldots$ & 1903 & 1249 & 900,000 & 7,081 \\
\hline Colony of New Zealand... & Mar. 31, I905 & 2,3 & 22, I 50,000 & 9,325 \\
\hline $\begin{array}{lll}, & \text { of Victoria } & \ldots \\
,, & \text { of New South }\end{array}$ & June 30, I905 & $3,3 \mathrm{So} \cdot 3$ & $42,00,000$ & $12,45^{6}$ \\
\hline Wales & Iune 30,1905 & 3.28 & $43,900,0$ & I 3,390 \\
\hline of South Australia & June 30 , I905 & $\mathbf{I}, 74$ & I $3,850,000$ & 7,940 \\
\hline of Queensland & June 30, I 905 & $3,09 I^{\circ} 4$ & $22,050,000$ & $7, \mathbf{I} 3 \mathbf{I}$ \\
\hline $\begin{array}{l}\text { of Tasmania } \\
\text { of IVestern }\end{array}$ & June 30,1905 & $462 \cdot 3$ & $4,000,000$ & 8,248 \\
\hline Australia & June 30, I 905 & $1,605^{\circ} \mathrm{o}$ & $9,500,000$ & 5,922 \\
\hline $\begin{array}{l}\text { Total and average for } \\
\text { other parts of the globe }\}\end{array}$ & & $306,820 \cdot 6$ & $3,720,100,000$ & 12,150 \\
\hline
\end{tabular}

THE QUESTION OF EXCESSIVE RATES.

In view of all the facts and figures here stated, it is obvious enough that the British railway companies have started heavily handicapped by their cost of construction, and have certainly 
been at a disadvantage as compared with State railways built at a substantially lower sum per mile in other countries, or with the railways of companies which have received more or less generous State aid. Supplementing the heavy cost of construction, there has been the fact that the requirements of Parliament and of the Board of 'Trade, the exactions of local rating aúthorities, and substantial advances in various items of expenditure have borne heavily on the working expenses. In the circumstances it should not be surprising if British railway rates did not always compare favourably with those charged elsewhere.

But are the rates charged always so high, and do they always compare so unfavourably with the rates charged on Continental lines (built and operated uncler conditions entirely different) as the nationalisers assert? Abundant figures are advanced by them and by dissatisfied traders in general from time to time, and the public are apt to assume that on such figures implicit reliance can be placed. My own experience, however, in submitting them to the test of inquiry, is that, while legitimate grievances certainly may exist, figures of the type in question are often either inaccurate in themselves or are used without reference to some condition or service, included or omitted, as the case may be, which would show the real position to be very different from what is alleged to be the case. 


\section{FIGURES AND FALLACIES.}

As typical of the arguments used I might refer to the following table of comparative rates given in a pamphlet (published 1907) on "The Nationalisation of Irish Railways: Defects of the Present System," by Mr. William Field, M.P., a member of the executive committee of the recently-formed Railway Nationalisation Society :-

For same Distance.

British. German. Belgian. Dutch.

Hardware :

Birmingham to London ... Cotton Goods :

Manchester to London ... General Machinery :

Leeds to Hull Wool :

Liverpool to Manchester... Cattle :

Hull to Manchester

...

$23 / 6$

I I $/ 4$

I 3/I I

I $1 / 3$

$36 /-$

$$
20 /- \text { to } 23 /-\quad 18 / 1
$$

$14 / 4$

25/-

$4 / 6$

8/-

$5 / 6$

$9 / 2$

$4 / 2$

4/I I

$4 / 2$

$59 / 3$

$3^{8 / 6}$

$29 / 6$

$37 / 6$

Mr. Field admits that he quotes these figures from Fabian Tract No. 98, "State Railways for Ireland," published in October, I899, and the writer of the Fabian tract in question admits, in turn, that he took them from what he calls a " masterly" report presented by Sir Bernhard Samuelson to the Associated Chambers of Commerce in I886; but neither the writer of the tract nor Mr. Field himself seems to have gone to the slightest trouble to investigate the trustworthiness of these now 20-year-old figures. Each 
repeats them, and various other writers have done the same, as though they were absolutely reliable. Yet the fallacies on which Sir Bernhard Samuelson's report was mainly based were thoroughly exposed in 1886 , the same year in which it was issued, by the late Mr. J. Grierson, general manager of the Great Western Railway, in the appendix of his book on "Railway Rates, English and Foreign."

Mr. Grierson said of the report which, Mr. Field serves up afresh two decades after date :-

Sir B. Samuelson's report contains many errors of detail. Comparisons throughout have been made without due regard to the conditions attaching to the rates, or to the different circumstances under which the traffic is carried. . . Many of the deductions are inaccurate and misleading.

These errors make many, of the comparisons valueless. . . . Sir B. Samuelson has in numerous cases assumed British rates, which include either collection or delivery, and in some cases both of those services, to be station-to-station rates, and compared them as such with station-to-station rates on the foreign lines. . . . In no single instance has Sir B. Samuelson taken in his comparisons the lower owner's risk chargeable at the option of the consignor. . . . In almost every instance Sir B. Samuelson has taken the lowest rates in Germany, Belgium, and Holland, which are applicable only to full truck loads of 5 and ro tons, and in some cases, viz., Belgium, to a minimum weight of $8 \mathrm{cwt}$. These he has used for the purposes of comparison with English rates for any quantities over 500 lbs. . . In some instances Sir B. Samuleson has not included in the foreign rates the charge for loading and unloading. .... Such 
are some examples of the errors vitiating the conparison.

And such, it may here be added, is the authority whom Mr. Field now brings forward, over 20 years after this exposure, in support of his own attack on the railway companies. Incidentally I might mention that this same report by Sir Bernhard Samuelson is one of the authorities chiefly relied on by Mr. Clement Edwards, M.P., chairman of the executive of the Railway Nationalisation Society, in his book on "Railway Nationalisation" (1898).

FIGL'RES AND FACTS.

As for the specific comparisons given by $\mathrm{Mr}$. Field, I find, as the result of my own inquiries, that the reply thereto is as follows:-

HARdware. - The British rate, Birmingham to London, applies to any consignment weighing over 300 lbs. and includes both collection from the senders and delivery alongside ship. The foreign rates are based on special tariffs applying to full truck loads of not less than five tons, and do not include either collection or delivery.

Cotton Goons.- The Manchester to London rate is given as $36 \mathrm{~s}$., but an export rate of $25 \mathrm{~s}$. a ton has long been in operation, and under it many thousands of tons of cotton goods have been conveyed from Lancashire to London for 
export. This 25s. rate also includes collection from consignor and delivery alongside ship, the cost of which services would have to be added to the German, Belgian and Dutch rates.

General Machinery.-The Leeds to Hull rate should be given as I 2s. $6 \mathrm{~d}$., not $25 \mathrm{~s}$. - It includes the same services as in the previous cases.

Wool.-No wool is carried between Liverpool and Manchester. The rate quoted is a "paper" rate, and is not used. There being no traffic, a special rate has not been arranged.

Cattle.-The figures given under this head are especially characteristic and misleading. There is nothing to show whether they are rates for truck-loads of cattle or quotations of rates per head of cattle. Presumably they are the former. In any case they further ignore the fact that the charges for cattle vary arcording to the size of the truck and the number of beasts accommodated therein. The rates for cattle from Hull to Manchester from October, 1872, to December, 1892 (covering the period dealt with in the Samuelson-Field figures), and the corresponding rates since that date, are as follows:-

Size of Truck. Average Loading. Rates from 1872 I'resent to 1892 . Rates.

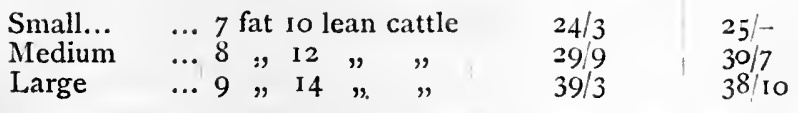


It will thus be seen that the quotation in respect to the British rate, 59s. 3d., reproduced by $\mathrm{Mr}$. Field, is 2os. in excess of even the highest actual rate for the period in question, while no mention whatever is made of the existence of other rates which are less than the foreign rates given. Further, the foreign rates may be in respect to a considerable movement of cattle, and this is certainly the case in Holland, where large numbers of beasts are brought down to the coast, and slaughtered there for the Dutch dead meat trade with England. Between Hull and Manchester, however, cattle do not pass in any appreciable number, and one line operating between those places has gone for twelve months without carrying any cattle at all from either of these points to the other.

Mr. Grierson concluded his comments on Sir B. Samuelson's report thus :-

It is, of course, difficult for any person, even when practically acquainted with railway business, to appreciate the practical effect of the different conditions under which traffic is carried on foreign and English railways. It is not surprising that Sir B. Samuelson has evidently not become fully acquainted with all the conditions of carriage, or that he has omitted to give them their proper value in the tables he has prepared. Unfortunately, owing to. the omissions, the conclusions which he draws are in some cases erroneous and in others misleading.

That perfectly fair criticism still applies to many of the comparisons so freely made to-day; 
but it is upon comparisons of this type that the nationalisers largely depend in the presentation of their case.

\section{A QUESTION OF PINEAPPLES.}

For a recent example of the assertions that are accepted with implicit confidence by dissatisfied traders, I would call attention to the following extract from a report, published in the Daily Telegraph of April 20, I9o8, of the proceedings at a meeting of the Canterbury Farmers' Club and East Kent Chamber of Agriculture, when the subject of railway rates was discussed :-

A case was quoted in which an importer brought a cargo of 7,000 cases of pineapples from the Azores. An endeavour was unsuccessfully made to obtain satisfactory rates from Plymouth and Dartmouth to London, and it was then practically decided to unload the ship at Newhaven. Then someone suggested Dieppe. The rates thence were found to be even more favourable. The result was that the ship was sent to Dieppe and unloaded there, the pineapples being transhipped thence across the Channel to Newhaven by the railway company, and conveyed to London at a cheaper rate than they were prepared to accept for them from Newhaven.

I have communicated with each of the railway companies one or other of whom must have been concerned in this not insignificant consignment of 7, ooo cases of pineapples, if the question of its transport by rail had arisen at all. The replies I have received show that in each instance 
an inquiry had been made by the company, but that nothing whatever was known of the matter by their officers. "So far as we could find," wrote one chief goods manager, "the statement appeared to be an absolute invention-a pure fabrication."

\section{MISLEADING THE COMMONS.}

Then, in the course of the debate on Mr. Hardy's nationalisation resolution in the House of Commons, Mr. Chiozza Money said, "It seemed to him as true now as it was when it was stated by a Parliamentary Committee in 1872 that the case of the public against the monopolist charges of the railway companies was a very strong one." But on referring to the report of the Parliamentary Committee of 1872 I find that the statement in question has a bearing quite different from that which $\mathrm{Mr}$. Money represents. It occurs in the section headed, "Publication of Rates," where the Committee show how "the rates in the case of all the great companies are numbered by millions," and proceed :-

On the other hand, the case of the public against the railway companies is a very strong one. They are monopolists who are unlimited in their charges for carriage. . . . It is to their interest . . . to give the public all possible information about their charges. . . . Under these circumstances the Committec are of opinion that . . . every company should be compelled to keep at every station a book of all the rates, etc. 
These references to an entirely different matter, and one in regard to which the recommendations made have since been carried out, were thus distorted by Mr. Money into a complete misrepresentation of the facts, made in the House of Commons itself, and accepted, probably, by the majority of those who either heard or have read them as a perfectly accurate statement.

Numerous investigations of grievances and allegations of the type here presented, with results akin to those mentioned, have led me to the conviction that, while some of them may be perfectly genuine, in no instance is it safe to accept complaints as to specific rates or charges on British railways until one has investigated the matter, and ascertained the real facts of the case. "Rates," says a circular issued by Mr. Clement Edwards, Mr. Field, and the other members of the Railway Nationalisation Society's committee, " are unreasonably high in themselves." But there is always a suspicion that,. whether in giving actual figures, or in making merely vague assertions such as this, the leaders of the nationalisation party are so anxious to make up a "case" against the railways that they do not always stop to inquire fully whether or not their statements are really warranted. The fact that one "authority" has said something is considered sufficient in itself, and fictions once started are rarely overtaken. 
The whole question of railway rates is full of complexities and anomalies, the result, in part, of conditions geographical, economic, and competitive (in regard especially to sea transport) which could no more be ignored under State operation of the railways than they can be under company operation. But adequate inquiry would show, probably, that Mr. Grierson's criticisms of Sir B. Samuelson's figures apply, in one way or another, to a very large proportion indeed of the comparisons which are made between British and Continental rates; though with regard to these there are still further considerations, with which I shall deal in the next chapter.

\section{PREFERENTIAL RATES.}

The circular of the Railway Nationalisation Society follows up the assertion that " rates are unreasonably high" by alleging that " they are even sometimes disastrous or oppressive to the home trader through the preferential treatment conceded to the foreign producer."

IVe have here another of the main arguments on which the demand for nationalisation is based. Mr. G. A. Hardy, when proposing his resolution in the House of Commons, spoke of "the preferential transport tax exacted by the railway company, which frequently gave to the foreign producer a monopoly here, to the exclusion of our own farmers" ; while the resolution itself 
declared that in "view of the -widespread complaints on the part of traders, agriculturists, and the general public with regard to railway charges and facilities, and particularly with regard to preferential treatment of foreign goods," the time had come to consider how far these evils could be remedied by State purchase of the railways.

The nationalisers conveniently ignore the fact that the subject of preferential treatment was investigated by a Departmental Committee of the Board of Agriculture appointed in 1904 " to inquire into and report whether preferential treatment is given by the railway companies in Great Britain to foreign and colonial, as compared with home, farm, dairy and market garden produce." The report of this Departmental Committee was issued in 1906 , and it stated, among other things :-

In the view of the majority of the Committee, the meaning to be attached to the words, "preferential treatment," in the reference, is that their investigations should be directed to ascertaining whether there is any preference beyond what is sanctioned by the existing law; in other words, whether undue preference is accorded by the railway companies to foreign and colonial as compared with home produce.

Dealing with this view, the Committee find that the evidence has not established the existence of any such undue preference. 
"PREIERENCE" OR " UNDUE PREFERENCE?"

The whole question turns, of course, on the difference between "preference" and "undue preference." The railways give lower rates to a trader who regularly consigns goods alike in large quantities and under such conditions as regards packing, etc., that they can be loaded to the best advantage in the trucks than they do to a trader who sends only small and occasional consignments so packed, or with such absence of packing, that they involve more trouble in handling, take up more space in the wagons, and are, generally, less remunerative to carry. In these circumstances the former trader certainly does get a preference over the latter, and it would be inconsistent with the ordinary principles and practice of commercial life if he did not. It is, in effect, just the same preference that the wholesale man can invariably secure over the retail man.

The real point is whether the railway companies show " undue" preference, by conceding to one trader rates which they refuse to another under the same or similar circumstances and conditions; and of this, the committee declared, there is no evidence. The rates given are open to all traders, irrespective of nationality. If, in effect, foreigners, by reason of their greater volume of production, or because of a better system of marketing, due, in part, to an effective 
system of organisation, can alone take advantage of certain rates, there is no reason why these should be denied to them because British producers are unable, or unwilling, for some reason or other, to fulfil the same conditions. To do so, and to fix the rates for the large consignmentswhich happen to come from abroad-on exactly the same basis as the small consignments would be unjust to the one trader, and, in effect, mean the adoption of a protective policy for the other; while to compel the railway companies to concede exactly the same rates to occasional consignments of ill-packed hundred-weights as they give to regular truck-load lots would not only be inconsistent with the aforesaid conmercial principles, but would rob the companies of the fair profit to which they are entitled.

\section{RAILIVAYS AND PROTECTION.}

Nationalisation of the railways could alter this position on one condition only-the adoption, namely, by the State of a policy of Protection for the home producer, the railways becoming part of the State machinery to be employed for restricting foreign imports and assuring greater chances to the home producer. The State would then, in effect, give an undue preference to the latter over the former, and the railways would operate in accordance with the fiscal policy of the country, as is the case in Germany. The State could certainly do this, if it thought fit; but so 
long as the railways belong to commercial companies they must necessarily be operated on commercial rather than on political lines.

\section{EQUAL MILEAGE RATES.}

Another considerable group of grievances turns upon the theory of equal mileage rates. If, it is argued, the distances from $\mathrm{A}$ to $\mathrm{B}$ and from $\mathrm{C}$ to $\mathrm{D}$ are equal, then the rates charged should also be equal; if it is a greater distance from $C$ to $D$ than it is from $A$ to $B$, then there should be a corresponding difference in the rates; if one trader lives near to a large market, he should not be deprived of his "geographical advantage" (as it is called) by the concession to another trader, at a considerable distance further, of a rate which works out at substantially less per ton per mile, and enables hin to compete on the same market with his more favourably-situated rival. When railway companies disregard such theories as these-and they invariably do-complaints arise, and nationalisation is supported because the equal mileage rate theory is more especially favoured by State railway administrations; though the reasons for this favour can be easily accounted for. The system looks simple : given the rate and the distance, the charge will be so much; and it suits the convenience of a Government which, having to satisfy mutual jealousies and reconcile the interests of one district with those of another, can say, "Well, you 
see, we treat you all alike. These are our regular charges, and we cannot discriminate by giving different terms to different traders."

\section{A SOUTH WALES GRIEVANCE.}

To illustrate the nature of the grievances ventilated from time to time in the United Kingdom in connection with equal mileage rate theories I might offer the following example, taken from a short article on " Nationalisation of Railways," published in the Great Western Railway Magazine for March, I9o8:

Only last month an illuminating case affecting the Great Western Company was before the Court of the Railway and Canal Commissioners. The complaint was that the Swansea fish rate to large consuming centres was not reasonable in view of the same rate being charged from the more distant port of Milford. The Court held that the Swansea rate was reasonable, and that there was no case for raising the other, inasmuch as it was "clearly in the public interest that as many avenues of approach to the markets as possible should be kept open" and that "the rate to the various towns cannot be raised if Milford fish is to compete in the markets with that which comes from other ports." Here was a case in which the Company were doing their best to serve not only a struggling industry, but also to carry cheap food to the public markets, and getting pilloried for their pains !

\section{AN IMPRACTICABLE SYSTEM.}

Various Royal Commissions and Parliamentary Committees have investigated this question 
of equal mileage rates, and have invariably reported upon it as impracticable, for the United Kingdom at least. Among other reasons advanced for this view is that it would shut out the trader in (say) Scotland, Ireland, or Cornwall from competing with traders located much nearer to the London or the Midland markets, and lead to a congestion of producers in the neighbourhood of large centres of population, instead of leaving them to spread out through the country, as it is desirable, in the national interest, that they should do.

\section{A COMPARISON OF RESULTS.}

In the United States the non-equal mileage rates system has been carried so far that goods from any point in the State of California are conveyed to any point east of the Mississippi at the same rate. 'This "blanket system," as it is called, practically ignores differences in distance. It creates endless "anomalies" and "inconsistencies "; but it charges no more than the traffic will bear; it has been of infinite service in developing the resources of California; it has enabled scores of places situated far from either the Atlantic or the Pacific coast to become important centres of distribution; and it has placed the different eastern ports in a position of much greater equality than would otherwise have been possible.

In Australia and in South Africa, where equal 
mileage rates are in vogue, the tendencies have heen for producers to keep as near to the point of consumption or to the port of dispatch as possible, in order to save the considerable difference they would have to pay in the fixed and unyielding railway rates if they carried on their business at any great distance. When the rate from a place 200 miles from a port is about four times the amount of the rate from a point only 50 miles from the port-or any other distance in the same proportion-the trader will naturally remain within the shorter radius if he can, whereas if the difference is not so great as to be prohibitive, he might prefer to go further out, and so, indirectly, assist in a wider distribution of population.

\section{A STORY FROM GERMANY.}

An instructive story, dealing with the question of equal mileage rates in Germany, in combination with considerations of politics, protection, and geographical advantage, is told by $\mathrm{Mr}$. Hugo R. Meyer in the Journal of Political Economy, published by the University of Chicago Press.

Alluding to the results of three investigations by the Statistical Department of Berlin into the sources of the milk supply of that city and its immediate suburbs, Charlottenburg, Schoneberg and Rixdorf, Mr. Meyer said they showed that-

For all practical purposes the railway freight 
charges prohibit the importation of milk from points distant more than 75 miles; that the railway freight charges are so high that it pays to utilize the courts and backyards of Berlin, Charlottenburg, Schoneberg, and Rixdorf for the purposes of stabling milch cows, which supply I 7 per cent. of the milk consumed in those cities; and that the effect of the distance tariff has been to concentrate within a distance of $5^{6}$ miles of Berlin no less than 85 per cent. of the dairy cows whose milk is sent to Berlin by rail.

Mr. Meyer went on to say that in Igoo the "Berliner Milch-Centrale" was founded by the Brandenburg members of the "Bund der Landwirte" (which he describes as "one of the most powerful political organisations in Germany"'), for the purpose of keeping up the price of milk sold in Berlin. The retail dealers organised a counter-movement, and appealed to the railway department for such reductions in freight charges as would make it possible to send milk into Berlin from points distant 187 miles; but, although the request was supported by the leading commercial organisations of Berlin, it was refused by the railway department, such refusal being due, Mr. Meyer alleges, to the unwillingness of the department to precipitate a conflict of interests between the near-by producer and the distant producer. "The fact," he adds, "that the "Bund der landwirte' desired to raise the price of milk by limiting the production for the Berlin market was also a factor that influenced the railway depart- 
ment." A scheme for bringing milk from Denmark to Berlin in tank-cars also had to be abandoned owing to the attitude of the State railways administration, first of all in declaring that milk was not one of the articles enumerated in the tariff governing the shipment of liquids in tankcars, and afterwards in imposing a freight charge on the weight of the tank, both coming and going, so that the business became no longer remunerative. The results have been seen in a serious scarcity of milk in Berlin in the summer and autumn. Mr. Meyer adds :-

The wretched conditions under which Berlin is supplied with milk are in no way due to lack of enterprise on the part of the milk-dealers of Berlin, nor are they in any way due to any lack of technical efficiency on the part of the Prussian State railways. Those wretched conditions are due solely to the fact that, under the making of railway rates by Government in Prussia, it has been found politically necessary to make railway rates very largely on the principle that "the natural disadvantages of the more distant producers" may not be "overcome," lest "the producers nearer the market" be "denied recognition of their more favourable location."

\section{LONDON'S MILK SUPPLY.}

Comparing London conditions with those of Berlin, one finds that here there is no suggestion either of politics influencing railway rates for agricultural products or of disadvantages being placed on the distant as compared with the near 
producer. Nor is there any suggestion of a 75mile radius. Milk comes, for example, in fair quantities to London from St. Erth, Cornwall, a distance of 315 miles; it comes in very large quantities from Egginton Junction, a collecting point in North Staffordshire, distant 154 miles from London; and, also, and more especially, from the district between Swindon, 77 miles from London, and Bristol, i 8 miles. This spreading out of London's milk-supply area is due to the policy of the British railway companies (acting on principles directly opposed to those of the Prussian State railways) in so arranging their rates as to enable producers at a distance from great consuming centres to compete better with those who, from a geographical standpoint, are more favourably situated. Here the ordinary rates per Imperial gallon for the transport of milk by rail are :-Up to 20 miles, $\frac{1}{2} \mathrm{~d}$.; above 20 and up to 40 miles, $\frac{3}{4} \mathrm{~d}$.; above 40 and up to roo miles, Id.; above roo and up to 150 miles, $1 \frac{1}{4} \mathrm{~d}$.; above 150 miles, $1 \frac{1}{2} \mathrm{~d}$. (with a minimum as for 12 imperial gallons per consignment), such charges including carriage of the returned empty cans, though not collection and delivery.

There is no room for doubt as to which of the two systems here described is the better from the point of view of public interests. In the one case we find an undesirable "discrimination" in favour of the near producer; but, although he 
gains, the dwellers in the capital suffer. In the other case the near producer loses his geographical advantage, and meets a much keener competition in the capital, to his financial disadvantage; but British agriculture gains by the widening of the area of production; the community gain by the non-existence of any need for dairy farmers to crowd into the immediate neighbourhood of great towns, and consumers gain by being assured abundant supplies of a necessary of life at reasonable prices.

\section{THE TRADER AND NATIONALISATION.}

Whether the grievances of the British trader against the railway companies are always well founded or not, and admitting that some of them may be, the practical question arises: What are his prospects of any real gain under a system of railway nationalisation?

The trader is told of economies from which he would benefit by getting lower rates. If these economies could, by any possible arrangement, be made by the existing companies, he would have a much greater chance of benefiting from them than when, under nationalisation, a new State department had to be set up, the cost of which would probably go far towards reducing the amount of the possible savings, while his claims for a share in the eventual balance might have to compete with those of the railway men for higher wages, and those of the Chancellor of 
the Exchequer for contributions to the national finance. To say the least of it, therefore, the prospect of the trader securing any material reduction in rates and charges (especially as the lines would still be required to pay their way) is distinctly doubtful.

\section{TRAIN SERVICES.}

Then the anticipated economies are to be effected in part by a reduction in the number of trains run. If this meant any material decrease in the facilities now open to the trader for the transport of his goods, he would have no reason to rejoice over the new conditions. Nor, if the Continental system of State ownership were introduced here, might he approve of the Continental system of railway operation, with its slow and fast goods trains - the latter, equivalent to our ordinary goods services, costing double the "slow goods" rates-and the leeping back of other than "fast goods" consignments for a day or two when necessary in order to allow of better loading. 'This arrangement would certainly permit of economies being made in working expenses, but it would also necessitate a considerable change in the trading conditions of the United Kingdom, especially as regards the keeping of larger stocks on hand by the trader than is usually done under the present system of practically express rail transport. 


\section{WAREHOUSING AND WHARFAGE.}

There are other questions besides. The railway companies have large warehouses in which many traders in leading commercial centres store their goods, otherwise having only a small office from which they send their instructions to the railway company as to the distribution of the consignments. It is doubtful if these railway warehouses pay in themselves, but they are of great advantage to the traders, and they encourage traffic. If the Government took over the railways, would they still afford the same facilities to the traders, or would they say, as the directors of State systems on the Continent say : " Our business is to provide rail transport. The traders must provide their own warehousing "?

The State might effect a saving in this way, but the result would be disastrous to many a trader who now economises in rent, rates, taxes and labour, thanks to the provision made for him by the railway companies-a provision of which he is often able to take advantage without paying anything beyond the railway rate, when this includes a certain period of free storage.

In addition to the warehouse accommodation, a good deal of "wharfage" on the railway sidings is placed at the disposal of traders, either free or at a very low charge. In London the coal merchants pay nothing at all for the space allotted to them for their supplies on land adjoin- 
ing the railway stations. In Berlin the State charges so high a rent for such accommodation that the coal dealers have to set up their depôts some miles out, and cart, at considerable expense, into the city.

\section{CREDIT.}

In England a generous degree of credit is allowed by the railway companies to traders, many of whom thus practically carry on their business (especially if one includes the warehouse accommodation as well) with the railway con:pany's money. The Prussian State railway, on the other hand, gives credit only when the trader deposits in advance securities valued at the full amount of the charges likely to be made against him month by month. If, once more, our railways are to be nationalised on the German model, would the State retain the existing system, or would its business motto be, "Terms: Cash," as on the Prussian State railways and in the British Post Office? This practice would be an economy for the railway, since it would reduce clerical work and avoid the possibility of bad debts. But what would the traders say?

\section{CONSIDERATIONS FOR THE TRADER.}

A revolutionary change in railway ownership in this country might, therefore, involve a like revolutionary change in the general trading con- 
ditions, unless the Government, when seeking to follow Continental methods, should abandon some of the fundamental principles on which the operation of the Continental State railways is based. The traders have, in fact, much more to consider than whether they would be likely to get, in the way of rate reductions, any share in the suggested, though wholly problematical, savings.

They must consider, for instance, what would be their relations with the railways when these are no longer controlled by private companies, but by State officials. Under present circumstances traders wishing for an alteration in rates or some change in existing conditions, can deal direct with a railway officer, who, unless the matter is one for inquiry or negotiations with other companies, can generally give an answer straight away; and there are often occasions when the great value of some desired concession depends on the promptness with which it can be given. In the chapter on "State $v$. Company Management" I have shown what the course of proceclure under like circumstances on a Continental railway may involve. I would remind the reader, also, of the incident recorded on page 88 , where it is shown that so simple a matter as the raising of a wooden partition in the booking office of a South African Government railway involved a correspondence extending over fiftyeight letters. 


\section{Rallways and Nationalisation.}

As an enterprise working on business lines and keeping closely in touch with industrial and commercial developments, a railway company ought, at least, to be always ready to consider any business proposition likely to bring them increased traffic or to develop a district in which they are interested, though they may not always see their way to comply with the requests brought before them.

In the matter of claims, again, traders may suffer many disappointments at the hands of companies who scruple to grant company's risk conditions for owners' risk rates, and are considered very unreasonable in consequence. But even in these instances-and apart from the numerous cases where compensation is granted though no legal claim exists-it cannot be denied that the trader rarely has to wait long for his answer.

Would the position of the traders be improved when they had to deal, not with a commercial company, but with high Government officials who might be less in touch with industrial and commercial developments, might not have the same capacity as trained railway men in dealing with traffic problems, and, even if they were not less sympathetic generally, would be bound by official routine and circumlocution in general? Admitting, for the sake of argument, that the trader has some really well-founded grievances now, would they be likely to disappear entirely 
under State ownership, or would nationalisation simply produce a fresh crop of a new variety?

\section{GERMAN TRADERS' GRIEVANCES.}

It is usual to say, as a convincing proof of the complete satisfaction of German traders with their present conditions, that "none of them would revert from State to company ownership." That may well be the case, if only because the reorganisation of a business built up on the basis of established transport conditions might in itself be a serious matter. But there is no lack of traders' grievances in Germany, the main difference being that, whereas the average German takes a pride in the institutions of his Fatherland, and is reluctant to admit to a foreigner, at least, that any fault can be found with them, the average Englishman is an inveterate grumbler, and is ever ready to discredit the railways which have done so much for the prosperity of his country.

Apart from what I have already said in Chapter VI. as to the inadequate " betterment" of lines and the insufficient supply of wagons, the main grievance of the traders in Germany in regard to their State railways is that, inasmuch as they are run too much with an eye to the eventual profits, there is too little disposition on the part of the State railways administration to reduce the rates and charges on domestic traffic. I say "domestic" because it is mainly these 
that are required to atone for the very small margin of profit that may be left on export rates kept abnormally low by the competition with neighbouring countries, or for reasons of State policy in fostering German trade abroad.

The expectation entertained at the time the companies lines were taken over that the profits would be utilised for the purpose of effecting substantial reductions in rates has thus certainly not been realised in the case of domestic rates in Prussia, at least, and the dissatisfaction resulting therefrom has been expressed by no less important a body than the "Centralverband Deutscher Industrieller," an organisation formed of representatives of the greatest industries in Germany, including coal, iron and steel, metal wares, textile fabrics, paper-making, \&c.*

A subsidiary grievance in Germany is that certain of the traders, and especially those dealing in fragile commodities, such as furniture, pottery, etc., sustain heavy losses by reason of the refusal of the State lines to accept transport of any goods " not properly packed" unless with a note relieving the administration of all responsibility in the case of damage. (See page 285. )

The length of time taken in the delivery of goods; the absence of railway warehouses on the English model; and the refusal of credit to

* See "German $v$. British Railways," page 50. 
traders are not grievances in Germany, because business there has been organised to meet the stated conditions. But these things might well become serious disadvantages here if, concurrently with State ownership, they were reproduced in the United Kingdom. Even, therefore, if the German traders had no grievances at all, and were absolutely satisfied with their own railways, their system would not necessarily be equally well adapted to our own conditions and requirements.

GERMAN RAILIVAYS FROM AN ENGLISH STANDPOINT.

The impression which the operation of the German State railways in general may make on an experienced English traveller is well shown by the following letter published in the Daily Telegraph of February 22, Igo8:-

TO THE EDITOR OF The Daily Telegraph.

SiR,-It would be very interesting to know what Mr. Lloyd-George finds to eulogise in German railways. As one who has had fifteen years' experience of them, I have no hesitation in saying that cur own for speed, comfort, and frequency are superior to any on the Continent.

Nationalisation on the basis of the present railway capital would prove a bad bargain for our nation. Third-class carriages in the Fatherland have hard wooden seats, and on very few fast longdistance trains is there any third class at all! The service is only half as frequent as ours and the fares only a trifle lower. They have been raised twice during the last few years, and the Government 
regards the railways as a money-earning concern to produce revenue. If anyone thinks that a Government runs railways for the benefit of the public he is much mistaken. Goods trains are both infrequent and notoriously slow. At least three days must be allowed for roo miles for a wagon-load. Urgent goods are not recognised unless one pays double freight. Cheap excursions, which delight thousands in this country, are unknown; week-end tickets do not exist. Mineral traffic for ninety miles, in ten-ton lots, costs 9s. per ton, which, I think, in this country we can easily equal.

Finally, the red-tape is atrocious. Any unfortunate wight who rides past his station is mulcted in the difference and fined $6 \mathrm{~s}$. on the spot. No excuses are available. Onc must pay forthwith. If you overload a goods wagon you are fined pounds for a few hundredweight put in on a dark winter evening to cmpty a rulley. Demurrage is relentlessly enforced, and you are made to feel that you are dealing with permanent Government officials who do not give a straw for your convenience. In busy times one must give at least twenty-four hours' notice to secure a wagon. Consignment notes are purchasable at every bookseller's, and are rendered as accounts at the other end. I once had a parcel of I cwt. from Stassfurt to Hamburg, and when it arrived the note was stamped and countersigned by no fewer than twenty-two different persons! It is worth framing as a curiosity.

Our corridor trains running North cannot be equalled for comfort and cheapness in any country in the world, and oppressive goods rates could casily be altered by legislation. If certain people get our railways nationalised and see the result a year afterwards they will be sorry they spoke.

Yours truly,

W. A. BRJGGS.

I I, Leadenhall Strcet, E.C., Feb. 13. 


\section{BELGIAN TRADERS' VIEWS.}

In Belgium there is a good deal of discontent among business men at the way in which the State railways there are administered, and especially in respect to the uncertainty concerning the real financial position of the lines, the pressure brought to bear on the Government to make all sorts of concessions to workers and others, and even in regard to the rates, and more particularly domestic rates. These various grievances have been voiced by the "Féderation des Associations Commerciales et Industrielles de Belgique," which body, in asking what is the possible remedy for the conditions in question, has said :

It is much to be feared that, notwithstanding the declarations so precise of the (Railway) Minister, these abuses will last as long as the railways are operated by the State, and controlled by a politician who must always be subject to demands and pressure of all kinds-without reckoning the established fact that in all countries operation by the State is more costly. It may be that, the position being thus, the solution of the problem will have to be found in the system adopted in Holland.

That is to say, in the operation of the Stateowned lines by a private company.

AUSTRALIAN TRADERS' GRIEVANCES.

Turning from Europe to Australia, to see if 
the traders at the Antipodes are thoroughly satisfied with the way in which the railways are managed there, I find in the Pastoralists' Review (Melbourne) of December I6, I907, some letters from Mr. A. M. Pearse, secretary of the Stock Owners' Association of New South Wales, and Mr. F. M. Rothery, secretary of the Animals' Protection Society of New South Wales, which certainly do not suggest that Government operation of the railways in Australia is altogether beyond reproach. So slow, it seems, are the New South Wales cattle trains that it takes about four days for live-stock to be carried a distance of, say, 500 miles; and so defective are the railway arrangements that the animals thus brought down to the coast from the interior stand in the trucks without being given a scrap of food or a drop of water during the whole of those four days. "In the height of the summer," Mr. Rothery remarks, "with a temperature of from Ioo to I05 degrees in the shade, one can readily imagine the terrible suffering of the stock." Nor is it the unfortunate animals alone who are prejudiced by these conditions. One has also to consider the interests of the meat consumers, for the latter, Mr. Rothery says, "little know of the danger hidden in the veins of the cattle maddened with the agonies of thirst, a danger that permeates and poisons the whole carcase before it is drawn off at the abattoirs. . . . . No wonder," he declares, "there are at the present day so 
many ailments among our people that years ago were unheard of.'

The grievance in question is in no way a new one. "Year after year goes by," says Mr. Pearse, "and the same complaints reach us. . . . . In Argentina, where the railways are owned by private companies, and where in everything relating to carriage of passengers or stock they are years in advance of us, the law is that no stock may be in a railway truck more than twenty-four hours. If that time is reached, the railways, at their own expense, must take them out, feed and water them, and give them a spell before re-trucking them."' Mr. Pearse adds :"The stock agents and this Association have brought the matter many times under the notice of the Government, but no change has ever been made. The losses are terrible year after year, and the sufferings of the poor animals most inhuman."

In the United Kingdom there could be an immediate appeal, under such conditions as these, to the Board of Trade, or the railway companies themselves might be prosecuted for cruelty; but when the railways are owned by the State there is no court of appeal and the traders are powerless.

In a later issue of the Pastoralists' Review, that for February 15, 1908, mention is made of the delays that occur in New South Wales in obtaining railway trucks for the removal of stock 
to other stations when there is a deficiency of food on their regular pastures, and it is stated that in two instances six weeks elapsed before the trucks could be obtained, the result in one case being that over $f_{1}$,ooo had to be spent in fodder, besides payment of rent for the land which had been arranged for. The excuse offered by the Railway Commissioners was that "they would not be justified in having vehicles available to expeditiously meet all demands "; but they have now ordered a further supply of wagons.

Whatever, then, the real nature of the British trader's present grievances, it is evident that, in trying to get rid of them by means of railway nationalisation, he might only change them for others of a different kind; while the actual experiences of other countries which already have a State railway system certainly do not suggest that, by following their example, he would be left with no grievances at all. 
Continental Transport Conditions. 253

CHAPTER XI.

\section{CONTINENTAL TRANSPORT CON- DITIONS.}

Much of the adverse criticism of railway rates and charges in the United Kingdom is based on comparisons with the rates and charges in force on railways in Continental countries. But I would suggest that no such comparisons can fairly be made unless one bears fully in mind the nature of the general transport conditions by which the Continental rates and charges may be governed.

Taking the case of Germany, Belgium, Holland, and France, with which the comparisons in question are, as a rule, more especially made, I would remind the reader that these countries form the western fringe of a great continent, and that, apart altogether from the traffic they originate themselves, they constitute the gateways through which vast quantities of commodities pass between Central Europe in general and the countries beyond the seas. Railway managers or directorates in the border-lands of that continent have, therefore, not only to meet the requirements of home producers and home consumers, but, if they wish (as they naturally do) 


\section{Railiways and Nationalisation.}

to achieve as great a commercial success as they can for the systems they control, they must strain every effort to secure as large a share as possible of this transit traffic and of the profits arising therefrom. The sum total of such traffic is prodigious, and the proportions that are secured by the aforesaid border-lands represent a very important element indeed in their railway business. This is especially the case with Holland and Belgium, whose economic conditions would be entirely different from what they are if those countries formed separate islands, and if their railways were dependent on the transport of Dutch or Belgian traffic exclusively.

\section{PROPORTIONS OF TRANSIT TRAFFIC.}

As regards the possible extent of the transit traffic passing through Continental countries, one can gain some idea of its magnitude from figures bearing on the subject given by Sir Cecil Ilertslet, Consul-General for Belgium, in his report on the trade and commerce for Belgium for 1906 and the first half of 1907 . He says :-

The returns of the transit trade of Belgium for the year 1906 show a large increase over those of the previous year. In that position which it occupies geographically Belgium is so placed that large quantities of goods are exported and imported through it by foreign countries. Goods emanating from Germany, Switzerland, and France are exported by way of Antwerp principally, and vice versâ 
large quantities of merchandise are imported through Belgium destined for those countries which form the hinterland of Antwerp.

The figures for goods in transit during 1906 amounted to $4,406,100$ tons, the value being E.90,756,000, compared with those for the previous year, which amounted to $3,692,600$ tons of a value of $E 76,892,000$, the respective increases being $19 \% 3$ and 18 per cent., while the actual augmentations amounted to 713,500 tons in volume and $£_{1} 13,864,000$ in value. During 1906 the transit trade was chiefly in connection with the German Customs Union, France, the United Kingdom, the United States, the Netherlands, and Switzerland, either in goods emanating from those countries or destined to them.

There is the greater need to bear these very material considerations in mind because a tendency has been shown in certain Ministerial quarters to attribute the prosperity of Continental countries actually engaged in handling such international traffic as this to their possession of State railways, rather than to geographical and economic factors to which the ownership of the railways by the State, instead of by private companies, is altogether subordinate.

No possible changes we could ourselves make in regard to the operation of our railways-or even the improvement of our ports-would be likely to induce these border-lands of the Continent to neglect, in our special interests, the advantages they derive alike from their geographical position and from their now being able to do a direct trade with distant lands instead 
256 Railiways and Nationalisation.

of through the Port of London, as in days that are past. If this be so, then any attempt to concentrate public attention unduly on the existence of State railways in connection with the development of Continental ports, and to leave these other matters out of consideration, is, surely, equivalent to a misdirection of the jury.

\section{HOLLAND AND WESTPHALIA.}

The fact that private enterprise was in no way remiss in promoting trade and transport on the Continent long before State railways became an active force there, is well shown by certain events in the history of Holland which, already told in " Railways and their Rates," may here be appropriately recalled.

Half a century ago two English railway men --the late Mr. James Staats Forbes and Mr. D. G. Bingham-were engaged to go to Holland and do what they could for the Dutch-Rhenish Railway, whose fortunes had fallen so low-on account, mainly, of the water competition-that its shares no longer had any market value. About the same time, an Irishman, the late Mr. William T. Mulvany, formerly Commissioner of Public Works in Ireland, had started some colliery companies in Westphalia, and he and the two Englishmen met to consider what they could do to promote the interests of their respective concerns. In the end the railway men agreed 
that, if Mr. Mulvany would load his coal into railway trucks instead of into river barges, they would haul it in regular train-load lots from Westphalia to the port of Rotterdam at rates which (apart from questions of convenience) would compete with the water rates, the wagons bringing the coal to return with iron ore for the Westphalian ironworks. The traffic thus created gave a stimulus to the early development of one of the most important coal-fields in Europe; it established the prosperity of the Dutch-Rhenish Railway, for which system the Dutch Government paid generous terms when taking it over in I900; and it laid the original foundation of that wealth which $\mathrm{Mr}$. Bingham, who still happily survives at Utrecht, is now lavishing on wisely-planned benefactions for his native town of Cirencester.

\section{WATER TRANSPORT.}

It is true that a large proportion of the international traffic is carried by water, and that Rotterdam owes her prosperity mainly to the commerce which passes along the Rhine to or from Germany and the countries beyond. But this very fact only accentuates the keenness of the scramble for the traffic, and it leads the competing railways to reduce their export rates to exceptionally low proportions when there is any prospect at all of their being able to prevent too much of the business going to the waterways. 
To illustrate the magnitude of this Rhine traffic, I might give some figures from the report of the Rotterdam Chamber of Commerce for 1906. The total Rhine traffic across the German-Netherlands frontier in that year was as follows : - With the Netherlands, 16,331,265 tons; with Belgium, 4,821,229 tons; Rhine sea - traffic to or from English, Russian or other ports, 357,200 tons ; total, $21,509,694$ tons. Of the $16,33 \mathrm{I}, 000$ tons to or from the Netherlands, in 1906, Rotterdam's share was 13,357,000 tons. In 1905, Rotterdam's total Rhine traffic was $12,771,000$ tons; in 1904, ro,684,000 tons; in 1902, 8, 197,000 tons; in $1900,7,845$,000 tons; in $1898,6,449,000$ tons; and in $1897,5,914,000$ tons.

These figures throw light on (I) the extent to which the border countries of the Continent depend on foreign trade for their traffic; (2) the intensity of the competition between water-borne and rail-borne transport; and (3) the jealous eye with which Prussia regards the diversion of so much German traffic to neighbouring countries.

One hears much concerning the great commercial expansion of Germany; but every fresh I, ooo tons added to her production in the Westphalia and Rhineland districts probably means an increase, more or less, in the Rhine trafficeither in raw materials or in manufactured articles-passing through the ports of Rotterdam or Antwerp, Holland and Belgium thus sub- 
Continental Transport Conditions. 259

stantially tapping the increase in prosperity which Germany would fain keep for herself.

\section{WATER $v$. RAIL IN HOLLAND.}

In Holland, 9o per cent. of the goods traffic of the country goes by water, and the railway receipts from goods are only slightly higher than those from passengers. How this compares with the corresponding percentages for Prussia-Hesse and Belgium for the year 1906 is shown by the following table:-

Railway System.

Receipts (in marks) per kilometre. From passengers. From goods.

Prussian-Hesse State railway Belgian State railway Holland (entire system)

$14^{\circ}, 060$

$13^{\circ} 541$

14.865

$35^{\circ} 204$ $33 \cdot 319$ $15^{\circ} 604$

\section{THE RHINE-SEA TRAFFIC.}

Concerning the Rhine-sea traffic to which I have already referred, I might explain that there are sea-going steamers which load at Rhine ports up to Cologne and proceed thence without transhipment either to German seaports or to ports in England, Sweden, Russia, etc. They carry on a direct coasting traffic which competes very materially indeed with the Prussian State railway system. According to the report of the Central Conmission for the Navigation of the Rhine, as 
quoted in the "Annales des 'Travaux Publics de Belgium," for February, 1908, the amount of this Rhine-sea traffic in 1906 was 334,636 tons (or slightly less than the figures given in the Rotterdan report), the total being made up as follows:-Traffic between Rhine ports and Bremen, I2,80I tons; Hamburg, I8I,194 tons; Stettin, 22,258 tons; Dantzig, 19,722 tons; Königsberg, 15,05I tons; other German ports, 36,717 tons; English ports, 36,539 tons; Russian and other ports, 10,354 tons. It will be seen from these figures that the bulk of this river-sea traffic is between Rhine ports and Hamburg.

Thus the Prussian State railways are concerned not alone in the Rhine traffic that goes to neighbouring countries, but also in that which goes direct to German ports for shipment abroad, or for local consumption, without, it may be, touching the railway at all. The magnitude of the Rhine traffic as a whole is shown by the fact that in 1906 it amounted to $59,677,000$ tons, while the total number of vessels engaged in the transport thereof was 10,736 , including 1,286 steamers, and $9,45^{\circ}$ barges or sailing ships. In the same year $\mathcal{E}_{\mathrm{I}} 7 \mathrm{I}, 300$ was spent in the various States on river improvements, and $\mathcal{E} 686,750$ on the Rhine ports.

Apart, therefore, from the other great natural waterways of Germany, and taking the considerations offered by the Rhine alone, I would suggest that it is impossible to arrive at a com- 
plete understanding of railway rates in Germany unless one bears in mind how powerfully they may be influenced by this question of water competition within the limits of the German Empire itself.

COMPETITIVE ROUTES.

Then we have the further geographical fact that for a very large part of this transit traffic to or from the countries of Central Europe there is a choice of routes, the leading ports of several, if not sometimes of all, the border-lands mentioned being equally available. Even if the French ports should not be able to compete as regards commodities to or from the more northerly countries, there would still be the keenest rivalry between the North Sea ports alike of Germany, of Holland, and of Belgium, the difference between which in respect to distance and convenience might be comparatively slight.

A good example of the competition for traffic which may go on is afforded by the city of Nuremberg; which is the centre alike of Germany and of Western Europe. Nuremberg is the same distance from Hamburg and Bremen, on the north, as it is from Trieste on the south; Antwerp, Rotterdam and Stettin are also equidistant; Genoa is but a few miles further than Amsterdam; while, including Ostend, Dunkirk, Calais, Boulogne and Dieppe within the same. radius as Havre, it will be found that there are 
fourteen ports in six different countries-Germany, Holland, Belgium, France, Italy and Austria--which might compete for over-seas traffic from this one German city.

For the busy manufacturing districts of Westphalia the nearest, and therefore the natural, port is either Rotterdam or Antwerp; and, if railway rates were fixed solely by considerations of distance, the German ports of Hamburg and Bremen would have no chance of competing with the Dutch and Belgian ports in respect to this traffic in Westphalian commodities. The result would be a loss of business alike to German railways and German ports, to the benefit of foreign railways and foreign ports.

\section{EXPORT RATES.}

It is to prevent these consequences that the Prussian State railways concede exceptionally low rates from various manufacturing centres in Germany, and especially in the Rhine district, for goods consigned to Hamburg or Bremen for export. Such rates are often spoken of as "bounties on export," granted by the Prussian Government in the interests of German commerce and the German trader. To a certain extent they are; but I would suggest that they have been conceded much more in the interests of traffic on the Prussian State railways, and hence to the direct advantage of the Prussian 
Continental Transport Conditions. 263

Exchequer, which benefits from the railway profits.

The individual German trader is concerned only in finding the cheapest route for his goods, and, apart from this consideration, it is a matter of detail for him whether he consigns to a foreign country viâ Rotterdam or Antwerp, or viâa the Prussian State Railways and Hamburg or Bremen. But his choice is of material concern to the State railways, should they lose the traffic they would like to carry.

So the export rates conceded by the State railways administration are governed more or less by either the water competition or the shorter rail route viâ a neighbouring country; though these export rates are always substantially lower than the rates to the same ports for commodities intended for local consumption, the difference in some cases being one of 20 per cent. Comparisons are systematically made between such export rates in Germany and ordinary domestic rates on British railways; but the unfairness of any such comparison is obvious.

THE DORTMUND-EMS CANAL.

Export rates of the type in question were in force on the Prussian railways before these were acquired by the State, and they were continued and developed by the Prussian Government; but vast quantities of German export traffic still went 
by the Rhine to the foreign ports. Then, at the personal instigation, as is understood, of the Emperor himself, the Dortmund-Ems Canal was cut, at great expense, so that water could compete with water. Instead, however, of diverting traffic from the Lower Rhine, the DortmundEms Canal has hitherto, and pending its further extension to the Rhine, mainly served the purpose of providing a fresh inlet for English coal and Swedish iron, and the transit traffic through Rotterdam and Antwerp is to-day greater than ever. In the face of these very material facts, therefore, I would invite transport reformers to conclude that in endeavours to effect material changes in economic laws even the will of a powerful Emperor may be of no real avail.

\section{THE STATE AND THE TRADER.}

I have suggested that the Prussian Government were much more concerned in endeavouring to retain German traffic for Prussian railways and Prussian seaports than they were simply in benefiting the German trader. 'This is shown by the fact that while the Prussian State railway administration gives very low rates indeed to the German North Sea ports in order to capture the traffic, it carefully avoids giving similarly low rates from the same points of dispatch to the river Rhine. In the former case one hears much as to what the Prussian Government do for the trader. 
Continental Transport Conbitions. 26.5

But if the interests of the trader should clash with those of the Government-that is to say, should he desire exceptional rates so that he can send his commodities to a Rhine port for convey, ance to Rotterdam by water, instead of giving the State railways a long haul to Hamburg-he will get no such concessions. In such circumstances as these the German trader is left to his own resources. Strong complaints have been made on this subject by traders in the district concerned, and a Statement which has been drawn up, setting forth their grievances in respect to "the differential treatment of the German Rhine ports, as compared with NorthSea ports, in the goods tariffs of the Prussian State railways," occupies no fewer than 24 closely-printed foolscap pages.

THE STATE AND THE CANALS.

In Germany, again, the construction of new canals is imperative, especially in Westphalia, owing to the fact that, under State management, with its accompaniment of State economies for the benefit of the State exchequer, the railways have not undergone development commensurate with the growing needs of trade and commerce. The Government approve the construction of the canals, but they want to have the right to impose on the canal traffic such tolls as they think fit, nominally for the purposes of raising better- 
ment funds, but more especially to enable them to control the use of the canals, so that, while these afford relief to the State railways, they shall not compete unduly with them, to the detriment of the railway revenue.

To give increased facilities to the trader is one thing. To risk a decrease in the Government receipts from the railways is another. If the former can be done without involving the latter, well and good. But in the present condition of their national finances the Prussian Government must regard political considerations as paramount. When in Germany the interests of the State come to the front, those of the trader go to the background; and this must necessarily be the case whenever the national and the State railway accounts are more or less united.

\section{THE LEVANT TARIFF.}

Then for the southern and the south-eastern portions of the German Empire the nearest route to the markets of the Levant would be viâ Trieste or the net-work of railways on the east of Germany to Constantinople and Black Sea or Mediterranean ports. But the Prussian State railways have arranged a German Levant tariff under which abnormally low rates are granted in order to retain the traffic in question alike for German railways, German ports, and German ships. The further the point of dispatch from 
Hamburg or Bremen-and, consequently, the greater the competition with Trieste, etc.-the lower do these through rates become, so that goods will even be carried from points in the south-east of Germany, viâ Hamburg or Bremen, to Constantinople, Alexandria, and other ports at an even lower rate than would be charged for taking the same commodities to Hamburg or Bremen only, when they were not intended for export.

For example, the "domestic" rate for goods not specially classified, from Salzburg to Bremen, a distance of 562 miles, is $55 \mathrm{~s}$. $6 \mathrm{~d}$. per ton for ten-ton lots when those goods are for local consumption; but if the goods are consigned from Salzburg, viâ Bremen, to a port in the Levant, the through rate is $53 \mathrm{~s}$., or $2 \mathrm{~s}$. $6 \mathrm{~d}$. per ton less than if the consignment goes to Bremen only. For five-ton lots the corresponding local rate is $62 \mathrm{~s}$. $8 \mathrm{~d}$. per ton, as compared with $55 \mathrm{~s}$. Iod. for the through rate, or 6s. Iod. per ton less from Salzburg, viâ Bremen, to (say) Alexandria than from Salzburg to Bremen only.

\section{DIVERTING THE TRAFFIC.}

Rates of this kind are ostensibly given in the interests of the German trader. But once more we find that such apparent concessions may, in many instances, be made still more in the interests of the Prussian State railways. That is 
to say, they are designed to cnable the Prussian State system to divert from its natural course traffic from the south of Germany which the North German lines and ports would otherwise not have a chance of handling. By such diversion the Prussian State railways get a long haul across the full extent of their lines; and though, owing to the competition of those alternative and shorter routes by which their through-rate is governed, the Prussian State railway administration has to be content with a modest return as its proportion of that through rate, such return probably yields a profit all the same.

The actual proportions of the through rates paid to the railways and to the steamship companies respectively are jealously regarded as State secrets, and cannot, therefore, be told.

\section{INTER-STATE COMPETITION.}

Alike in the case of the Levant tariff and in that of other special tariffs in force in Germany, one system of State railways may be competing most actively with another group of State railways within the limits of the empire, and many of the exceptionally low rates are granted expressly to meet those conditions. There is, naturally, a benefit to the trader who is the object of this rivalry; but what the State railways mainly seek is to capture the traffic for their own lines. 
The Prussian State railways, for example, will give no transhipment rates at the Rhine ports of Ruhrort and Duisburg, because such rates would facilitate Rhine traffic, to the detriment of the Prussian railways and seaports and to the benefit of Rotterdam. But transhipment rates for Rhine cargo--such, for instance, as minerals for Bavaria, iron and steel for Switzerland, and petroleum for Würtemberg-are readily conceded at Mayence and Frankfurt, when it is a matter of capturing the traffic for the Prussian State lines at those points, instead of allowing it to proceed further along the river, and pass on to the State railways of Baden, without touching those of the Prussian-Hesse system at all.

\section{INTERNATIONAL COMPETITION.}

When the rivalry extends to different countries it becomes so keen that in France, for example, special rates applying to transit traffic from Italy or elsewhere which might pass through Belgium, Holland or Germany unless secured at once for the French railways and a French port, can be brought into immediate operation should the Railway Minister raise no objection within twenty-four hours; although if the domestic trader wants some concession he may have to wait six months before his request can pass through all the official routine.

The rivalry and the competition between the 
different State systems themselves on the Continent of Europe are factors of primary importance in the railway and general transport conditions there; but they obviously could not be reproduced in the British Isles, should a resort to the Continental principle of State ownership be resolved upon. Under State ownership here we should have neither the Continental transit traffic nor the advantage of the influence which interState or international conditions exercise-to the advantage of traders-on Continental State railway administrations.

RAILWAY RATES AND PROTECTION.

There is the further consideration, to which I have already alluded, that Continental railway rates, especially those applying to exports or imports, may be fixed much less on ordinary transport principles than to meet political or fiscal conditions.

As typical of the part which railway rates play in the protection policy of Gernany, I might mention that, some years ago, when there was a poor fruit harvest in Holland, the German growers did a good business in sending large quantities of fruit to Dutch preserve-makers, being helped so to do by exceptionally low export rates on the Prussian State railways to the Dutch frontier. In the following year fruit was plentiful in Holland and scarce in Germany; but 
when the Dutch growers wanted to dispose of their surplus, they found that the rates from the frontier to various points in Germany had been fixed by the Prussian State railways at so prohibitive a figure-in order to protect the German growers against foreign competition-that the market there was practically closed to them, and they had to look to doing a bigger trade with England instead.

\section{LENGTH OF HAUL,}

The Continental railway traffic, again, differs materially from that in the United Kingdom in respect to that element of length of haul which has so material a bearing on the question of rates, when looked at from the point of view of amount per ton per mile, and especially when comparisons are made with the traffic in countries where only short hauls are possible. This, of course, was the important consideration which did so much to nullify the comparisons made a few years ago between American and British railway rates; but the same considerations arise as between this country and the Continent of Europe. In the German Empire there are rates in operation for hauls such as the following :-

Coal, from Mysowlitz (Prussian Silesia) to Neubrandenburg (near Stettin), 394 miles;

Tin plates, steel plates and steel rails, from Breslau to Emden, 494 miles; 
Pig iron, from Algringen, Alsace-Lorrain , to Breslau, 6.32 miles;

Grain, from Breslau to Friedrichshafen, 566 miles; and

Flour, from Breslau to Wangen-i-Algau (Bavaria), 553 miles.

The average length of haul in Germany is over seventy miles. In Great Britain it is only about thirty. The terminal charges remain the same whatever the distance the consignment is carried, and these, in the case of a short haul, would alone suffice to make the cost per ton per mile appear much higher than in the case of a substantially longer haul.

\section{RAILWAY LOADING.}

Supplementing the factors of heavy transit traffic and of length of haul, there is the important consideration as to the bulk in which consignments are carried. In the case of Germany some figures bearing on this point, together with the average receipts from the various classes of traffic, are contained in the following table, which I take from the official report* of the Prussian-Hessian State Railway system for I 905 :-

* "Bericht über die Ergebnisse des Betriebes der vereinigten preussischen und hessischen Staatseisenbahnen im Rechnungsjahre 1905. 
Continental Transport Conditions. 273

Goods Traffic on the Prussian State RAILWAYS DURING THE YEAR I905.

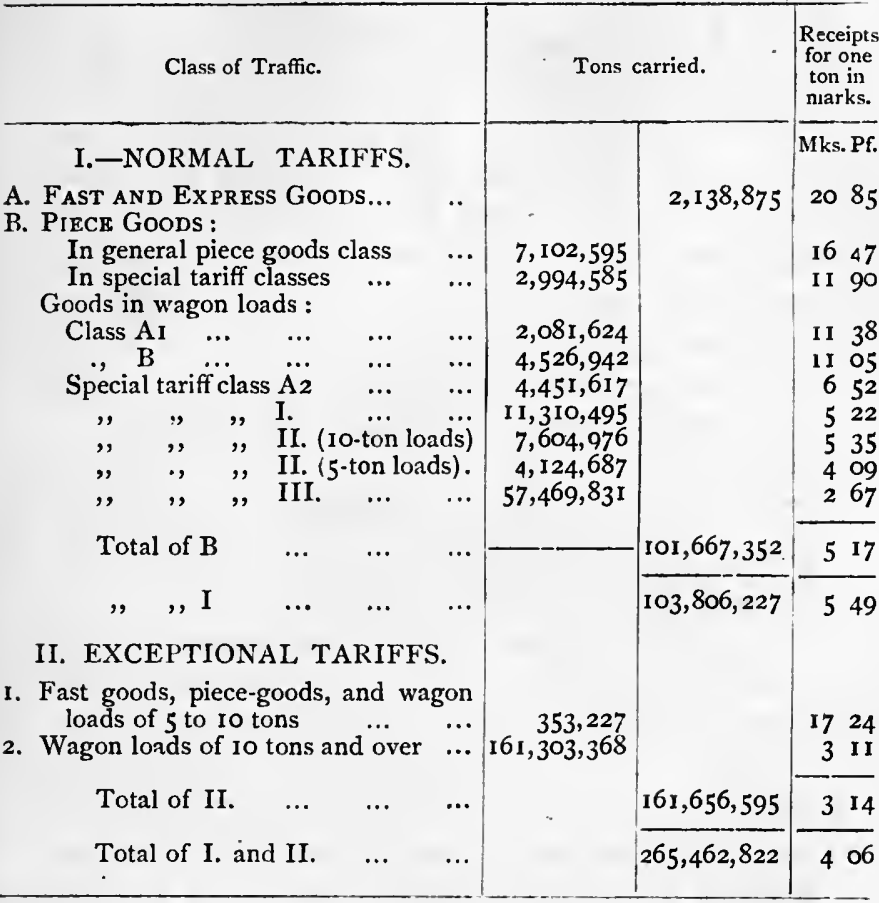

This table shows, in effect, that the total weight of the goods consigned by the PrussianHessian State railways during the year 1905 was $265,462,822$ tons, of which quantity $2,138,875$ were carried as fast or express goods, and $10,097,180$ as piece goods, while the remaining. 
$253,226,767$ tons, representing nearly 95 per cent. of the total, went either in wagon loads or in five or ten-ton lots.

The large proportions of this percentage of big loads are due to various factors, such as :-

(I) The application of special or exceptional rates to quantities of not less than five tons; whereas in the United Kingdom such rates are often extended to quantities of only two or three tons, traders here working down to this standard, and making more frequent consignments on the lower basis, where the German trader would consign less frequently, but on the five-ton or tenton basis.

(2) The collection of goods from the German traders and others by forwarding agents who make up (by combination, when necessary) five or ten-ton lots, thus gaining advantage of the lower rates available, and, nominally, at least, sharing that advantage with their patrons.

(3) The fixing of the legal time limit for the transport of goods (within which period the railway is not to be responsible for delay) on so generous a scale that the railway people are able to keep back ordinary consignments for one or two days, if necessary, in order to secure better loading, higher rates on the fast or express scales having to be paid by senders of consignments for which immediate delivery is required.

From a railway standpoint the working expenses can naturally be kept lower when so large 
a proportion of the traffic is carried in big loads; and although there is certainly a good deal of traffic in bulk on the English lines, the conditions of trade have led more especially to a frequent despatch of small or comparatively small individual consignments, each requiring separate handling.

\section{CONSTRUCTION : WORKING EXPENSES.}

There are still other conditions which have operated to the advantage of - most of the Continental railways.

(I) As a rule they have not been bled so mercilessly in the acquirement of their land as has been the case with railways in the United Kingdom. In and around the large cities land has naturally been expensive; but neither there nor in the country districts have land-owners been able to insist on the payment to them of exorbitant sums, especially by Governments constructing State lines.

(2) The Continental railways have saved on that item of Parliamentary proceedings which has often involved railway companies in the United Kingdom in so formidable an expenditure. The construction of a new line of railway by the Prussian State Railway Administration costs nothing at all in the way of Parliamentary proceedings. The preliminary arrangements are a matter of ordinary office expenditure, unless 
any person whose land it is proposed to take should refuse to come to terms, in which case there is a resort to arbitration.

(3) The expenditure on actual construction of railways in most of the Continental countries, and especially in those of Northern Europe-but excluding lines in mountainous districts-has been comparatively low. A physical map of Europe will show that from the coast of Holland there is a level plain across Germany and Russia until one comes to the Ural Mountains, on the eastern extremity of Russia in Europe. From the Hook of Holland to Berlin there is not a single railway tunnel. There are important bridges over rivers, and a costly overhead line has had to be constructed in Berlin itself; but in the whole of North Germany there is not, I have been assured, a single railway tunnel. Even cuttings and embankments are rarely seen. These "level plain" conditions are to the advantage, not alone of cost of construction, but also of working expenses, inasmuch as a locomotive can naturally haul a heavier load on the . flat than it can up a series of steep gradients.

(4) Nor, in Continental countries, is there any exact equivalent to our Board of Trade-a body requiring that railways shall be constructed from the very outset with an absolute perfection of completeness in every detail, and insisting on a variety of requirements which, however desir- 
able, undoubtedly add considerably to the cost both of construction and operation.*

(5) The general absence of fencing; the sparse provision of footbridges; the numerous level crossings (often protected only by poles worked with weights); the passing of trains along the streets of a city (as in Hamburg); the non-use of "chairs" in the laying of the rails: these and other economies found on the Continent remind one far more of the average American rather than of the ordinary British railway, and they must have tended still further to keep down the cost of providing the lines.

\section{WHAT THE RATES INCLUDE.}

Thus, as I have shown, there is a multiplicity of factors influencing Continental railway rates - the competition of different countries for a vast volume of transit traffic which may often pass equally well through any one of them; the competition with the railways of great natural waterways and canals; the desire of State railway administrations for a maximum of possible profit; political considerations in fostering commerce and influence abroad and protection of industries at home; hauls of such length that unless the traders got low rates they would be shut out from the markets of the world; consignments

* See, in this connection, the reference to the Board of Trade and the Irish railways, on page 344 . 
in such bulk that they can naturally be carried on the most favourable terms; and railways that have themselves cost far less to construct than the railways of the United Kingdom. All these things go to make up a complex set of conditions which have no parallel here; and yet the rates charged by the Continental, and especially by the German, railways are incessantly being compared with British railway rates, these being adversely criticised-and even held up as a reason for the immediate nationalisation of the British railway system-if they should appear to be higher.

I say " appear to be higher" because, apart from the considerations already advanced, it may happen that a rate on this side, for a like distance, will include services which are not included in the corresponding Continental rate; so that here, again, comparisons would be misleading.

In the first place, the Continental rate might, and often would, be exclusively for haulage from one point to another, and would not include collection, delivery, loading, unloading, and wharfage or warehousing, which the Continental trader would have to provide, or pay for as extras.

COLLECTION ANI DELIVERY.

It is true that on the Southern railways in England nearly the whole of the ordinary goods 
traffic is conveyed at "station-to-station" rates, in which collection and delivery would not be included, while in the case of nine of the principal companies, operating mainly in the Midlands and the North, the goods traffic (exclusive of minerals) conveyed at special station-to-station rates is about 74 per cent. of the whole. In Scotland the proportion is 67 per cent. But these figures still allow for a considerable volume of traffic-more especially in London and in the great industrial centres-which is collected and delivered, and the arrangement under which the railway van calls for goods at warehouse or factory (whether by arrangement or on the display of a card at the door), and takes away goods which will be delivered direct to the consignee at the other end, at an inclusive railway rate, must be a great convenience to many a British trader. So far does the practice prevail that in a paper read at the Paddington Debating Society, Mr. H. C. Law, Superintendent of the Paddington goods station, mentioned that the Great Western Railway Company have at that depôt alone nearly I,ooo men and boys and 700 horses.

The Prussian State railway administration save expense by leaving the trader to make his own arrangements for collection and delivery, and they may, therefore, be able to charge a lower rate on the corresponding class of traffic. But the work of collection and delivery has to be 
done, and the trader can make his own calculation as to whether it is to his advantage to let the railway company render this service to him, as part of an inclusive rate, or whether he could do it more cheaply himself if he paid only a stationto-station rate. In any case, a fair comparison of the British and Continental charges turns in part on the question as to "what the rates include."

\section{LOADING AND UNLOADING.}

In regard to loading and unloading a distinction is made in Germany between (I) goods in less than car load lots ("Stückgut"), and (2) car load lots ("Wagenladung"). In the former case the consignments are both loaded and unloaded by the railway. When unloaded they are stored in the goods sheds until called for; but, unless they are fetched within twenty-four hours, a charge is made for storage. Intimation of their arrival is sent to the consignee by postcard-the cost of which, I might add, must be paid for by that individual, just as the consignor must already have paid for his "Frachtbrief," or consignment note (given to traders free of charge in the United Kingdom), at the price either of I pfennig per note, or 75 pfennig (9d.) per Ioo. When car load lots are despatched neither loading nor unloading is done by the railway unless paid for extra. Should the unloading not be completed within twenty-four 
hours (or even within less time, if the wagon is wanted) penalties are exacted as follows: For the first twenty-four hours 2 marks (2s.) per wagon; for the second twenty-four hours 3 marks ( $3 \mathrm{~s}$.) per wagon; for each succeeding period of twentyfour hours 4 marks (4s.) per wagon. Similar charges are made should the loading of the wagon not be completed within twenty-four hours from the time at which it is placed at the trader's disposal.

\section{WAREHOUSING.}

It follows from what I have already said that in Germany the trader gets no free wharfage and no free storage beyond the time given to him to remove his goods. The English practices of including in a railway rate a certain period of free storage (with subsequent moderate charges) in large warehouses provided by the railways for that purpose (so that many traders do not rent warehouses of their own), of giving free wharf. age to London coal merchants and others, or of allowing coal, hay or straw a substantial free period in the trucks, thus facilitating the operations of the trader in disposing of these commodities, are unknown in Germany, where the abuses once practised by certain classes of English traders-and still not unknown-in regarding railway trucks as free warehouses on wheels, would be impossible. 
GOODS TRAIN SERVICES.

In the next place the Continental rate might be for transport by a slow goods train, by which nothing like so quick a delivery would be effected as in the case of the ordinary goods service in Britain or Ireland. In Germany, for example, if it were desired that goods should be sent by rail at the same speed as they would be carried here, the trader would have to pay at least double, if not even fourfold, the ordinary goods rates in force in that country. The actual services in operation in Germany are as follows :-

Frachtgut (Slow Goods): Ordinary goods train service at published rates.

Eilgut (Express Goods): Faster goods on main routes supplemented by slow passenger trains on other routes, at double published rates. Schnellzugs-eilgut (Accelerated Express) : Fast passenger train, at four times the published rates.

The times allowed for Frachtgut and Eilgut consignments are :-

Frachtgut-

Day of handing in not counted.

For actual forwarding $\ldots . \ldots 2$ days.

For transit up to 62 miles ... ... 1 day.

Beyond 62 miles: for each 124

Eilgutmiles

Day of handing in not counted.

For actual forwarding $\ldots$. . 1 day.

For transit, each 186 miles ... I , 
On this basis no claim for delay could be made against a German railway if it carried a consignment at Frachtgut rates for a distance equal to that from London to Dublin within five days, though so long a time would not necessarily be taken in actual practice. Inspection of a number of consignment notes for the German State railways shows that while, for places on the direct route between Berlin and Hamburg, goods from either city would be delivered in one day, those to or from other parts of Germany, not on main routes, take up to six or seven days in delivery when only ordinary rates are paid.

In the circumstances, therefore, one must decide with which service on the Continental railways the rates in force here are to be compared; and I think it quite possible that by the time one has added to the German rate the actual cost, or value, to the trader of all that may be included in the British rate--collection, delivery, warehousing, express transport, and so on-but is not included in the German rate, it will be found that not only, as a rule, does the German "domestic" trader not pay less than the British trader, but he may even pay more.

Then, also, it is material to know whether the Continental rates with which comparisons are made are " export," "transit," or " domestic" rates (like being compared with like), and, also, in what quantities the goods in question are carried. It may happen that the Continental rate 
is for five or ten-ton lots, and applies to traffic carried in very considerable quantities (as, for example, complete train-loads of bacon or butter in Denmark), while the English rates that are quoted may, though still given as so much per ton, either apply only to very much smaller quantities of actual traffic, or, in fact, be "paper" rates for traffic in certain commodities not carried at all between the points specified, but for which lower rates would probably be at once given if there were any prospect of such traffic being handled.

\section{OWNER'S RISK.}

As regards owner's risk, I have already pointed out in my book on "German $v$. British Railways" that although the Prussian State railways do take the risk in regard to delays and breakages, the legal time allowance for delivery in the case of the ordinary services is so liberal that the limit should rarely be exceeded; while the railways guard themselves so thoroughly against the risk of breakages, by making such strict conditions in respect to packing, that the element of risk is reduced to a minimum. If there is the slightest suspicion that a consignment may, from the nature of the packing or from the absence thereof, get damaged in transit, thus throwing liability on the railway, the con- 
signor is required to sign a special declaration to the following effect :-

Special Declaration in Regard to the Packing of Goons.

The Goods Depôt of the Railway, at has, at my (our) request, accepted from me (us), for transport to , consignments which are indicated on the consignment note as follows :-

I (we) hereby expressly recognise the fact that these consignments are

unpacked, $*$

in the following respects not sufficiently packed, which condition has been duly specified on the consignment note.

(Signature and date.)

* The word " unpacked," or the words " in the following respects not sufficiently packed," should be struck out according to circumstances.

When I asked a forwarding agent in a large way of business in Berlin what was meant by the words " not sufficiently packed," he replied :-

In effect, general merchandise is regarded by the German railways as sufficiently packed only when it is in strong wooden cases, or, perhaps, in substantial baskets. Everything else must go on the declaration freeing the railway of all responsibility and leaving the trader to bear any possible loss.

Inasmuch, again, as there is only one rate in Germany, it will be seen that the traders who thus have to take the risk upon themselves get no reduction on account of "owner's risk" ; 
though they are able to insure the goods by paying more. In certain trades strong complaints are made by traders of breakages for which there is no hope of redress, the special declaration having been signed. The German State railways admit nothing but absolutely legal liability, and claims are made with far less frequency than is the case in the United Kingdom, because of the hopelessness of enforcing them unless the legal responsibility of the railway can be proved beyond the shadow of a doubt. As one German trader put it to me, "It is better to save the postage stamp."

FAIR COMPARISONS IMPRACTICABI,E.

Looking at all the various factors and conditions governing Continental as distinct from British transport traffic, it will be seen, I think, how very difficult, if not altogether impracticable, it is to make really fair comparisons between the Continental rates and our own. To state the situation in a single sentence: Continental railway rates are invariably based on conditions geographical, economic or political, which are not the same as those of our own country; and they are, also, often exclusive of services the addition of which-comparing export rates with export rates, and domestic with domestic-might well place them on an equality with our own, if not sometimes raise them to a still higher figure. 
Continental Transiort Conjitions. 287

\section{CONTINENTAL TARIFFS.}

Before leaving this branch of the subject I might further allude to the fact that one of the favourite arguments of the nationalisation party is that the system of tariffs on Continental railways is far simpler than is the case with the British railways. "In Germany," they say, "you give sixpence for two little books issued by the State railway authorities, and from these you can make your own calculations as to what you have got to pay." To imagine, however, that the two little books in question cover the whole ground of German railway rates is grotesquely inconsistent with the actual facts.

I have before me, as I write, a "List of Tariffs " in operation in Germany, issued by the Reichs - Eisenbahn - Amt, in Berlin. This "List"-giving merely name of tariff, date of issue, published price, number of supplementary appendices, and the place where it can be obtained-forms a book of 160 quarto pages, of which 150 are occupied by a catalogue of tariffs referring to rates for goods, live stock, and coal, the remainder relating to passengers, baggage and express consignments. It will suffice, perhaps, if I deal with the former only.

An analysis of the list shows that the number of railway tariffs in the German Empire in re. spect to goods alone is 708. They fall into three main classes: (I) inland tariffs, (2) tariffs 
for goods passing between Germany and foreign countries, and (3) tariffs for transit traffic going through Germany from one foreign country to another.

In the first of the three groups-inland tariffs -there are 209, and these, supplementing the general tariff, relate to nine different systems within the Empire-namely, the independent State systems for Prussia-Hesse, Bavaria, Saxony, Würtemberg, Baden, and Oldenburg; the Reichseisenbahn (Alsace - Lorraine); the Mecklenburg Friedrich Franz-railway, and the private railways. (Incidentally I would point out that a great mistake is often made in speaking of the railways of Germany as though they were all comprised in one and the same system. There is as much competition and rivalry between the different State railway systems in the German Empire as there is between different railway companies in the United Kingdom.)

The tariffs for consignments from Germany to foreign countries-Russia, Scandinavia, England, Holland, Belgium, France, etc.-number no fewer than $39^{2}$, while those for transit traffic number 107.

Of tariffs in respect to the transport of live stock-in the same three classes-there are 120 ; and of those relating to coal the number is 87 .

Thus a complete set of all the railway tariffs in operation in Germany would form a collection of 915 volumes. The cost per volume ranges 
from one halfpenny to $6 \mathrm{~s}$. The 708 volumes relating to goods cost $£ 35$ IIS. $3 \frac{1}{4} \mathrm{~d}$.; the 120

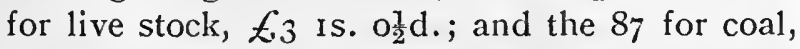
$E^{2}$ Ios. Iod.; the total cost of the 915 volumes being $E_{4}$ I 3 s. $1 \frac{3}{4} \mathrm{~d}$.

This great variety of tariffs has done much to strengthen the position of those forwarding agents who play so prominent a part in the transport of merchandise in Germany. Such agents are experts in the manipulation of the tariffs, and the average trader (unless, being in a large way of business, he keeps an expert of his own), generally prefers to leave them to solve his transport difficulties rather than undertake the task himself.

It has been suggested that the French system is better, because there the various tariffs are brought together in a single publication. This, of course, is the Recenil Chaix, issued every three months, in two massive volumes, the very sight of which would be likely to give a shock to the nervous system of the average British trader. Volume I, which contains the tariffs in respect to Grande Vitesse, has 986 pages, and weighs 5 lbs. The Petite Vitesse volume has 1,726 pages, and weighs $12 \mathrm{lbs}$. The total number of pages (the dimensions of which are $14 \frac{1}{2}$ by 10 inches) is thus 2,712 , and the total weight of the complete work is $17 \mathrm{lbs}$.

In Austria, also, the whole of the railway tariffs are brought together in a single work: 
published annually, supplements being issued from time to time during the year. But the work in question comprises 14 volumes, has a total of 6,ooo pages, and weighs 30 lbs. I4 ozs.

\section{RAILWAY FARES IN GERMANY.}

There is no need for me to enter upon any detailed comparison of British and Continental passenger fares and facilities. Such comparisons in regard to fares must needs be fallacious unless one remembers that third class travel on main lines of British railways is generally equal to second class on the Continent, and that, whereas here one can invariably go third class by express trains, on the Continent this is the exception rather than the rule. As against, also, any comparisons of ordinary fares must be put the very large number of excursion, tourist, week-end, market, or other special tickets issued here at reduced rates to an extent unsurpassed on any State railway on the Continent. All these are more or less familiar facts. But certain changes in railway fares in Germany have given rise to a misunderstanding which it may be desirable to clear away.

On October I, I906, a new tax, in the interests of the Imperial Exchequer, was imposed in Germany on railway, tramway, and steamboat tickets (with certain exceptions, such as in the 


\section{Continental Transport Conditions. 291}

case of school children), the amounts of the tax being fixed as follows :-

Ist Class. 2nd Class. 3rd Class

On tickets up to $2 M 1 \mathrm{k} . .$. Mk. $0^{\circ} 20$ Mlk. $0^{\circ}$ Io Mk. $0^{\circ} \circ 5$

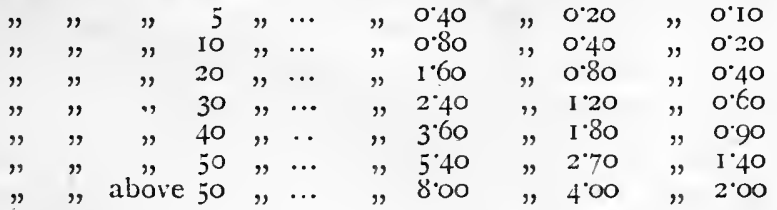

It will be seen that the tax was not imposed on tickets issued to passengers by the fourth class.

The effect of the tax has, admittedly, been disappointing from a revenue standpoint, inasmuch as persons who formerly travelled first class now often go second; the previous second class passengers go third class; and the fourth class has been swollen by persons who previously travelled third.

On May I, 1907, independently of the aforesaid Imperial tax, there came into operation a "reform" of the existing tariffs in regard both to passengers and to luggage. It is this "reform " which has been spoken of as having brought about substantial reductions in fares.

What it did was to abolish return tickets, and effect a reduction in the cost of single tickets.

The return tickets, however, had been issued at less than the cost of two single tickets, the sum total of which, notwithstanding the reduc- 
292 Railways and Nationalisation.

tions made, is, generally speaking, now higher than the previous charge for a return ticket. Although, therefore, a person making a single journey, or not returning by the same route, pays less than he did before, another person who does so return, but is no longer able to purchase a return ticket, pays more.

The effect of this new arrangement may be illustrated by the following figures, showing the past and present fares between London and Berlin viâ the Hook of Holland, for which international journey return tickets are still issued, as a matter of convenience, though at the total cost of two single fares :-.-

\section{Prior to Since}

ReducMay 1, 1907. May 1,1907 . Increase. tion.

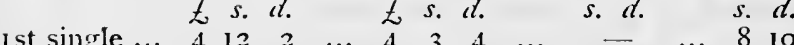
2nd single... $3 \begin{array}{lllllllllllll}3 & 3 & 3 & \ldots & 2 & 15 & 5 & \ldots & - & \ldots & 7 & 10\end{array}$ $\begin{array}{rrrrrrrrrrrrr}\text { Ist return } \ldots & 6 & 12 & 0 & \ldots & 7 & 4 & 3 & \ldots & 12 & 3 & \ldots & \ldots \\ \text { 2nd return } . . & 4 & 11 & 4 & \ldots & 4 & 13 & 0 & \ldots & 3 & 8 & \ldots & -\end{array}$

'The benefits of the "reform" system, therefore, exist in the case of one class of travellers only, and are non-existent in the case of those returning by the same route, the latter constituting a considerable proportion of the whole.

The "reform" system further abolished all free luggage. Passengers had previously been allowed to have $56 \mathrm{lbs}$. of luggage free. Under the new arrangements all luggage put in the van must be paid for. In this respect the Dutch railways have followed the example of the 
German railways, so that the traveller from (say) London to Berlin now has to pay (in addition to the increased charge for, a return ticket) five shillings in respect to the $56 \mathrm{lbs}$. of luggage which he was previously entitled to take free.

In Germany railway passengers seek to evade the new charge by reducing their luggage to such proportions that they can take it with them into the carriage. The result is that the compartments and corridors of the express trains, especially, get so blocked up with luggage that considerable inconvenience is caused.

Altogether, the changes have led to much adverse criticism in Germany, where they are widely regarded in the light of very doubtful advantages to the travelling public.

How disappointing the results have been to the Government has been shown by the Berlin correspondent of The Times, who, in an article on "German Imperial Finances," published in that journal on April 28, I908, said :-

The duty on passenger tickets continues to be a conspicuous failure, with a revenue of only f.930,000, as compared with an estimate of over Ei,500,000. 


\section{CHAPTER XII.}

\section{PURCHASE TERMS AND CONDITIONS.}

Presumarly, if the British "Government should decide to take over and "nationalise" the railways of the United Kingdom, they would be prepared to pay for them.

It is necessary to state this assumption, in considering the financial aspects of the proposal, because the fact cannot be denied (I) that the Socialists would prefer to adopt a policy of direct appropriation; and (2) that they have been distinctly encouraged in this idea by the "time limit" "theory which the present Government have developed in regard to the licensed tradé. Writing on the subject of the Licensing Bill in The Socialist Review for April, ic,o8, Mr. Philip Snowden, M.P., said:-

The other valuable feature of the time limit is that it establishes a precedent by which, without compensation by, or cost to, the community, a private monopoly may be transferred to the State. Public opinion approves the time limit as sufficient compensation to the owners and license holders of public-houses because their monopoly is one conferred upon them by the State, and because the traffic is one which ought not to be used to enrich individuals at the expense of the community. This precedent, furnished by non-Socialists, is one which will not be forgotten when public opinion regrets 
the anti-social privileges conferred by our forefathers and ourselves upon land monopolies, railway monopolies, mine royalty monopolies, and all other monopolies foolishly handed over to private individuals by the community.

Other Socialists have written or spoken to the same effect.

Then Mr. Asquith, in referring to the Licensing Bill in the course of his speech at Birmingham on June 19, I908, said :-

It represents the latest phase of the perpetual conflict which, generation after generation, the Liberal party has been waging to assert the paramount supremacy of public over private, and general over particular interests.

Mr. Asquith, it will be observed, said " latest " and not "last" phase; and the assertion as here proclaimed might certainly be made to apply to railway interests as freely as to the other interests in question. The principle would obviously be the same, and, as Mr. Snowden pertinently suggests, a precedent in regard to details has been already set up in the theory of a "time limit."

For the present, however, at least, one may look at the possibilities and prospects of railway nationalisation from the point of view of State purchase, rather than State confiscation; and it is desirable to consider the question as to what price would have to be paid, and the financial issues generally that purchase might involve, should such step be resolved upon. 
296 Railiways and Nationalisation.

\section{THE $A$ CT OF 1844 .}

The State has already had, since the passing of the Railways Regulation Act of 1844 , the right to acquire considerable portions of the railway system of the United Kingdom, that right having been secured under the following circumstances :-

In the year 1844 there was every indication that the railways would become a great financial success, and bring in very large returns indeed to the fortunate shareholders. The dividends then being paid on some of the lines were :-

London and South- IVestern $\tau_{4}^{\frac{1}{4}}$ per cent.

Great Western _.. ‥ $i^{\frac{1}{2}}$, , ,

Manchester and Leeds ... $7^{\frac{1}{2}},$, ,

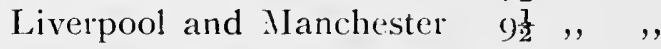

London and Birmingham 10 ," ,

Grand Junction _.. ‥ 10 ,, ,

York and North Mlidland ... Io ,, ,

To Sir Robert Peel's Government it not unnaturally appeared desirable, in these circumstances, that the State should reserve to itself the right to control a possibly excessive prosperity on the part of the railway companies, and take steps to protect the interests of the public at whose expense such prosperity might be gained. Ilence the Act of 1844 , which was based on the virtual admission and assumption that railway companies might reasonably be left to pay dividends of anything below io per cent., yet stipulaterl that when this amount was reached 
the Government had a right to intervene; and such intervention, it was laid down, might take one or other of two distinct forms.

In the first place, when a railway company paid a io per cent. dividend, or over, the Government might revise the company's rates, with the view, apparently, of bringing the earnings below the ro per cent. limit.

In the second place, there was to be the option of purchase, at any time after $2 \mathrm{I}$ years from the first of January, i 845 , in the case of any or all lines constructed subsequently to the passing of the Act; the terms laid down being twenty-five years' purchase of the annual divisible profits on the average of the three years next preceding the date of purchase.

Although, however, laying down these principles and "reserving" to the Government the power to enforce them, the Act expressly refrained from putting the powers in question into force at that time, clause + stating:-

Whereas it is expedient that the policy of revision or purchase should in no manner be prejudged by the provisions of this Act, but should remain for the future consideration of the Legislature upon grounds of general and national poliey .... be it enacted that no such notice as hereinbefore mentioned, whether of revision or purchase, shall be given until provision shall have been made by Parliament, by an Act or Acts to be passed in that behalf, for authorising the guarantee or the levy of the purchase money hercinbefore mentioned.

Since this $\Lambda$ ct was passed there have been 
many changes in the general position. The railway system has expanded substantially, and the traffic has greatly increased; but the growth in expenditure has far exceeded the growth in receipts, while Parliament has subjected the rates to repeated revisions without waiting for the dividends to attain the 1844 proportions of Io per cent. Thus the first option of the Act has already been carried out; but the second, that of purchase, still remains in abeyance.

We may fairly assume that one reason, at least, why these particular provisions of an Act passed over 60 years ago have not been taken advantage of is that the railway companies have not, on the whole, been remiss in their obligations towards the public.

Looking more closely into the terms of possible purchase, as thus laid down in 1844 ; it will be noticed that railways then already in existence were not included in the scope of the Act; and while it is true that the railway system was still in its infancy in 1844 , there had then already been constructed 2,320 miles of railway which constitute links of paramount importance in the great trunk lines of to-day. The complete list will be found in an extract from the Report of the Royal Commission on Railways, 1865, which I have given in an Appendix; and it will there be observed that the Commissioners remark, "This list includes (with the exception of the Great Northern Railway) the main lines of communication throughout England." Suf- 
fice it here to say that the lines already existing in i 844 included such sections as London to Birmingham, Birmingham to Manchester, and Manchester to Liverpool (London and NorthWestern Railway); London to Bristol (Great Western); London to Colchester (Great Eastern); Nine Elms to Southampton (London and South-Western); and Birmingham to Gloucester (Midland). Such indispensable parts of our railway system as these would not come within any power of purchase already provided for by the Legislature, and would have to be acquired independently of the terms specified by the Act of 1844 . One sees from this how impracticable it would be to attempt to make any forecast of what the Government would have to pay.

Then the fixing of the terms of purchase on the basis of twenty-five times the balance available for dividends, estimated on an average for the three previous years, would exclude stock on which no dividends at all have been paid during that period, although there may be reasonable hopes on such lines of dividends being eventually secured when traffic has increased owing to the development of residential districts, mineral resources, and so on. The Act does, however, provide that if a company shall be of opinion that twenty-five years' purchase of the annual profits "is an inadequate rate of purchase, reference being had to the prospects thereof," the amount to be paid shall be left to arbitration. Presumably, therefore, the pur- 
chase price of lines whose dividends are prospective only would be decided by arbitration; so that once more an element of uncertainty is introduced.

\section{A DOLBTFUL PRINCIPLE.}

Whether the price to be paid should still be fived on twenty-five years' purchase of the annuai divisible profits, or whether, under the altered conditions of to-day, some other term of years should be taken, are debateable details which I will not here stay to discuss. I would, however, raise the question whether the principle of basing the purchase price on annual divisible profits at all is, in itself really sound and one that should be accepted.

Let us assume, for the sake of argument, that there are two railway companies of which one ranks as "provident," and the other as more or less " improvident." The former does everything it can to maintain its lines in the best possible condition, and pays for everything it can out of revenue. The latter aims at giving as big a dividend as possible, is less careful in regard to maintenance, and depends too much on capital, in order not to diminish the available revenue. On the basis of the 1844 Act the improvident company would get terms much better, in proportion, than those secured by the provident company; while the Government would not get as good value when they paid more, in proportion, to the one company, as when they paid less, in proportion, to the other. 


\section{Purchase Terms and Condtions. 3ó}

If, again, it were tolerably certain that the Government would, in the course of a few years, acquire the lines on the basis of annual divisible profits, a direct incentive would be offered to the provident company to spend less on maintenance, and to effect an increase in the dividends which would decide the price to be paid. Savings on maintenance could be effected in such a way-as, for instance, in regard to the relaying of rails-that the results might not be noticed until some years after the Government had acquired possession.

Whether or not the provident company resisted the temptation to adopt such a course, it would be treated unfairly-as compared with the improvident company--under any hard and fast application of the purchase principle in question; and the placing of a premium on "annual divisible profits," to the discouragement of betterments paid out of revenue, would certainly not be to the advantage either of the Government, as purchasers, or of the community as users.

THE TELEGRAPH ACT, 1868.

Incidentally, and leaving aside for a moment the Act of 1844 , it might be mentioned that under the provisions of the Telegraph Act, i868, the terms of purchase of the United Kingdom Telegraph Company were 20 years' purchase of the net profits; an extra sum for certain defined patent rights; a sum equal to the estimated: 
aggregate value of the quoted ordinary share capita! of the company; and compensation for loss of prospective profits. Apply such terms to the railways, and the purchase price would probably far exceed the present capital value.

\section{CAPITAL AND SHAREHOLDERS.}

Whatever price the Government did have to pay, and whatever financial arrangement as to the issue of railway bonds or otherwise they might think it best to make, the sum involved would be of enormous magnitude, and the prospect of their making a good bargain for the State altogether problematical.

According to the Board of Trade "Railway Returns," the total amount of railway capital returned as raised at the close of 1906 was nearly

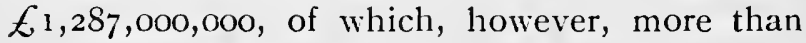
E195,000,000, or i5 per cent., was due to nominal additions on the consolidation, conversion and division of stock.

The assumption so widely entertained that, even allowing for " watered capital," the vast sum which here comes into question represents money put into British railways by "capitalists," leaves out of account the fact that a very large proportion indeed of the railway proprietors have only small or comparativèly small hold. ings. What these may be is shown by the following table, which I reproduce from the Great Western Railway Magazine for July 1907 :- - 


\begin{tabular}{|c|c|c|c|c|c|}
\hline Con & npany. & & $\begin{array}{c}\text { Number of } \\
\text { Shareholders, } \\
\text { exclusive of } \\
\text { Debenture } \\
\text { Holders. }\end{array}$ & $\begin{array}{l}\text { Holdings } \\
\text { of } £_{500} \text { and } \\
\text { under. }\end{array}$ & $\begin{array}{l}\text { Percent- } \\
\text { age of } \\
\text { Holdings } \\
\text { of } £, 500 \\
\text { and under. }\end{array}$ \\
\hline Belfast and Cou & inty Down & $\cdots$ & 1,663 & 1,176 & $\begin{array}{c}\text { Per cent. } \\
70\end{array}$ \\
\hline Brecon and Mer & rthyr $\quad \ldots$ & $\cdots$ & 770 & 565 & 73 \\
\hline Caledonian & $\ldots$ & .. & 37.640 & I $8,25 \mathrm{I}$ & 48 \\
\hline Cambrian... & $\ldots$ & $\ldots$ & 1,250 & 801 & 64 \\
\hline Central London & & $\ldots$ & 2,739 & 2,108 & 77 \\
\hline City and South & London... & ... & 2,300 & I, 538 & 66 \\
\hline Cork, Bandon a & ind South-Coas & & I, 431 & 1,086 & 75 \\
\hline Colne Valley & $\ldots$ & $\cdots$ & 320 & 289 & 90 \\
\hline East and West & Junction & $\cdots$ & 94 & 72 & 76 \\
\hline Furness $\quad .$. & $\cdots \quad \cdots$ & $\cdots$ & 5,355 & 3 , I I I & $5^{8}$ \\
\hline Glasgow and So & outh Western & $\cdots$ & I I, 520 & 5,776 & 50 \\
\hline Great Central & $\cdots \quad \ldots$ & $\cdots$ & $20,3^{88}$ & 10,723 & 52 \\
\hline Great Eastern & $\ldots$ & $\ldots$ & 27,835 & 12,617 & 45 \\
\hline Great Northern & $\ldots ; \quad \ldots$ & $\ldots$ & 29,446 & $13,35^{\circ}$ & 45 \\
\hline Great Northern & (Ireland) & $\cdots$ & 8,406 & 5,323 & 63 \\
\hline Great North of & Scotland & ... & 4,950 & 2,778 & 56 \\
\hline Great Southern & and Western & $\ldots$ & $11,4^{8} 3$ & 7,205 & 62 \\
\hline Great Western & $\ldots \quad .$. & ... & 62, I 55 & 32,671 & 52 \\
\hline Highland ... & $\ldots$ & ... & 5,640 & 3,971 & 70 \\
\hline Hull and Barnsl & ley & $\cdots$ & 6,228 & 5,041 & 80 \\
\hline Isle of Man & & ... & 566 & 480 & 84 \\
\hline Lancashire and & Yorkshire & $\ldots$ & 27,100 & I I, 857 & 43 \\
\hline Londion and $\mathrm{Nc}$ & crth Western & ... & 53,963 & 23,536 & 43 \\
\hline London and Sor & uth Western & ... & 24,142 & 10,992 & 45 \\
\hline London, Bright & ton \& South Co & oast & 19,965 & 12,587 & 63 \\
\hline London, Tilbur & ry and Southen & ad. & 3,250 & 1,700 & $5^{2}$ \\
\hline Metropolitan & $\cdots$ & $\ldots$ & 9,435 & 4,265 & 45 \\
\hline Metropolitan D & istrict & ... & 886 & 337 & $3^{8}$ \\
\hline Midland ... & $\cdots, \quad \ldots$ & $\ldots$ & *80, o10 & 26,040 & 32 \\
\hline Midland and & South West & tern & & & \\
\hline Junction & ․ $\quad \cdots$ & $\cdots$ & I,449 & I, 222 & 84 \\
\hline Midland (Great & Western) Irel & and & 5,980 & 3,980 & 66 \\
\hline North Staffordsl & hire $\quad .$. & $\cdots$ & $5,8 \mathrm{co}$ & 2,770 & 47 \\
\hline Northampton ar & ind Banbury & $\cdots$ & 69 & 43 & 62 \\
\hline North Brilish & $\cdots \quad \cdots$ & $\cdots$ & 32,746 & I 6,973 & 71 \\
\hline North Eastern & $\cdots$ & ... & 42,514 & 22,294 & 52 \\
\hline North London & $\cdots$ & * & 1,726 & 839 & 48 \\
\hline Rhymney... & $\cdots$ & $\cdots$ & 2,100 & 1,096 & 52 \\
\hline South Eastern & $\cdots$ & $\ldots$ & 14,423 & $8,48 I$ & 58 \\
\hline Taff Vale ... & $\cdots$ & ... & 6,683 & 5,129 & 76 \\
\hline
\end{tabular}

* The ordinary stock has been split. 
304 Rallways and Nationalisation.

This table is certainly open to the criticism that many of the investors would have stock in several companies. On the other hand it is no less true that many of them, especially among the larger holders, represent banks, insurance companies, thrift organisations, labour unions, etc., each having a more or less considerable number of individuals-in some cases, many thousands-interested in the security of the investments.

\section{DIVIDENDS.}

'The average dividends paid on the various classes of capital in 1906 were, approximately, $3 \frac{1}{4}$ per cent. on the ordinary capital, $3 \frac{1}{2}$ per cent. on the preference, 4 per cent. on the guaranteed and $3 \frac{1}{2}$ per cent. on the loans and debenture stock; though it is pointed out by the Board of "Trade that "these rates are naturally lower than they would have been had there been no nominal additions to the capital of the companies. The average rate of dividend or interest computed on the total capital, as it would have stood if no nominal additions had been made thereto, was 408 per cent."

The rates of dividend or interest paid on each description of capital in 1906 were as follows :- 
Purchase Terms and Conditions. 305

\begin{tabular}{|c|c|c|c|}
\hline \multirow{2}{*}{ 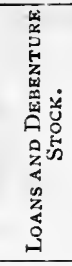 } & مَّ & mo & $\stackrel{0}{8}$ \\
\hline & 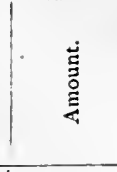 & 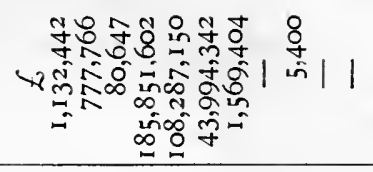 & 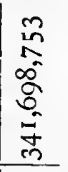 \\
\hline \multirow{2}{*}{ 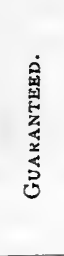 } & 总苞造 & 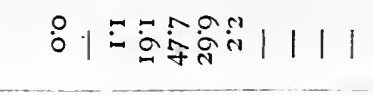 & 0 \\
\hline & $\stackrel{\stackrel{\rightleftarrows}{ت}}{\stackrel{\Xi}{\Xi}}$ & 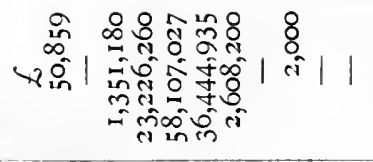 & 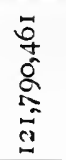 \\
\hline \multirow{2}{*}{ 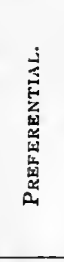 } & 岕总递 & 垈 & 8 \\
\hline & 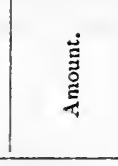 & 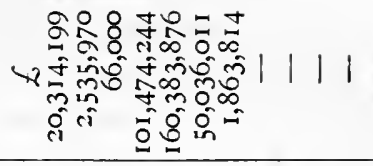 & 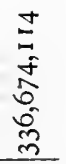 \\
\hline \multirow[b]{2}{*}{ 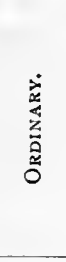 } & 苍苛 & 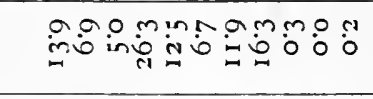 & 0 \\
\hline & 岁 & 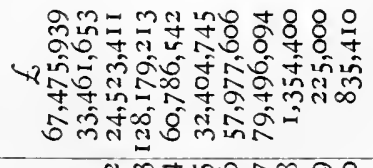 & 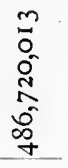 \\
\hline \multicolumn{2}{|r|}{ 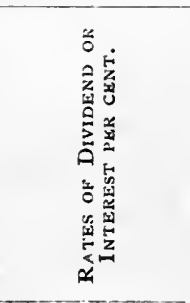 } & 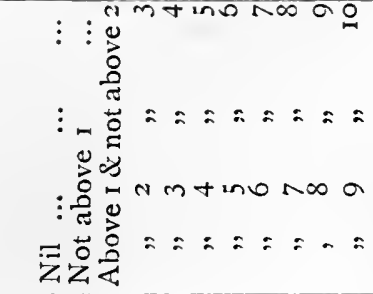 & $\frac{\vdots}{\stackrel{5}{0}}$ \\
\hline
\end{tabular}


This table shows how little the expectation entertained in 1844 , that ro per cent. was likely to become the normal rate of dividend for British railway companies, has been realised. It shows that if the Government had bought up the railways at the prices of (say) ro years ago they would be regretting a bad investment to-day. It shows, also, that even if they took over the whole of the lines at the present low prices, they would have to acquire a very large amount of stock on which there is no yield at all, while there is much that does not return sufficient to cover the interest they would have to pay on the railway debt. In other words, they would assume those burdens of over-capitalisation and unproductive investment which now handicap some of the companies so severely in their desire to effect progress and reform.

The State would thus perpetuate some of the greatest disadvantages of the present railway position, if it did not actually increase them, inasmuch as those in restors who are sufferers from this position would be much less tolerant if they had to deal with the State than they are in the case of a company doing the best it can to meet adverse circumstances. The State would also concentrate in a single unified system a dead weight of unproductive capital now distributed among a number of companies; though, considering that such unproductiveness is due in no small degree to the policy adopted by successive 
Governments towards railway companies in the past, the falling of some of the burdens in question upon the shoulders, as it were, of the State would be only in accord with the dictates of poetic justice.

\section{THE OUTLOOK FOR THE STATF.}

In the result, and bearing always in mind that the present average yield from the 1ailways is less than $3 \frac{1}{2}$ per cent., it is probable that the utmost the Government could hope $t()$ do, as the result of adopting a nationalisation policy, would be to pay interest on the railway debt it would create. Instead of the railway revenue being available, as some enthusiests assume, for "reduction of taxation," or other such purposes, it might be practically absorbed in meeting merely a new set of obligations. The railway shareholder would disappear, but the holder of Government stock would take his place-with this difference: that if the earnings fall off, the shareholder now has to go without his dividend, whereas the holder of Government stock would still expect the State to pay him his interest.

EXTENSIONS AND BETTERMENT.

The considerations thus far advanced relate to purchase only. One must remember, however, that, as the Japanese Government are finding, the nationalisation of the railway system of a 
country involves not alone heavy financial obligations for the acquirement of existing lines, but the raising of further considerable sums to defray the cost of extensions and betterment. In our own case, for example, assuming that the Government took over the railways on terms just and reasonable to the present proprietors, what would be their attitude towards that question of converting steam traction into electric which, in the view of some experts, is becoming one of the great problems of the near future? 'Would the Government, after burdening themselves with a great financial responsibility, and especially with a large amount of un remunerative stock, launch readily into the very heavy expenditure necessary for such a transformation in transport as this? If they were ready so to do, what would be their position in raising fresh loans to provide for the capital outlay-exceptionally large in their case, because they would have to do work which, in existing conditions, would be undertaken by a number of individual companies? How would the Chancellor of the Exchequer be likely to regard such large capital expenditure on the railways when their accounts became part and-parcel of the ordinary finances of the country?

Even leaving aside the question of electric traction, it is the poorest lines, from which little or no return is obtained, on which, were the entire system nationalised, the Government would need to spend, relatively, the largest 
amount of money. Local residents and traders who are ready to make allowances now would cease to do so when the lines were State-owned and the bottomless purse of the British taxpayer became available for their improvement.

\section{SUBSIDIARY UNDERTAKINGS.}

A further group of considerations would arise in connection with those many subsidiary enterprises which have become associated with the ownership and operation of railways in the United Kingdom to an extent unknown in any other country-a fact which, in itself, makes any possible policy of nationalisation here much more intricate in its details than was the case, say, when Prince Bismarck planned his purchase of the Prussian lines. He made that purchase at a much lower price than would have had to be paid to-day; he extended his scheme over a series of years; and he had few or no "side-shows" to deal with. British railway nationalisers would buy to-day under unfavourable conditions; they want to acquire the entire system at once; and there are many things besides railways and rolling stock that must be taken into account in the matter of terms.

One may assume that the State, in acquiring the railways here, would be obliged to deal with the subsidiary railway interests as a material part of the railway system. The adoption, however, of this reasonable, if not inevitable, course 
would not only affect the basis of purchase, as defined by the Act of IS.44 (since most of the "side-shows" in question have come into existence since that Act was passed), but would raise the problem as to what the State should do with the enterprises in question when it had them ; while, if the Government of the day decided to carry them on, they would find themselves directly competing with a wide range of private interests. There might thus arise serious questions not alone of finance and of national policy, but even of possible international complications.

\section{STEAMSHIPS.}

At the present time, for instance, various British railway companies control lines of steamers performing regular and competing services between England and Continental ports. The Great Eastern Company has the Harwich route to the Hook of Holland and Antwerp; the Great Central Company has steamers between Grimsby and Rotterdam, Antwerp and Hamburg; and the Lancashire and Yorkshire operates between Hull and Zeebrugge (Belgium). Then the Dutch Government are interested in the Flushing route, served by the State lines in Holland, while the Belgian Government own and operate the Ostend-Dover route, worked in conjunction with the Belgian State lines. If the British Government took over all the railways 


\section{Purchase Terms and Conditions. 311}

here, would they continue, and themselves operate, the English steamship lines mentioned, or would they, in the interests of economy, stop the competition and keep, say, to only one of the routes? Alternatively, if they maintained them all, as at present, would the Government operate them as effectively as the different railway companies are doing?

Still further, whether the Government maintained all the English-owned steamship lines or reduced their number, what would be their attitude towards the Flushing and the Ostend routes? Would they, as owners of (say) the Harwich route, still afford every possible facility to these foreign-owned routes to compete successfully with themselves? If they did not do so-to their own pecuniary disadvantagemight there not be the possibility of diplomatic controversies of a kind which can be far more successfully avoided when the steamshipowners on this side, at least, are commercial companies?

Nor must we overlook the steamship lines to France and to Ireland which are controlled by competing English railway companies. Would the State continue all these as well? In the case of Ireland, a prodigious sum of money has been spent on the Fishguard route, the advanlages of which, especially for residents in the South and West of England, have been greatly appreciated. In all probability, however, if the 
State had acquired all the British railways io years ago, this Fishguard route would, on the abolition of rail competition, never have been created. With a monopoly of all the railways, the interest of the Government in creating new steamship services, however necessary or desirable, would have been nil. The results might have made for economy, but they would certainly have checked a development of the facilities for travel.

In addition to the steamships owned by the railway companies there are the coasting vessels which compete severely with the railways and are responsible for many of the "anomalies" in railway rates. Would the Government buy up the coasting steamers, or would they still try to compete with them, as the railway companies have done? If they did neither, and sought instead to abolish the anomalies by not giving lower railway rates on traffic between ports than for equal distances inland, they would see the coasting steamers profit still more at the expense of the railways.

DOCKS.

In the matter of docks, we have to bear in mind the very substantial interests of the Great Central Railway Company at Grimsby; of the London and South-Western Railway Company at Southampton; the Great Western Railway at Plymouth; the Taff Vale Railway Company at 
Purchase Terms and Conditions. 313

Penarth Dock (Port of Cardiff); the Barry Railway Company at Barry (Glamorganshire); the London and North-Western at Garston; the Midland Railway Company at Heysham, and so on. IVould the Government, in acquiring the railways, take over these docks and operate them in competition with docks elsewhere owned or operated by private companies or by municipalities? If it transferred them to independent companies there would still be the question as to the relation of the railway lines to docks which would retain their own competing interests, especially in regard to the Atlantic trade.

\section{RAILWAY HOTELS.}

Control of the railway hotels, which form part of the British railway companies' organisations, would; at least, afford the Government the opportunity of giving the world an object lesson as to the way in which licensed houses should be conducted; though, perhaps, after having acquired the licences - of course, at their "monopoly value "- they would say that the railway hotels were "redundant" and abolish them accordingly.

\section{RAILWAY ENGINEERING WORKS.}

Still further, in the "forties" the railways did not manufacture their own engines and rolling stock, nor were there in existence signal and electrical works, and various developments in connection with the engineering department. It 
314 Railways and Nationalisation.

cannot be supposed that this property could be acquired on the terms set out for railways alone, and big sums would have to be allowed for such huge railway engineering establishments as those at Crewe, Swindon and elsewhere.

\section{CANALS.}

What would the Government do with the canals owned by the railway companies, and necessarily to be taken into consideration among the railway properties? If they bought and decided to continue the railway-owned canals, would they also buy up the canals owned by independent companies?

There has been much talk of late about the canals being nationalised and improved, if not reconstructed, at a very substantial cost, to enable them to compete better with the railways, or at least-and, perlaps, more especially-to coerce the railway companies into lowering their rates. Would, however, the State, as an owner of now more or less obsolete canals, be willing to spend a large sum thereon in order mainly to compete with itself as an owner of railways?

\section{RAILWAYS OR TRAMWAYS?}

Ilow, again, would the State, as an owner of railways, act towards the municipalities as owners of electric tramways? The latter, as cveryone knows, have become formidable competitors of the railways for the transport of 
suburban residents, and there are lines of railways where the receipts have recently undergone a very substantial reduction in consequence. With costs of construction, standing charges and working expenses all much heavier, a railway cannot compete for short-journey traffic with municipal tramways more or less rate-aided or rate-guaranteed; and hitherto the railway companies have had to see a great deal of traffic taken from them by their more favoured competitors, whom, through the local rates, they may have helped to establish. Would a Railway Minister, with zeal stimulated by the Chancellor of the Exchequer, regard such rivals complacently, and, as a member of the Government, allow the municipalities to reduce State railway earnings to a still lower point?

\section{TIIE EFFECT ON AUTOMOBILISM.}

There is yet another interest which comes into consideration. I read in the issue of The Car for February 19, 1908:-

There are, no doubt, many who advocate the State ownership of railways from a Socialist point of view, but it solely concerns in The Car not what the political effect might be, but what would likely to be the effect on automobilism. First of all, if the State were to own the railways, it would naturally be jealous of all other means of conveyance and locomotion. There would be continual pressure put upon Parliament to make the use of motor-cars and motorlorries as unprofitable as possible, lest they should injure the receipts of the railways. Any such 
schemes as motor-roads or the improvement of exits from towns would be considered largely in a competitive sense, for the Government would be bound to see that their railway system paid as well as possible, and all competition, therefore, would be barred by every means in their power. It would, of course, be to their interest that roads should not be improved, so that travelling should be confined as much as possible to the State railways. 'There are States to-day in which the development of State-owned railways is having this very effect. Secondly, the taxpayer would also be appealed to by both parties to avoid anything which might increase taxation, and voters would be tempted to discourage any form of locomotion which would compete against railway travelling, in whose profits they would share. Also comfort, speed, and cheapness would be matters which would not troub?e a Government department once competition was eliminated. Therefore I maintain that were the Government to take over the railways of this country there would be distinct hostility between automobilism and the policy which would have to be pursued by the Chancellor of the Exchequer, and motoring and its interests would naturally go to the wall.

There could hardly be a question here of State purchase. But there would be the possibility of still another conflict between State and private interests.

\section{OPPORTUNITIES FOR GRIEVANCES.}

It is reasonable to assume that if the railways were nationalised the supreme control of the system---with such subsidiary undertakings and interests as might be continued in association therewith-would be entrusted to a Railway 
Minister at the head of a State Railway Department. It can hardly be supposed that everything would simply be given over to the Board of Trade-already overburdened with duties of many kinds. But the main responsibility would still rest with the Government, and the paramount authority with Parliament; and one can imagine to what interminable questionings, debates, and ventilations of grievances great or small the administration of so complicated an undertaking would give rise.

The well-honoured custom of sending railway grumbles to The Times would die out. In future every grumbler would want " his" member to "bring the matter " before " the House" ; and the already limited time available there for dealing with great public questions would become still less when Ministers had to deal with swarms of questions and controversies arising out of the real or fancied grievances of workers, travellers, traders, or persons concerned in the great variety of enterprises included in the operation of a State railway offering, in the circumstances, exceptional scope for complications and criticisms. 


\section{CHAPTER XIII.}

\section{THE QUESTION OF SAVINGS.}

THE one comforting conviction to which the nationalisation party pin their faith on matters of finance is that State operation of a unified system of railways would effect such great econoinies that not only need there be no uneasiness as regards results, but large savings may be anticipated as well. When they come to details concernings these economies and savings, the adherents of the said party invariably start off with the boards of directors. Elaborate details are given as to the total number of boards, the number of members on each board, the age of each member, the fees that are paid, and so on. After this it is customary to make comparisons with Prussian State railway conditions - to the disadvantage of our own. 'Thus Mr. A Emil Davies says in his book on "The Nationalisation of Railways" :-

If it be: urged that these directors are really required, how is it that the Prussian State railways ace worked without a single railway directo:?

Other writers have represented that in Prussia the entire State railway system is directed by a 
single Minister, who takes the place of all the railway directors to be found here. Therefore, they say, have State railways, save directors' fees, and you may expect to live happy ever after.

The fact should be borne in mind that, under the system in vogue here, directors are appointed by the shareholders to watch over the financial interests of property belonging to them in common, and to control matters of general policy rather than take an active part in the actual details of working management, which are left, rather, to expert railway officers. If the shareholders who vote them their fees considered the directors were not wanted, or were not earning those fees, they could decline to elect them, reduce them in number, or allot them less remuneration. Shareholders are not generally given to wasting their money when they have the remedy in their own hands.

As for the qualifications and age of directors, it is certainly the case that, as a rule-and allowing for certain exceptions-railway directors are taken from the same classes as those from which members of the Government are chosen; while, considering the value to be attached to judgment and experience, as distinct from physical energy, there is no more reason for setting up an age limit in the case of railway directors than there is in that of Cabinet Ministers. Such an age limit is rightly imposed on railway officers, 
whose laborious daily toil may involve a considerable strain on their physical or mental powers; but the position is different in the case of directors, whose function is mainly a controlling and advisory one.

\section{THE SYSTEM IN PRUSSIA.}

Whether British railway directors earn their modest fees or not, and whether or not they should be put on the same level as the unfortunate City clerk who is "too old at forty," the fact remains that they would no longer be wanted, and their fees would, indeed, be saved, if the State bought up all the lines. But would there really be any financial gain thereby?

If we look to Prussia for evidence on which to base an answer to this question, we shall find that the position in that country is not exactly what has been represented.

The suggestion that the Railway Minister there does the work of all the directors of all the railway boards in the United Kingdom is highly complimentary to that gentleman, but is not really warranted by the facts. It is true that in Prussia the Minister of Public Works stands at the head of the State railway system, with its $2 \mathrm{I}$, 000 miles of lines. But the responsibility for the operation of the system, together with the fixing and adjusting of fares, rates and charges, and the deciding of administrative questions in general, is dirided among no fewer 
than twenty-one "Royal Railway Directories" - each, in effect, a board of directors having control over all working details within its particular division. Each directory, again, has its central office, with clerks, treasurers, book-keepers, etc., and each is at the head of an elaborate organisation, comprising advisory council, departments, sub-departments, special offices, and so on.

I am far from saying that our own conditions are perfect and incapable of improvement; but it seems to me that if we eliminated the boards of railway directors in the United Kingdom and set up, instead, in England and Wales, Scotland and Ireland, twenty-one separate and distinct State departments, each operating in an assigned territory, with an independent staff and all the routine and red-tape which State administration involves, there would not be much left out of the saving on the fees to directors for a general increase of railway men's wages, or a general lowering of rates and fares, to say nothing of a contribution towards old-age pensions or a decrease of the income-tax.

THE RAILWAY CLEARING HOUSE.

A strong point is also made by the nationalisers of the saving that would be brought about through the abolition of the Railway Clearing House, with, not alone its large force of clerks, but, also, the small army of men whose business it is to check the 
numbers of wagons and tarpaulins, so that, if a wagon-load of commodities should go from Brighton to Wick, not only will all the movements of that particular wagon be known, but the Clearing House clerks will have the data on which to decide what proportion of the rate paid shall go to each company over whose lines the wagon and the tarpaulin in question have passed.

I make no attempt to say how many men are thus engaged on Clearing House work outside the Clearing House itself. But it has still to be proved that, even by throwing the whole of these people on the unemployed list, and adding together alike their wages and the directors' fees, the increased expenditure in other ways, following on a resort to State purchase and State operation, would not more than counterbalance the sum total thus saved.

\section{OTHER ECONOMIES.}

There would be savings, again, in ( $I$ ) the running of fewer train services: (2) having fewer receiving offices; (3) better loading; (4) in the fact of locomotives, carriages and goods wagons being joint stock, available for general use, instead of having to be returned to a particular company's system. The first of these savings would be subject to complaints from the public as to decreased facilities; but in point of fact all four can be effected, in part, at least, by 
combinations or working agreements among the companies themselves, without (as I shall show in Chapter XVI.) any resort to the dubious experiment of State purchase and State operation.*

It is further argued that under nationalisation the considerable sums of money spent by competing or enterprising companies on advertising would be saved. But one may assume that the companies incur this expenditure because they find that advertising pays, by bringing to their lines traffic they might not otherwise get. If companies run excursion trains or offer special facilities to tourists, they must let the public know what they are doing, and this can only be done by advertising.

The other expedient would be not to run excursions, not to offer facilities to tourists, and thus save on advertising, leaving people to travel by ordinary trains at ordinary fares, with the result that the public would not be so well served, and the traffic receipts would decrease. Such a policy is so far suggestive of "penny wise and

* Incidentally I would suggest, in reference to the receiving offices, that when the railways became State property the British public might expect to see such offices set up in even greater number in town and country, on a basis akin to that of the Post Office, in order to suit their personal convenience. On the other hand there has been in operation in London for some years, at the corner of the Strand and Norfolk Street, a joint receiving office for the London and North-Western, the Midland and the Great Northern Companies. 


\section{Raillways and Nationalisation.}

pound foolish," that even the Italian State railways administration are discarding it in favour of a very considerable increase in their advertising.

\section{PER CONTRA : WAGES.}

I have here made fair allowance, I think, for the various economies which nationalisation might effect; but, looking still at the matterfor present purposes-as a purely business proposition, apart from all questions of politics and policy, there are some per contra items which cannot be left out of the reckoning.

Of the cost generally of setting up a State system of control, on the lines of the Prussian system, I have already spoken. But there are other considerations, besides, and especially those relating to wages and clerkage.

The possibilities of securing higher pay and fewer hours of labour constitute the main reason why certain sections of railwaymen and their sympathisers are now favouring nationalisation, and the full force of their political influence and of their own and of kindred industrial organisations would be brought to bear on the realisation of this aim immediately the railways were acquired by the State. A leaflet recently issued by the Labour Party (which claims to speak on behalf of a million workers) declares that "the prosperity of a State is 
bound up in its workmen," that the railway men are notoriously underpaid and over." worked" and their work "too dangerous," and adds, "If the railways were the property of the State this would be altered, and altered quickly."

Even if an "all grades movement" were not actually started, there would still be the question as to how the Government would treat the clerks and the ordinary staff of workers employed on the less flourishing lines. These individuals at present have to be content with lower rates of remuneration than are given on more prosperous railways, such as the London and North Western, the Great Western and the Midland, because they know that their own companies cannot afford to pay them more. But would they be equally content when the lines in question were controlled by the Government, who could not make the same excuse? Whatever policy the railway workers as a whole might adopt, would not those on the poorer lines of today demand that the Government should at least level them up to the position occupied by others in the same district also employed by the State? Would there not be scope even here for bringing much political pressure to bear on the Government, and would not concessions even to this limited extent make a considerable addition to the working expenses, as against the savings in other directions? 
MAINTENANCE.

A minor question, though one not to be ignored, is whether or not a Government Department, having charge of the whole of the railways, would want, or would be expected, to standardise the maintenance, so as to have general principles applying to the entire railway system, as in the case of the Post Office, the Army and the Navy. At present there are great variations in regard to permanent way, railway stations, rolling stock, etc., according to the financial means of the companies, different ideas on the part of engineers or directors, nature of the traffic in particular districts, and so on. One may assume there would be no idea of re-laying branch lines with the heaviest types of rail simply because these were used for the main lines. But, apart from such extreme standardisation as this, there would be a good deal of "levelling up" called for in regard to the railways themselves, when they became a State system, just the same as there would be in respect to the pay of the railway workers.

\section{DIMINISHED GROSS RECEIPTS.}

Concurrently with the increase in working expenses in these and other directions, there would be a decline in the gross receipts.

Comparing Government Departments and private-enterprise organisations in general, it 
cannot be denied that the average person engaged in the latter has far more initiative, zeal, enterprise, and ambition in the performance of his duties than one finds in the average State servant. The former takes a personal interest in the prosperity of the concern with which he is connected, he feels pride in its success, and he does all he can to promote that success, if only because he knows that on the results he can show to his superior officer may depend his chances of promotion, chances which seem all the greater when he remembers that many of the general managers have risen from the ranks. So he will go out of his way to "oblige" the public, especially if, by so doing, he can earn a little more for the company; he does over-work or Sunday labour cheerfully when the need arises; and he develops unforeseen powers of eloquence when he sees a chance of getting some extra traffic for the line which he regards as "his."

In the case of a State Department the personal equation is very different. The State servant, with fixed hours, fixed salary, fixed prospects, routine duties, and no special incentives to exceptional energy on his own account or to considerateness towards others, may be a faithful enough strvant, but he regards his position and the service itself from a wholly different standpoint; he gets into a groove, and he is distinctly apt to make the public in general feel that he, 
as a representative of the State, cannot be expected to exert himself specially in the interests of those whom he seems to treat almost as his inferiors.

Possibilities such as these offer strong reasons against a transfer of the railways to the State, and they also suggest that, should such transfer take place, the lines will do less business, with a corresponding decline in gross receipts. Further, whether the State railways administration stopped the advertising or not, they would doubtless please the nationalisers by discontinuing the large staffs of canvassers and others who at present show unremitting zeal in working up or securing traffic for their companies. Here would be another saving in salaries, but here would be another cause of decline in traffic and traffic receipts, because much that is done by these "industrial commissioners," as they might be called, consists, not merely in the diversion of business from one company's lines to another, but in the creation of new business based on the facilities offered alike by their companies and by the districts they serve. If you stop the whole of this machinery, and substitute for it a rigid system of State control, operated by State officials disposed to leave the traders always to come to them, the result must be to check alike industrial expansion and the railway receipts, although estimates as to cost and results of State purchase are invariably based on 
the assumption that the traffic will continue as at present.

In connection with the possible decline in gross receipts, there is the further consideration that the railway companies now get a certain revenue from the Government for the conveyance of mails, troops, etc. Would these be carried free when the railways were nationalised? The State would not, perhaps, want to take money from one pocket to put into another, but the loss of the revenue from these sources would affect the railway receipts. The State railways might save if they were not required to pay into the Treasury the sums now received from the railways for income tax and passenger duty, but the Treasury would lose in proportion; and though the State, as an owner of railways, might refuse to be exploited by the local authorities in the matter of local taxation (as the railway companies are at present) the burden from which the lines would thus be relieved-to their advantage -would, probably, only fall on the shoulders of the ordinary ratepayers.

Looking at the matter from no higher standpoint than that of a purely business deal, and bearing in mind, on the one hand, the magnitude of the sum that must be paid, not alone for the railways, but, as $I$ have shown, for their many subsidiary enterprises as well; and, on the other, the increased expenditure and the decreased receipts which would have to be set against the 
330 Railways and Nationalisation.

possible economies, the British taxpayer at whose risk the purchase would be made should indeed ponder well before he gives his assent to so huge a gamble. 


\section{CHAPTER XIV.}

\section{THE IRISH RAILWAYS.}

" Perhaps," said the Globe of May 9, 1908, in referring to a communication received from a correspondent who, while opposed to railway nationalisation in Great Britain, thought there was something to be said for nationalisation of the Irish lines, "Mr. Lloyd-George may feel tempted to move the Ministry to make an experiment in this direction, before plunging into the vastly different and more complicated question of English nationalisation." It has indeed, been suggested in various directions that this should be done, and proposals on the subject have been brought forward by a number of witnesses examined before the Vice-Regal Commission on Irish Railways, though other witnesses have strongly dissented. In the circumstances, therefore, it may be of interest if I give here a brief survey of the position in Ireland.

\section{FACTORS IN THE SITUATION.}

Comparisons of Irish conditions-whether in the matter of railway rates or otherwise-with conditions existing in countries on the Continent of Europe have been attempted by many critics of the Irish railways; but they must needs 
be delusive and unsatisfactory. In my own opinion Ireland, in regard to matters of transport, must be judged from her own standpoint rather than from that of other lands. By reason of her geographical position, Ireland can have no such transit traffic as that which adds so much to the prosperity of Belgium and Holland. She has not even the same chance as England has had to become a central mart for the reception and redistribution of the world's commerce. She is simply a starting point or a terminus for traffic which she either originates or else receives to supply her own needs. For Ireland to be in a position similar to that of Belgium or Holland--so far as geography would allow - it would be necessary that American commerce for England and the Continent of Europe should be landed at (say) Cork, and taken on to Dublin or Belfast for reshipment, the railways thus having a chance of handling transit as well as domestic, export and import freight.

Of great industries in Ireland, employing a large number of persons, there are (apart from agriculture) only three-the linen industry in north-east Ulster, ship-building in Belfast, and Messrs. Guinness's Brewery in Dublin. The production of minerals, again, is very small. A large proportion of the surface of the country consists of bog or barren land; no less an area than $3,600,000$ acres, or one-sixth of the total, has been scheduled under the designation of 
" congested districts" whose inhabitants-oneseventh or one-eighth of the total population of the country-are thus certified to be in need of public aid. The decrease in the population itself is continuous.

In all these respects, therefore, Ireland differs essentially from Continental countries, and she so far differs from Great Britain that, whereas there has never been any question of State aid being given to railways in England and Scotland, the Sister Isle has been regarded ever since the earliest days of railway history as requiring exceptional treatment.

STATE LOANS.

A Royal Commission appointed in 1836 to consider what steps should be taken to provide Ireland with railways recommended that-in the assumed unwillingness of private capitalists to come forward-the Government should themselves construct certain main lines, and a scheme to this effect was drawn up by the Government, and approved by Parliament. It fell through, however, and railway construction in Ireland was left to private companies as in England and Scotland, but with this difference-that the Government of those days advanced substantial loans out of the Consolidated Fund to the Irisin companies to assist them in raising the capital they required, such loans being repaid as the 


\section{Railinays and Nationalisation.}

finances of the companies permitted. By 1865 the sum total of the advances thus made was $\mathcal{E}_{2}, 364,000$, of which $\mathcal{E}_{1,209,000}$ had then been refunded.

BARONIAL GUARANTEES.

There was also introduced by the Tramways Act of I 860 a system under which guarantees of the payment of interest on capital expenditure on tramways or railways authorised by the Lord Lieutenant were made by the "baronies " passed through. These "baronies," I might explair. for the benefit of those unfamiliar with the term. constitute the largest sub-divisions of counties in Ireland. Prior to the Local Government Act of I 898 and the creation of County Councils, the affairs of the baronies were administered by grand juries, who, in addition to their judicial duties at Assizes, undertook the ordinary county business and assumed financial responsibilities on the credit of the rates.

In 1883 the Tramway and Public Companies Act (Ireland) supplemented the baronial guarantee of interest on capital required in the construction of tramways (in which were included light railways) by a recoupment from the State of one-half the amount paid by the locality in interest not exceeding 2 per cent. per annum. Schemes under this Act had to be approved by the grand juries of the districts concerned, but one of various objections raised against the Act 
was that it "favoured the creation of small companies, the management of which was not likely to be as efficient as that of larger companies able to command a more highly qualified staff." Nor did the Act serve the poorer districts it was specially desired to reach.

\section{STATE GRANTS.}

A further development followed in 1889, when the Light Railways (lreland) Act-known as Mr. Balfour's Act-introduced the principle of free grants by the Government for light railways either to be constructed by railway companies already having lines open for traffic, or to be taken over by such companies and managed and maiutained by them, when constructed. An essential preliminary, however, was a declaration by the Lord Lieutenant that such light railways were desirable, and that, owing to the circumstances of the district, special State assistance was required.

As it was intimated that the Government were prepared to spend considerably over a million of money under this Act, there was no lack of promoters desirous of showing them how to accomplish their aim, and far more schemes were scheduled than could possibly be carried out. So, in 1896 , came the Railways (Ireland) Act, which improved the procedure, helped to restrict the schemes to those that were really 
practicable and necessary, and further laid down that, except in the case of a railway constructed wholly or mainly in a congested districts county, the Government grant should not exceed onehalf of the total amount required for the construction of the railway. A further stipulation in regard to this State aid was that all reasonable assistance and facilities should be given by those locally interested.

In the case of some of the light railways constructed under the Act of 1889 the working companies (as was pointed out by Mr. Joseph Tatlow, manager of the Midland Great Western of Ireland Company, in the evidence he gave before the Vice-Regal Commission on behalf of the Irish railway companies), preferred to have the lines made as ordinary railways (though with somewhat lighter rails), and themselves found the balance of the capital required-more than $\$ 500$, 000 in all--to make the lines of the ordinary gauge and character. Not only this, but a number of the State-aided lines are being operated by the companies either at no profit or even at a loss to themselves.

\section{PRESENT POSITION.}

The position to-day in regard to Irish railways constructed with the help of public money may be stated as follows, on the basis of figures 
given by Mr. Tatlow in the course of his evidence (June $16-19,1908$ ) :--

Railways constructed under Tramways

(Ireland) Acts, I 860 to $188_{3}:-$

Mileage

Capital guaranteed by baronies $\ldots . .$.

Other capital

Liability for interest and loss on Ei 44,300 working (1906) :
Baronies
Treasury
$£ 31,493$
Ei 7,684

Railways constructed under Mr. Bal-

four's Light Railways Act of i 889 and subsequent Acts :-

Mileage

Free Government contributions … $E_{10} \mathrm{I}, 55^{\frac{1}{2}}$ miles

Capital guaranteed by baronies ... £277,000

Liability for interest and loss on working (1906) :-

Baronics

Treasury

Total mileage of Irish railways...

Total length of railways under the

Tramways and Light Railways

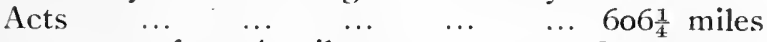

Percentage of total railways ... ... 88 per cent.

Liability for interest and loss on working (1906)-

Baronies

Treasury

Total number of lines included in figures

Number on which working expenses exceed receipts

E.35, 190 E20,87I .3 .363 miles

The 3,363 miles of railway in Ireland are at present owned by 38 railway companies, of which 28 are working companies, though of 
these the number which are of sufficient importance to count among the "principal" companies is only six. So recently as 189 I there were 17 more companies, but these, with 503 miles of lines, have since been absorbed by the "great" companies, which have become entitled to that designation mainly because of successive amalgamations of smaller lines.

\section{THE QUESTION OF EXTENSIONS.}

The facts I have' already given show that, if still more railways are wanted in Ireland, the machinery which has already supplied 600 miles with local or Imperial assistance is still available without any reason for a resort to nationalisation on this ground, at least. In fact, Mr. George A. Stevenson, Commissioner of Public Works in Ireland, said to the Vice-Regal Commission in reference to certain figures he gave in the course of his evidence (December 13, 1906) :-

Mere figures do not give a fair idea of the value of the extensions; but the map will show how railways have been gradually pushed forward ints remote and, in some cases, unpromising localities, so that with one or two exceptions it would be difficult to point to any considerable district not within reasonable distance of a railway, having regard to the fact that railway extensions must have some relation to the population to be served and its distribution and the amount of the traffic to be expected.

In this connection I may recall the fact that the 
Duke of Devonshire's i 865 Commission said in their report:- "Ireland has certainly no reason to be dissatisfied with the extent of railways constructed in it under the present system. In proportion to the resources of the country it is fully equal to that of the lines in the rest of the United Kingdom." These observations were written over 40 years ago, and since then many new lines have been constructed; but there still exists a certain demand for railways to be constructed with a total disregard for the qualifications mentioned by Mr. Stevenson. So long as the Government find the money, such lines will always be asked for, and nationalisation would give a distinct impetus to fresh requests. It is noticeable, however, that when any of the loss falls upon the district served, the anxiety for unproductive lines is much less acute. I gather from a question put by Mr. Sexton to Mr. Stevenson (574), that in 1905 the operation of 22 lines of railway resulted in a levy upon the baronies, "very heavy in some cases," and that in the case of the Cavan and Leitrim Railway " the ratepayers have been so worried by the heavy liability that they will not consent to even a small extension of a few miles."

Mr. Sexton's suggestion was that "future light railways in Ireland will very likely have to be built by some central authority provided with public funds." I take it this means, in other words, that such railways, provided for districts 
where the traffic is inadequate to cover interest and working expenses, are to be regarded as charitable institutions, supported by the compulsory contributions of the general taxpayer.

Turning once more to the Report of the I865 Commission, I further read there, in reference to I reland :-

When capitalists undertake to construct a railway for the conveyance of persons and things at a lower rate than they can otherwise be conveyed, they unquestionably confer a great advantage on the public; but this furnishes no reason for the Government undertaking to reduce still further the cost of conveyance by giving the aid of its credit, or by making good the loss out of the public treasury.

The proposal to give a subsidy is, therefore, to pay out of the public treasury for a further reduction of the cost of conveyance, when a great reduction has already been made by means of a special contrivance, but to pay nothing when. no reduction has been made because the ordinary road is obliged to be used.

\section{NATIONALISATION AND SAVINGS : DIRECTORS.}

The fact that there are still so many separate railway companies in a country of no greater proportions than those of Ireland is regarded as a strong argument in favour of nationalisation of the Irish lines, at least; the advocates of this proposal laying special stress on the savings which they think would be effected in the fees paid to all the different boards of railway directors. 
At first sight there certainly does appear to be good reason for their argument. But, on going into details, one finds that the total remuneration of the Irish railway directors in 1906 amounted to $£_{1} 8,656$, which works out at an average of $\mathcal{E} 49$ I per company, and $\mathcal{E} 79$ per director; while as the directors of the six principal companies received $\mathcal{E}, 5,250$ of the total, this leaves only $\notin, 3,406$ for the remaining 32 companies-an average of $\$ 106$ per company. Chairmen and directors of small companies get, practically, out-of-pocket expenses only; those of the large companies may, in return for their fees, be required to attend at the head offices five out of six days a week, and spend much time in committees.

The figures given do not suggest that, after paying the salaries of those who would work the State department taking the place of the boards of directors, under a nationalisation scheme, there would be much to go towards a general reduction of railway fares, rates and charges in 1 reland. Far more than $\mathcal{f}$ i 8 ,ooo a year, one would think, might be saved by the existing companies, if absolutely necessary, without resorting to an experiment which is certainly speculative, and would be attended by some degree of financial risk.

Incidentally I might mention that one of the witnesses examined before the Vice-Regal Commission, Mr. O'Dea, of the Irish Reform Asso- 
ciation, suggested in his evidence that by the conversion of the Irish railways into one system, there might be effected a saving of a quarter of a million. One of the Commissioners, Mr. J. A. F. Aspinall (General Manager of the Lancashire and Yorkshire Railway Company), thereupon asked, "Supposing your figure of a quarter of a million to be right, have you ever divided the total tonnage of goods carried over all the Irish railways into that quarter of a million, so as to be able to assign how much you would be able to reduce the rate per ton to a particular place?" The witness replied, "Well, I never made that calculation." If the quarter of a million yielded such presumably small results, worked out on this basis, what would be the case with the aforesaid balance of $\mathcal{E}^{18,000}$ to be saved by the abolition of the boards of directors-even if we increase the amount somewhat by throwing out a few chief officers as well?

THE IRISH RAILIVAY CLEARING HOUSE.

It is further assumed that under a system of nationalised or even unified railways in Ireland there would no longer be any need for the Irish Railway Clearing House, and that money would be saved in this way. Once more we get an apparently sound proposition. But it seems that the staff of clerks engaged in the establishment in question are concerned far less in regu- 
lating accounts between different railway companies in Ireland than they are in dealing with the charges, etc., on traffic passing between Ireland and England. The Clearing House would thus certainly have to be retained.

\section{THE SPENDING DEPARTMENTS.}

Nor, according to the railway witnesses examined before the Vice-Regal Commission, would there be much chance of a nationalised railway system in Ireland effecting substantial savings in the three great spending departments -traffic, permanent way, and locomotive.

From the point of view of a Prussian State railway administrator the goods service in Ireland would certainly be open to criticism. In order to facilitate despatch, and satisfy, especially, traders who keep small stocks and want early delivery, goods received by the railway companies up to six o'clock in the evening are loaded at once, sent off by night trains, and (with few exceptions) delivered early the next day at any point along the line. The running of the night trains increases the expense, and the prompt despatch of consignments means that the average load carried per railway wagon is only about $2 \frac{1}{4}$ to $2 \frac{1}{2}$ tons. Nationalise the svstem on the Continental model; engage a Prussian railway expert, if necessary, to show the Irish State railway people how they should operate the 
lines on the most economical German plan, and some decrease in working expenses might then be anticipated; but it would be mainly by keeping back consignments for a day or two, or even longer, whenever necessary, in order to make up better loads, and by charging double rates to traders who wanted to have their consignments sent by "fast" goods trains, or four-fold rates for despatch by the "express" of which the present goods service in Ireland is practically the equivalent. Economies through nationalisation? Why, certainly, they could be made, in the way here suggested. But what would the Irish traders say?

The prospect of savings on permanent way is doubtful; that there might have been savings in this direction in the past is undeniable. "In the early days of the system of railways," Mr. Stevenson told the Vice-Regal Commission, " the Board of Trade requirements were really excessive, very excessive, and they to some extent recognised that by revising their requirements as to signalling. For instance, certain arrangements in the lines built under the Act of 1896 are much less burdensome than those built under the Act of 1889." “ "Ireland, a sparsely populated agricultural country," said Mr. Tatlow, before the same authority, "is subject to the same legislative enactments, the same Board of Trade regulations and requirements as England; the same costly signalling, block 
working, continuous brakes, foot-bridges, platforms, etc., and the same restrictions with regard to mixed trains. These have greatly increased the cost of railway working."

As for savings in the locomotive department, some of the best economies already claimed by the Irish companies of late years have been through spending money on the acquiring of more powerful locomotives capable of drawing heavier loads, thus reducing the goods train mileage run.

\section{INCREASES IN EXPENDITURE.}

Assume, however, for the sake of argument, that, in one way or another, railway nationalisation in Ireland might lead to a reduction of expenditure in some directions. Would there not, in all probability, be an increase in others?

When the Government acquired the railways, demands would be made for a further provision of unremunerative lines-notwithstanding $\mathrm{Mr}$. Stevenson's remarks on the approximate conpleteness of the present system. Residents in districts already supplied with railways of a primitive type-though, perhaps, now serving their purpose-would want to have them reconstructed and brought up to date. Small lines taken over and made available for through traffic as part of one large unified system would have to undergo considerable improvements, involving much expenditure, to place them on the 
same level of efficiency as the remaining portions of the system.

Many of the smaller railways in the backward parts of Ireland are narrow-gauge lines, built to serve exclusively local purposes, and with no idea that it would ever become-necessary to change them to the standard gauge and link them up with the net-work of Irish railways in general. These lines, especially, would form no real asset, but involve a considerable expenditure, either for a larger company or for the State, in taking them over, and this, too, without any prospect of an equivalent increase in traffic.

Permanent way, rolling stock, and railway stations on all these smaller lines would need to be brought up to the higher standard. Bridges would require to be re-built, curves and gradients would require modification to adapt them to a heavy broad gauge railway; in fact, the lines would practically have to be re-constructed.

When all this had been done, and the previously local and independent lines had been turned into part of a State system, salaries and wages would have to be levelled up at a very considerable expense.

Then the traders and travellers who are prepared to accept all sorts of excuses for the shortcomings of small Irish lines, in out-of-the-way places, owned by companies which can sometimes only be kept going by baronial guarantees, 
would be far less tolerant when those lines were taken over by the Government or even by a "great" company. They would. want better services and better accommodation, and the traders, especially, would further be more disposed to send in "claims" on any and every possible occasion.

\section{SOME RISKS AND AN ALTERNATIVE.}

How, under State ownership, all these improvements and concessions, together with substantial reductions in rates and fares, would be demanded with never-ending persistency, either from the State railway department or from the Government, and how refusals would be made the subject of grievances to be brought before Parliament itself, can be readily imagined by those who are familiar with the nature of Irish politics in general.

Without going to the extreme of State purchase, it should be possible to reduce still further the number of railway companies in Ireland by continuing the policy of amalgamation; and there are certainly a number of the lines that might thus be dealt with, although there are others, operating independently of the large systems, which, small as they are, may be already serving a very useful purpose, and one that would not necessarily be increased by the loss on their part of independent existence. The advantages of greater unity, while still pre- 
serving the element of competition, might thus be secured without the various risks of a system of State ownership under which competition would no longer exist at all.

\section{IRISH TRADERS' GRIEVANCES.}

With the full catalogue of grievances advanced by Irish traders and others before the Vice-Regal Commission on Irish Railways during the course of over two years' sittings, I cannot attempt here to deal. Many of those grievances were certainly of a kind that called for inquiry and explanation, and to this extent, at least, the sittings of the Commission will do good. Still more were based on anomalies or misconceptions arising out of geographical factors, water competition, or other circumstances which may well have led to erroneous impressions. In one instance a witness advanced figures to prove that the railway fares in Ireland are substantially higher than those in England. These figures were for many months accepted in Ireland as trustworthy, until the first of the railway officers to be called showed that the witness in question had simply divided total passenger receipts by total number of passengers, without taking into account the average distance travelled. He had, in fact, ignored the enormous number of penny and twopenny fares in and around London; whereas in Ireland, where there is no suburban or inter-urban rail- 
way traffic on anything like the same scale of magnitude, the average distance travelled per passenger is substantially higher, and the average payment per third-class passenger is, consequently, higher than in England; though when like distances are compared, the average Irish fare is lower, owing, mainly, to the practice of charging considerably less for a return ticket than the sum of two single fares.

As regards the grievances of individual traders, I give a few examples which I have come across in looking through the published evidence :-

(1) A complaint that sevenpence was charged for the transport of $28 \mathrm{lbs}$. of tobacco carried from Belfast to Monaghan, this being, the witness said, at the rate of $46 \mathrm{~s} .8 \mathrm{~d}$. per ton, instead of the nominal rate of $18 \mathrm{~s} .6 \mathrm{~d}$. per ton. (He had, of course, been charged the "small parcels" scale.)

(2) A complaint by a witness that he had had a beast killed in transit. Asked when it occurred, he replied "about 25 years ago."

(3) A complaint that the railway companies do not provide cases in which dead pigs can be hung up in the vans, and so removed direct to the markets.

(4) A complaint that the rate of $3 \mathrm{~s}$. $6 \mathrm{~d}$. per ton, including terminals, for carrying grain a distance of 17 miles, was excessive.

(5) A complaint that the rate for Irish bacon 
from Enniskillen to Liverpool was higher than that for American bacon from Liverpool to Enniskillen; though the witness admitted that if the Irish bacon were packed in boxes (like the American bacon) instead of in bales, it would go at the same rate. Asked why he did not adopt the system which allowed of the better loading of the wagons, and thus secure the lower rate: he replied, "The trade won't allow us."

WHAT THE COMPANIES HAVE DONE.

It will be for the members of the Vice-Regal Commission, as the result of their exhaustive and most painstaking inquiry, to express their views alike on these and on the other much more weighty questions that have come before them; and it will certainly be interesting to learn whether they think that the indictment against the Irish railway companies (who have avowedly been "on their trial") has been proved, or whether they are satisfied that the companies have had a greater and more practical desire to serve Irish interests than they have received credit for.

The evidence has, at least, brought out some points in favour of the railway companies which can be set against the complaints and grievances.

To get fish on the English markets as quickly as possible, the Irish railway companies run special trains at an average speed of 35 miles an 
hour, for distances up to 240 miles, with loads of as small a quantity as ro tons or even less; while fish merchants not certain of the best market are allowed to consign to Holyhead, Liverpool, or Fishguard, the consignments to be distributed thence in accordance with telegraphed instructions. An inclusive throughout rate is charged, although there are, in effect, two complete transactions.

Of live-stock fairs in Ireland there are, on an average, 20 a day, excluding Sundays. The traffic to and from these fairs is worked mostly by special trains. In 1906 one of the Irish railway companies ran I6I specials, and another ran 119 specials, each with ten wagons of live stock, or fewer than ten. To allow of live stock being shipped by a particular boat a railway company will despatch a special train, in no way warranted by the number of wagons run. In the case of cross-country traffic they also forward live stock by passenger trains, at the goods train rates, in order that time may be saved.

In a large number of instances specially low rates are granted to encourage struggling industries, while nearly 8o per cent. of the goods traffic on the Irish railways is carried at special rates. It was suggested by some of the witnesses that the railway companies required an industry to be full grown at its birth before making concessions. To this it was replied that the companies often did not wait even to be 
approached by the parties interested, but themselves took the initiative, acting on information supplied by station-masters and canvassers, although the companies liad had some unfortunate experiences in the way of giving rates and facilities which the results did not justify. Farmers and others, it was added, could get further advantages if they would only co-operate more freely, and avail themselves of the existing lower rates for large or grouped consignments, instead of sending individual consignments at the higher rates.

A substantial proportion of the passenger traffic in Ireland is carried at considerably less than the ordinary fares. Among the special facilities thus offered are market tickets (at slightly over a single fare for the return journey) issued weekly at a large number of stations; afternoon tickets, to allow of residents within 30 miles of Dublin going there to do shopping, or to visit theatres, concerts, etc.; traders' season tickets at reduced rates; week-end tickets at about a single fare and one-eighth ; tourist tickets; reduced fares for agricultural shows, exhibitions, sports, industrial association meetings, etc.; and even free season tickets for a term of years to persons erecting a new house within a given radius of certain stations. So far does the general practice extend that Lieutenant-Colonel Plews, general manager of the Great Northern of Ireland Railway Company, informed the Vice-Regal Com- 
mission (June 19, 1908) that on his company's lines $5 \mathrm{I}$ per cent. of the passengers carried in 1905 travelled with tickets issued at cheap fares.

The Irish railway companies have also done much to foster travel in Ireland by erecting or taking over and conducting well-equipped hotels in the interest of the tourist traffic, their expenditure under this head alone in recent years exceeding $\notin 500,000$.

There is no need for me to go into details as to the money expended in Ireland on the improvement of permanent way; the provision of better rolling stock (including breakfast and dining cars); the enlargement of stations, etc.; nor need I reproduce the available statistics showing that, although the population of Ireland has steadily declined, the traffic on the Irish railways has, during the last 5 years at least, steadily increased. What I am here mainly concerned in is the suggestion, which I now make, that, in view of the facts already given, it is very doubtful indeed if State ownership of the Irish railwaiys could have done more for the Irish people, even if it would have done anything like so much.

AN ELECTIVE IRISH AUTHORITY.

I will not attempt to indulge in any forecast of the result of the inquiry by the Vice-Regal Commission on Irish Railways; but on one phase of the general subject dealt with by them.I should 


\section{Railways and Nationalisation.}

like to express a personal opinion, inasmuch as it falls within the scope of the matters which the present volume is designed more especially to discuss.

Questions put to various witnesses by $\mathrm{Mr}$. Sexton were to the following effect:-Did they not think that an elective Irish authority, acting under the influence of, and being responsible to, Irish opinion, and respecting the wishes and interests of the people, with a working board of railway experts subject to this supervising authority, would be much more likely to accomplish the necessary reforms on the Irish railways?

My own reply thereto would be given thus :-

The experience of other countries, and especially of the British Colonies, shows that under a condition of State ownership and operation it becomes practically impossible (unless in the case of an exceptionally strong Government) for the railway experts who nominally control the railways to conduct them efficiently, on business lines, and free from those political influences which must inevitably prevail more or less when the supervising authority is a popularly-elected body, itself subject to pressure from electors or othērs who are inspired mainly by considerations of self-interest, and know nothing of, and perhaps care less for, those manifold complexities and intricate problems by which the operation of railways under really sound conditions must necessarily be attended. Such political influ- 
ences may be kept down somewhat in a country with an autocratic Government like that of Prussia; but in Ireland there would be, in a preeminent degree, the two-fold risk: (I) of members of the supervising authority seeking to retain the favour of their constituents by securing for them railway concessions regardless of the effect thereof on the railways or on the public funds on which they would expect to draw; and (2) of Irish traders and others themselves endeavouring to force such action on their representatives, whether the latter approved of it or not.

Looking, therefore, on the one hand, at the example of the colonies, and, on the other, at the political conditions in Ireland itself, my own opinion is that the plan of having either a Stateowned, or even an amalgamated, system of railways in Ireland controlled by a popularly-elected local body would create very great difficulties, would produce far less eflective management than at present, and, apart from the great probability of political complications, would lead to such financial results that the lines could only be efficiently maintained by becoming a charge, more or less, upon the general taxpayer.

I am, therefore, firmly convinced, in my own mind, and as the result of such inquiries as I have been able to make, that, whatever the future of the Irish railways may be, and whatever 
$35^{6}$ Railways and Nationalisation.

changes or reforms in the Irish railway system may otherwise be found desirable in the interests of the community, it will be to the advantage of Ireland herself that the element of commercial operation in the working of those railways should be retained. 
State Railways and National Prosperity. 357

CHAPTER XV.

\section{STATE RAILWAYS AND NATIONAL PROSPERITY.}

BY several of the witnesses examined before the Viceregal Commission on Irish Railways, the view was expressed that the prosperity of Germany, Belgium, Holland, and Denmark is greatly due to the possession by those countries of State railways; and the witnesses in question left it to be inferred that if Ireland, also, had State railways, she would be likely to secure an equal degree of economic advancement.

The industrial and conmercial well-being of any nation is, no doubt, greatly influenced by the possession of an efficient railway system, and, where this cannot be supplied through private enterprise, it is quite right that the State should meet requirements. But the principle of State ownership of railways is not essential to industrial and commercial success-a fact which is proved by the case of England, whose achievements in this direction (achievements at one time much more pronounced than those of any of the other countries mentioned) have been secured under a system exclusively of company-owned railways. Nor has Government 
ownership of railways been found requisite to the industrial progress of the United States of Anerica.

ECONOMIC POSITION OF GERMANY.

Then, looking at the purely economic aspects of the question, the great advance in the prosperity of Germany of late years has been due less to the ownership of her railway systems by individual States than to the enormous development of her coal, iron, and other industries. In regard to coal, a recent report by the British Consul-General at Frankfort shows that in 1906 the total production of mineral coa! in Germany was 136,480 ,ooo tons (as compared with $107,449,000$ tons in 1902), of which Prussia's share was 127,871 , 000. A later return, published in the "Engineering Supplement" of The Times, gives the following figures respecting the collieries in the Ruhr district of Westphalia :-

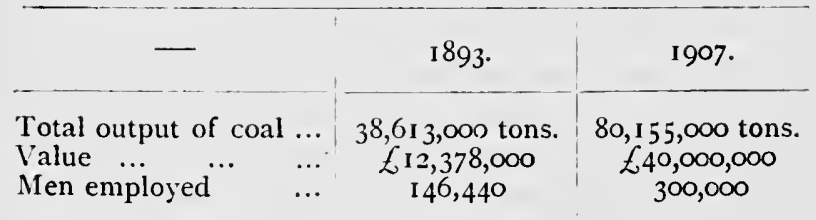

In regard to iron ore, Lorraine furnished, in 1906, over $12,000,000$ tons of this commodity towards the very great amount required by German ironworks, themselves established on 
such a scale that in Westphalia alone they give employment to 142,000 workers.

Until Ireland can control like supplies of native coal and iron ore, at least, no mere transformation in the system of railway-ownership could possibly enable her to emulate Germany's industrial prosperity.

\section{BELGIUM : HOLLAND : FRANCE.}

Like considerations apply to any comparison of Ireland with Belgium, where there are at present no fewer than 122 collieries, with 296 pits in operation, the output for 1906 being $23,609,000$ tons. 'The population is 614 to the square mile, as against 137 to the square mile in Ireland, and industries of all kinds abound, which is certainly not the case in Ireland. Holland, again, is much more indebted to water transport than to rail transport, and, as I have already shown, both Belgium and Holland are greatly favoured by their geographical position, which leads to the passing of so much international traffic through their ports; while the prosperity of France has been far more due to the thrift of her people than to the policy adopted by successive Governments in assisting the railway companies there to construct new lines, or in forcing upon them, with a guarantee of interest, non-commercial lines, of which many have been built in places where they could not possibly be made to pay. 
360 Rallways and Nationalisation.

\section{DENMARK.}

The great development, again, of Denmark is due mainly to other causes than to her possession of State railways. That country can be much more fairly compared with Ireland than the others already mentioned. Denmark, like Ireland, is of circumscribed dimensions, has few industries, and is, in fact, dependent on agriculture, though even in this respect she has no greater natural advantages than Ireland. But her agricultural workers, as a class, are extremely industrious, toiling all day, and (in the case especially of the younger among them) studying at night in order to perfect themselves in the technicalities of their business; and they have a system of co-operation which embraces every possible phase of their agricultural work, provides for the most economical forms of successful production, and ensures the best possible system of marketing.

\section{RAII.WAY CONSIGNMENTS.}

One effect of the widespread agricultural organisation adopted in Denmark has been to provide the railways there with consignments on a scale to which Irish conditions offer no possible basis of comparison. I understand that in Ireland even five-ton lots of agricultural produce, such as eggs, butter, and bacon, are rare, and that the rates apply rather to con- 
State Rallways and National Prosperity. 361

signments of a few cwts.; whereas in Denmark the average consignments from individual traders or co-operative societies are:-Butter, 2 tons; bacon, 9 tons; eggs, 15 cwt. A record number of pigs killed in Denmark in a single week, for conversion into bacon, is 48,000 .

Butter for export is produced exclusively in factories situated in all parts of Denmark. The farmer supplies milk only. In the morning be leaves the full churns on the high road, and there they are collected by a representative of the factory, who, in the same way, in the afternoon, returns the churns with the skim milk for the pigs. From the factories the butter is sent to Coperhagen or Esbjerg for shipment. The average distance the consignments of butter, bacon or eggs would be carried by rail before reaching Esbjerg ranges from 77 to 130 miles. No through rates are granted from these inland stations to England. Through rates apply from the Danish port only.

COVERNMENT SUBSIDIES ON TRANSPORT

To facilitate the export of agricultural produce to England, the Danish Government grant subsidies to the extent of 370,000 kroner, or L.20,555, a year. to the steamships engaged the rein, those on the Esbjerg-Parkeston route receiving $\mathcal{E}_{14}, 444$, and those on the EsbjergGrimsby route $\mathcal{E}_{6,111 \text {. The principle of direct }}$ financial assistance being thus established in 
respect to one branch of the export service, that, namely, of the sea journey, I would suggest that the rates charged on the other branch, the rail journey in Denmark, may also have been arranged (apart from the question of consignments in bulk) on a more or less subsidy basis.

\section{INCIDENCE OF PRODUCTION.}

Looking at the various conditions which may influence the very considerable production in Denmark, the extensive system of organisation to which I have already referred naturally holds the first place. But there are other influences at work, and among these I might mention that in Denmark there are fewer race meetings, sports, and shows, and fewer feasts and festivals (religious or otherwise) than in Ireland to give the excuse for day or half-day holidays. Excursions and trips are of rare occurrence, and there is, again, a great saving of time on the part of the farmer in the absence of all necessity for his attending markets in order to make purchases or effect sales. He buys all necessaries at his agricultural co-operative society's store in the village, and his products he hands over to the co-operative undertakings, which pay him cash and relieve him of all further trouble. In this way he saves one or two days a week, as compared with the average non-associated farmer in the United Kingdom, and the time 
State Railways and National Prosperity. 363

thus gained can be devoted to management and production.

\section{SUNDAY WORK.}

In most of the co-operative dairies in Denmark there is no cessation of labour even on Sundays. It is argued that inasmuch as the cows give their milk and the pigs must be fed on Sunday the same as on other days of the week, so dairy work also must be done then. It is true that differences of opinion have arisen on this question. In certain districts a number of farmers, influenced by religious sentiment, have started a movement against doing any work at all on Sundays, even in dairies; and they have split off from the general organisations, and established independent societies operating on the principle of strict Sabbath observance. They form, however, the exception rather than the rule.

\section{WINTER DAIRYING.}

Another material consideration in regard to production in Denmark is found in that matter of winter dairying in connection with which the suggestion has been made that Irish farmers would do well to follow the example of the Danes in this respect.

Winter dairying was started in Denmark about thirty years ago. At that time prices for butter were extremely high, because the practice in question had not hitherte been adopted, and no 
364 Railinays and Nationalisation.

supplies were coming in the winter from any country in the Northern hemisphere. Anxious to promote their agricultural resources, the Danes adopted the system. It involved a substantial outlay in the construction of buildings and the importation of special food supplies; but a very considerable degree of success was obtained in the way of creating an all-the-yearround export trade.

To-day, however, the situation is not the same as it was at first. Differences in seasons and the facilities afforded by refrigeration enable Australasia to send her summer butter to British markets in our winter. Although, therefore, producers may now make a praiseworthy effort to set up winter dairying in Ireland, they could not hope to do so under the same favourable conditions as those which enabled Denmark to establish her own position in this respect.

THE DANISH PEASANT AT HOME.

While, however, the conditions in Denmark certainly do tend to swell the volume of production, and hence to increase the competition which Irish producers have to meet in English markets, it is extremely doubtful if the average Irish peasant would be willing to exchange his way of life for that of the average Danish peasant, even in the interest of an assumed economic advantage. 
The darker side of the picture was well painted in an address given at the National I iberal Club on November IIth, 1907, by Mr. Erik Givskov, an authority on the subject of small holdings in foreign countries. He showed that the Danish peasant generally lives on black bread, skim milk, margarine and American pork and bacon, while he has to export all the good things he produces to England to obtain cash for his taxes and interest on mortgage debt; that the net income of Danish peasant farmers who have obtained all the prizes it is possible to get for excellent culture exceeds only in exceptional cases $\mathcal{E}_{5}$ o a year; that a peasant farmer with $\mathrm{r}_{3}$ acres of land earns on an average $£ 23$ to $£ 24$ a year after having paid his taxes and interest on his purchase money, and that while, several years ago, about 60 per cent. of the value of all agricultural property in Denmark was mortgaged - to a very great extent to German capitaliststhe mortgage debt has, since then, very considerably increased.

In a book on "The Transition in Agriculrure," which I myself published in 1906, I summed up the position in Denmark by saying that " many a Danish farmer is, with all lis family, working for long hours, and looking to England for the profits he makes on his produce, not so much for his own gain as to satisfy the demands of his German creditors." 


\section{DENMARK AND IRELAND COMPARED.}

Questions put by Mr. Sexton to various witresses examined before the Vice-Regal Commission show that that gentleman is inclined to attach great importance to the value of State-aid as given, or assumed to have been given, in Denmark. To Mr. John F. Power, president of the Limerick Chamber of Commerce, he said, at the sitting on November 2 I, I906:-

What can be a sadder reflection to an Irishman than to know that Denmark, in the course of ro years, has increased its exports to England in food products, such as we produce, from $£ 3,000$, 000 to $£ \mathrm{I} 7,000,000$ a year, just because their Government gives them State railways and steamers and organised industry, while the Irishman is left to shift for himself, or be subjected to a burthensome through rate?

Personally, and as the result of my own inquiries in Denmark, I dissent entirely from the suggestion that this great export trade has been built up by Denmark, "just because" of the action of her Government. My own view is that the Danish people are far more indebted to themselves in the working out of their economic salvation than they are to their Government. The secret of their success is to be found in their personal qualities, in their energy and foresight, in their full realisation of the needs of the situation and their determination to meet them, rather than in such State aid as they have 
State Railways and National Prosperity. 367

received: It was the people themselves who started that system of heath reclamation which was to make some amends to Denmark for the loss of Schleswig-Holstein, following on the war with Prussia. It was mostly the peasant farmers who worked out that system of agricultural organisation which has effected such revolutionary changes in Denmark's position. I cannot here stop to repeat the story I have told elsewhere; but any suggestion that this admirable system of organisation .was "given" to the Danish people by their Government is in no way supported by actual facts. What the Government really did was to give them a well-planned system of agricultural and technical education, which helped to complete the scheme of organis. ation the people had originated for themselves. It was not until these and the various other fundamental conditions had prepared the way for a substantial increase in production that the State railways and the subsidised steamboat services could begin to play a part which, though certainly helpful, was subordinate altogether to those main issues for which the full credit must be given to the Danish people.

In the list of exports from Denmark during r 907 three items alone account for $\mathcal{E}_{17}, 35^{2}, 180$,

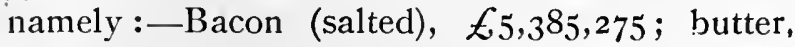

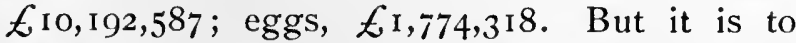
her economic and social conditions rather than to the fact of the ownership and operation 


\section{.368 \\ Railways and Nationalisation.}

of her railways by the State that Denmark is indebted for her remarkable economic success, and it can hardly be suggested that Ireland would have any chance of sharing, or even of ('mulating, that success by a transfer of her own railways to State management unless a corresponding transformation were brought about, also, both in her system of agriculture and in the habits and disposition of her people.

Mr. Sexton reverted to his theory when, on February 28, 1907, Mr. Alexander Cooke, vicepresident of the Council of the Belfast Chamber of Commerce, gave evidence. I quote the following from the official report, though I leave those who are more intimately acquainted with the Irish people than I am myself to say whether the witness's estimate of them is warranted or not :-

Mr. Sexton: I should be very glad to adopt a system which would give to this poor country any. thing like the development which has been achieved in Denmark, Belgium, or several other countries. Mr. Cooke: In Denmark the Government has had to raise the rates. They could not live without it.

In Denmark you have a great commercial develop ment that the exports have increased in thirty years from three millions to seventeen millions a year, and they could very well afford to make a subvention from the taxes?-If you could make the people industrious in Ireland as the Danes are, we would have just the same result. In Belgium you won't find a cow's grass in the whole enuntry; you won't find a man who is lying on a ditch looking at a cow grazing. Every acre of land is cultivated, raising 


\section{State Railuays and National Prosperity. 369}

produce for export. There are two steamers bringing produce from Belgium into England at Goole in the day, because the people are industrious.

You must give the people occasion for industry. You have not got the industrious people. You are making a comparison between an industrious people and a people who are lazy.

I say the system of railway rates in Ireland has prevented the profitable employment of capital, has deprived the people of the means of profitable employment, and thereby has prevented industry.If you carried their produce for nothing you would not make them raise it.

What do you mean?-I mean they are too lazy. They would not work.

All the Irish people?-You have in the west of Ireland hundreds of men who go to Scotland every harvest time, and come home with their $f^{\circ} 8$ or $\mathcal{E}_{\mathrm{o}}$ earned in their pocket to pay their rent. They come home and sit down and smoke, and, unless planting a few potatoes in the spring before they go away again, they don't work any more.

Because the wretched holdings they have offer no incentive to industry. - You should see the wretched holdings those Danes and Norwegians have who live in comparative comfort; but they don't waste their money drinking. 


\section{CHAPTER XVI.}

\section{BRITISH RAILWAY POSITION TO-DAY.}

Тнат the actual position of the British railways to-day is unsatisfactory is admitted on all hands--by the railway companies, in fact, as frankly as by their critics, for the companies find that working expenses are steadily advancing, while revenue is too often growing less. Meanwhile there is much talk of excessive competition, waste, need for economies, and so on, often with a concluding argument that nationalisation would supply the best remedy.

The present difficulty is the climax to a long series of struggles between two antagonistic principles or conflicting forces.

\section{THE POLICY OF AMALGAMATION.}

On the one hand the history of the British railways has been mainly that of the amalgamation of a host of originally small or comparatively small companies by larger ones, until the great systems of to-day came into existence. The London and North-Western Railway Company, for instance, was formed in 1846 out of the London and Birmingham, the Grand Junction and the Manchester and Birmingham 


\section{British Railway Position To-day. $37 \mathrm{~L}$}

companies, and it has further amalgamated 49 undertakings, exclusive of those acquired in combination with other large companies. The Great Western Railway has been created out of no fewer than 107 distinct concerns, apart from joint amalgamations. Thirty years ago the Great Western route from Paddington to Penzancé was divided among five distinct companies, and the charms of the Hinterland of Penzance, now visited annually by many thousands of tourists -thanks to the splendid through services of express corridor trains available-were practically unknown except to the most venturesome of Englishmen. Other of the leading railway companies have been made up, and have con ferred great benefit on the community, in the same way. So all the talk by the nationalisation party of the advantages of unified railways, and the evils of undue competition, of which one hears so much, is a very old story, and onc on which the railway companies, by their amalgamation policy, have been acting for decades past.

\section{THE POLICY OF COMPETITION.}

On the other hand, and directly conflicting with these efforts to develop the railways on sound commercial lines, there has been the persistent attitude of Parliament itself in stimulating the element of competition in every possible direction, regard for the position of companies 
already established being invariably ignored in the supposed interests of the public. Whereas, in France, successive Governments have allotted separate spheres of influence to the great railway companies there, allowing each to have its own territory, in England the idea of towns being served by two railway companies, so as to ensure competition, has always been favoured by Parliament. Not only this, but what has repeatedly occurred is that, as the result of like considerations, powers to construct new and competing lines have been given to speculators or syndicates seeking only to get themselves bought up by the companies whose interests were threatened, the said powers being abandoned when the aspirations entertained have not had the desired success. Further than this, it has happened that when powers to construct a new railway have been sought (1) by an established and responsible railway company in whose recognised district the line would run, and (2) by either an "outside" railway company or a speculating syndicate, the Parliamentary Committee has favoured one of the latter over the former-in order once more to ensure competition.

COMBINATIONS IN SELF-DEFENCE.

As the outcome of these two antagonistic policies the railway companies have, in selfdefence, found it expedient to " pool " traffic, or 
to make other arrangements between themselves in regard to rates, routes, and facilities, in order especially to protect the interests of the railway proprietors. This is one reason why the companies have not resorted of late years to those competitions in rates into which, apparently, it was expected they would be driven. But when they have gone further, and have sought by means of combinations to check waste, excessive competition in services and the other evils held up against them by the nationalisers as a cause of reproach and a reason for State purchase, County Councils, Town Councils, and other local authorities, together with Chambers of Commerce, trade associations and newspapers, have raised an outcry with the design either to prevent any such arrangement. or to render it of no avail.

This position has been mainly due to the attitude taken up by Parliament alike in its encouragement of competition regardless of all cost and consequences to the companies in possession, and in the example it has set to the country by showing extreme jealousy and suspicion of all railway combinations. But if the competition thus deliberately fostered has become an evil, and if the further unification hitherto checked and discouraged be indeed the effective remedy, then it is clear that Parliament is now face to face with a difficulty chiefly of its own making and maintenance. 
374 Railways and Nationalisation.

THE SOUTH-EASTERN AND CHATHAM AND DOVER COMBINATION.

What has happened when two railway companies seek to obtain Parliamentary sanction to a working union between themselves is well shown by the experiences of the South-Eastern and the London, Chatham and Dover Railway Companies in 1899 .

The extremely keen competition carried on for many years between the two companies in question had had a distinctly prejudicial effect on their finances, and the proposed working agreement was intended to check much of the waste that was going on. But no sooner were the intentions of the companies made known than a campaign of the most active, if not sometimes of the most virulent type, was stirred up against them.

The nationalisers make a strong point of the fact that competing companies run trains which start and arrive at about the same time, when, under a unified management, one train would suffice, and money could be saved by cancelling the other train or trains.. Mr. A. Emil Davies says in regard to "waste" such as this:-

All the money that is spent by the companies in needless competition, it must be remembered, has to be made up somehow or other, if they are to return any interest to the stockholders, and it is on the traders and the public that the burden ultimately falls. 
British Railway Position To-day. 375

As it happened, the South Eastern and the Chatham and Dover companies were running duplicate services of identically the same type as those here mentioned. Trains for Margate and Ramsgate, Rochester, Dover, and other places were leaving and arriving on each system at practically the same time, and the working union proposed, in effect, to do precisely what the nationalisers say ought to be done, and could be done under State ownership. Every town, however, where these dual services existed at once took steps to oppose the companies unless they agreed to give them " no worse train service " than they had already-in other words, to continue the duplicate trains as before, regardless entirely of any question either of waste or of economy. Local authorities, traders' organisations and local residents throughout Surrey, Kent and Sussex rose in arms, as it were, against the companies, and enterprising halfpenny newspapers, seeing in the campaign a chance of self-advertisement and increased circulation, fomented the agitation to the utmost of their power.

\section{INTIMIDATION AND SURRENDER.}

That the two railway companies concerned were intimidated by the extreme vigour of the opposition is undeniable. So much was this the case that, with a view to smoothing their course before the Hybrid Committee which was 
to deal with their Bill, they proceeded to make such concessions to public clamour that they rendered the effect of the Bill nugatory, and eventually found themselves in practically no better position than they had been in before. Not only did they feel forced to assent to a continuance of the duplicate services, but in the case of Rochester they bought off opposition by an undertaking that all express trains (except boat trains) should stop there, to suit the convenience of the local residents. This stipulation was carried out for some years, and was then allowed to lapse on an undertaking being given that Rochester should be supplied with a new railway station. To meet the opposition of the National Association for the Extension of Workmen's Trains, the companies made concessions which involved a decrease in their traftic receipts of no less than $£ 20$,ono a year.

Whether or not the companies should have surrendered so much is a question on which it is easier to pass judgment now, with the wisdom that comes after the event, than it was during the storm and stress of one of the most rabid, grasping and selfish campaigns conducted against British railways in recent years. The two companies got their Bill, but they derived little or no benefit from it. Even to-day, whenever they want to save the cost of running a duplicate or an unnecessary train on the one line or the other, they are checked by the local 
authority or some local interest declaring that any such procedure will be contrary to an " agreement" extorted from them under the conditions here detailed. The present position, in fact, was thus described by Mr. H. Cosmo Bonsor, Chairman of the South-Eastern Railway Company, at the half-yearly meeting of the London, Chatham and Dover Company on August 4, 1908 :-

They could not close any stations, or take off any trains which were unremunerative, or do anything by which they could effect marked cconomies, simply because when they went to Parliament for the Working Union Act a clause was inserted-through the pressure of various towns and traders-preventing the companies from taking off any facility which was in existence at the time. They could not even raise the price of their season tickets, or take off any of the cheap tickets, even where they were unremunerative, without going to the Board of Trade or the Railway Commissioners.

MR. ASQUITH'S VIEWS.

The grim irony of the situation will be still better appreciated when one recalls some remarks made by Mr. Asquith at Manchester, on March 13, 1908, on the occasion of the twentyfifth anniversary and banquet of the Oldham Incorporated Chamber of Commerce. I take the following from the report in The Times of the following day:-

Alluding to the attitude of the State towards the railways, Mr. Asquith said that, whilst he was not 
going to touch upon the vexed topic of the nationalisation of railways, upon one thing he thought they were all agreed, and that was that a great deal more might be done than has been done. When they looked at the enormous waste, the unnecessary expense, and the cut-throat competition, the provision of duplicate or sometimes triplicate facilities in cases where one service could suffice, and the thousand other evils attendant on the present more or less unregulated system in regard to railways, one could not help seeing that an enormous amount of money might be saved, trade better served, and shareholders have a prospect of higher dividends, if only they could introduce greater coordination, more simplicity, and greater common sense into the management of the railway system.

To what extent these remarks were intended to serve the interests of party politics I cannot say; but one can only charitably assume that, when he made them, Mr. Asquith had forgotten what actually happened when the South Eastern and the London Chatham and Dover Railway Companies, themselves recognising the evils of " waste," " unnecessary expense," "cutthroat competition," and "duplicate facilities," did, indeed, try to "introduce greater coordination, more simplicity and greater common sense into the management of the railway system."

THE BARGAINING POWER OF PARLIAMENT.

So we get to the position that not only is Parliament itself directly responsible for the creation of a good deal of the "cut-throat com- 
petition" which, to a certain extent, is at the root of the present trouble, but it is the outcry raised, and the direct intimidation brought to bear upon them, when they seek the aid of Parliament in getting rid of the evils in question that make the companies hesitate to appeal to that august assembly for help in remedying the disadvantages of their situation. In certain quarters, it is said, much value is attached to what is called "the bargaining power of Parliament" in railway matters. But it cannot be to the interest of the community that the possession of these powers by Parliament should encourage local authorities and others to levy what is practically blackmail on the companies before the latter can get authority to do things which Mr. Asquith himself says they ought to do, and even scolds them, indirectly, for not doing.

In view of the considerations here presented, it is certainly significant that when, in I904, the London and North Western Railway Company and the Lancashire and Yorkshire Railway Company made the working arrangement which came into operation on January I, I905, they kept the terms of that agreement strictly within the scope of their existing powers, so that the need did not arise for their securing Parliamentary sanction.

TRADE AND TRAFFIC.

Another important consideration, not fully 
appreciated by the average trader and his political sympathisers, is that under the trading conditions of to-day - and owing in part also to the influence of the constant criticism and agitation directed against them-the railway companies have to do a great deal more for their money than was formerly the case. In effect, the ratio of increased cost both of handling and of clerical work exceeds the ratio of increase in tonnage and receipts, the items of working expenses being thus swollen in greater porportion than the items falling under the head of revenuc.

Personally I regard it as so essential to a full understanding of the railway position that the conditions thus briefly indicated should be realised by the British public that I have begged, and have obtained, permission to reproduce here the following very clear and able report, drawn up for his general manager by the chicf goods manager of one of the leading raitways, and not originally intended for publication :-

In order to work with as little capital as possible and to minimisc the risks from changes of market conditions, the retailers and local agents keep but little stock on hand, and clepend upon quick transit for the exccution of the orders they receive. As a consequence, instead of large consignments as formerly, the railway companies are called upon to convey small separate lots at more frequent intervals, and with extreme cxpedition and regularity of service. Hence the increase in the number of invoice entries per ton; and, although this process 


\section{British Railway Position To-day. 381}

of change has been going on for some years, it still continues, and it does not appear that a level has yet been reached. This increased subdivision of the traffic not only causes a direct increase in accounts work throughout, but also reacts relatively upon the correspondence.

The keen competition of the present day is responsible for a considerable amount of work additional to that performed in the past. Traders have readily taken advantage of the rivalry between the various carriers to obtain many concessions in the form of extra services and special conveniences. In this way large collections of small or separate packages sent in by stores or leading firms for consignment to their customers are so dealt with that they necessitate a great and increasing amount of handling and clerical work. The arrangements in question are very convenient for the traders, but they make it more difficult for the railway company to get a fair profit on what is done.

Then large firms in London have a number of branches in the provinces, and as supplies for the same are replenished daily from the principal store in London, it means that a quick transit is cssential; they expect that goods despatched from their store in London, say, on a Monday, shall be delivered at their shops in the provinces in sufficient time the next morning to enable them to unpack the parcels, and get them out of the way before their customers arrive.

Demands from traders for services of this character have become greater during the past few years, and, what is more, they have not been confined to traffic such as provisions, etc., but more expeditious services are demanded for coal and other mineral traffic, coal merchants nowadays paying far greater attention than formerly to the working of their wagons when passing over the railway either full or empty. 
There is a greater tendency now on the part of traders to claim for damages to goods, be they ever so small, and the consequence is that in some instances additional staff has had to be employed to meet the growth in the claims work at the stations and the district offices.

The system under which small traders, whose carriage accounts do not entitle them to ledger accounts, are allowed credit (principally on a weekly basis), has been greatly extended by railway companies in order to find favour and secure their business; and the result is that larger numbers of accounts have to be collected by the clerical staff, correspondingly fewer items being collected by the carmen on delivery.

Many of the large stores and others doing an extensive retail trade now send practically all their small parcels " carriage paid"; the charges, however small in amount, cannot, as a rule, be obtained by the company at the time of consignment, and have to be specially collected afterwards.

The extension of the telephone system throughout the country has contributed in no small degree to the increase in the clerical expenses of the company. In some places where the company already had telephones, additional instruments have had to be provided, and at places where they did not exist instruments have had to be installed in order to meet the demands of the traders, that means of communication being now generally resorted to in the course of business. In a number of cases this has incurred extra expense in the provision of staff to attend to the telephonc; and, while it is not overlooked that the company also obtain some benefits from the use of the telephones, there can be no doubt that the greater advantage is secured by the traders. To show to what extent the number of public telephones has increased during recent years, it may be stated that, whilc in 1904 there were II I 
connections serving the goods department, now there are over 400 .

Many traders have in recent years employed railway rates experts for the purpose of analysing railway rates and charges in order to obtain reductions in the figures, rebates in respect of terminals, and the re-classification of goods to a lower basis, and in this connection they have spared no pains in getting together information bearing upon matters about which they consider they have grievances; and representations have subsequently been made to the various Chambers of Commerce or other trade organisations. In their pursuits they have been encouraged by the open statement of the President of the Board of Trade that he is prepared to consider and deal with matters of this character, and by other members of Parliament interesting themselves in railway subjects. The publicity thus given to such matters has contributed to the greatly increased number of demands made for rebates and exceptional rates, and there has consequently been a large growth in the clerical work at the stations, and at district and chief offices.

Apart from the expense involved in the course of our own enquiries, a large amount of detail is requisitioned by the Board of Trade, entailing considerable cost to the company, as evidence of which it may be stated that in connection with the comparison made between English and German methods, representatives of this company had to be sent to Germany to obtain particulars of the practices adopted by the railways controlled by the Government there in order that the true state of affairs might be ascertained.

In order to illustrate, by actual figures, the smaller ratio of increased receipts to increased work on English railways under the conditions here described (and especially under the present- 


\section{Railways and Nationalisation.}

day tendency to eliminate the middleman, and do a direct trade, wherever possible), I give the following details respecting five railway depôts of different types :-

INCREASES IN 1906 OVER I 899.

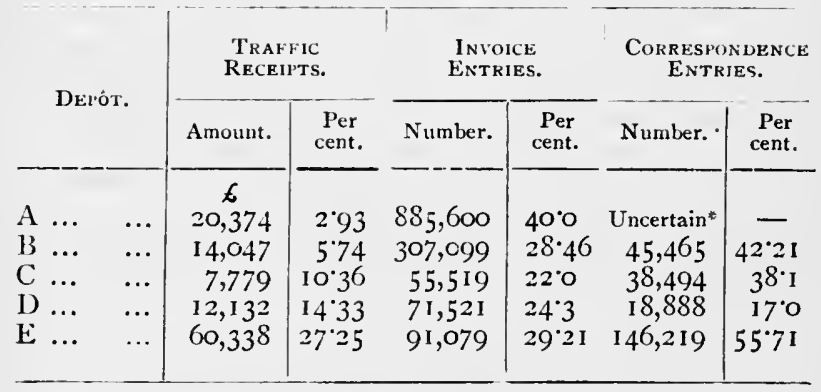

Different method of registration in 1906 than in 1899 : comparison not liable.

\section{TRADERS' GRIEVANCES.}

The sum total in 1906 of the invoice entries (representing different parcels or consignments) of which the increases are shown in this table was $5,438,000$. But these figures relate only to five depôts on the lines of a single English railway company. I leave persons endowed with greater imaginative or arithmetical powers than my own to estimate therefrom the possible grand total of the entries in regard to all the parcels, packages, and consignments in general entrusted to all the railway companies of the United Kingdom in the course of a single year. I con- 
British Railway position To-day. 385

tent myself with the suggestion that it would run into billions.

When I turn to the number of traders and others who--at the cost only of a penny postage stamp--have addressed formal complaints to the Board of Trade in respect either to these billions of separate transactions or to grievances in general against the railway companies, I find from a Return issued by the Board that during the two years, Ig04 and 1905, the total number of such complaints was only 146 ; while in regard to a certain proportion of the 59 cases in which no settlement could be reached the Return says " it seemed clear to the Board of Trade that the complainants had no real ground for complaint."

In point of fact, the people who have the most claim to cherish grievances concerning the railways to-day are, not the traders, whom the railway companies have spoiled rather than illserved, and not railway passengers, for whom so much in the way of clieap and confortable travel has been provided, but the shareholders who, though finding the money, have gained far less in proportion than either.

Admitting, however, that there are still various points connected with the relations between the traders and the railways which, though not warranting formal complaint to the Board of Trade or the Railway and Canal Commission, may call for inquiry and mutual con- 


\section{6}

Railways and Nationalisation.

sideration, it should be quite possible to arrive at some amicable arrangement or understanding thereon by means of friendly conferences, such as that of the Committee concerning which Mr. L.loyd-George said in the House of Commons on March $4^{\text {th, }}$ I908:-

The informal railway conference which is meeting at the Board of Trade is composed of representatives of railway companies, traders, agriculturists, the general public, and Government Departments. Its object is to endeavour to arrive at a general agreement with regard to such modifications of the existing law, and of the relations subsisting both among the companies and between the companies, traders, agriculturists, and the general public as may conduce to economy and elasticity of railway working, and also provides for the equitable apportionment of any advantages accruing therefrom. The conference has decided to appoint several subcommittees, consisting partly of its own members, partly of others, to consider and report to it on certain groups of questions, among which is the question of the conditions and procedure for working agreements, combinations, and amalgamations of railways, including any change in the relations between the railways and the State which might arise therefrom.

Those taking part in the conference are Mr. Hudson Kearley, M.P., Mr. H. Llewellyn Smith, C.B., and Mr. G. R. Askwith, of the Board of Trade; Sir F. Forbes Adam, C.I.E., Mr. A. Beasley, Mr. William Burton, Mr. A. Kaye Butterworth, Mr. Ratcliffe Ellis, Mr. S. Fay, Mr. IV. Guy Granet, Mr. James C. Inglis, Mr. IV. F. Jackson, Mr. O. D. Johnson, Sir 
W. T. Lewis, Mr. W. H. Mitchell, Mr. A. Mond, M.P., Mr. Ernest Moon, K.C., Sir C. J. Owens, Mr. A. Siemens, Mr. J. A. Spender.

\section{WAGES AND MATERIALS.}

It is a familiar story that the working expenses of railways have been considerably swollen of late years by reason of increased payments on account of wages and materials; but what this may mean in actual figures is not so well known. From a detailed statement published in The Railway News of April 4, 1908, giving the sums paid by leading companies during the half year for wages and materials in the maintenance of way, carriage and wagon, traffic and locomotive departments, as compared with the sums paid in the corresponding period of the previous year, I learn that the aggregate amounts paid for wages in the four departments mentioned was $\mathcal{E}_{\mathrm{I}} 4,856$, o0o, or $\notin 53 \mathrm{I}$, ooo increase; and for materials, $t_{4}, 538,000$, or $£ 309$,000 increase, a total increase on these two items alone for the half year of $\notin 840$,ooo. The significance of these figures becomes all the greater when one remembers that such increases have been steadily proceeding for quite a number of years.

Taking the wages paid in the traffic department of some of the leading railways, one learns that the increases in the last half-year of 1907 
over the totals for the last half-year of 1906 were as follows :-

\begin{tabular}{|c|c|c|c|c|c|}
\hline \multicolumn{4}{|c|}{ Company. } & INCREASE. & Per cent. \\
\hline $\begin{array}{l}\text { Great Central } \\
\text { Great Eastern } \\
\text { Great Northern } \\
\text { Great Western } \\
\text { Hull and Barnsley } \\
\text { Lancashire and Yo } \\
\text { London, Brighton } \\
\text { London and North } \\
\text { London and South } \\
\text { Midland ... } \\
\text { North Eastern }\end{array}$ & $\begin{array}{l}\ldots \\
\ldots \\
\ldots \\
\ldots \\
\ldots \\
\text { rks } \\
\text { and } \\
1-W \\
-W \\
\ldots \\
\ldots\end{array}$ & $\begin{array}{l}\ldots \\
\ldots \\
\ldots \\
\ldots \\
\ldots \\
\text { e. } \\
\text { Coast } \\
\text { ern } \\
\text { ern } \\
\ldots \\
\ldots\end{array}$ & $\begin{array}{l}\ldots \\
\ldots \\
\ldots \\
\ldots \\
\ldots \\
\ldots \\
\ldots \\
\ldots \\
\ldots \\
\ldots \\
\ldots\end{array}$ & $\begin{array}{r}\qquad \\
20,3 \text { I6 } \\
9,998 \\
11,997 \\
39,646 \\
6,909 \\
27,858 \\
3,013 \\
49,290 \\
8,752 \\
54,451 \\
27,978\end{array}$ & $\begin{array}{r}6.0 \\
2.5 \\
2.8 \\
5.1 \\
164 \\
5 \% 3 \\
1.6 \\
4.1 \\
2.6 \\
4.5 \\
4.0\end{array}$ \\
\hline
\end{tabular}

SAVINGS IN TRAIN MILEAGE.

It is mentioned that " in the case of the London and North-Western Company the increase in maintenance of way department of $\ell_{14}, 658$ was entirely owing to the sum spent on the strengthening of bridges rendered necessary owing to the heavier class of engines in use." Some years ago, it will be remembered, there was much talk in this country about American railway methods, and the British railway companies were criticised adversely for not having more powerful locomotives capable of drawing heavier loads, and thus saving train mileage. Many of the companies have since adopted more or less the practice in question, and one hears much as to the number of train miles saved in 
operation. But there is another side of the story, namely, the considerable amounts that have had to be spent on the extensive reconstruction or strengthening of bridges and the laving of heavier metals to bear the heavier engines and the heavier loads, so that the saving in train miles has been very far indeed from being all gain. It is even open to question whether, in some instances, there has yet been any gain at all.

\section{RAILWAY COMPANIES' COAL BILLS.}

To illustrate what the increased cost in materials may mean to a railway company, The Railway News mentions that in the half-year in question the Midland Railway Company spent $\$ 255$,000 on copper alone. Fxpenditure on the up-keep of carriage and wagon stock has increased, owing to the greater luxuries of travel; while the effect of advances in the price of coal (of which commodity the railway companies use over $16,000,000$ tons a year*) may be indicated by the case of the Caledonian Railway Company, whose coal bill (as Mr. Herbert Gladstone was informed by Sir Charles Renshaw, a member of a deputation which waited on the Home Secretary in March, 1908, in reference to the Miners' Eight Hours Bill) rose from $\mathcal{E}_{151,000}$ for the year ending January $3 \mathrm{I}$, 1898 , to 
$\$ 3,360,000$ in the year ending January $3 \mathrm{I}$, I908, the greater proportion of the increase being due to the higher price.

On this important subject of railway companies' coal bills, I take the following from "Chat on 'Change" in the Daily Mail of August 6, Ig08:-

As was the case in the second half of 1907 , the increase in the railway coal bills for the last six months explains fully half the reduction in profits. In the following table we compare the additional smounts paid for coal, with the total reduction in r)rofits for the last half-year in the case of the principal companies that have already issued their reports :-

\begin{tabular}{|c|c|c|}
\hline Company. & $\begin{array}{l}\text { ExTRA Cost } \\
\text { OF COAL. }\end{array}$ & \\
\hline Central & $.3^{88,60}$ & \\
\hline & & \\
\hline Nortl & 38,000 & $5^{1,0}$ \\
\hline IVe & 44,000 & \\
\hline 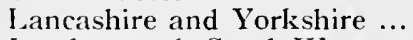 & & \\
\hline ern & n 34,000 & 42,000 \\
\hline B & 12,000 & ${ }_{15}, 000$ \\
\hline & d $\quad \mathrm{I}, 600$ & $I, 400$ \\
\hline $\mathrm{m}$ & m 21,500 & 79,800 \\
\hline
\end{tabular}

More than half the aggregate losses of these companies is thus accounted for, and in the instances of the Great Eastern, Great Northern, Great Western, South-lVestern, Brighton, and Tilbury companies it may be said that practically the whole of the reduction in profits was due to this item.

\section{WAGES AND WORK.}

Reverting to the question of wages, I would 
point out that while these have advanced the amount of work done for them has shown a steady tendency to decline. "WVe are getting as much out of five men to-day," said an authority on one of the leading lines, in the course of conversation on this subject, " as we got out of three men 15 years ago." More men thus have to be employed to do the same amount of work; though this, of course, is what the labour leaders desire, regardless of the effect on the earning powers of the companies. If the present demands for shorter hours should succeed, still more men will have to be put on, and the wages bill will then go still higher.

The usual plea for these shorter hours is, of course, that the men are working too hard. But, oddly enough, dentands for shorter hours are now being put forward by railway men in country districts on the ground that their work is monotonous because there is so little for them to do. This reason is especially pleaded by signalmen, of the onerous nature of whose duties so much is heard!

Concurrently with the falling off in the quantity of work done per man, the discipline of considerable sections of railway workers has been undermined by trade union influences. To give a case in point: There is a practice under which signalmen who do their work properly during the year are paid a bonus. On the least occasion when it is found necessary-on account 
of some mistake, for example-to suspend the bonus of a member of the Amalgamated Society of Railway Servants, the amount is made good to him out of the emergency fund of that society.

The combined effect of higher wages, shorter hours and less work will probably lead in the course of time to a greater resort by the railway companies-as a measure of self-defence-to labour-saving appliances, in order that their business can be conducted with fewer units. There are various possibilities in this direction, but meanwhile the growing wages list continues to be a most important item in the increase of working expenses.

THE BURDEN OF TAXATION.

Then there nust be taken into account the hampering effect on the railways of the enormous increase in the amount of taxation they are called upon to pay. Some remarkable figures bearing on this very essential consideration were given in a paper by $\mathrm{Mr}$. C. L. Edwards, chief accountant of the Great Northern Railway Company, read by him at a meeting of the Royal Statistical Society on March 17 , 1908. I will here content myself with reproducing from Mr. Edwards' paper two tables, of which the first gives a comparative summary of inland revenue and local taxation contributed by all the railways of the United Kingdom for the years I906 and I.89J; while the second shows 


\section{British Rallway Position To-day. 393}

the effect of local taxation on net revenue of the railway companies in the same period:-

COMPARATIVE SUMMARY OF TAXATION.

\begin{tabular}{|c|c|c|c|c|}
\hline - & 1906. & 1891. & Difference. & p.c. \\
\hline $\begin{array}{c}\text { I } \\
\text { Inland revenue : } \\
\text { Passenger tax } \\
\text { Income tax }\end{array}$ & $\begin{array}{c}\underset{\sigma}{6}, 642 \\
356,600 \\
2,062,090\end{array}$ & 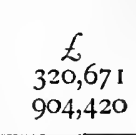 & $\begin{array}{c}\quad t \\
+\quad 35,971 \\
+1,157,670\end{array}$ & $\begin{array}{r}I I \\
+128\end{array}$ \\
\hline$\stackrel{2}{2}$ Local taxation* & $\begin{array}{l}2,418,732 \\
4,954,636\end{array}$ & $\begin{array}{l}I, 225,091 \\
2,246,430\end{array}$ & $\begin{array}{l}+1,193,641 \\
+2,718,206\end{array}$ & $\begin{array}{r}97 \\
121\end{array}$ \\
\hline Total. & $7,383,368$ & $3,47 \mathrm{I}, 52 \mathrm{I}$ & $+3,911,847$ & 113 \\
\hline
\end{tabular}

EFFECT OF LOCAL TAXATION ON NET REVENUE OF RAILWAY COMPANIES.

\begin{tabular}{|c|c|c|c|c|c|}
\hline \multicolumn{3}{|c|}{$\begin{array}{l}\text { Perchintage of Local Taxation } \\
\text { to Gross Receipts. }\end{array}$} & \multicolumn{3}{|c|}{$\begin{array}{l}\text { Percentage of Net Revenue on } \\
\text { Total. Pail-up Capital. }\end{array}$} \\
\hline 1906. & 1891. & Difference. & 1906. & 1891. & Difference. \\
\hline $\begin{array}{c}\text { Per cent. } \\
4^{-24}\end{array}$ & $\begin{array}{l}\text { Per cent. } \\
274\end{array}$ & $\begin{array}{l}\text { Per cent. } \\
+I^{\prime} 50\end{array}$ & $\begin{array}{l}\text { Per cent. } \\
\quad 3.45\end{array}$ & $\begin{array}{c}\text { Per cent. } \\
3.87\end{array}$ & $\begin{array}{l}\text { Per cent. } \\
-0^{*} 42\end{array}$ \\
\hline
\end{tabular}

Mr. Edwards also pointed out that if the percentage of local taxation had been the same in 1906 as in $189 \mathrm{I}$, the net receipts would have been $\mathscr{E}_{1,752,59 \mathrm{I}}$ more, and the percentage of net revenue on total paid-up capital would have been $3 \cdot 59$ per cent. instead of 3.45 per cent.

* I have already shown, on page 111 , that the amount of local taxation paid by the Prussian State railways (with whose rates those charged on British lines are often compared) is only $£ 750,000$ a year. 


\section{THE NEED FOR ACTION.}

While the working expenses of the railways have been increasing in the way described, and while traders, passengers, workers, and local authorities have all been gaining at the expense of the railway shareholder, the railway revenue has further shown a falling off, due to decline in trade, competition of suburban tranways, onnibuses, motor cars, etc. In the result the margin between receipts and expenditure has become exceedingly small in the case of some of the companies, and threatens to become still less.

The general outcome of the situation was well summed up by two tables given in the City article of The Times of August 15, 1908. One of these set out the gross receipts, expenditure and net revenue of eleven railway companiesGreat Central, Great Eastern, Great Northern, Great Western, Lancashire and Yorkshire, London, Brighton and South Coast, London and North-Western, London and SouthIVestern, Midland, North-Eastern, and SouthEastern and London, Chatham and Dover-for the half-years ended June 30,1908 and 1907 , showing a total decline of $£ 521,000$ in receipts, an increase of $£ 667,000$ in expenditure, and a consequent decrease in net revenue of no less than $\mathcal{E} \mathrm{i}, \mathrm{I} 88$,

The other table gave, for the same companies, 
the rates of dividends and amounts paid as dividends on ordinary stocks, with amounts carried forward. In ten cases (reckoning, here, the SouthEastern and the London, Chatham and Dover as separate companies) there was a reduction in the rate of dividend paid in 1908 as compared with 1907; in one (Great Central) no dividend was paid in either year; and in the case of the Great Northern the same amount as before, 3 per cent., was paid, but at the cost of a substantial reduction in the amount carried forward, which stands at $£ 6,549$, as against $£ 61,646$.

Beyond, however, the question of the moment, there is the question as to what will be the position so years hence of the companies which have been the most heavily hit. They cannot go on indefinitely as they are, and the time mav well come when, unless the State should buy them out (a procedure which would be eminently satisfactory to shareholders with no dividend at all in sight), the only alternatives will be either to stop working altogether or to increase fares, rates and charges.

In the United States the railway position has become so unsatisfactory that the companies there are now face to face with the problem whether they shall advance the railroad rates ro per cent. or decrease wages io per cent. If they advance rates all round they will come in collision with the Interstate Commerce Commission, which has already given warning, by 
a formal statement issued at the end of July, 1908 , that " if the tariffs which by law the railways are bound to file in Washington 30 days before a new rate goes into operation show a general increase, the Commission will use its almost unbounded powers of investigation without waiting for representation on the part of the shipper." "Then," adds the official warning, " if any complaint arises, it will be able to act very promptly." If, on the other hand, they reduce wages, the companies will bring around their head a hornet's nest not only of labour but also of political troubles.

Leaving, however, the American railways to solve their own problems, the question of the moment here is how the British railway companies are to keep down their working expenses in order both to meet the increasing demands made upon them and to make a better return to the individual who is the person chiefly aggrieved by present conditions, namely, the railway shareholder.

THE SOLUTION OF THE PROBLEM.

The most practical way in which-if they are allowed-the British railway companies can work out their own salvation will be in a further resort to their policy of combinations, alliances, or agreements. Here, if they are given fair play and a reasonable opportunity to operate commercial enterprises on commercial principles, 
British Railway Position To-may. 397

they have facilities open to them in many ways for reducing their working expenses.

There would not be quite so great a saving as many people assume from the suppression of "duplicate services," because one has to consider not merely the persons travelling by trains between London and, say, Manchester, Exeter, or Scotland, by different companies' lines, but, also, passengers who would join or leave the trains at intermediate stations. If the big cities alone are considered, and a very material reduction is made in the rail facilities of towns of second or third rate rank situate on a competing route, but served by one company only, the new state of things would create grievances far more serious than anything that is suggested now. The trains mainly concerned, therefore, are those of the through express or non-stop type.

There would be possibilities of considerable savings in regard to management, joint in place of separate receiving offices, joint use of rolling stock, better loading of goods wagons, the use of a larger number of such wagons, the running of trains by alternative routes in order both to shorten distance and to relieve the congestion of crowded lines, direct consignment of goods under a unified management instead of there being dealings with or between different companies; in these and in other ways economies could be effected without prejudicing the interests of the public, who would, indeed, have 
increased facilities in the use of tickets over different companies' lines, the advantage of the shortest routes in forwarding consignments, and other benefits besides.

TIIE PROPOSED GREAT NORTHERN, GREAT CENTRAI. AND GREAT EASTERN ARRANGEMENT.

All these considerations are certainly to be found in the proposed working agreement between the Great Northern, the Great Central and the Great Eastern Railways Companies, for which the assent of Parliament is to be asked in the Session of rgog. Already, among other things, the three companies have arranged to have their receiving offices in common, to have joint carting arrangements, to discontinue some duplicate services, and to make return and certain season tickets available by either company's line.

But there are various other measures contemplated by the companies for which, on account, in their case, of purely technical reasons (as the Great Northern and the Great Central found when they tried in 1908 to effect a dual arrangement through the Railway and Canal Commissioners) the assent of Parliament is necessary,

* The Railway and Canal Commissioners held that the Act of 1858 , which authorised the Great Northern and the Manchester, Sheffield and Lincolnshire (now the Great Central) Railway Companies to enter into a working agreement, applied only to that part of the Great Central undertaking which was in existence in 
and the advantage to all concerned of some of these further reforms is beyond dispute. Thus, should the working agreement be approved by Parliament, fish sent from Grimsby to London by the Great Central would go to the Great Northern company's Mint Street depôt, which is close to Billingsgate market, instead of being carried first to Marylebone Station (the only London depôt of the Great Central Railway Company), and thence carted through the streets of London to Billingsgate, a distance of about four miles. By the new arrangement this expense of cartage will be saved, and the fish should arrive at Billingsgate earlier, if not, also, in better condition. In the same way fish from Yarmouth or I.owestoft, on the Great Eastern Railway, for the same market, would be delivered there from the Great Northern Mint Street depôt, instead of being carted from the Great Eastern depôt at Bishopsgate.

Then the residents in the great manufacturing districts served by the Great Northern and the Great Central systems will obtain better access to the seaside resorts of Norfolk and Suffolk served by the Great Eastern; colliery owners and traders in general in the former districts will

${ }^{1} S_{5} 8$, and not to the company's extension to London. A fresh Act must therefore be obtained, and it is proposed that the new arrangement shall include not only the two companies mentioned, but the Great Eastern as well. 
have opportunities, by means of quicker and more direct services, for developing their business in the Eastern Counties, and for getting into closer connection with the London Docks, while the possibilities to traders in either north or east of dealing with a combined management, in questions of through rates, instead of with two or even three separate companies, cannot fail (1) be appreciated.

How the position is regarded from the standpoint of the railways concerned is shown by the following remarks by the chairman of the Great Eastern Railway Company, Lord Claud Ilamilton, at the half-yearly meeting of the shareholders on July 31, I908:-

The one event in the past half year which no doubt mainly interested you, and which will have a very important bearing upon your prospects in the future, was the official announcement that this company had decided upon an alliance with the Great Northern and Great Central companics with a view to closer working in a spirit of harmony, and the avoidance of that class of competition which, whilst proving of no real benefit to the public, injuriously affected the net receipts of all three companies. I have long hoped for some such arrangement, and the experience of the past two or three years has conclusively proved that without it the financial position of the three companies in question could hardly be expected to improve, but, on the contrary, might deteriorate. All three companies are in varying degrees suffering from a diminution of traffic, increases in cost of materials, and there has been a steady rise in wages. $\mathrm{We}$, and no doubt the other two companies, have all 
practised the strictest economy and concentrated the attention of our respective boards and officers upon the all-important question of more economical working on every part of our systems, subject to the maintenance of efficiency and the safety of the travelling public. But in spite of our efforts the difficulties we have had to face have been so strong that we were called upon to consider some other method of attaining our end. I believe the one resolved on will commend itself to the shareholders of the three respective companies, for when it is carried through it cannot fail to prove of material advantage to them. What we shall ask Parliament to sanction is a closer community of interests between the three companies in the form of closer working on the lines of the agreement between the Great Northern and Great Central companies, the discontinuance of that competition which, whilst, in fact, profitable to none, has been a loss to all, and a gradual rearrangement as opportunities occur of our passenger services and goods arrangements, whilst offering to the public increased conveniences and greater facilities for rapid and more direct through transit over the joint system than can ever be obtained over the three systems under present conditions.

The chairman of the Great Central Company, Sir Alexander Henderson, speaking at the halfyearly meeting of that company on August $;$; 1908, said, concerning the proposed alliance:-

The competition that has prevailed for so long has not been of any real benefit to the public, and has certainly injuriously affected the net receipts of the three companies. Notwithstanding the exercise of great economy, we are all finding a decrease in our net revenue, and it is essential we should find some method whereby our shareholders should reap some reward for their expenditure.... Of course we 
may not be successful in our appeal to Parliament, but, whatever happens, the status quo ante is an impossibility. . . . We can but hope that the period of distrust and suspicion is past, and a new order of things has taken its place.

Then, again, Lord Allerton, chairmau of the Great Northern, in dealing with the same matter at the half-yearly meeting of that company on August I I, 1908, said :-

Any one who knew of the associations and connexions between the Great Northern and the Great Central companies-the equal ownership of joint lines and the working over one another's lines, to a certain extent, of traffic in its passage from point to point-would be aware that the same conditions applied with respect to the Great Eastern Railway; and the possibilities for improved working, improved service to the public, and effective economy would be greater by putting the three companies together than by putting the two companies together.

After quoting from Mr. Asquith's speech at Manchester the remarks I have already given on pp. 377-8, I,ord Allerton proceeded :-

If that indictment had been made against the directors by a shareholder in that room, it would have been regarded as very strong; but it was their case. He believed that there was enormous waste, and wherever there was enormous waste it was a national loss. He might mention two matters in which he was convinced that great savings might be effected. Did the shareholders know that the cost of collection and delivery to the three companies represented $£ 800$, ooo a year, and that in many cases three vans went over the same ground canvassing for the same goods? Then, he found that the 
number of train miles per day which they were at present getting out of a driver and his engine was less than 6o; putting it in other words, it was 354 miles in the particular week for which he examined the figures, and he supposed that that might be divided by six at least. He had not a doubt that if the proposed agreement were sanctioned by Parliament, they might, by rearranging their working, enable the engine to project itself a trifle further every day. That would be a saving of money to them, and an advantage in punctuality and delivery to the traders and the service. . . . It was sometimes said that by putting the railways together there would be a monopoly, as it was called, in the districts affected, and that the companies would behave hadly; but the whole railway history of this country was in direct conflict with that view. One could not point to a single small railway which had been absorbed by a large one and which had been worked by the latter, in which there had not been an immediate improvement in the service of the district. It could not be otherwise. That was all that the three companies were asking for in the arrangements they proposed.

It is difficult to see what hidden dangers to the community there can be in such very practical and common-sense arrangements as these, and it is to be hoped that Parliament will, in the circumstances, allay its time-honoured suspicions of railway agreements, that local authorities and trading or other organisations will on this occasion be restrained from levying blackmail, or at least from imposing merciless exactions, as the "price" of their assent, and that the way will be opened out for still more 
404 Railuays and Nationalisation.

of such arrangements, in the interests, not alone of the companies and of their shareholders, but also of the country in general.

EXISTING POWERS OF ARRANGEMENT.

The reference already made on p. 379 to the arrangement between the London and NorthIVestern and the Lancashire and Yorkshire companies, which came into force in 1905, shows that there are agreements railway companies can carry out between themselves without seeking the Parliamentary sanction that appears to be necessary in the particular case of the triple alliance just mentioned. Railway companies are, in fact, already able to make arrangements one with another, on certain specified points, within the range of their existing powers, and to the advantage alike of the public and of the shareholders. They can, for instance, agree that tickets issued by one company shall be available for use over the lines of another company, so saving competitive trains and at the same time benefiting their patrons. They can agree to have receiving offices in common: which means that where two of such offices, owned by different companies, are close together, one can be done away with and rent and wages saved. This might be an important consideration in a city where land and property are of great value and many of such offices exist; while, where, in the case of a suburb or a country town, only one 
British Railway Position 'To-day. 405

company has a receiving and inquiry office, the single office would receive parcels, issue tickets, collect advance luggage, or transact other business for both, additional conveniences being thus also conferred on the local residents. In the same way there can be common use of either company's stations, town offices, etc.

Two companies can agree that the vans owned by either of them shall collect for both. This will allow of a certain number of vehicles, horses, and drivers being dispensed with. It should be of advantage to the trader, who will be able to give to the van-man of one company goods to be carried by another company, and will find his premises less blocked by vans, since there will no longer be the same necessity for so many to call, It should, again, afford some relief to the street traffic in large cities, inasmuch as fewer vans will require either to stand in front of warehouses, while being loaded up, or to obstruct other vehicles still further by their slow rate of progress through the streets. Here, in itself, is an important consideration both for city authorities, faced with the grave problem of dealing effectively with the ever-increasing street traffic, and for motorists, to whom railway lorries in town must often be still more annoying than farmers' wagons in the country; so that railway companies ought to secure for their present policy the commendation of these two classes at least. 
Companies can further agree between themselves, within the limit of existing powers, that each will carry by the shortest route goods entrusted to another to deliver. This means, for the companies, a more economical loading of wagons (which now too often go only half or a quarter full), and the possible saving of certain of the goods trains; and, for the trader, a still quicker transport tor his consignments (when these are now taken by a long route and a short one is available) and, especially, a still greater guarantee of early delivery to the shopkeeper who replenishes his stock from day to day (more or less) and to whom the difference of even an hour or two in the arrival of fresh supplies in the morning may be of material concern.

LONDON IND NORTH WESTERN AND LANCASHIRE AND YORKSHIRE ARRANGEMENT.

It was on such lines as these that the London and North-Western and the Lancashire and Yorkshire companies made their friendly arrangement, without requiring to ask Parliamentary sanction; and, although at first there was the inevitable outcry, it was speedily found that, while the shareholders would gain by the taking off of duplicate trains and by the other economies mentioned, the traders and the public, would also benefit through the concession to them of the increased facilities.

The position from the railway standpoint was 
well summed up by the chairman of the London and North-Western Company, Lord Stalbridge, when he said, at the half-yearly meeting of that company on February i 7, 1905 :--

Had not both sides been reasonable and determined to exhaust every effort in coming to an understanding, the two companies might easily have been involved in a ruinous competition, entailing large capital outlay as well as greatly increased expenses.

THE LONDON AND NORTH-WES'TERN AND MIDLANI) ALLIANCE.

The policy thus indicated has also been followed up in another direction. At the halfyearly meeting of the London and NorthWestern Company in February, 1906, Lord Stalbridge said :-

We are quietly, continuously, and, to an extent, successfully doing all we can to promote co-operation between companies, in order to avoid wasteful competition. We may fail at first to carry through what we may consider would be to the advantage of the companies concerned; but that is not surprising, when you think of the enormous and conflicting interests involved. That, however, does not dishearten us or deter us from continuing our efforts. One important agreement in this direction that we made with the Lancashire and Yorkshire Railway Company has been most beneficial to both companies; uscless competition has been put an end to, considerable economies have been effected in working, and heavy expenditure on capital account has been avoided. We have also been able to give increased facilities to the public. We have arrange- 


\section{Railways and Nationalisation.}

ments, with the same end in view, with other companies, notably with our principal competitor-the Midland-and I have every reason to believe that, where it is possible and in the interests of the shareholders, the Midland and North-Western will extend such co-operation.

A like announcement was made by the chairman of the Midland Company, Sir Ernest Paget, who, at the half-yearly meeting of the shareholders of that company held in the same month of 1906, said :-

IVe have made arrangements with the NorthWestern which will tend to the economical working of both companies, and greatly to their advantage. And, further than that, I am glad to say the NorthWestern Company have taken this matter up very seriously with a view to getting competing companies more together, and so avoid unnecessary expenditure. I am afraid that the North-Western Company have not received altogether the support that we could wish; at the same time, we hope that they will not be discouraged, and Lord Stalbridge told me they would not be discouraged; but I am quite sure, if they go on in this direction, they will succeed in the end, and, further, I am quite sure of this, that my colleagues and I will do all in our power to further that end.

Sir Ernest Paget reverted to the same subject at the meeting of his company in February, I 908 , saying :-

The result of the arrangement which has been made is very satisfactory indeed, and I hope we shall go on and make further arrangements.

These further arrangements in the interest of 
economies were duly made, and on August 6, I9o8, there came the official intimation that :-

The London and North-Western and Midland companies have arrived at an arrangement of a comprehensive character to endure for a long period of years which will, it is hoped, be the means of enabling considerable economies in working expenses to be effected, while, at the same time, the public will obtain the advantage of increased facilities for passenger and merchandise traffic.

The more comprehensive arrangement here indicated is thus the outcome of earlier tentative efforts, which prepared the way, and demonstrated the practicability of the larger design now resolved upon. The more recent departure (for which, it seems, there is again no need to seek for Parliamentary sanction) is thus to be regarded as the evolution of a scheme well thought out, and already well tested, rather than an expedient hastily adopted by reason of the recent activity of the nationalisation party. It is desirable that this fact should be clearly understood, because there are members of the said party who would have the world believe that it is their own action which has led the various railway companies concerned to take the course they are now adopting.

All the advantages, both to companies and to the public, already spoken of in connection with the agreement of the London and North-Western and the Lancashire and Yorkshire companies 
will be repeated, though on a still larger scale, by the arrangement between the London and North-Western and the Midland. Considerations as to through passenger train services and carriages, interchangeability of tickets, luggage in advance to be collected by one company and delivered from a station belonging to the other, joint receiving offices, carriage of consignments by the shortest routes, and so on, arise in even greater force in the one case than in that of the other, the Midland being a line with extremely widespread ramifications, while the I ancashire and Yorkshire operates in a more limited area. The London and North-Western and the Midland systems are, in fact, eminently adapted to such an arrangement as that proposed. "The geographical positions of the two companies," said Lord Stalbridge, at the halfyearly meeting of the London and NorthWestern Railway Company on August I4, I9o8, "are such as to place them in competition for traffic between many important places "; and he proceeded :-

We have long desired to arrive at a means of so combining the interests of the two companies as to cnable the traffic in which both are interested to be carried on with thorough efficiency united with the greatest economy, consistent with that efficiency, in the common interest of both companies. Many arrangements have been made with our Midland friends with this object, but they have hitherto, though important, been relatively of a minor char- 
acter. Now, however, I am glad to say that we have been able to make an agreement which will, we hope and believe, have very important results. Its principles are, first, the elimination of all inducements to excessive competition, which, while expensive, produce no additional traffic; and, second, co-operation in the working of all competitive traffic in the manner most convenient to the public and most economical to both companies. These being the principles, the mode of application is the division of receipts from competitive traffic in certain proportions based upon the actual carryings of the two companies over a given period in the past. It cannot be otherwise than a gradual business to ascertain where, and in what ways, the working of the traffic can be improved and economised. This work, however, is in progress, and the inducement to the abstention from expensive competition is in full force, because the settlement of accounts, when necessary figures have been ascertained, takes effect from the Ist July last. You may be sure that we shall lose no opportunity of extending the arrangement, to the advantage alike of the public and of the shareholders, applying, if necessary, to Parliament for further powers.

Replying to a shareholder, Lord Stalbridge stated that the combination with the Midland company was to continue till I999.

Sir Ernest Paget informed the shareholders of the Midland company at their half-yearly meeting on the same day that the arrangements made were "for the pooling of all competitive traffics." He added :-

This would eliminate unnecessary competition, while also conducing to the better operation of both their lines, which would undoubtedly result in large 
economies. Those economies had always been most desirable, but never more so than now. The principle of the arrangement was the pooling of the whole of the traffic, and the division of the receipts according to the ratio of past earnings. An arrangement of that kind could not be popular unless there was some advantage to the public, and he felt sure that the facilities which the railway companies would be able to give to the travelling public and to traders generally would very completely allay any anxiety or fear as to the arrangement which might exist in certain quarters, but which he believed would prove to be absolutely and entirely unfounded.

SOME POSSIBLE DIFFICILTIES.

While, however, the principle of alliances and arrangements such as those here in question is undeniably sound, and appears to offer the best solution to the railway problems of the day, there are certain difficulties which are not to be overlooked in regard to the general application of the principle in question.

Among other consequences of the policy pursued by Parliament for so many years in encouraging active competition between companies must be reckoned a very great compliration of railway interests, especially in regard to running powers, routes, exchange of traffic, etc., so that, although working agreements may be brought forward which are perfectly fair to the parties directly concerned, there is always the possibility that some other company outside the proposed new agreement may consider that its 
own interests are threatened by (say) a possible diversion of traffic which it has hitherto handled.

The ramifications and complications of the British railway system are thus almost interminable, and the first phase of the great educational work which must be carried out to ensure the most economical methods of operating the lines, under more or less combined working, applies to the railway companies themselves, inasmuch as it is for them to consider in what way improvements can be effected in on . direction without causing injury, or interfering unduly with rights or reasonable expectations, in another. Delicate situations may thus arise, but, under a policy of give and take and of considerations for the general good, they ought not to be so far unsurmountable as to lead the nationalisers to suggest that the best solution after all would be for the Government to take over the lot. There is the greater reason why the one alternative is better than the other, because effective co-ordination among the companies should afford most of the advantages that could be derived from nationalisation, without the risk of those drawbacks of State ownership and State operation which I have already detailed.

On the other hand the existence of possible difficulties of the type here indicated has had far less to do with restraining companies from seeking to enter into more of these alliances than 
414 Ralliays and Nationalisation.

their reluctance to expose themselves to the denunciations and attacks which hitherto have invariably followed the announcement of any such proposals.

ATTITUDE OF PARLIAMENT.

The next step will be to try to convert Parliament from the old fallacy that keen competition . between railway companies, regardless of the consequences to themselves, is essential to the welfare of the conmunity. We have the most striking proof already that competition carried to excess, under the auspices, if not at the direct instigation, of Parliament, finishes off by being actually harmful to the community, since a point is reached when not only are the shareholders prejudiced, but the railway companies themselves are checked alike in their enterprise and in their power to make concessions to traders and others.

It is impossible now to retrace steps already taken, and, on account of the complications mentioned above, there may be some difficulty in rquitably dividing the United Kingdom intu different districts, in which each railway company, or group of unified companies, would have its own sphere of operation, as was done years ago under the practical and common-sense scheme carried out in France. But it might, at least, be suggested that when British railway experts-who are confessedly among the most 
British Rallway Position To-day. 4I5

competent of their class to be found in any country in the world-ask support for schenes which are aimed, not at getting any unfair advantage over the public, but at placing their lines on a sounder financial basis, Parliament should regard such proposals with more sympathy and less suspicion and prejudice, and should also assure to the railway companies ampler protection from any possible selfishness and unreasonableness-if not even actual rapacity-on the part of local interests.

\section{THE EDUCATION OF THE PUBLIC.}

The third phase of the policy here recommended is the need for bringing home to the mind of the community in general the fact that amalgamations, combinations and working agreements between railway companies, aimed directly at a more economical operation of their lines, must be to the direct advantage of the public themselves, since it will add strength to the railway position, allow the companies to check waste, and enable them to give better terms or increased facilities to their patrons.

Prejudices against railway companies live long and die hard. It seems to be of little use to point to what British railway companies-not only, as I have shown, without State aid, but in spite of persistent State obstruction and State handicapping in many different ways--have done to promote trade and travel and to add to the 
enjoyment of the public. It is almost futile to recall the fact that in no country in the world has the trader been really better served by the railways than in the United Kingdom; that in no other land have travellers received more consideration in the way of third-class accommodation in express trains, with well-lighted and wellventilated corridor carriages on bogey frames, refreshment cars, and every possible comfort and convenience for a long journey. All these things, together with the multiplicity of chear excursions, tourist tickets, week-end trips, etc., are apt to be forgotten, or taken for granted without an atom of gratitude or appreciation, by the average Englishman when it is a matter of indulging in the favourite sport-almost as popular as golf itself-of grumbling at the railways. Yet the aforesaid average Englishman must see that the railways of his country cannot all go on as they are, and that it will be more prudent on his part to give them sympathetic encouragement in any reasonable reorganisation of their position they may seek to make, by means of friendly arrangements based on business lines, than to favour a resort to what would be, in the case of the United Kingdom, an essentially quixotic scheme of State purchase and State operation.

DISTRUST OF RAILWAY COMBINATIONS.

The fears that the welfare of the traders especi- 
ally will be endangered by railway combinations are mainly imaginary. Such combinations, as we find, have been proceeding since the early days of railway history, and no prejudice to the commerce and industry of the country, but rather substantial gain thereto, has resulted from the amalgamation of groups of fifty, sixty or even a hundred small companies into a great one. With each amalgamation thus effected there has already been a decrease in competition, and the trade of the country has not yet been ruined by the railways, nor have the railway companies become all-powerful monopolists, accumulating unbounded wealth at the expense of the country.

Should the same combination policy undergo further development, the traders would still be fully protected by Parliamentary enactments which not only compel the companies to keep their rates within stipulated maxima, but, as I have shown before, make them liable to be called upon to justify their action if they even increase the rates beyond the amounts at which these now stand. If, to meet the new developments (which will naturally be closely watched), it should be found necessary to strengthen the existing powers of Parliamentary control over the railways in the interests of the traders or of the community ; or if it should be found desirable to afford still greater facilities to the traders in the representation of their wishes or their grievances, there should be no great difficulty in the way of Parliament taking action accordingly, 
4 I8 Railways and Nationalisation.

and assuring any further guarantees the altered situation might really require.

\section{A RAIL WAY “ TRUST.”}

These considerations are especially to be remembered when the question arises-as it probably will-whether the alliances now proceeding or projected may not lead to the creation of a railway "trust." Any uneasiness in this direction is probably based on the experiences of the United States; but the railway conditions in that country are altogether different from our own. Built originally in a very primitive way, and given at first an exceptional degree of freedom and independence, the American railways developed abuses, or were themselves subjected to abuses, in regard to transport, which would be impossible under the far stricter control exercised over the British lines; while the fact that the holding of railway shares in the United Kingdom is spread over so large a number of persons-of whom a great proportion seek a safe investment rather than have any wish to speculate-decreases the risk of British railways becoming the sport of financiers to the same extent as is the case with $\Lambda$ merican railways.

Bearing in mind the strong hold which Parliament, under any possible conditions, will still be able to exercise over consolidated or allied railway systems here, I should say that the comparison would be far less with Anierican "trusts" than with those great French railway companies 
who divide France between them, and, in the circumstances, have a monopoly and a freedom from competition far greater than could now be effected through any practicable railway combinations in the United Kingdom. So far as I am aware, there is no suggestion that these French companies-themselves subject to strict Government control-either abuse their powers or avail themselves of the absence of competition to overcharge, or to neglect the interests of, the populations they are expected to serve. On the contrary, the fact that they do not have to waste alike their resources and their energies on con!petition of the "cut-throat" kind renders them better able to cater for the wants and requirements of the particular territories assigned to them.

SCOPE FOR REASSURANCE.

The British public should, in fact, satisfy themselves that, with a further decline in the extent or in the keenness of railway competition, the companies, while effecting useful economies, will not either abandon their forward progressive policy-which it is to their own advantage they should maintain-or take any undue advantage of the trader, from whose increased prosperity they: will themselves directly benefit.

There is no ground for suggesting that the virtual monopoly already enioyed by the NorthEastern Railway Company in a considerable 
portion of its district has been detrimentai to the commercial welfare of that part of England. Nor, I am sure, has Cornwall suffered in any way because of the supremacy there of the Great Western Railway. On the contrary, where one company has a district to itself, it is all the more concerned in helping to bring about therein a substantial commercial and industrial expansion, the benefits of which---from a railway standpoint-would not have to be shared with a competitor.

The soundness of the policy here advocated is thus confirmed by experience past and present, and, in giving it their cordial support, traders and the public will find they have nothing to lose but much to gain from adopting a more sympathetic attitude towards the railways and rendering what help they can in placing the railway position in general on a firmer and more prosperous basis.

Even, however, when this attitude has been adopted, and this help given, the path of the companies will be by no means smooth, for they will still have to reckon (as the State itself would do, if it bought them out) with that heavy capitai expenditure-due to causes described in earlier chapters-which, greater far than in the case of other systems of railways elsewhere, must always leave them at a disadvantage that no possible combination or co-ordination can fully surmount. 


\section{CHAPTER XVII.}

\section{SUMMARY AND RECOMMENDATIONS.}

THE survey of railway nationalisation in practice, as given in the present volume, establishes, I consider, certain distinct propositions, the more important of which I would summarise as follows :-

(I) Railways may be either constructed or acquired by a State, and may then be either operated by the State itself or transferred to private companies; these distinctions and differences showing that the phrase "railway nationalisation" is open to various interpretations, and that specific definitions are essential.

(2) State construction of railways may be fully warranted, and even deserving of high commendation, in lands where new country has to be opened up for settlement, where population and financial resources are alike limited, and where private enterprise is unequal to so costly and, it may be, so speculative an undertaking.

(3) State purchase of railways may be equally unavoidable and equally expedient in lands where private enterprise has resulted in failure, or where material considerations of national 
defence, protective policy, State finance, or international relations are directly concerned.

(4) Accepting propositions (2) and (3) as applying to various foreign countries and British colonies, it does not necessarily follow that the same reasons would in themselves justify either State construction or State purchase of railways in the United Kingdom, where an almost complete network of railways (but for a few desirable connecting links, branch lines, and widenings) already exists, rendering State construction unnecessary; where the factors mentioned as justifying purchase would not apply; where private enterprise in both construction and operation has been equal to all reasonable requirements for three-quarters of a century; where the question of purchase price would be greatly complicated $(a)$ by the overcapitalisation of many of the lines, owing, in part, to State policy in the past; $(b)$ by the deadweight of unremunerative capital, for which allowance must be made and the burden of which must be assumed; and $(c)$ by the many Kubsidiary enterprises now forming an essential part of railway ownership and operation; and finally, where the sum total of the purchase money would be prodigiously large, the prospect of material gain most uncertain, and the probability of serious interference with the national finances beyond the shadow of a doubt.

(5) State operation of railways elsf where has 
not been shown to be more economical, more eficicient, and better for traders and travellers (especially those of the third class) than operation by companies at home; whereas we have distinct evidence that State operation may involve $(a)$ deliberate presentation of the railway accounts in an unduly favourable light, in order to convey a wrong impression to the taxpayers; (b) the introduction into railway administration of political influences which render impossible operation on ordinary business lines, encourage deep-seated and widespread corruption, and tend to degrade the character and mar the efficiency of the national or colonial Parliament; (c) serious evils in the creation of a large body of State servants, who may provoke grave labour troubles, or, as elector employés, may either themselves use their political privileges to their personal advantage, or, alternatively, be made use of by Governments or Parliamentary candidates to serve their own particular end, bribes being thus offered, or pledges being thus given, the fulfilment of which would be prejudicial both to railway and to national interests; and $(d)$ a possibility that the desire of the railway companies to secure a reasonable return on invested capital may be superseded by a much more active endeavour on the part of a Finance Minister to obtain large contributions from the railway revenue for the national exchequer.

(6) That even where State ownership of rail- 


\section{Railways and Nationalisation.}

ways has been necessarily or justifiably adopted, such disadvantages and dangers as those mentioned in proposition (5), and others besides, would be avoided by the State entrusting the actual operation of the lines, under suitable conditions, to private companies.*

(7) That, inasmuch as the real function of a Government is to govern, it is better that a Government should (where this is practicable) be content to control railways rather than to own and operate them.

(8) That the operation of railways by commercial companies, under such effective control by the State as is already enforced in the United

* Supplementing what I have already said on this point in connection with Holland, Mexico and India (pp. 6-8), and Belgium (p. 249), I might here mention that in the last-named country the provision of an extensive systen of light railways (the building of more main lines of railway there having practically ceased) has been undertaken, since I 885 , by the "Société Nationale des Chemins de Fer Vicinaux," the shares in which are held almost exclusively by the State, the provinces and the communes. The Society has a monopoly of the construction of these light railways, but it has renounced exploitation, and prefers to transfer the operation of them to private companies, in order, according to M. Colson, the eminent French authority on railways, " to avoid the intrusion of politics." ("Transports et Tarifs," 3 rd edition, p. 777). The operation of I3 8 lines of these light railways, now open, with a total length of about I, 860 miles, has thus been divided by the Society between 37 different companies. (For details as to the origin, development and present position of the Belgian light railways system, see an article on "Nos Chemins de Fer Vicinaux," by M. C. de Burlet, in the "Revue Economique Internationale", (Brussels), I5-20 Février, 1907.) 
Kingdom in regard to construction, working, safety, rates and charges, etc., is far better for traders and the community, inasmuch as it ensures adequate protection of the public interests; is more elastic; is more free from the red-tape and routine characteristic of State departments; is in closer and more sympathetic touch with those interests of trade and commerce which are also the interests of a railway company; and is more likely to offer greater facilities in the way of excursions, cheap fares, and comfortable travel.

(9) That various sections of the party favouring nationalisation of the British railways are inspired far less by considerations for traders, travellers, and the large body of railway shareholders than by socialistic views, personal interests, and motives of political expediency.

(Io) That the direct association of the railway system with the machinery of party politics would in itself be prejudicial in the highest degree to the political, commercial and moral welfare of the country.

On the basis of this series of propositions I would recommend :-

(i.) That the principle of railway nationalisation be not adopted in the United Kingdom.

(ii.) 'That, in place thereof, the railway companies be permitted and encouraged to make, where necessary, such alliances or arrangements among themselves as would allow of desired 
426 Rallways and Nationalisation.

economies being effected, without any disadvantage-and even with actual material benefit-to the community.

(iii.) That Parliament, traders, and the public in general should show a more sympathetic attitude towards the railways, which have done so much to promote the national well-being; and should assist rather than retard, exploit, and nullify, a rational policy which would secure the best results that could possibly follow from railway nationalisation, while avoiding the risk of its many attendant evils and disadvantages. 


\section{APPENDIX.}

\section{THE ROYAL COMMISSION OF 1865.}

The question as to whether or not the State should acquire the railway system of the United Kingdom was fully considered by a Royal Commission on Railways appointed-under the presidency of the Duke of Devonshire-in 1865 . The Commission decided against recommending any such step, their references to the subject in the report they presented (now out of print) being as follows :-

\section{Government Purchase of Railways.}

Having thus described the origin and progress of the railway system, we proceed to enquire whether any fundamental change is required in it by the public interests.

It was clearly contemplated by Parliament that it might be desirable at a future time to reconsider the relations of railways to the State, inasmuch as it is stated in the Act of I 844 that it is not intended to prejudge by its provisions the policy of revision and purchase, but to leave the question open for the future consideration of the Legislature upon grounds of national policy.

As the period of 2 I years fixed by that Act for the purchase of railways authorised in 1844 has now elapsed, the proper opportunity for a full examination of the question has manifestly arrived. 


\section{Act of 1844 .}

We will in the first place examine the provisions of the Act of 1844 , and the manner in which they could be carried into effect.

The Act provides that after the end of 2 I years from the ist January next after the passing of any Act of the Session of 1844 or any subsequent Session of Parliament for the construction of any new line of passenger railway, such line of passenger railway, whether a trunk, branch or junction line, sanctioned in that or any subsequent Session, and whether such new line be constructed by a new company or by an existing company, shall be liable to be purchased for a sum equal to 25 years' purchase of the average annual divisible profits for three years before such purchase, provided these profits shall equal or exceed to per cent. on the capital; and if not, the railway companies shall be at liberty to claim any further sum for anticipated profits, to be fixed by arbitration.

The company owning such line is to keep and render to the Treasury accounts of the receipts and expenses for the three years, distinguishing such receipts and expenses, if a branch, or if worked in connection with other railways, from the receipts and expenses on such other railways.

It is especially enacted that the cption of purchase shall not extend to any railway the construction of which was authorised before the Session of 1844 . But any railway company subject to its provisions may require that if the Government purchase a branch of their line sanctioned subsequently to 1843 , they shall also purchase the whole of the company's lines.

It is declared by the Act that, in order to prevent the public resources from being employed under these powers to sustain an undue competition against any independent company or companies, the powers 
are not to be exercised by the Treasury until Parliament has by law authorised the guarantee or the levy of the purchase money and determined the manner in which the option is to be exercised.

\section{Railways exempted.}

There were $2,320 \frac{1}{2}$ miles of railway sanctioned before the Session of 1844 , which are, therefore, ex. cluded from the provisions of the Act. The follow. ing statement shows the companies to which these railways belong, with the length of each.

Rallways Authorised by Parliament to the END of The Session of 1843. AND Whicil are Now OPEN :-

Birkenhead :

Chester to Birkenhead

Bodmin and Wadehridge .

Bristol and Exeter.

Miles

Caledonian :

Glasgow, Garnkirk, and Coal bridge

Polloc and Govan:

Paisley and Greenock

Dundee and Newtyle: 101

Wishaw and Coltness : $13-57 \frac{1}{2}$

Dublin and Drogheda

Dublin and Kingstown

Dundee and Arbroath

Glasgow and South-Western:

Main line . $\quad 5 \mathrm{t}$

Kilmarnock and Troon:

Paisley and Renfrew : $3-64$

Grcat Eastern :

Iondon to Colchester . 51

Stratford to Newpot t : $3^{8}$

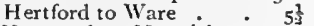

Varmouth to Norwich : 21 - II5

Great Western :

London to Bristol . . II8

Didcot to Oxford : 9 .

Swindon to Cheltenham : $4^{8-176}$

I.ancashire and Yorkshire:

Nanchester to Norman-

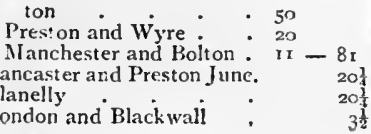

London and North Western : 16. London and Birmingham $112 \frac{1}{2}$

75 Liverpool \& Manchester 31 Manchester and Birming-

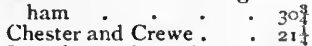
Leamington Branch : 83

Blisworth and Peterboro' Aylesbury

Kenyon and Leigh and Bolton and Leigh . $9 \frac{1}{2}$

West London - . . 3

North Union : . : 40

St. Helen's : . 10 $-4^{\text {ns }}$

London and South-Western :

Nine Elms to Southampton . $78 \frac{1}{4}$

Bishopstoke to Gosport : $15-9$

London, Brighton \& South Coast :

London to Croydon

Croyd $n$ to Brighton: $42^{2}-5^{3}$

Manchester, Sheffield and Lincolnshire :

Manchester to Sheffield - $40 \frac{1}{2}$

Maryport and Carlisle . $28 \frac{4}{8}$

Midland:

$\begin{array}{lll}\text { North Midland } & \cdot \quad 72 \frac{1}{4} \\ \text { Midland Counties: } & \text { : } & 58 \frac{1}{2}\end{array}$

Birming'xam and Derby Junction .

Sheffield and $\dot{R}$ otherham

Bristol and Gloucester .

Birmingham \& Gloucester

Leicester \& Swannington
Miles

47

9星

$$
5 \frac{7}{4}-9
$$

$8 \frac{3}{4}$

\section{$\frac{1}{2}$}

$48 \frac{1}{2}$
$7 \frac{1}{12}$
$30 \frac{1}{1}$
$55^{\frac{1}{2}}-289 \frac{1}{4}$
10 


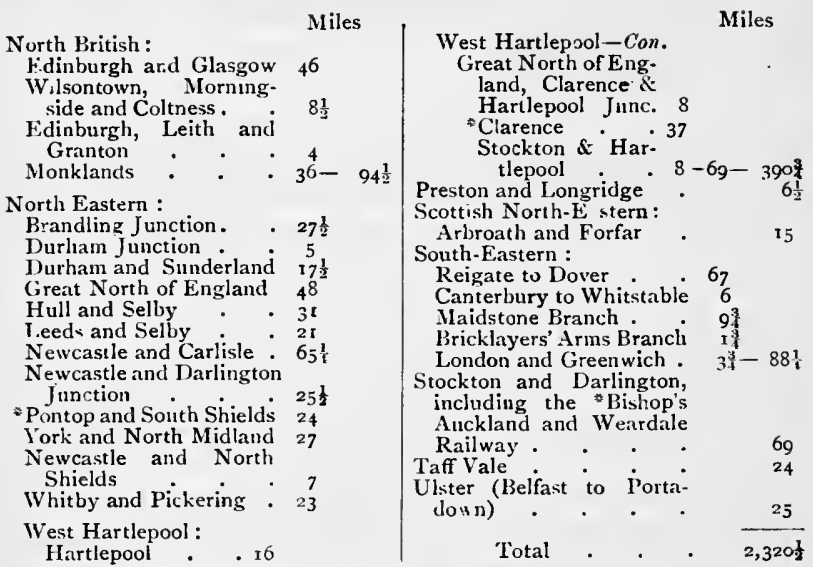

NoтE - The railways marked thus * being principally used for mineral traffic may perhaps not be considered passenger railways under the Act.

This list includes (with the exception of the Great Northern Railway) the main lines of communication throughout England.

It would, therefore, appear that if the State elected to purchase the railways, it would never, unless with the concurrence of the proprietors of the lines, become the possessor of the whole of the principal main lines of railway, such as the Great Eastern, London and North Western, Great Western, and London and South IVestern, but in these cases would become possessor only of numcrous lines which (like the Trent Valley) are integral parts of the several systems; nor would the State at the present time become the owner of more than those lines, or parts of lines, or branches which were sanctioned during the years 1844 and 1845 . In every succeeding year it would be entitled to take so much of the existing railways as was authoriced in the twenty-first preceding year. 
Accounts Required.

It would be very difficult, even if it were possible, to frame accounts to show with any approach to accuracy the receipts and working expenses upon these separate portions of railways so as to form a basis for purchase.

This condition of things is sufficient to account for the Treasury not having required the companies to render any such accounts of receipts and expenses as were contemplated by the Act of 1844 .

\section{Supposed Financial Advantages.}

The question, however, of Government purchase deserves full inquiry in a broad point of view, and the expiration of the period fixed in the Act of 1844 affords a good opportunity for inquiring, with the help of the experience which has now been acquired, whether a change of system is desirable.

The transfer of the railways to the State has been recommended by several witnesses, partly for the sake of its direct financial advantages, partly as affording the means of introducing an improved system of management.

The expectation of direct financial advantages is based upon the assumption that, as the Government can borrow money on more favourable terms than any other parties, this difference in the rate of interest would either be available as profit to the State or would afford an opportunity for the reduction of rates.

It is possible that a profit from this source might be obtained, if Government could buy the railways at 25 years' purchase of their average net profits; but at present unless the profits amounted to ro per cent. on the capital expended, an additional amount would have to be paid, to be fixed by arbitration, and 
it is probable that any arbitrator between the Government and private companies on such a question would make a very large allowance for future increase of profits.

There being also above 2,300 miles (including some of the most important lines in the country) not subject to the Act of 1844 , the purchase of these lines, which would be absolutely necessary to carry out the scheme, could only take place with the consent of the proprietors, and this could only be obtained by the offer of liberal terms.

It is probable, therefore, that in practice much of the assumed profit would disapear in the extra price, above the assumed 25 years' purchase, which would have to be paid.

In addition to the diminution of assumed profit arising from this cause, it must not be forgotten that as the Government would have to enter the

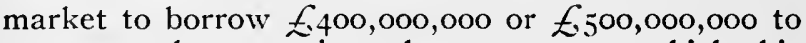
carry out the operation, the terms upon which this could be raised would in all probability be materially affected.

The depressing effect upon public securities would be equally felt whether the Government conducted the whole operation at once, or whether it came into the market year after year to repeat an operation of about $\mathcal{E}_{25}$, ooo, ooo a year ; and it is not easy to foresee what the price of Consols would be under the proposed addition of $£ 500,000,000$ to a national debt.

It is therefore probable that the Government would nave to exchange the income of the railway companies for an cquivalent income in Consols, to avoid being called upon to make cash payments for the purchase money, which would have to be paid out of money borrowed in Consols.

It cannot therefore be expected that under the provisions of the present law much profit could result to the State from the transaction as a financial operation, 


\section{Improved Management. Leasing.}

We have next to consider whether, if the State owned the railways, it would be able to improve the system of management. None of the witnesses have recommended direct management by Government officers; but, in the opinion of some, great advantages would be derived from the adoption of a plan of leasing the railways in groups.

In the absence of any sufficient data furnished from experience it is difficult to express an unqualified opinion on this proposal, but we are unable to perceive that the expectation referred to rests upon any solid foundation.

The capital required by lessees for working a group of lines would no doubt be comparatively small, but yet it is manifest that Government could not safely enter into engagements with any lessees who are not prepared to give ample security for the payment of the stipulated rent.

Practically, therefore, the lessees would be either joint stock companies or wealthy capitalists; if the former, there is no ground for assuming that the directors of these companies would possess qualifications not to be found in those who now manage the affairs of railway companies ; if the latter, they would not in most cases individually possess the knowledge or experience required for the direct management of the concern. In either case, therefore, it is probable that the actual conduct of the business would fall into the hands of the present staff, as the selvants of joint stock companies or private capitalists, but if other persons undertook the duty there is no guarantee that they would possess more capacity than the present officers, while it is clear that they would possess less experience.

Again, the transaction must necessarily be attended with risk to the lessee. They would be in 
this position: if the net earnings should exceed the rent even by a small amount, such small excess might afford a good dividend on the comparatively small capital invested by them; but, on the other hand, if the rent should exceed the net earnings by only a small amount they would be altogether deprived of any dividend. It is therefore naturally to be anticipated that any lessess, in calculating the rent they would be prepared to offer, would make large allowances for the speculative character of the undertaking, and consequently it is far from manifest that the State could rely on obtaining a rent adequate to reimburse it for the outlay in purchase. It further appears to us improbable that lessees would be found willing to fetter themselves by conditions imposing on them the reduction of fares and rates, or otherwise depriving them of the liberty of managing their affairs as they might think most conducive to their interests; and we are unable to perceive that their position would be more favourable than that of the existing boards for trying the effect of experiments, which, though they might ultimately be advantagcous, would, on the assumption we have made, necessarily be attended with immediate loss.

It has not been distinctly pointed out to us in what respects it is to be expected that the system of management by lessees would be superior to that of the existing boards; but it is obvious that there are but two possible sources of improvement, viz. : (I) the reduction of working expenses; and (2) the obtaining a greater amount of work from the engines and carriages, and so increasing the receipts in proportion to the expenses.

We shall have occasion in a further part of this report to refer at length to these questions; at present it may be sufficient to remark that these are questions the bearing of which is thoroughly understood and the importance appreciated by the general managers and other railway officers, persons for the 
most part well qualified by their sagacity and ability for their position.

The general result of our enquiries is, that in the great heads of expenditure an increase rather than a decrease is to be anticipated, and that the economy arising from carrying full train loads could be obtained only at the sacrifice of convenience and accommodation.

Further Objections to Government Purchase.

The financial view of leasing railways to companies for limited periods involves this further consideration. Either the improvements required to the lines and stations to provide for additional accommodation must be directly paid for by the State, or the State would have to allow for them at the end of a lease. In either case the question of the necessity and the mode of the execution and cost of the works would require a detailed consideration on the part of the Statc.

The Crown as the owner of the railway property of the country would be obliged to employ properlyqualified engineers and others to investigate the details above mentioned, and to watch over the national property, in order to take care that it was kept in proper working order by its lessees, and that all the conditions of the leases were duly complied with. Considering the great responsibility and delicacy of the duties they would have to perform, this staff of officers would have to be highly paid; and, having regard to the manner in which establishments have grown up in this country, bringing in their train compensations and superannuations, the expense on this account would probably ultimately become a not inconsiderable percentage on the receipts from the lessees.

The practical result of any scheme for the national purchase and leasing of railways would merely be to 
substitute the lesser sense of responsibility of a lessee for a limited period administering the property of others, for the heavier and more durable responsibilities of owners managing their own property. But if the Government as lessors interfered to any great extent with their lessees, there would then be a divided and a still less efficient administration, of which any profit would go to the lessees, whilst any loss resulting from it would in the end be made to fall on the public revenue.

There is yet another difficulty contingent on the proposal which should be adverted to in considering the question of the purchase. of railways by the Crown and their lease to companies or individuals. The original terms of the lease, and the more or less stringent enforcement of its conditions, might be tempered by political considerations, seeing how large an influence the railway companies necessarily must exercise in the localities which they severally accommodate. Therefore the exercise of a discretionary power over them would be open to serious objections, and would inevitably lead to abuses.

These consequences could only be guarded against by defining the power and duty of the Crown in respect of the railway property by the most precise enactments, which would in effect regulate the use of the railways by positive laws of general application. But it is impossible to over-estimate the difficulty of framing such general laws as would be applicable to the many particular 'cases which arise from the great variety and diversity of productive and commercial undertakings in this country.

And, as there is no intention of cheapening the means of conveyance by railway at the expense of the national exchequer, all general laws should be such as would not entail any loss in the administration of the railways.

Parliament has reserved to itself the right to pass any general law to regulate the railways owned by 
the several companies, therefore it would be just as easy to legislate on this basis for the existing system; and hence any alteration in the law, if desirable, could be obtained by the machinery of the present companies without transferring the administration of the railways to new companies.

Hitherto our remarks have been confined to the railways merely, but the railway enterprise of the country has not been so restricted. It has, on the contrary, extended to a great number of collateral undertakings, not only to extensive factories for the construction or repair of its works and rolling stocn, to large stations, machinery, warehouses and other matters for the receipt and delivery of goods, and to arrangements for the supply of coal, but also to the subsidiary undertakings of canals, docks, harbours and steam versels, to facilitate and economise the transport of passengers, animals and merchandise. These have been by special Acts declared part of the undertakings of the several companies, and have been carried on out of their capital. The earnings and expenditure on account of them have also been blended with the revenue and working expenses of the companies.

We think the Crown, if it purchased the railways, would be compelled to become the purchaser of all these subsidiary undertakings; but it would then become necessary, as soon as this new policy had been adopted, to consider the position of the rest of the canals and docks which are not so connected with railways, and which under such an arrangement rould be to some extent obliged to carry on a competition with the State and its resources.

In the event of the Crown becoming the owner of the cxisting railways, it would either be necessary to adopt some entirely new system in regard to the further construction of railways, or their construction would devolve entirely upon the State.

Either proposals for new lines would be dis- 
couraged by the Government as tending to diminish the revenue; or, if this consideration were disregarded, schemes might be devised for new lines, so as to leave those existing a charge upon the State. At present these difficulties are of no public concern, being the ordinary contingencies incident to private enterprise. In any case, however, an end would be put to the present spirit of enterprise on the part of existing railway companies or others; but the liberty which is at present enjoyed of promoting new lines of railway is not only the best safeguard against abuse, but the surest means of securing for the public the greatest benefit from the present system.

\section{French Opinion.}

We would, in conclusion, call attention to an extract from the report of the French Commission which reported in 1863 upon the construction, working and management of French railways; the Commissioners, whilst vindicating their own system of regulated protection, observe as follows :-

" One understands the complete liberty of action left to the English companies by their Special Acts in that country of free competition, where the antagonism between private interests, constantly in presence of each other, has long been recognised as an essential condition for duly protecting the public interests. By virtue of this system, which has been applied without reserve to railway concessions, very active competition exists between the English railway companies, so much so that as soon as the apathy or want of intelligence of one company allows the service of its line to deteriorate, a new enterprise springs up, and by offering greater facilities to the public appeals to the trade of the country, and forces the first company to bring its working up to the level of public requirements. In France, the absence, almost complete up to the present time, of 
all competition amongst railways, discards that valu= able equilibrium which is the safeguard of British industry."

\section{General Conclusions.}

On the various grounds we have mentioned we cannot concur in the expediency of the purchase of the railways by the State, and we are of opinion that it is inexpedient at present to subvert the policy which has hitherto been adopted of leaving the construction and managenient of railways to the free enterprise of the people, under such conditions as Parliament may think fit to impose for the general welfare of the public.

\section{IRISH RAILWAYS.}

Proposals for Government Purchase.

It has, however, been suggested that Ireland might be treated in an exceptional manner. It has been urged by the witnesses from that country, and also by other gentlemen of experience connected with railways, that there would be no financial difficulty in purchasing the Irish railways, and that the purchase might be effected on terms which would allow of such a saving in the interest on debentures and dividends on preference capital as would afford a margin fairly applicable to a reduction of rates. They also urge as an additional recommendation of the measure that it offers the only practicable means of escaping from the evils arising from the excessive number of small independent companies.

The capital sanctioned for the Irish railways is about $£ .36,000,000$, but of this only $£ .26,390$,ooo was actually raised by shares and debentures at the date of the last return in I 865 . Hence their purchase by the State would not be exposed to financial obstacles as in England, but in all other respects the proposal is open to all the objections to which we have adverted in the foregoing ubservations. In one par. 
ticular it may be deemed more objectionable than in the case of the English railways, inasmuch as it is of more importance not to discourage private enterprise and self-reliance in that country.

We shall not here make any further reference to the question of amalgamation, but shall return to the subject in a subsequent part of the Report.

Besides the proposal for the direct transference of the Irish railways to the State, various suggestions have been laid before us involving the principle of affording the aid of the State, with a view to the reduction of rates. By some witnesses it has been recommended that advances should be made to the companies sufficient to enable them to pay off their debenture debt and their preference capital on condition of an equivalent reduction of rates; by others it has been proposed that a certain proportion of any loss which might result from such reduction should be borne by the State. All these proposals appear to us to be contrary to sound principle.

It would be unjust to subsidise railways in order to induce a reduction of rates without doing the same for canals, inland navigations, and other means of locomotion of a proprietary character. The subsidy would have to be extended to future railways for those parts of Ireland not yet provided with railway facilities.

When capitalists undertake to construct a railway for the conveyance of persons and things at a lower rate than they can otherwise be conveyed, they unquestionably confer a great advantage on the public; but this furnishes no reason for the Government undertaking to reduce still further the cost of conveyance by giving the aid of its credit, or by making good the loss out of the public treasury.

The proposal to give a subsidy is therefore to pay out of the public treasury for a further reduction of the cost of conveyance, when a great reduction has already been made by means of a special contrivance, 
but to pay nothing when no reduction has been made because the ordinary road is obliged to be used.

No facts have been disclosed to us in evidence which would justify us in disregarding these considerations, or in recommending for adoption any of the proposals above adverted to.

\section{Inadequate Dividends.}

Ireland has certainly no reason to be dissatisfied with the extent of railways constructed in it under the present system. In proportion to the resources of the country it is fully equal to that of the lines in the rest of the United Kingdom. It is complained that their profits have been for the most part insufficient; but the inadequacy of the returns appears to be due to causes which are not peculiar in Ireland, but exist in England where the circumstances are similar.

The main sources of the prosperity of English railways, viz., the large transport of passengers, arising from commercial activity and a wealthy population, and the carriage of goods arising from great manufacturing towns and mineral production in the centre of England, do not exist in Ireland; but where these elements are wanting, as in the agricultural counties of Norfolk, Suffolk, and Essex, and in the centre of Wales, the railways are as unprofitable as any in Ireland.

\section{Alleged High Rates.}

On the part of the public it is complained that the charges are so high that the resources of the country are in consequence not developed. An opinion has also been very generally expressed, with more or less confidence, that the increase of traflic which would follow a large reduction of charges would be so great as ultimately to entail no loss. There is no doubt that in certain circumstances a well-considered reduction is advantageous, and we understand that 
in some cases where the policy of lower fares than usual has been adopted by railway companies the results have been satisfactory, but we have no facts before us to justify an opinion that a general reduction on a large scale would not be attended with loss.

The geographical position of Ireland, and the condition of its industry, are by no means favourable for a great increase of railway traffic. The country enjoys in a remarkable degree the benefit of natural harbours, creeks and rivers, so that no part of the country is more than fifty miles distant from a convenient port, whilst the greater part is much nearer. The mineral productions are raised, and the manufacturing industry is carried on near the sea coast, where the principal towns are situate, and enjoy the advantage of importing their raw material from atroad by sea.

The industry of Ireland is mainly employed upon agriculture, and the amount of traffic from such industry is necessarily limited in quantity as compared with that of manufacturing districts.

The imports into the interior are in like manner restricted to the comparatively small bulk or weight of articles other than food produced and consumed by a rural population, whilst the absence of commercial activity, or of a wealthy resident population in the central parts of Ireland, produces to the lowest degree both the necessity and the disposition to ti avel.

It has been complained that the cattle trade is prejudiced, and there is no doubt that a large quantity of lean stock are driven from one part of the country to another along the roads, and are not conveyed by railway. As there are many districts at a considerable distance from the nearest railway, much of this description of stock would still continue to travel by the roads, however large a reduction might be made in railway rates. It is stated, also, by the witnesses who have given evidence on this question, 
that nothing short of a very great reduction in rates would induce graziers to send their lean stock by railway; and as this description of traffic, even at present rates, does not appear to be very remunerative, it is evidently probable that a reduction of fifty per cent., as is asked for, might be attended with serious loss.

The coal traffic of Ireland is very limited in quantity. The bogs have hitherto supplied much of the interior with fuel, but peat seems to be gradually becoming dearer with the rise in the wages of labour, and coal will therefore naturally have a tendency to supersede it. It is probable that if its price could be materially reduced, an important stimulus would be given to its consumption. The charge, however, for transporting coal at Dublin from ships to the railway stations is stated to be $3 \mathrm{~s}$. $6 \mathrm{~d}$. per ton, a sum equal to fifty per cent. of the railway rate to the centre of Ireland, and unless the cost of this transport can be reduced, no lowering of railway rates would have a fair trial or could have much effect. It is not immaterial to remark, in reference to this question, that coal is not dearer in the interior of Ireland than in the south of England.

It has been stated that the development of mining industry is not encouraged by the railway companies; but it does not appear that any offers of valuable inineral traffic have been made to them and declined. It must be borne in mind that mineral traffic at low rates is profitable only when conveyed in full train loads and for considerable distances.

As the average distance for which goods could be conveyed in Ireland cannot be estimated at more than thirty miles, the effect of a reduction of rates in stimulating industry and enterprise would not be such as to alterr the conditions under which they now exist in Ireland. After making a reasonable allowance for terminal charges a reduction to one-half the present rate, which may be taken at the average of 
I $\frac{1}{2} \mathrm{~d}$. per ton per mile, would only be is. IO $\frac{1}{2} \mathrm{~d}$. a ton for thirty miles, or less than $6 \mathrm{~d}$. on a quarter of grain, and about $1 \mathrm{~d}$. on a cwt. of flax.

Results of Railway Enterprise in Ireland.

A comparison of the results of railway enterprise in Ireland with that in Scotland forcibly illustrates these considerations. The population of Ireland at the last census was $5,798,967$, that of Scotland $3,062,294$. At the end of 1865 there were 2,200 miles of railway open in Scotland, the cost of which had averaged $\mathcal{E}_{22}, 82 \mathrm{I}$ per mile. In Ireland there were 1,838 miles of railway open, the cost of which had averaged i 13,965 per mile. The gross receipts from traffic for the year in Scotland amounted to $\mathcal{E}_{\mathrm{I}}, 8 \mathrm{I}$ 2 per mile of railway, and in Ireland to $£ 945$ per mile of railway; and whilst the net receipt in Scotland yielded 4.4 per cent. on the whole money invested, in Ireland the. net receipt yielded only 3.5 per cent. The rates authorised to be levied by the railway companies are as high in Scotland as in Ireland. It is owing to the different circumstances of the country and the condition of its industry that railways are more profitable in Scotland than in Ireland.

General Conclusions and Recommendations.

On these several grounds, having come to the determination that it is inexpedient that the railways should be purchased by the State, we consider that there is not sufficient reason for excepting Ireland from this general conclusion; but as it has been the established policy to assist railways and other public works in Ireland, we recommend that when Parliament thinks fit to make advances to Irish Railway Companies the money should be lent for a fixed period of considerable length, so as to enable the company to develop its resources before it is called 


\section{Royal Commission of 1865 .}

on for repayment. We are, however, of opinion that advances should not be made to the Irish railway companies as a condition of reducing their rates and fares, but that as the railway companies have the best opportunities of judging whether rates can be reduced so as to be recuperative within a reasonable time, they should be left to carry out such experiments at their own risk. 



\section{INDEX.}

Acr of $1844,296-301,310$ Adam, Sir F. Forbes, 386 Advertising, Railway, 323-4 Agricultural Co-operation, 352, 362

Agricultural Produce, 360-I

Allerton, Lord, 402-3

Amalganated Society of Railway Servants, $144,146,156$, 173, 392

Amalgamations, Railway, 338 , $3+7,370-1$

Antwerp, Transit Traffic, 254 $-5,258$

Argentina, Railways in, 251

Aspinall, Mr. J. A. F., 342

Askwith, Mr. G. R., 386

Asquith, Mr., 295, 377-8, 379

Austria, Financial Results, 100 ; Tariffs, $289-290$

Automobilism, Nationalisation and, $315-6$

Balfour, Mr., 335

Barry Railway Company, 3I3

Beasley, Mr. A., 386

Belgium, Reasons for State Ownership, 25-6; Financial Results, 98-100; Political Influences, 135-6; Railway Accidents, 179-180 ; Belgian Traders' Views, 249; Transit Traffic through Ant werp, 254 -5 ; Collieries in Belgium, 759; Density of Population, 359 ; Light Railways, 424
Bell, M.P., Mr. Richard, 146, I 53

Bent, Mr., 66

Bingham, Mr. D. G., 256

Bismarck, I'rince, 21, 22, 23, 24

Blount, Sir Edward, 4I

Board of Trade, Powers of Control, 177 ; Requirements of, $344-5$; Complaints to, 385 ; Conference, 386

Bonsor, Mr. H. Cosmo, 377

Briggs, Mr. W. A., 248

Brassey, Lord, 60

Brassey, Mr. Thomas, 4 I

Brazil, Reasons for State Purchase, 33 ; Results of Operation, IO4; Railways and Politics, 135

Brunner, Sir John, 175

Burlet, M. C. de, 424

Burton, Mr. W., 386

Butterworth, Mr. A. Kaye, $3^{86}$

Caledonian Railway, 389

Canada, State, Provincial and Municipal Aid to Companies, 5I-3; Intercolunial railway, $94-6$

Canadian Pacific Railway, 52

Canals, Dortmund-Ems Canal, 263-4; State and Canals in Germany, 265-6; Canals and Railways in England, 3 I4 Canvassers, 328

Cape Colony, Early Days of Cape Railways, $3^{8}$; Railway 
Finance, $84-90$; Fostering Local Industries at Cost of Railways, 87 : Overmanning, 87 ; Excessive Red-Tape, 88; Po'itical Influences, 129I3I ; Railway Men and P'olitics, 154

Capital, Railway, 302, 305-6

Cattle Trains in New South Wales, 250

Cawdor, The Earl of, 203

Central South African Railways, Financial Basis of Operation, 93-4; Political Influences, 132-3; Jolitics and Colon al Policy, I33-4 ; Railway'Servants and Politics, 153-5 ; Rigidity of Rates on State Railways, 190

Chile, Results of Operation, I04-5

Churchill, Mr. Winston, Views on Railway Men as State Servants, 153-5

Clark, Mr. Victor S., 84

Clemenceau, M.,?139

Coal .Consumption, I $74,389-$ 390

Coasting Steamers, 312

Coghlan, Mr. T. A., 62, 73

Collection and Delivery, 278 280

Colson, M., 1424

Company Operation of Stateowned Lines, Holland, 6; Mexico, 7 ; India, 7 ; Brazil, 33 ; Belgiun, 424

Company Ownership of Railways, Statistics, I2-19; State Control, 176-7; the Question of "Private Profit," 180-1 ; English and Foreign Lines Compared, $1182-3$; Initiative and Enterprise, $184-5,326$ -7; Preferable for Ireland, 355-6

Competition, British Railways, 57, 371-2; Between Kiver and Rail, in Germany, 257$26 \mathrm{I}$; Water and Rail, in Holland, 259 ; Competitive Routes on the Continent, 261 -2 ; Inter-State Competition, 268 -9; International, 269270

Competitive Routes, 26 I-2, 268

Construction, Cost of, in the United Kingdom, 56, 183 , 205-214; on the Continent, 275-7; World's Railways, 217-8

Cooke, MIr. A., 368

Credit to Traders, 242

DAVis, Mr. A. Enil, 318, 374

Delivery of Goods, on the Contiment, 183, 282-3; in the United Kingdom, 240, 344, 38o-2

1)emurrage, Charges for, in Germany, 280- I

Denmark, Local Authorities Aid Railway Construction, 9 ; Reasous for State Ownership, 27-8; State Aid to Companies, 48 ; Financial Results on State Lines, IOI-2 ; Railway Consignments, $360-1$; Government Subsidies on Transport, 361 ; Incidence of Production, $362-3$; Sunday Work, 363 ; Winter Dairying, 363; Danish Peasant at Home, 364-5; Denmark and Ireland Compared, 366-9

Directors, Railway, 318-320, 340-I

Dividends, Railway, 304-6

Docks, Railways and, 312-3

Dortmund-Ems Canal, 263-4

Eiwards, M.P., Mr. Clement, 222, 227

Edwards, Mr. C. L., 392-3 
Edwards, Mr. W. B., I 29

Electric Traction, 308

Ell, Mr. Henry G., 84

Ellis, Mr. Ratcliffe, 386

Engineering Works, Railway, 313

FAY, Mr. S., 386

Field, M.P., Mr. IVilliam, $220-4,227$

Finances of State Railways, Germany, 60, 6I ; Russia, 60 ; Belgium, 6I : Italy, 6I ; Switzerland, 61 : Australia, 6I, 65; New South Wales, 62-6: Victoria, $66-72$; Queensland, 73-6; South Australia, 76-7; Tasmania, 77 ; Western Australia, $78-$ 8I; New Zealand, 82-4; Cape Colony, 84-9o ; Natal, $90-92$; Central South African Railways, $92-4$; Canada, 94-6: India, 96-8; Belgium, 98-I00; Austria, IOO; Russia, IOI ; Denmark, IOI-2 ; Switzerland, IO2-3; Italy, I03; Servia, IO3; Honduras, IO4 ; Brazil, IO4; Chile, I04-5; Japan, $106-$ 7 ; Prussia, IoS-I 19

Forbes, Mr. James Staats, 256

Forwarding Agents, 274, 289

France, Local Authorities Aid Local Lines, 9 ; Reasons for State Ownership, 28 ; Purchase of Western Company's Lines, 29 ; State Aid to Companies, $4 \mathrm{I}-\delta$; Political Influences, I38-9; Military Operation of State Lines, I62 ; Routine, 19I-4 ; Transit Rates, 269; Published Tariffs, 289 ; Economic Position, 359 ; Great Companies in United Kingdom and France Compared, 418-9
Franks, Mr. IV. Temple, I74

Free Passes for Legislators, 132

George, Mr. William J., 78

Germany, Reasons for State Ownership, 20-5; Prussia, 21-3; Wiirtemberg, 23 ; Bavaria, 23; Baden, 23 ; Saxony, 24 : Oldenburg, 24 ; Mecklenburg Friedrich-Franz Railway, 25; Imperial System in Alsace-Lorraine, 25 ; Political Influences, I36-8; German 'Traders' Grievances, 245-7; German Railways from an English Standpoint, 247-8; Rail v. Water, 257 -26I ; Competitive Rontes, 26I-2 ; Export Rates, 262 -3; Length of Haul, 27 I -2: Rate Comparisons, 277 -286 ; Goods Train Services, $282-3$; Railway Tariffs, 287 -9 ; Railway Fares, 290-3 ; Economic Position, $35^{8-9}$

Gladstone, Mr. IJerbert, I74, 389

Glasier, Mr. Bruce, I

Gorst, Sir John, 6I, I45, I 55, I 56

Granet, Mr. IV. Guy, $3^{86}$

Grierson, Mr. J., 22 I

Great Central Railway Company, 310, 312, 388, 390, 394, 398-402

Great Eastern Railway Company, 3IO, 388, 390, 394, 398 $-401$

Great Northern Railway Company, 388, 390, 394, 398-403 Great Northern of Ireland, $35^{2}$ $-3$

Great Western Railway Company, 203, 3I2, 325, 37 I, $388,390,394,420$

Greece, State Aid to Companies, $49-50$ 
Guarantee of Interest, $42-8$, 334,337

HAMILTON, Lord Cland, 400-I Hardy, M.P., Mr. G. A., 2, $182,205,226,228$

Haul, Average Length of, in Germany, 272; in Great Britain, 272

Heaton, M.P., Mr. Henniker, I99, 200

Henderson, Sir Alexander, 4OI $-2$

IJertslet, Sir Cecil, 254

llill, Rowland, 199

Holland, Company Operation of State Lines, 6; Reasons for State Ownership, 26-7 ; Political Considerations, I 39I43 ; Strike of Railway Men, I62- 5 ; Dutch-Rhenish Railway, $256-7$; Transit Traffic, 257-8; Water $v$. Rail, 259

Honduras, Railways in, 104

Hotels, Railway, 31 3, 353

Hours of Labour, Shorter, 391

Hubert, M., 99, 100

Huil and Barnsley Railway, 388 Hungary, Railway Strike in, $157-162$

INDIA, Company Operation of State-owned Lines, 7-8; Reasons for State Action, 36-7: State Aid to Companies, 50 ; Financial Results of operation, $96-8$

Inglis, Mr. J. C., 386

Intercolonial Railway (Canada), 52

Ireland, Vice-Regal Commission, 82, 331, 336-354 ; Situation in Ireland, $332-3$; State Loans to Railway's, 333 ; Baronial Guarantees, 334 ; State Grants, 335 ; Railway
Position To-day, $336-8$; Question of Extensions, 338$34^{\circ}$; Railway Directors, 34I ; Irish Railway Clearing House, $342-3$; Savings, $343-5$; Increases in Expenditure, 345-7; Amalgamations, 347 : 'Traders' Grievances, $348-$ $35^{\circ}$; What the Companies have Done, 350-3 ; Proposed Elective Authority, 353-6 ; Ireland Compared with Germany and Belgium, 359; Denmark, 366-9

Irvine, Mr., 166

Italy, Political Reasons for Railway Construction, 29; Kesults of Operation, IO3; Railway Advertising, 324

JaCksox, Mr. WT. F., 386

Jagger, Mr. I. W., $3^{8}$

Japan, Reasons for State Purchase, 31 ; Cost of Purchase, I06 ; Results of Operation, I06-7; Extensions and Betterment, 307-8

Johnson, Mr. O. D., 386

Joicy, Lord, I49

Kearley, M.P., Mr. Hudson, $3^{86}$

Kæenig, Dr. F. I', II 5

LABOUR and Railways, Excessive Number of Employés, Cape Colony, 87 ; Australia, 123; Railway Men's Wages in Belgium, 136 ; Labour and Politics in Germany, 136-7 ; in France, I38-9; in Hölland, 140, I43 ; Labour and Nationalisation, $144-5$; Decreased Staffs, I 45-8; Num. ber of Railway Workers, 148 ; 
Labour Vote and Interest, I49; Railway Men as State Servants, 152-5 ; Railway Troubles of 1907 , 156 ; the Railway Strikes in Hungary, 157; Holland, 162; and Victoria, 165; State Railways and Labour Unions, $172-3$

Labour Party, I, 8, I44, 324

Lancashire and Yorkshire Railway Company, 3 Io, 379, 388, $390,394,404,406$

Land Grants to Railway Companies, India, 50; Canada, 52-3; United States, 54-5

Law, Mr. H. C., 279

Leopold I., 25

Le Rossignol, Professor, 82-3, I 28

Levant Tariff, 266-7

Lewis, Sir W. T., 387

Light Railways, in Ireland, $334-7,339$; in Belgium, 424 Lloyd-George, Mr., 155, I56, $205,247,33$ I, 386

Loading and Unloading, 280-I Local Authorities, Action of, $8-9,375,379,403,415$

London, Brighton and South Coast Railway, $46,388,390$, 394

London and North - Western Kailway, 42, 313, 325, 370, $379,388,394,406-4$ I I

London and South - Western Railway Company, 312,388 , 390, 394

London, Tilbury and Southend Company, 390

Luxemburg, State Aid to Companies, $4^{8--9}$

Mexico, Company Operation of State-owned Lines, 7 ; Reasons for State Purchase, $3 \mathrm{I}-33$
Meyer, Mr. Hugo R., 235-7

Midland Railway Com pany, 31 3 , $325,388,389,394$

Mills, The Rev. H. V., I47

Miners' Eight Ilours Bill, I74, 389

Mitchell, Mr. N. H., 387

Mond, M.P., Mr. A., 387

Money, M.P., Mr. Chiozza, 6r, I08, I IO, 1 I I, 226

Moon, K.C., Mr. Ernest, 387

Mulvany, Mr. T. R., I I4

IIulsany, Mr. Willian T., 256

Natal, Railway Pioneering in South Africa, 37; Reasons for Government Action, 38 ; Character of Lines, 90 ; Financial Results, 91 ; Railway Rates, 9I ; Political Lines, I3I ; Free Passes for Legisla tors, 132: Railway Servants and Politics, 154

New South Wales, Reasons for Government Action, 35 ; Financial results, 62-6; Railway Commissioners, 124 ; Cattle Trains, 250-I ; Railway Wagon Shortage, 25I-2 New Zealand, Railway Finance, 82-3; Political Influences, $128-9$

Newfonndland, Railways in, 53 $-4$

North-Eastern Railway Company, 388, 394, 419- +20

Norway, Communes Aid Railway Construction, 9

O'DEA, Mr., 34I

Oppenbeimer, Mr., II5

Orange Free State. See Central South African Railways

Owner's Risk, in England, 244 in Germany, 246, 284-6

Owens, Sir C. J., $3^{87}$ 
PAGET, Sir Ernest, 408, 4I I

I'arkes, Sir Henry, 124

Parliament and the Railways,

Control over Rates, etc., I77-8; Attitude towards Railway Companies, 205-6, $373,377-9,403,412,414-$ 5,426

Parliamentary Procedure, Cost of, in England, 56, 212-3; in Prussia, 275

Parr, Mr. C. F., 200

Pearse, Mr. A. MI., 250, 25I

Perks, Sir Robert, 182

Peschand, X. Marcel, 135, I36

l'ate, Mr., I40, I4I

Plews, Lieut:-Col., 352

Politics and Railways, In Cape Colony, 86-7 ; Chile, 105; Australia, I23; Railway Commissioners Appointed, I $23-$ 4 ; Pressure of Labour Party in New South Wales, 124; Abuses in Victoria, 125-7; Bids for Votes in Queensland, I28; Votes and Railways in New Zealand, 128; Parliament and Railways in Cape Colony, I29-I3I ; Free Passes for Soutl African Legislators, I32; Views of Central South African Railways Commission, $132-3$; Railways and Colonial Polilics, I34; Position in Germany, I $36-8$; France, 138 9 ; Holland, I39-143 ; Labour Vote and Interest, 149; Example of Post Office Servants, I 50-2 ; Railway Men as State Servants, I525 ; Political Strike in Victoria, 165-I72; Politics and IVages, 325

P..st Office, I'olitical Pressure of Postal Servants, I5O-2 ; Organisation and Operation of Post Office, $198-202$
Power, Mr. John F., 366

Protection, Railways and, 2, II, 22, 23I, 235, 270-1

Prussia, Reasons for State Ownership, 20-23; Financial Results, I08-i I I ; Question of Betterment, I1 2-115 ; Wagon Shortage, 115-117; Further Expenditure on State Lines, I I $\mathrm{S}-9$; Government Routine, 194-7 ; Organisation of Prussian State Railway System, I95; Rates for Milk for Berlin, 235-7; Coal Wharfage in Berlin, 242 ; Credit to Traders, 242 ; Rail v. Water, 257-26I ; Competitive Routes, 26I-2 ; Export IRates, 262-3 ; Dortmund-Ems Canal, 263-4 ; State and Trader, 264 ; State and Canals, 265; Levant Tariff, 266-7 ; Inter-State Competition, 269; Railway Rates and Protection, 270-I ; Railway Loading, 272-4; Coustruction and Working Expenses, 275-7 ; Rates Exclusive of Collection and Delivery, 279; Loading and Unloading, 28o; Warehousing, 28I ; Conditions under which State System Purchased, 309 ; System of Control, 320-I

Purchase Terms, Socialist View, 294; Act of 1844, 296301 ; Outlook for State, 307 ; Extensions and Betterment, 307-8 ; Subsidiary Undertakings, 309-3I 4

Queexslaxd, Reasons for Government Action, 35 ; Financial Results, 73-6; Railway Commissioners Appointed, 124 
RaIlway Accidents, 178-180 Railway and Canal Commission, 177

Railway Clearing House, in London, 146, 321-2; in Dublin, 342-3

Railway Commissioners, Appointment of, in Australia, I23

Railway Nationalisation, Parties Favouring Demand, 2-4; Differences in Principles, 5-6; Company Operation of StateOwned Lines, 6-8; Action of Local Authorities, 8-9; State-Owned and CompanyOwned Lines Compared, 12 19 ; Reasons for State Ownership, 20-39; the Question of Firancial Gain, I19-120 ; Effect on Labour, I44-8; Labour Vote and Interest, 149; Example of Post Office Servants, 150-2 ; Effect on Political Position of Railway Men, 152-5 ; No Guarantee against Railway Strikes, I 55 -175; State Management not Superior to Company Management, 176-I90 ; Government Routine in France and Prussia, 190-7 ; Cost of Railway Promotion, 215: Purchase Terms and Conditions, 294-317; Question of Savings, 318-330; Nationalisation as Applied to Ireland, $33 \mathrm{I}-356$; National Prosperity and Nationalised Railways, 357-8 ; Railway Agreements Preferable to Nationalisation, 4I3, 42I-426

Railway Nationalisation Society, 3 , 180, 222, 227, 228

Railway Kates, Controlled by State in U.K., $57-8,177-8$, 4I7; Unremunerative Rates on Government Lines, Victoria, 68-70; Western Aus- tralia, 78-79; Cape Colony 87 ; South Africa, 9I ; Intricacies of Rate-making, 186190; Rigidity of Rates on State Railways, 190 ; Alterations of Rates in France, 190-4; in Prussia, 194-6; in the United Kingdom, 197 ; Alleged Excessive Rates, 218-226; Preferential Rates, 228-231; Equal Mileage. 232-4; American Railway Rates, 234-5 ; Milk Rates in Germany, 235-7 ; in England, 237-9; Prospects of Lower Rates through Nationalisation, 239; German Export Rates, 262-3 ; Levant Tariff, 266-7 ; Protective Rates, 270-1 ; Transit Rates in France, 269; Services Included, 277-284 ; Compari. sons Impracticable, 286 ; Continental Railway Tariffs, $287-290$

Railway Regiments, Hungary, 160 ; France, 162; Holland, 165

Railway Stations, Assistance in Construction of, $45-6$

Railway Workers, 148 . See also Labour and Railways.

Railways, British, Views of Ministers, 2, 295, 377-8 ; British and Foreign Kailways Compared, 39; Attitude of State Tuwards, 56--7, 205$6,414-5$; State Control of Rates and Charges, 57 ; Number of Railway Workers, 148 ; Facilities Offered, $182-$ 3 ; Relations of Traders with liailways, 197, 384-5, 417 ; Companies Plundered by Landowners, 207-212 ; Parliamentary Costs, $212-3$; Cost per Mile of Certain Lines, 214 ; Cost of Con- 
struction Compared with Other Countries, 217-8; Railway Rates, 218-233; Warehonsing and Wharfage, 24I-28I ; Credit to Traders, 242 ; Collection and Delivery, 278-9 ; Policy of Amalgamation, 370-I ; Policy of Competition, 37I-2 ; Combinations in self-defence, $372-4$; South-Eastern and Chatham and Dover Combination, 3746 ; Mr. Asquith's Views, $377-$ 8; Trade and Traffic, 379${ }_{3} \mathrm{~S}_{4}$; Board of Trade Committee, $385-7$; Wages and Materials, $387-8$; Train Mileage, $388-9$; Coal Bills, 3 S9-9o; Wages and Work, 390-2 ; Taxation, 392-3 ; Need for Action, 394-6; Solution of Problem, 396-8 ; Railway Companies' Arrangements, 398-4I2; Possible Difficulties, 4I 2-4 ; Parliament, Public, and the Railways, 4I4-420

Reid, Sir Robert Gillespie, 53

Renshaw, Sir Charles, 389

Rhine Traffic, 257-260, 269

Robertson, Mr. W. A., IS6

Rothery, Mr. F. M., 250

Rotterdam, Transit Traffic, $25 \mathrm{~S}$

Royal Commission on Railways

(I 865 ) , 177, 298, 339, $34^{\circ}$

Russell, Mr. Charles E., $3 \mathbf{I}$

Russia, Financial Results, IO I

SAlluelson, Sir B., 220-224 Savings, $3 \mathrm{I} 8-330$

Servia, Financial Results, $\mathbf{I O}_{\mathbf{3}}$ Sexton, M.P., Mr., 339, 354, 366,368

Siemens, Mr. A., 387

Smith, Mir. H. Llewellyn, 386

Snowden, M.P., Mr. Philip, 294,295
Jocialists and Nationalisation, I, 294, 295

South African Produce Rates, 9I South Australia, Financial Results, $76-7$; Railway Commissioners, $123-4$

Shareholders, Railway, 302-4, 385

South Eastern and Chatham and Dover Companies, 374-7, 394 Spain, State Aid to Companies, 49

Spender, Mr. J. A., $3^{87}$

Stalbridge, Lord, 407, 410-I

State Aid to Private Companies, 40 ; France, 4I-8; Denmark, 48 ; Luxemburg, 48 ; Spain, 49; Greece, 49-50; India, 50 ; Canada, 5I-3; Newfoundland, 53 ; United States of America, 54; Ireland, 333-7 ; Denmark, 36 I

State Ownership, Reasons for, Germany, 20-5 Belgium, 25-6; Holland, 26-7; Denmark, 27- 8 ; France, 28-9; Italy, 29; Switzerland, 30 ; Japan, 31 ; Mexico, 31 ; Brazil, 33 ; British Colonies, 34 ; Australia, 35 ; India, 36 ; South Africa, 37-9; Home Conditions, 39

Steamship Services, Railway Companies, 310-I 2

Stevenson, Mr. G. A., 338, 339, 344,345

Strikes of Railway Men, IYungary, I57-I62 ; Holland, I62-I65; Victoria, 165-I72 Subsidies on Transport, 361 Switzerland, Reasons for State Purchase, 30: Results of Operation, $102-3$

Tafi Vale Railway Company, 312

Tariffs, Continental, 287-29o 
Tasmania, Financial Results, $77-8$

Tatlow, Mr. J., 336, 337, 344

Taxation, Railways and, Exemptions in U.S.A., 54 ; Amounts Imposed in United Kingdom, 57, 392-3 ; Colonial Railways and Taxation, 84 ; Prussian State Railways, II 1

Telegraph Act, 1868, 30 I

Telegraph Department, 200202

Traders and the Railways, Hope to Secure Reduced Rates, I ; Relations with Railway Companies, 197 ; Grievances, 204 ; Question of Excessive Rates, 218-226; Preferential Rates, 228-231; Equal Mileage Rates, 232-4; Milk Rates, 237-9; Gain from Nationalisation Problematical, 239245; Warehousing and Wharfage, 241 ; Credit, 242 ; German 'Traders' Grievances, 245; Belgian Traders, 249 ; Australian Traders, 249-252; State and Trader in Prussia, 264-5 ; Irish Traders' Grievances, $348-350$; Conditions of Trade, 380-3; Complaints, $384-5$; Question of Combinations, 4I6-420; Attitude towards Railways, 426

Traffic Problems, I86

Train Mileage, Savings in, 388

Tramways, Railwaysand, 314-5

Transvaal. See Central South African Railways.

Trout, Mr. J. M., 54

Twinberrow, Mr. J. D., I72

United States of America, Assistance Given to Companies, 54-5; "Blanket" Rates, 234 ; Position of Rail. ways to.day, 395-6; Railway Trusts, 418

Unremunerative Lines, Victoria, 68, 70, 123 ; Western Australia, 8I ; Cape Colony, 86, 89

VICTORIA, Reasons for Government Action, 35; Financial Results, $66-72$; Provision for Unremunerative Rates, 69 ; Unremunerative Lines, 70-I, 123; Polinical Pressure, 123; Railway Commissioners Appointed, I23 ; Abuses in Appointments and Promotions, 125-7; Railwaymen's Strike, 165-170; Anti-strike Legislation, $170-1$

WAGES, $324-5,387-8,390-I$ Wagon-load Lots, in Germany, 272-4 ; in Denmark, 361

Wagons, Shortage of, in Germany, 115-8; in New South Wales, 25I-2

War Office, 202

Ward, Sir Joseph, 82

Warehousing and Wharfage, 241, 281

Water Transport, Rhine, 257261 ; in Holland, 259

Western Australia, Financial Results, 78 ; Colonial Coal Industry Developed at Cost of Railways, 79 ; ditto, Water Supply, 80 ; Workers' Compensation Act, 8 I

Western of France Company, 29

William I. (Holland), 26

Williams, Mr. F. S., 206

Winter Dairying, 363-4

Working Expenses, Effect of Big Loads, 274-5; Advantages on Continental Railways, $275-6$; Increase of, 394 ; Savings in, through Combination, 396-412

Workmen's Trains, 57,376 


\section{Railway Publications.}

\section{FRENCH RAILWAY .DEYELOPMENT SINCE 1905.}

By Richard Bloch, Traffic Manager, Orleans Railway, A treatise on the recent development and present-day operation of the French railway systems. With 17 maps, diagrams, and other illustrations. Price Is, net.

\section{RAILROAD OPERATIONS. .}

How to Know Them from a Study of the Accounts and Statistics. By J. Shirler Eator, Statistician of the Lehigh Valley Railroad. The object of the book is to enable a railwayman to get the meaning out of statistics of operation. Price 10s. net.

\section{THE FIXING OF RATES AND FARES.}

By H. MARriotT, Goods Manager, Lancashire and Yorkshire Rallway. With an introduction by Professor S. J. Chapman, Dean of the Faculty of Commeree in the Victoria University of Manchester. A concise and practical text-book explaining the system on which British rallway rates and fares are arranged. With numerous diagrams and tables. Price $2 s$. net.

\section{THE RAILWAY GAZETTE.}

It is the leading weekly illustrated journal of railway management, operation and engineering. It is "read wherever there are railways," and is essential to all "thinking" railwaymen. A specimen copy wlil be sent free on application. It is published every Friday, price $6 d$., and is obtainable at all railway bookstalls and newsagents. Inland prepaid subscription rate, $£ 1 \mathrm{l} s$, per anuum ; foreign, $£ 112 s$.

\section{THE FIRST PRINCIPLES OF RAILWAY SIGNALLING.}

By C. B. Brues, Signal Engineer, New South Wales Railways. This book is based. on lectures recently delivered at the Victoria University of Manchester. Though there have been many treatises on railway signalling, most of them are primarily intended for the railway signal engineer. Mr. Byles strikes a new note and fills a "long-felt want" in preparing a simple but painstaking elementary treatise on the first principles of railway signalling. He assumes no knowledge on the part of the reader, and his book should be welcomed by the nembers of the railway signalling schools, which several British railways have recently established. Price $3 s$. net.

\section{RAILWAY OPERATING STATISTICS.}

By C. P. Mossop, Head of Statisties Department, North Fastern Railway. Shows the practical use to which operating statistics can be put, particularly with regard to wagon loads, train loads, freight train costs, warehouse and marshalling yard costs, passenger service and rolling stock. The most suitable revenue and cost units for each operation are given, together with specimen returms and tables, rules for compilation, \&c. Illustrated with numerous charts in colours. Price 2s. 6 $d$. net.

\section{SOUTH AMERICAN RAILWAYS.}

Two Special Numbers recently issued by the Railway Gazette in connection with the Argentine Centenary have been bound together in book form, with over 100 maps and other illustrations. This volume will probably come quite as a revelation to many people at hoine who have only a very indefinite idea as to the railway development in the Latin American States. Price 5s. net.

\section{THE RAILWAY GAZETTE,}

Queen Anne's Chambers, Westminster, London, S.W. 



$$
5
$$




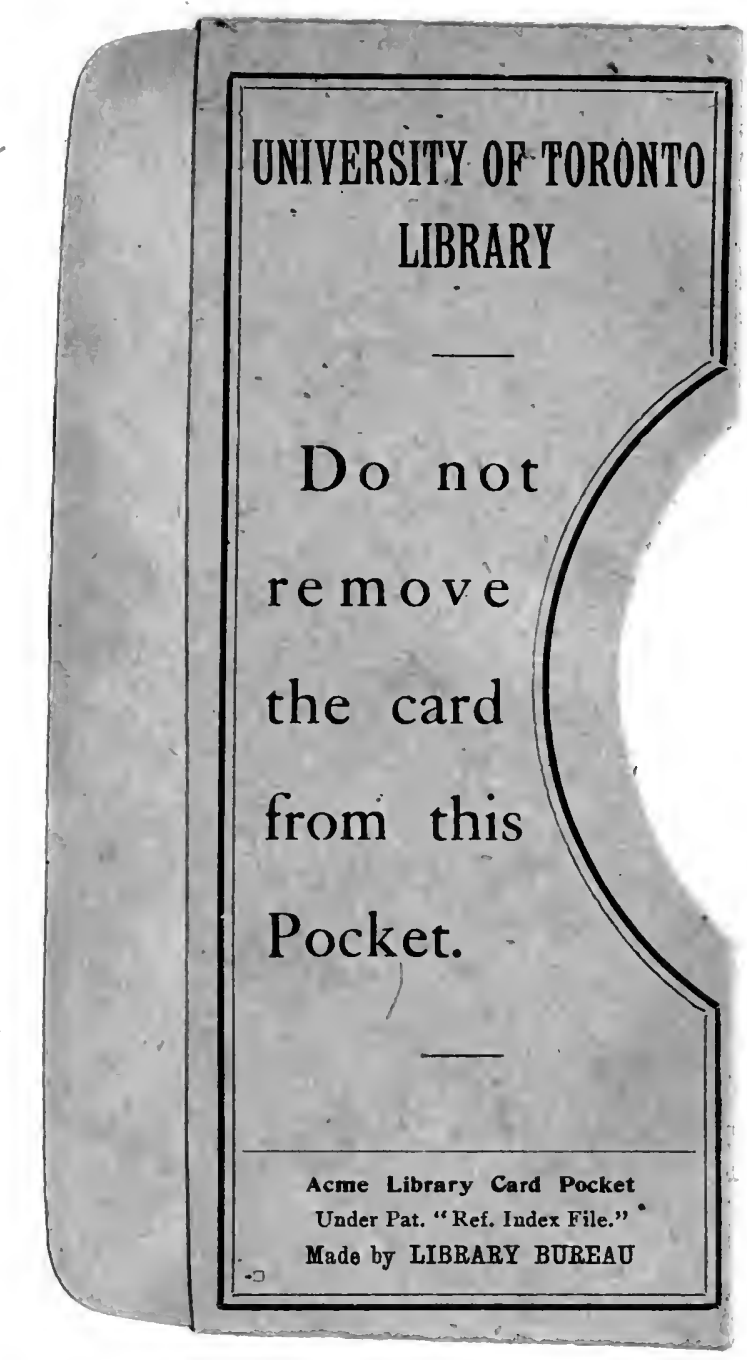


